Ramiro Durán Martínez

\title{
LA LENGUA INGLESA EN LA PUBLICIDAD ESPAÑOLA: UNA APROXIMACIÓN PRAGMÁTICA
}

EDICIONES UNIVERSIDAD DE SALAMANCA 


\section{COLECCIÓN VITOR}

83

$\mathrm{c}$

Ediciones Universidad de Salamanca

y Ramiro Durán Martínez

$1^{a}$ edición: Marzo, 2002

I.S.B.N.: 84-7800-816-0

Depósito Legal: S. 287-2002

Ediciones Universidad de Salamanca

Plaza de San Benito, s/n

37002 Salamanca (España)

Página en internet: http://webeus.usal.es

Correo-e: eus@usal.es

Realización:

Nemática, S.L.

Impreso en España - Printed in Spain

Todos los derechos reservados. Ni la totalidad ni parte de este libro

puede reproducirse ni transmitirse

sin permiso escrito de

Ediciones Universidad de Salamanca

CEP. Servicio de Bibliotecas

\section{DURÁN MARTINEZ, Ramiro}

La lengua inglesa en la publicidad española [Archivo de ordenador] :

Una aproximación pragmática / Ramiro Durán Martínez.-Salamanca:

Ediciones Universidad de Salamanca,2002

1 disco compacto.-(Colección Vitor; 83)

Tesis-Universidad de Salamanca, 2001

1.Universidad de Salamanca (España)- Tesis y disertaciones académicas.

2. Publicidad-España. 3. Publicidad-Lenguaje. 4. Inglés (Lengua).

$659.123(460): 811.111(043.2)$ 


\section{LA LENGUA INGLESA EN LA PUBLICIDAD ESPAÑOLA: UNA APROXIMACIÓN PRAGMÁTICA}

El trabajo que presentamos a continuación tiene como objeto de estudio uno de los rasgos del discurso publicitario. Dentro de las diversas características que la comunicación publicitaria manifiesta nos centraremos en el análisis de los diferentes factores lingüísticos atribuibles al influjo angloamericano en la publicidad española, factores que van desde el continuo uso de anglicismos hasta la utilización de textos escritos en lengua inglesa para promocionar productos dirigidos a un público cuya lengua de uso común es el español.

La situación comunicativa que se produce cuando el emisor envía conscientemente un estímulo lingüístico al destinatario en un idioma que no es de uso habitual buscando conseguir su persuasión es un fenómeno que merece un minucioso análisis. Los modelos del código no han llegado a encontrar una explicación convincente para esta particular situación comunicativa, máxima expresión del actual influjo lingüístico angloamericano en la publicidad española, algo que sí puede obtenerse aplicando los postulados fundamentales de la comunicación inferencial. En este trabajo estudiaremos el fenómeno aquí mencionado siguiendo los principios establecidos por la teoría de la relevancia de Sperber y Wilson (1986). El no tener noticias de la existencia de un estudio sistematizado del tema en cuestión nos ha decidido a dedicarle este trabajo.

Los diversos corpus de anuncios examinados en nuestro trabajo de investigación han sido agrupados en dos apartados principales: el primero dedicado a las ofertas de empleo y el segundo dedicado a la publicidad comercial. Dentro del estudio de la publicidad comercial, a la que prestamos una atención preferente en nuestro trabajo, hemos distinguido dos corpus distintos. El primer análisis se limita a presentar ciertos datos estadísticos sobre la frecuencia con la que diferentes productos publicitarios recurren a la lengua inglesa para comunicarse con un destinatario que bien no la utiliza como código habitual o bien la desconoce por completo mientras que el segundo se dedicará a encontrar las bases teóricas que nos ayuden a comprender las razones que justifican el recurso a una estrategia comunicativa que radica en el uso por parte del emisor de un estímulo lingüístico no esperado por el destinatario. Con ese propósito, analizaremos los 450 anuncios de publicidad comercial que componen nuestro segundo corpus. 
Consideramos que la teoría de la relevancia puede explicar de manera precisa la atracción que hoy en día despierta el uso de la lengua inglesa en los destinatarios de los textos publicitarios. La multiplicidad de factores que concurren en el discurso publicitario puede servir como justificación a la carencia de estudios sobre el asunto en cuestión basados en la aplicación de las teorías lingüísticas que parten de la naturaleza interactiva de todo acto comunicativo. Los postulados de Sperber y Wilson nos han parecido el punto de partida más adecuado para llevarlo a cabo debido, entre otros factores, a la importancia que prestan a la función del destinatario dentro del acto comunicativo publicitario. Los modelos del código, paradigma dominante en el estudio de la comunicación publicitaria en general y en el análisis lingüístico del influjo angloamericano en particular, asignan al destinatario un papel esencialmente pasivo. Sin embargo, cada vez resulta más notorio que el éxito o fracaso de un anuncio depende en gran medida del esfuerzo que éste está dispuesto a hacer para interpretar el mensaje y llegar a las implicaturas perseguidas por el anuncio. En el discurso publicitario las complejas estrategias comunicativas puestas en marcha por el emisor no servirán para nada si el destinatario no decide hacer un esfuerzo para acceder a las implicaturas que caracterizan la comunicación publicitaria. Los particulares condicionantes del fenómeno publicitario contemporáneo, definidos por la imperiosa necesidad de captar la atención de un determinado target, contribuyen a poner de manifiesto la naturaleza interactiva de este particular acto comunicativo.

Como conclusión a esta breve introducción, únicamente resaltar que, como veremos a lo largo de nuestro trabajo, existen multitud de causas a las que se puede aludir a la hora de explicar la penetración anglicista en la sociedad española. No obstante, creemos que en los estudios del tema en cuestión no se ha prestado la suficiente atención a los elementos que condicionan de una u otra manera la fuerza del acto comunicativo publicitario y de forma muy especial, a todos los factores que rodean a la función del destinatario dentro de este particular intercambio comunicativo. Quizás sea conveniente terminar recordando el primer cometido de todo anuncio, que no es otro que atraer la atención del apático destinatario, como bien parece indicar el verbo latino advertere del que se deriva los términos ingleses advertisement, advertise o advertising, etc. 
THE ENGLISH LANGUAGE IN SPANISH ADVERTISING: A PRAGMATIC APPROACH

The subject under study in the work that follows is one of the features of the discourse of advertising. Of the various characteristics shown by advertising communication, we shall concentrate on the analysis of the different linguistic factors attributable to AngloAmerican influence on Spanish advertising: these factors range from the continual use of anglicisms to the use of texts written in English to promote products aimed at a general public whose everyday language is Spanish.

The communicative situation produced when the sender consciously sends, as a persuasive ploy, a linguistic stimulus to the receiver in a language which is not its own is a phenomenon which calls for minute analysis. The code models have not managed to find a convincing reason for this particular communicative situation, which is current AngloAmerican influence in Spanish advertising at its greatest, but an explanation can be reached by applying the basic arguments of inferential communication. In this study we will look at the phenomenon mentioned here according to the principles established by Sperber and Wilson's Relevance Theory (1986). We are unaware of any other systematic study of this topic and have therefore decided to devote this work to the subject.

The various corpuses of advertisements examined in this piece of research have been put into two main sections: the first is devoted to job offers and the second to product advertisements. Within the study of product advertisements, which receives special attention in this work, we have made a distinction between two separate corpuses. The first analysis is limited to presenting certain statistical data on the frequency with which different advertising products resort to the English language in order to communicate to a receiver although the receiver either does not use English as a customary code or is totally ignorant of the language; the second is devoted to finding theoretical bases to help us to understand the reasons behind resorting to a communicative strategy based on the sender using a linguistic stimulus unexpected by the receiver. With this in mind, we will analyse the 450 product advertisements which make up our second corpus. 
We consider that Relevance Theory can explain in an exact fashion the attraction the use of the English language has these days for the receivers of advertising texts. The multiplicity of factors coming together in advertising discourse could be the reason for the lack of studies on this topic based on the application of linguistic theories that take the interactive nature of every communicative act as a starting point. The basic arguments of Sperber and Wilson seem to us the most appropriate starting point in order to carry this out given, among other factors, the importance they grant to the function of the receiver within the communicative advertising act. The code models, which are the dominant paradigm in the study of communicative advertising in general and in the linguistic analysis of Anglo-American influence in particular, give the receiver an essentially passive role. However, it is more and more evident that the success or failure of an advertisement depends to a great extent on the effort the receiver is prepared to make in order to interpret the message and arrive at the implicatures sought by the advertisement. In advertising discourse the complex communicative strategies set in motion by the sender will be of no use whatsoever if the receiver does not make the effort to gain access to the implicatures which are characteristic of advertising communication. The particular determining factors of the contemporary advertising phenomenon, defined by the pressing need to catch the attention of a specific target, contribute to highlighting the interactive nature of this particular communicative act.

In conclusion to this brief introduction, we would just stress that, as we shall see throughout our study, there are a multitude of causes which can be referred to when explaining the degree of penetration of the English language in Spanish society. Even so, we believe that in studies of the topic in question sufficient attention has not yet been paid either to the elements which condition in one way or another the advertising communicative act, or specifically to all the factors which surround the function of the receiver within this particular communicative exchange. Perhaps we should finish by remembering the first aim of every advertisement, which is none other than to attract the attention of the apathetic receiver, just as the Latin verb advertere, from which the English terms advertisement, advertise or advertising derive, seems to indicate. 


\section{ÍNDICE DE CONTENIDOS}

\section{LA LENGUA INGLESA EN ESPAÑA: LA CUESTIÓN DE LOS ANGLICISMOS}

\section{1.- INFLUJOS SUFRIDOS POR LA LENGUA ESPAÑOLA A TRAVÉS}

DE SU HISTORIA

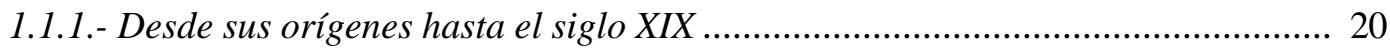

1.1.2.- El siglo XX: la cuestión de los anglicismos....................................................... 25

1.2.- LA LENGUA INGLESA EN EL SIGLO XX.......................................................... 27

1.2.1.- La expansión de la lengua inglesa................................................................... 27

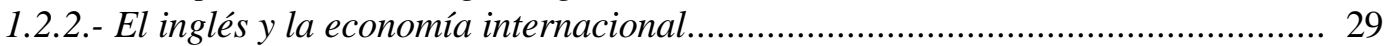

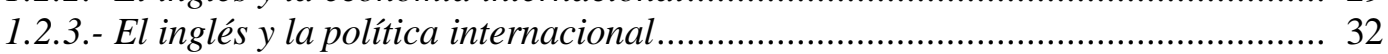

1.2.4.- Situación actual del inglés en el mundo......................................................... 33

1.3.- LA INFLUENCIA ANGLOAMERICANA EN EL ESPAÑOL MODERNO ............. 36

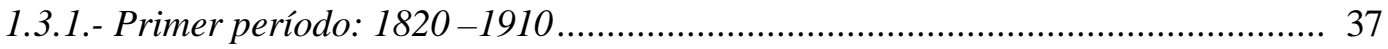

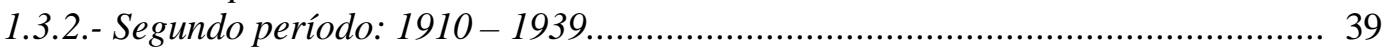

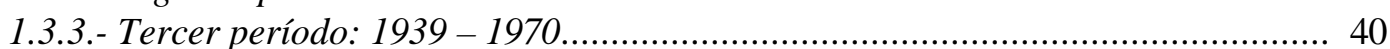

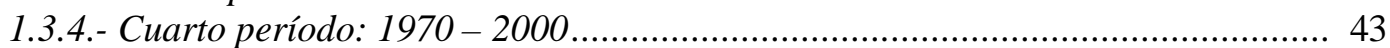

1.4.- DIFERENTES POSTURAS SOBRE LA ANGLOMANÍA Y LOS ANGLICISMOS.... 45

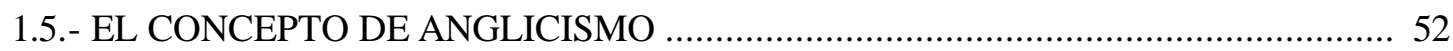

1.5.1.- Clasificación del anglicismo léxico .................................................................... 55

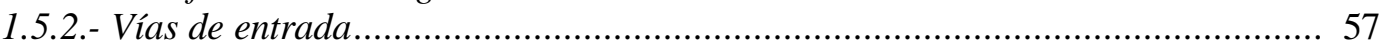

1.5.3.- Campos léxicos más proclives al anglicismo ..................................................... 59

1.6.- EL INGLÉS EN LA PUBLICIDAD ESPAÑOLA................................................. 61

1.6.1.- El surgimiento de la publicidad moderna ......................................................... 61

1.6.2.- La publicidad en el siglo XX: el dominio de los Estados Unidos........................ 63

1.6.3.- Razones para la penetración anglicista en la publicidad española ..................... 65

1.6.3.1.- Aspiración hacia un marketing y publicidad global ........................... 66

1.6.3.2.- Preferencia de los hablantes hispanos por lo anglosajón ..................... 68

1.6.3.3.- Afán de originalidad en el texto publicitario ..................................... 71

1.7.- PRESENCIA DE LA LENGUA INGLESA EN LA PUBLICIDAD ESPAÑOLA ...... 74 
1.7.1.- Objetivo de nuestro análisis

1.7.2.- El inglés y el anglicismo en las ofertas de empleo ............................................ 75

1.7.2.1.- Anglicismos en las ofertas de empleo............................................ 76

1.7.2.2.- Ofertas de empleo íntegramente escritas en la lengua inglesa ............. 85

1.7.3.- El inglés en la publicidad comercial.................................................................. 97

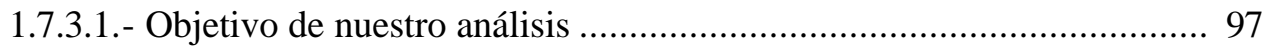

1.7.3.2.- Anuncios de cosméticos...................................................................... 98

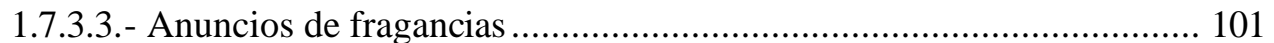

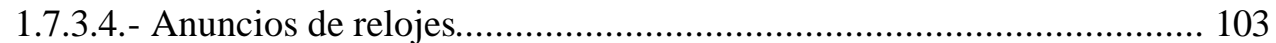

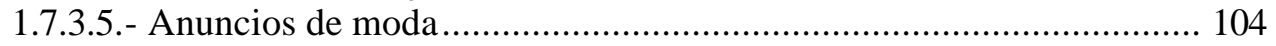

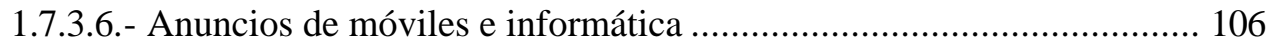

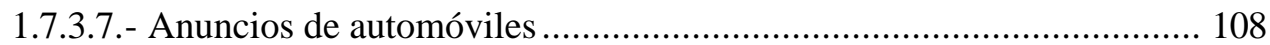

1.7.3.8.- Anuncios de bebidas .......................................................................... 109

1.7.3.9.- Anuncios de tabaco............................................................................ 111

1.7.4.- Conclusiones estadísticas de nuestro estudio................................................. 113

\section{MODELOS DE ANÁLISIS LINGÜÍSTICO APLICADOS A LA COMUNICACIÓN PUBLICITARIA.}

2.1.1.- El modelo comunicativo de la teoría matemática de la información .................. 117

2.1.2.- El modelo de Lyons....................................................................................... 119

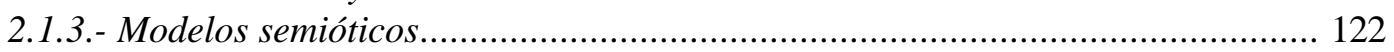

2.2.- EL MODELO DEL CÓDIGO EN LA COMUNICACIÓN PUBLICITARIA ............. 124

2.3.- ALGUNOS PROBLEMAS DEL MODELO DEL CÓDIGO …................................. 127

2.4.- ANÁLISIS DEL MODELO SEMIÓTICO DE BARTHES APLICADO A UN ANUNCIO PUBLICITARIO ........................................................ 131

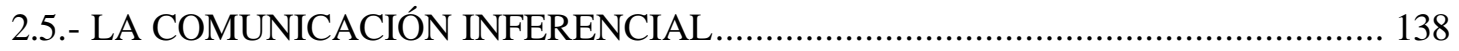

2.5.1.- El modelo del código frente al modelo inferencial ........................................... 138

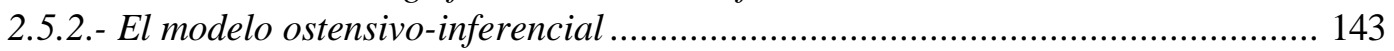

2.5.3.- La teoría de la relevancia y la comunicación ....................................................... 145

2.5.3.1.- El entorno cognitivo .................................................................... 146

2.5.3.2.- Implicaciones contextuales ............................................................ 147

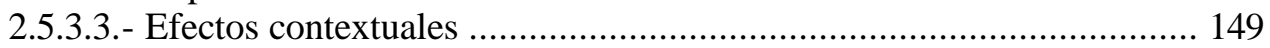

2.6.- DEFINICIÓN DE LA TEORÍA DE LA RELEVANCIA............................................. 151

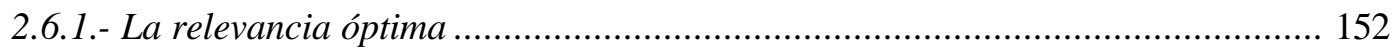

2.6.2.- Principios de la teoría de la relevancia .......................................................... 152

2.7.- PUBLICIDAD Y TEORÍA DE LA RELEVANCIA................................................. 154

2.7.1.- La naturaleza del acto comunicativo publicitario ............................................ 156 
2.7.2.1.- La cooperación entre emisor y receptor

2.7.2.2.- Definición de comunicación encubierta............................................ 159

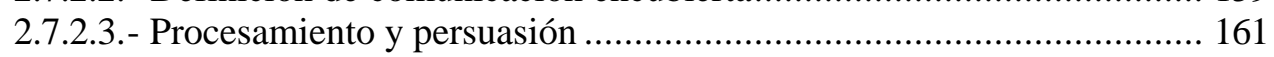

2.7.2.4.- La implicación del receptor................................................................ 162

2.7.3.- Análisis de las implicaturas en un anuncio publicitario.

\section{PRESENCIA DE LA LENGUA INGLESA EN LA PUBLICIDAD ESPAÑOLA: ANÁLISIS LINGÜÍSTICO DEL CORPUS}

3.1.- ESTADO DE LA CUESTIÓN.

3.1.1.- El análisis tradicional basado en el modelo del código 172

3.1.2.- El análisis basado en la teoría de la relevancia.

3.1.2.1.- La lengua inglesa como técnica de captación de atención.................. 176

3.1.2.2.- La búsqueda de la complicidad con el destinatario ............................ 178

3.1.2.3.- El comportamiento comunicativo relevante.................................... 180

3.1.2.4.- Las propiedades del estímulo ............................................................ 180

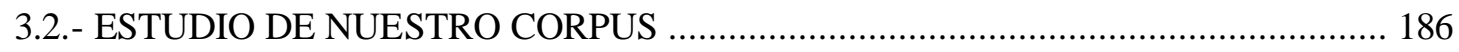

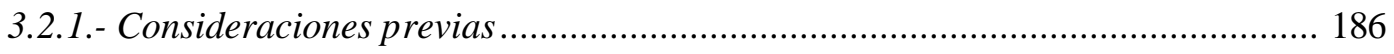

3.2.1.1.- Delimitación del corpus .................................................................... 186

3.2.1.2.- Anuncios tradicionales y anuncios de imagen de marca..................... 189

3.2.1.3.- Estructuración tripartita de los anuncios en prensa............................. 193

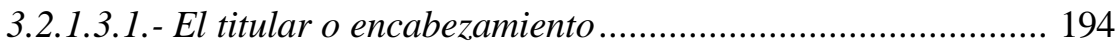

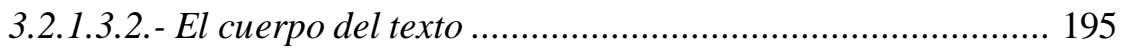

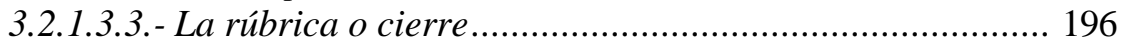

3.2.2.- La lengua inglesa en productos anunciados utilizando ambas técnicas.............. 198

3.2.2.1.- Anuncios de cosméticos.................................................................... 198

3.2.2.1.1.- Anuncios que siguen la estructuración tripartita.............. 199

3.2.2.1.2.- Anuncios que no siguen la estructuración tripartita......... 213

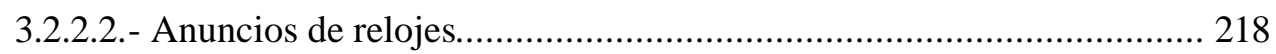

3.2.2.2.1.- Anuncios que siguen la estructuración tripartita.............. 219

3.2.2.2.2.- Anuncios que no siguen la estructuración tripartita.......... 226

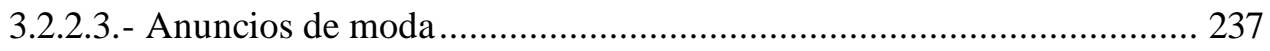

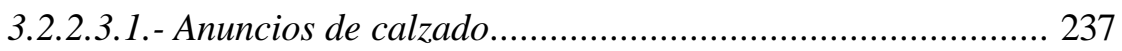

3.2.2.3.1.1.- Anuncios que siguen la estructuración tripartita.......238

3.2.2.3.1.2.- Anuncios que no siguen la estructuración tripartita. 242

3.2.2.3.2.- Anuncios de ropa ........................................................ 252

3.2.2.3.2.1.- Anuncios que siguen estructuración tripartita............252

3.2.2.3.2.2.- Anuncios que no siguen estructuración tripartita.... 261 
3.2.2.4.- Aspectos más relevantes de la presencia de la lengua inglesa en productos publicitados utilizando ambas técnicas ....

3.2.3.- La lengua inglesa en productos publicitados utilizando estructuración tripartita... 275

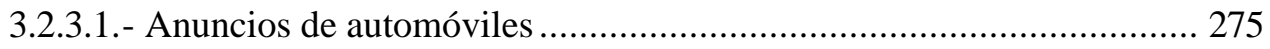

3.2.3.2.- Anuncios de teléfonos móviles e informática .................................... 277

3.2.3.3.- Aspectos más relevantes de la presencia de la lengua

inglesa en productos publicitados utilizando la estructuración tripartita........... 285

3.2.4.- La lengua inglesa en productos publicitados utilizando la técnica de imagen de marca

3.2.4.1.- Anuncios de bebidas

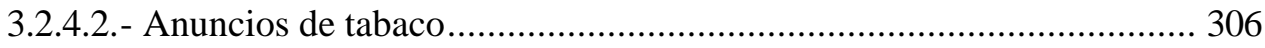

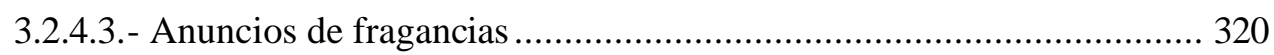

3.2.4.4.- Aspectos más relevantes de la presencia de la lengua inglesa en productos publicitados utilizando la imagen de marca.

4. CONCLUSIONES 


\section{INTRODUCCIÓN}

La abrumadora presencia de anuncios publicitarios en numerosos ámbitos de nuestra vida cotidiana es fácilmente apreciable para cualquier ciudadano medio, acostumbrado a recibir una avalancha de invitaciones que, aunque en principio, sólo parecen buscar su participación en un acto comunicativo persiguen un objetivo muy concreto: influir en su conducta respecto a la percepción de un determinado producto. La publicidad se ha convertido en "part of the wallpaper of our lives" (Byrne 1992: 4). Cardona y Berasate (1972: 22) en un libro pionero dentro del lenguaje de la publicidad en España, destacaban su abundancia afirmando que ya en los años setenta "más de la mitad de lo que se imprime en sus diversas formas es publicidad, y en un año, la producción de la publicidad impresa sobrepasa cuantitativamente la producción novelística de un siglo entero.”

El reconocimiento generalizado de este hecho no ha venido acompañado por un análisis en profundidad del acto comunicativo publicitario desde los campos directamente relacionados con la comunicación humana. Así, podríamos hablar de una cierta falta de consideración en el mundo intelectual por el fenómeno publicitario posiblemente debida a los objetivos prácticos que persigue: vender un producto o servicio. Sin embargo, la publicidad tiene una serie de características que desde nuestro punto de vista la hacen merecedora de estudio y que pasamos a mencionar a continuación.

Una campaña publicitaria acertada genera enormes beneficios económicos para una empresa, como recuerdan insistentemente los manuales de publicidad, pródigos en ejemplos que atribuyen el éxito o fracaso de un determinado producto a una afortunada o desafortunada campaña de promoción. La ingente cantidad de dinero que está en juego la convierte en una actividad altamente remunerada en la que actúa un conjunto de equipos de personas marcadamente profesionalizados: director creativo, redactores, director artístico, ejecutivos, investigadores de mercados, coordinadores de medios, director general, etc. 
Además, las agencias publicitarias, ayudadas por su disponibilidad económica, pueden mantenerse en contacto permanente con la realidad social del momento y para ello no dudan en elaborar exhaustivos planes de marketing donde se estudia, en términos estadísticos, la segmentación de los diversos mercados. El perfil demográfico, los diferentes estilos de vida, las disponibilidades económicas o el propósito de buscar bien una venta inmediata bien una venta futura definen las estrategias que el publicista utiliza para llegar a los diferentes grupos de consumidores.

Ya hemos destacado que el primer propósito de toda campaña publicitaria consiste en establecer una comunicación con sus destinatarios. Joaquín Lorente, ilustre publicista, afirma lo siguiente: "Cada día nuestro cerebro percibe miles de comunicaciones, registra unas centenas y archiva unas docenas. En cada grupo, existen comunicaciones que son publicitarias" (1986: 37). Por la propia naturaleza de este particular acto comunicativo, los condicionantes que rodean el trabajo del publicista no ayudan a que la comunicación publicitaria se produzca de manera sencilla: los anuncios se sitúan en "la periferia de nuestra atención", existen muchos productos y muchos anuncios similares, el espacio del que disponen en los diferentes medios de comunicación es caro y limitado, el destinatario es reticente a participar en el acto comunicativo por conocer de antemano su cometido final, etc. Todos estos factores contribuyen, desde nuestro punto de vista, a dar mayor mérito a una comunicación publicitaria satisfactoria ya que los publicistas, en especial los creativos y los redactores, demuestran ser expertos conocedores de los factores que condicionan la comunicación humana, valorando en gran medida la fuerza del lenguaje para romper las barreras existentes entre el emisor y el destinatario del anuncio.

Hoy en día asistimos a un constante desarrollo de los medios de comunicación siendo sus efectos muy destacados en nuestras vidas. La publicidad es uno de los medios de comunicación de masas que acrecienta su presencia en nuestra sociedad con mayor fuerza y actualmente es un elemento imprescindible no sólo para la propia existencia de otros medios - la principal vía de financiación de la mayor parte de la prensa y de las cadenas de radio y televisión es la publicitaria - sino que es parte imprescindible para el buen funcionamiento de nuestro sistema económico: su función de animar al consumo es a menudo comparada con la función del aceite que posibilita que un motor funcione correctamente. 
Pero no todas las consecuencias de la publicidad pueden valorarse de forma tan positiva: su omnipresencia y sus sofisticadas técnicas ejercen a veces una influencia demasiado opresiva, principalmente sobre cierto tipo de receptores que por distintas razones son más vulnerables. Esta presión es una fuente de serios problemas de muy diversa índole: psicológicos, sociales, económicos, etc. Además, de todos es sabido que la publicidad llega a crear modas, gustos, e incluso valores, que no siempre tienen como objetivo hacer coincidir la venta del producto con el bienestar del receptor.

El acto comunicativo publicitario se puede caracterizar por dos condicionantes: la clara naturaleza asimétrica de la comunicación que se establece entre emisor y destinatario y su carácter intencional. En primer lugar, debemos destacar que el equipo de especialistas que crea un texto publicitario tiene un conocimiento exhaustivo de todas las fórmulas posibles para condicionar el comportamiento del destinatario mientras que éste desconoce buena parte de ellas. Además, la intencionalidad debe ser siempre tenida en cuenta a la hora de llevar a cabo el estudio de la comunicación publicitaria. No debemos olvidar que se trata de un mensaje pagado con una dimensión pragmática muy clara. Ésta es la de influir en la conducta de los receptores:

El acto de comunicación de la publicidad nace movido por el interés económico, o dicho de otra manera, tiene una dimensión pragmática: la persuasión ejercida por el emisor está orientada a influir en la conducta de los receptores. (Ferraz 1993: 12)

El fenómeno publicitario está totalmente condicionado por el imperativo último de la persuasión del receptor y la eficacia de la persuasión estará directamente relacionada con la premisa relativa a la asimetría del proceso de comunicación ya que cuanto más consciente sea el receptor de las circunstancias que rodean el mensaje publicitario y de las diferentes técnicas que utiliza para conseguir su persuasión, mayores dificultades tendrá éste para persuadirle.

La publicidad seduce y fascina mediante técnicas cada vez más sofisticadas y consecuentemente resulta difícil abstraerse a esa fascinación: todo estudio que ayude al destinatario a evitar ese estado de embelesamiento y posibilite ver los anuncios desde una perspectiva racional contribuirá a una valoración de ellos más crítica y disminuirá su capacidad de atracción. Como no está en nuestras manos el decidir sobre la existencia o 
las funciones de la publicidad, el único camino que nos queda para defendernos de sus posibles efectos negativos es profundizar en su conocimiento.

El trabajo que nos disponemos a presentar a continuación tiene como objeto de estudio uno de los rasgos del acto comunicativo que se produce entre el emisor de un anuncio y sus destinatarios. Dentro de las diversas facetas presentes en el acto comunicativo publicitario nos centraremos en el análisis de los diferentes factores lingüísticos atribuibles al influjo angloamericano en la publicidad española, factores que van desde el continuo uso de anglicismos hasta la utilización de mensajes escritos en lengua inglesa para publicitar productos dirigidos a un público cuya lengua de uso común es el español ${ }^{1}$. La situación comunicativa que se produce cuando el emisor envía conscientemente un estímulo lingüístico al destinatario en un idioma que no es de uso habitual buscando conseguir su persuasión es un fenómeno que merece una minuciosa consideración. Los modelos del código no han llegado a encontrar una explicación convincente para esta particular situación comunicativa, algo que sí puede conseguirse aplicando los postulados fundamentales de la comunicación inferencial. En este trabajo estudiaremos el fenómeno que hemos mencionado siguiendo los principios establecidos por la teoría de la relevancia de Sperber y Wilson, formulada por primera vez en el año 1986 en el libro Relevance. Communication and Cognition. El no tener noticias de la existencia de un estudio sistematizado del tema en cuestión nos ha decidido a dedicarle este trabajo.

La particular situación comunicativa que nos ocupa en este trabajo de investigación no responde únicamente a factores de naturaleza lingüística ya que también obedece a diversos condicionantes de muy distinta índole: económica, política, social, cultural, etc. En primer lugar debemos destacar que el influjo angloamericano no es único de la publicidad española ya que también ocurre, con mayor o menor profusión, en todos los idiomas del mundo occidental. Francia ha sido el país donde se ha llevado a cabo un mayor debate sobre el tema en cuestión llegándose incluso a promulgar leyes que perseguían la eliminación de los anglicismos en las comunicaciones públicas (véase Lorenzo 1996: 16 o Riquelme 1998: 141). Moncada (1995: 257) señala que "la

\footnotetext{
${ }^{1}$ A lo largo de este trabajo haremos uso del término español, y no castellano, para establecer un contraste claro entre el uso de este idioma y el uso de la lengua inglesa. En ningún caso es nuestra intención ignorar la existencia de otras lenguas - gallego, euskera y catalán - cooficiales en diversas áreas de nuestra geografía y ampliamente utilizadas por sus hablantes, aunque poco frecuentes en el mundo publicitario.
} 
negociación francesa en el GATT ha ido acompañada por una ley nacional contra los anglicismos en los carteles públicos, parte de la cual fue retirada por ridícula.”

El influjo lingüístico angloamericano en las culturas occidentales es principalmente una consecuencia directa de factores macroeconómicos. En los últimos años hemos asistido a una creciente expansión de las grandes empresas multinacionales debido a los cambios políticos, mediáticos, sociales, tecnológicos, etc. que han posibilitado el surgimiento de una economía global. Las estrategias de marketing de las grandes empresas ya no se dirigen a un país determinado sino que se llevan a cabo considerando las áreas a las que se destinan: Norteamérica, Europa, Asia, Iberoamérica, etc. La Unión Europea, a la que España pertenece desde 1986 se ha convertido en un único mercado y a pesar de las significativas diferencias entre los países que la componen, sus habitantes muestran unas pautas de comportamiento cada vez más uniformes ${ }^{2}$.

Las empresas multinacionales, conscientes de los costes que se ahorrarían dirigiendo sus productos a un mercado pan-europeo, impulsan decididamente esa integración y para este propósito cuentan con la inestimable ayuda de los medios de comunicación de masas. Las grandes compañías publicitarias no son ajenas a esta tendencia general y ya operan siguiendo los anteriores criterios. Las campañas dirigidas a distintos países europeos, denominadas en el argot publicitario cuentas multinacionales, se centralizan en una gran ciudad - Londres o París principalmente - que es donde se ubica la agencia central de la compañía. Allí se crean las diferentes campañas que después se adaptarán, en mayor o menor medida, a los distintos países de la Unión ${ }^{3}$. En este proceso de adaptación ya entran en juego las filiales de las agencias en los países donde

\footnotetext{
${ }^{2}$ De Mooij alude al hecho de que los ciudadanos europeos tienden a manifestar unas necesidades, gustos, estilos de vida y hábitos de consumo similares, aunque todavía existen diferencias importantes, muchas de las cuales tienen que ver con los distintos idiomas existentes en este espacio económico: "A single advertising campaign, run throughout Europe, would miss its target: 66 per cent of all EC citizens speak only one language; less than 25 per cent speak two, while only 8 per cent are trilingual. Europeans do not display homogeneous buying behaviour. National aspects of buying behaviour will not disappear inmediately with the abolition of national borders" (1991: 29).

${ }^{3}$ Ogilvy (1984: 61) destaca que agencias publicitarias como J. Walter Thompson, McCann Erickson o Young and Rubicam establecieron sus cadenas internacionales para satisfacer las necesidades de empresas multinacionales como General Motors, Coca-Cola, Esso o General Foods.
} 
se emitirá o publicará el anuncio, que participan de forma activa en la adecuación del mensaje a las condiciones específicas de cada país.

Las agencias publicitarias tienen presente, desde el comienzo de su trabajo, el ámbito al que se dirigen sus campañas. Así, cuando pretenden elaborar un anuncio destinado a diferentes países tratan de utilizar estrategias que bien funcionen correctamente en todos ellos o bien que sean fáciles de ajustar. La mayor parte de los anuncios únicamente adaptan su contenido lingüístico:

When planning a campaign for several areas each with a different language, this must be taken into account from the very beginning. It is best to avoid playing with words and using colloquialisms, and to keep the message simple, short and direct. On the other hand, it is important not to make the message so bland that it becomes boring. (De Mooij 1991: 179)

Al elaborar una campaña publicitaria susceptible de ser utilizada en diferentes países europeos normalmente se comienza con la redacción de un anuncio en lengua inglesa ${ }^{4}$ por constituir este idioma la lingua franca tanto de las diferentes naciones que integran la Unión Europea como del mundo publicitario (véase De Mooij 1991: 5 o Crystal 1997: 87). El inglés es el idioma que se toma como punto de partida ya que además posibilita una comunicación fluida entre las diferentes filiales de las agencias publicitarias. Como ya hemos dicho anteriormente la mayoría de los anuncios presentan una adaptación de sus contenidos lingüísticos al idioma propio de cada país pero cuando eso no ocurre y la agencia decide mantener todo o parte del anuncio en lengua inglesa, se debe a una decisión cuidadosamente sopesada. Todos los elementos existentes en un anuncio publicitario desempeñan un cometido determinado ya que no debemos olvidar que la elaboración de un anuncio es comparativamente mucho más barata que su publicación o emisión en su soporte habitual: televisión, radio, revistas, periódicos, etc.

Podemos observar que, hoy en día, existe un buen número de anuncios, tanto en prensa como en televisión, que reducen al mínimo su contenido lingüístico. Esta técnica, muy común en la promoción de productos ya consolidados en el mercado y de naturaleza poco informativa como las fragancias, las bebidas alcohólicas o el tabaco, ahorra muchos 
costes a las compañías publicitarias multinacionales ya que el esfuerzo de adaptación del anuncio es mínimo.

Una vez esbozadas diferentes pautas de funcionamiento de las agencias publicitarias multinacionales relativas a la producción de anuncios dirigidos a distintos países pasamos a presentar los tres apartados que componen nuestro trabajo. El primero de ellos comienza analizando los influjos sufridos por la lengua española a través de su historia.

El uso de un idioma común siempre ha sido considerado como una de las principales marcas de identidad de una determinada comunidad. No obstante, las particulares lenguas de cada pueblo han sido testigos de excepción de los avatares históricos sufridos por las sociedades que las utilizan. Nadie pone en duda que el influjo de unas lenguas sobre otras es una consecuencia directa de los contactos existentes en las distintas sociedades del planeta. Sin embargo, el reflejo de esos contactos en el idioma ha recibido muy diversas consideraciones dependiendo de la perspectiva adoptada. Así, podemos encontrar desde posiciones puristas que rechazan cualquier tipo de influencia foránea en un idioma hasta perspectivas ultraliberales que aceptan todo préstamo que sea utilizado por los hablantes.

El principal propósito de este primer apartado consiste en analizar el actual influjo lingüístico del inglés en el idioma español destacando el caso relativo a la publicidad que se utiliza en nuestro país. Consideramos que tanto para entender este fenómeno como para adoptar una postura ecuánime ante tal influjo debemos comenzar llevando a cabo un breve recorrido por la historia de la lengua española ya que ello nos ayudará a valorar la situación con mayor rigor, contraponiendo las posturas que hacen hincapié en la identidad propia de cada idioma con las perspectivas que justifican este influjo aludiendo a los condicionantes sociales de cada momento histórico. Después de revisar la expansión y el papel de la lengua inglesa como lingua franca del siglo XX, pasaremos a estudiar la influencia angloamericana en el español moderno y la controvertida cuestión de los anglicismos. El análisis de los préstamos procedentes del inglés - tipología, vías de entrada y campos éxicos más proclives a sufrir este influjo - desembocará en nuestro principal tema de estudio: la presencia de la lengua inglesa en la publicidad española.

\footnotetext{
${ }^{4}$ Esta información ha sido obtenida mediante comunicación personal con Marisa Vazquez, responsable en España de diferentes cuentas multinacionales de la agencia publicitaria Rui Nicoli.
} 
Una vez destacado el dominio de los Estados Unidos en la publicidad moderna estaremos en condiciones de establecer ciertos criterios que expliquen la penetración anglicista en la publicidad española: aspiración hacia un marketing y una publicidad global, preferencia de los hablantes por lo anglosajón y afán de originalidad del discurso publicitario. Concluiremos el primer apartado de nuestro trabajo con un análisis de diversos anuncios recientemente publicados en la prensa española que han sido agrupados en dos apartados: el primero dedicado a las ofertas de empleo y el segundo dedicado a la publicidad comercial.

En el primer apartado hemos distinguido entre las ofertas de empleo que recurren a anglicismos crudos y las que se redactan íntegramente en lengua inglesa buscando, en ambos casos, la función que desempeñan tanto los anglicismos en la estructuración global del texto publicitario como las ofertas de empleo redactadas en inglés dentro de un suplemento de negocios escrito en español. Nuestro primer análisis del uso de la lengua inglesa en la publicidad comercial se limitará a presentar ciertos datos estadísticos sobre el número de anuncios que recurren, en todo o en parte de éste, a la lengua inglesa para comunicarse con un destinatario que bien no la utiliza como código habitual o bien la desconoce por completo. Las conclusiones de este análisis nos darán una idea clara de la magnitud del fenómeno que estamos estudiando.

El segundo apartado, titulado modelos de análisis lingüístico aplicados a la comunicación publicitaria, parte de la revisión de los diferentes modelos del código propuestos para el estudio de la comunicación publicitaria prestando una especial atención a los trabajos de Barthes sobre el tema en cuestión. Los modelos del código han constituído el paradigma dominante en los estudios lingüísticos aplicados al ámbito publicitario y todos ellos parten de la premisa de que todo proceso comunicativo se lleva a cabo mediante un procedimiento de codificación-descodificación. Estos planteamientos, más basados en el estudio del texto ${ }^{5}$ en sí que en el proceso comunicativo que ocurre entre emisor y destinatario, no han podido encontrar una explicación satisfactoria a preguntas como la función del contexto en la interpretación de los anuncios, la negociación que se produce entre emisor y destinatario, la fuerza de los textos

\footnotetext{
${ }^{5}$ Los trabajos relativos a la comunicación humana tienen el texto como principal objeto de estudio. El texto, que no es de una naturaleza exclusivamente lingüística, puede definirse como lo que ocurre entre los participantes en un acto comunicativo. En la comunicación publicitaria los anuncios deben considerarse como textos (véase Vestergaard y Schroder 1985: 14).
} 
publicitarios, el papel y disposición del receptor ante este particular acto comunicativo, etc. La comunicación inferencial, y concretamente la teoría de la relevancia, dan una respuesta satisfactoria a las anteriores preguntas y constituyen el marco más adecuado para estudiar la comunicación publicitaria y más concretamente el uso de mensajes escritos en inglés dirigidos a un público que no utiliza ese idioma como lengua habitual. Concluiremos ese apartado revisando los principales postulados de la teoría de la relevancia y su aplicación al acto comunicativo publicitario, prestando una especial atención a los factores que definen la comunicación encubierta.

Dedicaremos el tercer apartado de nuestro trabajo a llevar a cabo el análisis de la presencia de la lengua inglesa en los anuncios que componen nuestro corpus atendiendo a los principios de la teoría de la relevancia con el objetivo último de valorar el cometido que el inglés desempeña en los anuncios publicados en la prensa española. Para ello hemos establecido tres grandes grupos: productos que recurren a la estructuración tripartita, productos que utilizan la técnica de la imagen de marca y los productos que se publicitan utilizando ambas técnicas. Aunque esta clasificación no posee un carácter estricto, nos resultará muy útil para llevar a cabo nuestro objetivo.

Por último, debemos mencionar que hemos decidido trabajar con anuncios publicitarios en prensa debido a que en ellos sólo tenemos dos componentes a estudiar: la imagen y el texto. Además son más fáciles de reproducir en un medio impreso por la ausencia de sonido y de movilidad en la imagen. 


\section{LA LENGUA INGLESA EN ESPAÑA: LA CUESTIÓN DE LOS ANGLICISMOS}

\section{1. - INFLUJOS SUFRIDOS POR LA LENGUA ESPAÑOLA A TRAVÉS DE SU HISTORIA}

\subsection{1. - Desde sus orígenes hasta el siglo XIX}

Nunca llegaremos a saber con precisión la época exacta en la que el romance castellano comienza su andadura por la Península Ibérica ${ }^{6}$. Como el resto de sus lenguas hermanas, el castellano se forma a partir de la acumulación de diferencias que progresivamente van definiendo su carácter propio y que, a su vez, contrastan con la evolución sufrida por otros idiomas en distintas zonas de la Península Ibérica. Según los datos que poseemos hoy en día sabemos que el romance castellano es ya una realidad en el siglo décimo después de Cristo, cuando los monjes del monasterio de Silos sienten la necesidad de "traducir" expresiones latinas como, por ejemplo, usque in finem, por su equivalente romance "ata que mueran". Surgen entonces los primeros testimonios del romance castellano escrito ${ }^{7}$ pero, aunque no conservamos datos, podemos suponer sin miedo a equivocarnos que la lengua hablada ya llevaba varios siglos existiendo.

\footnotetext{
${ }^{6}$ Cano Aguilar (1995: 24) sitúa el surgimiento del romance castellano en un período que va desde el siglo IV o V después de Cristo al IX o X.

${ }^{7}$ Nos referimos a testimonios escritos conservados. Lapesa (1980: 163) afirma que las Glosas Silenses no son el primer intento de escritura en romance ya que para su composición los monjes utilizaron una especie de diccionario latino-romance no conservado.
} 
El lento surgimiento de las diferentes lenguas romances existentes en Europa se ve acelerado a partir del siglo III por el declive cultural, político y militar del mundo romano. Pasamos a formular aquí una pregunta que consideramos fundamental y que ha sido conscientemente ignorada en el primer párrafo de este apartado: ¿Cómo se había expandido el latín por la Península Ibérica? Sabemos que esta lengua no era autóctona de Hispania ya que se trataba del idioma oficial del imperio romano.

Lapesa (1980: 53) considera que la Península Ibérica comienza a incorporarse definitivamente al mundo grecolatino a partir de la segunda guerra púnica. La conquista romana, iniciada en el 218 A.C. y completada por Augusto en el 19 A.C. al conseguir dominar a cántabros y astures, trae consigo una completa transformación de las sociedades que habitaban Hispania: se introduce el derecho romano, se transforman las técnicas agrícolas, el vestir y las constumbres, se llevan a cabo importantes obras públicas, se establece una nueva administración, etc. La civilización romana también trae consigo su propio idioma que nunca se llegó a imponer mediante el uso de la fuerza pero que enraizó con firmeza en la península debido a las circunstancias históricas del momento. Cano Aguilar incluye el proceso de difusión del latín dentro de lo que denomina la romanización cultural de la península:

Debió de ser un proceso lento, subsecuente a la dominación política: no hubo imposición por parte de Roma, pero los hispanos comprendieron en seguida las ventajas de hablar latín, de forma que, primero los príncipes y la aristocracia indígena y luego todos sus súbditos, lo fueron aprendiendo; al principio, como lengua para hablar con los nuevos señores; luego como lengua de la cultura, el comercio y la política; y luego, por fin, como la única lengua, también de la familia y de las labores diarias. (1995: 25)

Este hecho muestra cómo ya desde los albores del romance castellano la influencia de idiomas en principio ajenos a la Península Ibérica condicionan de una manera decisiva el proceso histórico que irá formando progresivamente la lengua española: el latín convive durante un cierto período de tiempo ${ }^{8}$ con las lenguas propias de la Península

\footnotetext{
${ }^{8}$ El latín desplazó con facilidad a las antiguas lenguas del sur y del este de España: provincias Bética y Tarraconense. Tuvo más dificultades en progresar como lengua en el centro de la península y le resultó muy costoso establecerse en la cornisa cantábrica.
} 
Ibérica hasta llegar a hacerlas desaparecer. El grado de influencia de las antiguas lenguas peninsulares en el latín hablado en Hispania resulta una incógnita todavía no desvelada ${ }^{9}$ aunque generalmente se aceptan influencias en la pronunciación, tonalidad y ritmo del habla además de ciertas huellas en la morfología y en el léxico que caracterizaron el latín hispánico hasta la época en que nacieron los romances peninsulares.

Las influencias lingüísticas venidas de fuera de la península no terminan aquí aunque nunca llegarían a ser tan profundas como el influjo latino que, como sabemos, constituye la base de la lengua española. Durante la Edad Media dos civilizaciones sostenían en Hispania una prolongada rivalidad: la civilización cristiana y romano germánica compartía la península con el Islam. Los musulmanes formaron una sociedad, Al Andalus, que seguía el modelo cultural, religioso y lingüístico del pueblo árabe. Todos los estudiosos de la época constatan que nada en la historia de España puede entenderse sin considerar en su justa medida el impacto producido por la presencia de los musulmanes en la península. Sin desdeñar la influencia de las lenguas germánicas durante la época visigoda - a la que debemos voces como yelmo, dardo, guardar, guerra, etc. podemos observar cómo las lenguas peninsulares están cargadas de términos de origen árabe que comienzan a utilizar los mozárabes y no tardan en llegar a los reinos cristianos del norte de la península. Lapesa (1980: 133) señala que el elemento árabe fue, después del latino, el más importante del vocabulario español hasta bien entrado el siglo XVI, llegando a cuantificar en más de cuatro mil las voces de esta procedencia. Los arabismos son extremadamente frecuentes en campos como la guerra (atalaya, adalid, zaga, adarga, etc.), la agricultura (acequia, aljibe, alubias, zanahoria, etc.), el tráfico (arancel, aduana, tarifa, etc.) o la vivienda (zaguán, azotea, alcoba, alfeizar, albañil, etc.) También se mencionan otros campos como, por ejemplo, la vestimenta, las instituciones, las matemáticas, la medicina, los sentimientos, etc.

Cuando Al-Andalus empieza a perder su poder militar, los reinos cristianos del norte comienzan a extenderse hacia el sur, llevando consigo sus propios idiomas. En el siglo XIII Castilla se convierte en la monarquía más poderosa del centro peninsular y su idioma, en origen considerado bárbaro, continua asimilando diferentes formas lingüísticas

\footnotetext{
${ }^{9}$ Rafael Lapesa dedica tres apartados de su Historia de la lengua española (1980) al estudio de la influencia del sustrato preromano en la fonología, morfología y léxico español.
} 
procedentes de los distintos pueblos con los que se pone en contacto a lo largo de su expansión :

La historia del castellano medieval (...) es una constante serie de procesos de absorción y nivelación, de fusión de elementos de origen diverso, hasta llegar a unir dentro de sí lo que en su origen es un complejo de elementos dialectales diversos. (Cano 1995: 29)

Su carácter innovador es tan importante que diversos autores han llegado a considerarlo una Koiné y no una lengua de una determinada comunidad. Esta capacidad de integración de formas afines continúa a principios de la Edad Moderna, incrementada si cabe por la unión dinástica de las monarquías de Castilla y Aragón. El castellano incorpora entonces elementos de los dialectos aragonés y leonés.

La expansión del idioma pasa, al lado de la corona española, de la península ibérica a Europa y América llegando a convertirse durante los siglos XVI y XVII en una lengua de carácter internacional de la mano de monarcas tan poderosos como Carlos $\mathrm{V}$ o Felipe II. En este período el español adquiere prestigio en el mundo por ser el idioma de una potencia dominante en el terreno político, económico y militar. En el Nuevo Mundo la lengua española absorbe gran cantidad de elementos léxicos procedentes de las lenguas indígenas - el quechua, el guaraní, el nahua, el taino, etc. - principalmente utilizados para nombrar elementos de la naturaleza americana desconocidos en Europa: maíz, sabana, tabaco, tiburón, yuca, tomate, iguana, condor, caimán, etc. El Vocabulario de las voces provinciales de la América compilado en 1789 por Antonio de Alcedo reúne aproximadamente cuatrocientas voces indígenas que han pasado al español.

En el siglo XVIII el imperio español comienza a desvanecerse y Francia se convierte en la nueva gran potencia europea expandiendo su influencia por toda Europa. España no es una excepción a esta tendencia, como muestra el importante auge que experimentan los galicismos en distintos ámbitos de la vida española: la moda parisina trajo consigo chaqueta, pantalón, satén, corsé, etc., la cocina croqueta, merengue, etc., el mobiliario buró, sofá, secreter, etc. La influencia francesa se ve incrementada a raíz de los hechos acaecidos en Francia en 1789, dando lugar a la expansión de las ideas filosóficas y enciclopedistas y poniendo en marcha una red de relaciones comerciales que 
hacían de París el vértice de la vida social, cultural y económica de todo el mundo occidental. Así nos han llegado voces relativas a las actividades comerciales - financiero, bolsa, cotizar, aval, garantía, letra de cambio, etc. - actividad política - parlamento, debate, comité, etc. - y de la actividad administrativa - burocracia, personal, etc. Tan importante fue el influjo de la sociedad francesa en la española que se llegó a popularizar el término afrancesado para definir de manera despectiva a las numerosas personas que mostraban una especial querencia hacia todo lo proveniente de Francia.

Hacia finales del siglo XIX la influencia francesa comienza a decaer en los países de ámbito occidental siendo sustituida por una lengua no románica - el inglés - que, como veremos a continuación, se convertirá a lo largo del siglo XX en el idioma más extendido no sólo en occidente sino también en todo el mundo. En su libro English as a Global Language David Crystal destaca que a finales del siglo XX aproximadamente un tercio de la población mundial hace uso, en mayor o menor medida, de la lengua inglesa en algún ámbito de su vida cotidiana y reflexiona sobre su propagación por todos los países del planeta destacando principalmente la rapidez con la que esta expansión se ha llevado a cabo a partir de la década de los cincuenta:

No other language has spread around the globe so extensively, but what is impressive is not so much the grand total but the speed with which expansion has taken place since the 1950s. In 1950, the case for English as a world language would have been no more than plausible. Fifty years on, and the case is virtually unassailable. What happened in this fifty years - a mere eye-blink in the history of a language - to cause such a massive change of stature? (1997: 63)

Aunque, como hemos querido dejar claro a lo largo de este apartado, existen numerosos precedentes a lo largo de la historia que muestran el influjo de una lengua sobre otra, la actual influencia de la cultura y de la lengua anglosajona no tiene parangón en la historia de la lengua española, excepción hecha del influjo latino, ni tampoco en la historia de la humanidad. La magnitud del fenómeno ha dado lugar a encendidos debates acerca de la conveniencia de establecer medidas de protección de los idiomas que sufren la influencia anglicista: francés, italiano, español, etc. En el siguiente apartado trataremos brevemente la situación actual de la lengua española e introduciremos el mayor problema 
con el que, según numerosos autores, parece enfrentarse nuestro idioma: el influjo del inglés.

\subsection{2. - El siglo XX: la cuestión de los anglicismos}

Contrariamente a lo que se podría haber esperado, la crisis política y económica padecida por España a partir del siglo XVIII no ha tenido un efecto negativo en nuestro idioma si atendemos al número de hablantes que lo utilizan. Lapesa (1980: 462) afirma que la lengua española ha quintuplicado sus hablantes en los últimos 150 años cuantificándolos en 250 millones, de los cuales 220 la tienen como lengua materna. Otros estudiosos elevan el número de personas que se comunican mediante la lengua española a 350 e incluso 400 millones. Actualmente, es el idioma más hablado y el que experimenta un mayor crecimiento dentro de la familia románica, a gran distancia del portugués y del francés.

Su considerable número de hablantes y el desarrollo que están alcanzando diferentes países de habla hispana convierten al español en un idioma cada vez más relevante dentro del comercio mundial y, por consiguiente, comienza a tener peso internacional en ámbitos como los medios de comunicación de masas, la política, la economía, etc. Buena prueba de ello es el auge que ha experimentado la enseñanza del español más allá de nuestras fronteras en países como Estados Unidos, Reino Unido, Alemania, Suecia, Brasil, etc. Además de las escuelas y las universidades propias de cada país, el Instituto Cervantes - fundado en 1991 con el objetivo de fomentar el estudio y el conocimiento de la lengua y la cultura española e hispanoamericana en el mundo estimula su aprendizaje.

En líneas generales podemos afirmar que la lengua española goza de buena salud. Sin embargo, un somero repaso a los trabajos de diferentes lingüistas y filólogos interesados en el estudio de la situación de nuestra lengua muestra con claridad que existen dos problemas que preocupan cuando se examina el devenir del idioma español: el miedo a la fragmentación y la invasión de anglicismos. 
El primero de ellos es causa directa de su extensión geográfica y de su cada vez más creciente número de hablantes. Estudiosos de finales del XIX y principios del XX mostraban un cierto temor a que el español se diversificara, al igual que había ocurrido con el latín, dando lugar a diferentes idiomas de raíz hispana. Unos años más tarde, Lapesa (1963: 206) se preguntaba si los países hispanoamericanos jóvenes no tenderían a afirmar su carácter propio acentuando sus elementos diferenciales en el idioma hasta llegar a poner en peligro "la lengua común". Con el paso del tiempo hemos comprobado que esos temores se han revelado infundados debido a las características de la sociedad actual, muy distinta a la romana, y definida por factores que imposibilitan - o hacen muy difícil - la disgregación de una lengua. Entre otros, podemos mencionar los siguientes elementos unificadores: el incremento espectacular de la instrucción escolar, el papel uniformador de los medios de comunicación de masas, de las producciones televisivas, cinematográficas, musicales o teatrales, el aumento de los intercambios interfronterizos por la facilidad para viajar y asentarse en países distintos, la apertura de mercados internacionales debido a la actual economía globalizada, etc.

El segundo problema que inquieta a los filólogos se refiere al tema que nos compete directamente en este trabajo y que, al contrario de lo que ocurría con el anteriormente examinado, adquiere día a día una mayor relevancia. Nos referimos a la influencia que la lengua inglesa y la cultura angloamericana ejercen sobre el idioma español. Cano Aguilar considera que la lengua española está en una posición subordinada respecto a la lengua inglesa debido, sobre todo, a la preponderancia del inglés en el terreno científico y tecnológico:

El principal problema [del español] parece ser que en el mundo de hoy el prestigio de una lengua va asociado no sólo al hecho de ser la lengua de una potencia dominante en lo político, lo económico y lo militar (como ocurrió con el español en el XVI y XVII, con el francés en el XVII y XVIII y con el inglés en el XIX y XX), sino, sobre todo, al de ser la lengua en que se expresan la ciencia y los avances tecnológicos. Ninguna de las dos ventajas tiene hoy por hoy el español, ni parece que vaya a tenerlas en un próximo futuro. De ahí su posición subordinada, dependiente, ante el inglés, que sí reúne ambos privilegios. (1995: 34) 
La asunción de este hecho y la posición adoptada por los estudiosos que se han preocupado de estudiar el tema oscila entre el rechazo más radical a cualquier tipo de influencia foránea y la tolerancia hacia este fenómeno por considerarlo como una realidad natural existente, en mayor o menor medida, en todas las sociedades avanzadas de nuestra época.

Madariaga (1966) y Alfaro (1970) pueden considerarse representantes de la actitud purista. Sus trabajos pretenden concienciarnos de la necesidad de prescindir de los anglicismos denominados innecesarios ${ }^{10}$ por considerar que constituyen una influencia deformante que contamina la pureza del idioma español. Pratt (1980), Quilis (1984) y Lorenzo (1955), (1996) defienden la postura contraria, certificando que la influencia angloamericana es un hecho en nuestro idioma actual y que no tiene por qué significar una influencia negativa ya que principalmente contribuye a ampliar nuestro léxico con nuevos matices. Sin embargo, antes de abordar este tema en profundidad debemos preguntarnos sobre los factores que han propiciado la actual situación de la lengua inglesa en el mundo. Para ello, creemos conveniente dedicar los siguientes apartados a examinar el papel actual de la lengua inglesa como lingua franca y el influjo que irradia sobre la lengua española.

\section{2. - LA LENGUA INGLESA EN EL SIGLO XX}

\subsection{1. - La expansión de la lengua inglesa}

Como ya hemos visto anteriormente, el siglo XVIII se había caracterizado por una preponderancia económica, política y cultural del francés, idioma que disfrutaba de una posición muy superior a la de cualquier otra lengua, incluyendo la lengua inglesa. Sin embargo, en este mismo siglo comenzamos a encontrar ciertas voces ${ }^{11}$ que predicen un

\footnotetext{
${ }^{10}$ Ambos autores sostienen que la mayor parte de los anglicismos existentes en la lengua española no son necesarios. En el apartado 1.5. examinaremos los criterios establecidos por diferentes autores a la hora de considerar un anglicismo como necesario o innecesario.

${ }^{11}$ Crystal (1997: 65) destaca la opinión del conde de Chesterfield sobre la expansión del inglés a mediados del siglo XVIII: "I have... a sensible pleasure in reflecting upon the rapid progress which our language has lately made, and still continues to make, all over Europe" o el punto de vista de David Hume en 1767: "Let the French, therefore, triumph in the present diffusion of their
} 
cambio en esta situación. El 23 de Septiembre de 1780 John Adams, el segundo presidente de los Estados Unidos de América, formula la siguiente previsión al presentar una propuesta al congreso de su país con el objetivo de crear una academia americana:

English is destined to be in the next and succeeding centuries more generally the language of the world than Latin was in the last or French is in the present age. The reason of this is obvious, because the increasing population in America, and their universal connection and correspondence with all nations will, aided by the influence of England in the world, whether great or small, force their language into general use, in spite of all the obstacles that may be thrown in their way, if any such there should be. (en Crystal 1997: 66)

La situación actual de la lengua inglesa en el mundo nos permite comprobar que la predicción de John Adams distaba de ser errónea. Strevens (1992: 29) afirma que desde sus orígenes a mediados del siglo XIV hasta finales del siglo XVI el inglés no había conseguido sobrepasar los siete millones de hablantes y ni siquiera se había establecido como el idioma de todos los habitantes de las Islas Británicas ${ }^{12}$. Sin embargo, bien entrado el siglo XVII se produce un giro determinante en esta situación y se comienzan a sentar las bases de la expansión mundial de la lengua inglesa:

The combination of industrial development and the British Empire helped position English as the language of global trade, at a time when trade was taking over from diplomacy as the basis for international affairs. French was the catholic language of ideas and diplomacy. Its promoters made much of its beauty, literature and civilised cultural values. English was the protestant, working language of commerce. Its supporters promoted its virtues with frequent reference to numbers relating to its size and global reach. (Crystal 1999: 31)

tongue. Our solid and increasing establishments in America ... promise a superior stability and duration to the English language."

${ }^{12}$ Graddol también cifra en siete millones los hablantes de inglés en el siglo XVI: "Before the European colonization of North America in the $17^{\text {th }}$ century, the number of first language English speakers could not have exceeded about seven million, almost all in the British Isles. During the $19^{\text {th }}$ century, numbers of English speakers in North America overtook those in the British Isles, but numbers of native English speakers worlwide are unlikely to have passed the 100 million mark until the end of the $19^{\text {th }}$ century" (1999: 32 ). 
El propio Crystal (1997: 110) considera que su expansión ha tenido tanto éxito por haberse encontrado en el lugar correcto en el momento adecuado ${ }^{13}$. Durante el siglo XVII y XVIII el inglés era el idioma de la primera potencia colonial del mundo: el Reino Unido. En el siglo XVIII y XIX era la lengua hablada en el país donde surge la revolución industrial y a finales del XIX y durante el siglo XX el inglés es el idioma de la mayor potencia económica mundial: los Estados Unidos de América. Este autor atribuye la supremacía actual de la lengua inglesa a dos factores que considera determinantes para su desarrollo: la expansión del Imperio Británico que llega a su apogeo a finales del siglo XIX y el surgimiento de los Estados Unidos como primera potencia política y económica mundial en el siglo XX.

Después de haber mencionado sucintamente los factores históricos que han propiciado la expansión de la lengua inglesa, dedicaremos los siguientes apartados a reflexionar acerca de dos ámbitos que pueden ayudarnos a comprender tanto su evolución en la esfera internacional como su actual papel de lingua franca en la mayoría de los países del mundo. Nos estamos refiriendo a los ámbitos económico y político.

\subsection{2. - El inglés y la economía internacional}

Especialmente relevante resulta el hecho de que el Reino Unido haya sido la cuna de la revolución industrial y consecuentemente de las innovaciones tecnológicas que este período trae consigo: el inglés James Watts perfecciona la máquina de vapor, en las fábricas se aprovecha el carbón como recurso energético, se obtienen nuevos materiales para su uso industrial, se desarrollan nuevos medios de transporte, etc. Estos avances tienen un efecto inmediato en la lengua inglesa ya que exigen la rápida incorporación de

\footnotetext{
${ }^{13}$ Esta apreciación de Crystal ha sido considerada por Phillipson como "naive" y triunfalista en la crítica que este último autor hace de su libro English as a Global Language en la revista "The European English Messenger" (1999). Crystal se defiende de la anterior acusación argumentando que intentaba expresar un cierto tono irónico: "Phillipson, for example, has totally missed the conventional irony implicit in my use of the phrase "[English being] in the right place at the right time". (...) When someone says this, they are typically reflecting on the unexpected and often undeserved good fortune of the recipient. If I say, when John turns up at the bar just as I'm offering to buy a round of drinks, "John's always in the right place at the right time", I am not praising him, nor being triunphalist about him. The usage is ironic. Rather than trivialising the issue, the phrase adds a depth to it, which Phillipson has completely missed" (1999: 64).
} 
una terminología específica de carácter científico-técnico que posibilite referirse a los nuevos elementos de la emergente sociedad industrial.

A todo ello se añade una segunda consecuencia socio-lingüística del anterior fenómeno que comienza a marcar la decisiva influencia del inglés sobre otros idiomas y que consituye el germen de la, hasta hoy, inseparable unión entre lengua inglesa y tecnología. Crystal señala que en este período delegaciones procedentes de diferentes países visitaban Inglaterra para conocer los adelantos tecnológicos que allí se estaban llevando a cabo. El uso de la lengua inglesa resultaba imprescindible para entender el funcionamiento de los nuevos métodos de producción industrial y los hablantes de otros idiomas interesados en conocer los nuevos adelantos se veían obligados a aprenderla:

(...) the fact that these innovations were pouring out of an English-speaking country meant that those from abroad who wished to learn about them would need to learn English - and learn it well - if they wished to benefit. Especially after the French Wars (1792-1815), missions of inquiry arrived in Britain from several continental countries, foreign workers were seconded to British factories, and many Britons came to earn a good living abroad, teaching the new methods of industrial production. (1997: 72)

El Reino Unido era la primera potencia industrial del mundo durante el siglo XVIII y cuando pierde su posición privilegiada lo hace a favor de los Estados Unidos, otro país de habla inglesa, que se convierte en la mayor potencia industrial del planeta desde finales del siglo XIX hasta nuestros días. Así nos encontramos con que, desde el principio de la revolución industrial, la lengua inglesa ha estado directamente imbricada en los más relevantes procesos industriales y económicos ${ }^{14}$ mundiales. Gracias a ello, el inglés se ha convertido en un idioma imprescindible en todos los países que aspiran a conseguir una capacidad tecnológica, industrial o económica puntera.

Una particularidad que distingue la expansión de la lengua inglesa de otras acontecidas a lo largo de la historia se refiere al papel desempeñado por numerosos países no anglófonos que, a la vez que defienden su propio idioma, fomentan la lengua inglesa por su marcado carácter instrumental en áreas específicas como, por ejemplo, la tecnología, el comercio, las investigaciones científicas, la educación, etc. Así, en países

\footnotetext{
${ }^{14}$ Algo muy parecido ocurrirá en el caso de la publicidad como veremos en el apartado 1.6.2.
} 
tan diversos como Japón, Alemania, Italia, Argentina, España, etc. el inglés se ha reconocido como un idioma necesario en determinados ámbitos, fomentándose activamente su uso y conocimiento:

Whether we monitor the veritable army of English-speaking econo-technical specialists, advisors, and representatives, or whether we examine the diffusion of English publications, films, radio and television programs and educational opportunities, it's becoming increasingly clear that non-English mother tongue countries are significantly active in each of these connections. (Fishman 1992: 20)

El éxito de la lengua inglesa en el mundo actual se debe en gran parte a su imagen de idioma-llave que posibilita el progreso, la riqueza y la prosperidad de una nación y que frecuentemente se percibe como libre de connotaciones étnicas o ideológicas. Strevens (1992: 31) distingue entre países donde, por razones históricas, la lengua inglesa tiene un papel determinado en la sociedad - ethnocentered use of English - y países que no han sufrido un influjo histórico relevante de naciones de habla inglesa pero, sin embargo, utilizan este idioma en ámbitos laborales, de investigación, ocio, etc: non ethnocentered use of English. Es en estos últimos donde el inglés se considera como una ventana que posibilita acceder al mundo de la ciencia, la tecnología y el progreso, lo que ha constituido un reclamo que muy pocos países han estado dispuestos a ignorar: "The discourse accompanying and legitimating the export of English to the rest of the world has been so persuasive that English has been equated with progress and prosperity" (Phillipson 1992: 11).

Sin embargo, existen ciertos autores (Görlach 1988, Phillipson 1992) que discrepan de la equivalencia entre la lengua inglesa y el progreso ajeno a cualquier ideología ${ }^{15}$. Contrariamente, consideran la expansión internacional del inglés como una

\footnotetext{
${ }^{15}$ En el artículo "On trying to be Crystal-clear: a response to Phillipson" publicado por David Crystal en la revista "The European English Messenger" (1999) encontramos una buena prueba de las diferentes posturas existentes a la hora de examinar las consecuencias de la expansión internacional de la lengua inglesa. Phillipson acusa a Crystal de llevar a cabo un estudio del tema desde una perspectiva excesivamente triunfalista y sin considerar la vertiente sociológica de la situación. Por su parte, Crystal se defiende de las anteriores acusaciones y argumenta que el trabajo de Phillipson en este campo - principalmente su obra Linguistic Imperialism (1992) - está marcado por sus postulados ideológicos que se limitan a atribuir la expansión de la lengua inglesa a su subordinación ante oscuros intereses económicos transnacionales.
} 
de las piedras angulares en las que se sostiene el actual sistema capitalista, a menudo regido por poderosos intereses supranacionales que no siempre resultan beneficiosos para los países sometidos a su influjo. Fishman defiende que las ideas de progreso y prosperidad que se asocian a la lengua inglesa sí que van acompañadas de un claro componente ideológico. Este hecho es especialmente evidente en los países englobados dentro de lo que hemos dado en llamar el Tercer Mundo:

The relative unrelatedness of English to ideological issues in much of the Third World today must not be viewed as a phenomenon that requires no further qualification. Westernization, modernization, the spread of international youth culture, popular technology and consumerism are all ideological as well as behavioral and econo-technical consequences. (Fishman 1977: 118)

\subsection{3. - El inglés y la política internacional}

La supremacía de la lengua inglesa en el terreno político no comienza hasta principios del siglo XX, más concretamente después de la Primera Guerra Mundial. Phillipson (1992) y Crystal (1997) destacan que el Tratado de Versalles, redactado en inglés y francés - idioma de la diplomacia por excelencia en esa época - supone el final del status del francés como la lengua de la política internacional:

The fact that the two languages were accorded equal validity at the peace conferences and that the Treaty of Versailles was drawn up in both French and English led to these two languages becoming the official languages of the League of Nations and of the Permanent Court of International Justice (Lieberson 1982: 42). The French were adamantly opposed to the upgrading of English, but the presence of the Americans at the peace conference was decisive. The French were well aware that the recognition of equal status for English marked the end of the era of French linguistic preeminence. (Phillipson 1992: 33)

Sería innumerable mencionar todas las instituciones en las que el inglés tiene un papel oficial hoy en día. Como muestra comentaremos las conclusiones más relevantes del análisis que David Crystal (1997: 79) lleva a cabo del Union of International Associations yearbook, libro que recoge 12.500 organizaciones internacionales existentes 
en el mundo en el período 1995-1996. Su estudio establece los siguientes datos: el 85 por ciento de las organizaciones internacionales tienen la lengua inglesa como una de sus lenguas oficiales. En segundo lugar aparece, a gran distancia, el Francés con un 49 por ciento. Sólo el español, el árabe y el alemán sobrepasan el diez por ciento.

No obstante existe un dato que todavía consideramos más relevante: numerosas organizaciones internacionales utilizan exclusivamente la lengua inglesa. Uno de los primeros ejemplos ha sido el acuerdo internacional para utilizar el inglés en todos los organismos encargados de regular el tráfico aéreo mundial. Crystal (1997) destaca que el 33 por ciento de las organizaciones presentes en su estudio utilizan exclusivamente la lengua inglesa y cita, entre otras, las siguientes: Organization of Petroleum Exporting Countries, European Free Trade Association, European Academy of Anaesthesiology, African Hockey Federation, European Association of Cancer Research.

Sólo el trece por ciento de las organizaciones internacionales estudiadas no hacen uso oficial del inglés. Se trata mayormente de asociaciones de países francófonos o hispanos que, aunque formadas por diferentes naciones, comparten un idioma común. Sin embargo, cuando estas asociaciones elaboran un informe de sus conclusiones dirigido a la prensa internacional utilizan, además de la lengua oficial de la organización, la lengua inglesa.

\subsection{4. - Situación actual del inglés en el mundo}

La lengua inglesa, aunque muy difundida, no tiene una situación homogénea en los distintos países en los que se utiliza. El lingüista americano Braj Kachru explica la expansión del inglés en el mundo y su uso actual mediante tres círculos concéntricos que pasamos a definir a continuación ${ }^{16}$ :

\footnotetext{
${ }^{16}$ Phillipson propone una clasificación alternativa a la de Kachru en la que distingue entre core English-speaking countries - que estaría formado por los países del círculo interior definido por Kachru - y periphery-English countries, que englobaría los países pertenecientes al círculo exterior y al círculo en expansión de Kachru. Dentro de este segundo grupo establece la siguiente distinción: "The periphery-English countries are of two types: countries which require English as an international link language (Scandinavia, Japan, etc.) and countries on which English was imposed in colonial times, and where the language has been successfully transplanted and still serves a range of intranational purposes (India, Nigeria, etc.)" (1992: 17).
} 
1 - El círculo interior (inner circle) - compuesto por los países donde la lengua inglesa es el idioma principal: Estados Unidos, Reino Unido, Irlanda, Canadá, Australia, Nueva Zelanda, etc.

2 - El círculo exterior (outer or extended circle) - formado por países donde, habitualmente mediante una colonización temprana, la lengua inglesa ha llegado a desempeñar un papel relevante en las instituciones más importantes del país aún tratándose en principio de una lengua foránea. Se trata de naciones plurilingües en las que el inglés funciona como segunda lengua ${ }^{17}$ : India, Singapur, Malawi, Nigeria, etc.

3 - El círculo en expansión (expanding circle) - compuesto por territorios que aunque nunca han sido colonizados por países del círculo interior reconocen la importancia del inglés como lengua internacional. En ellos el inglés se enseña como idioma extranjero y aquí situaríamos a España, Francia, Dinamarca, Holanda, Portugal, Grecia, Polonia, China, Argentina, Chile, etc.

No es sencillo cuantificar el número de personas que utilizan la lengua inglesa en el mundo ${ }^{18}$. Además es necesario distinguir entre hablantes nativos y hablantes no nativos. Las cifras que aparecen con mayor profusión son las siguientes: 350 millones de personas tienen el inglés como L1 y 700 o 750 millones lo utilizan como L2. Crystal (1997) considera que existen entre 320 y 380 millones de hablantes nativos - mayormente pertenecientes al círculo interior - y entre 1000 y 2000 millones de hablantes no nativos que, aunque de manera limitada, utilizan la lengua inglesa en ciertos momentos de su vida $^{19}$. Strevens (1992: 28) se inclina por un término medio y cuantifica los hablantes ocasionales de inglés como L2 en 1500 millones.

\footnotetext{
${ }^{17}$ Strevens distingue entre segunda lengua y lengua extranjera dependiendo de la función que desempeñe en la sociedad: "English is a foreign language within a community when it has no special standing but is simply "just another language"; whereas English is a second language when it has special standing, such as being acceptable in the courts of law, being the medium of instruction in mayor sectors of the educational system, being used in regional or national administration, being commonly used on radio or television, and where there are major newspapers published in English" (1992: 36).

${ }^{18}$ Para un estudio en profundidad del tema, véase el artículo de David Graddol "The Decline of the Native Speaker" editado por Graddol y Meinhof y publicado en English in a Changing World (1999).

${ }^{19}$ Los datos anteriores (700-750 millones) se habían obtenido atendiendo al número de lectores de periódicos en lengua inglesa en países no anglófonos. Crystal (1997) toma sus datos del número estimado de hablantes que, en algún ámbito de su vida personal o profesional, hacen uso de la lengua inglesa.
} 
De estos datos podemos deducir dos conclusiones principales. La primera, anteriormente mencionada, manifiesta el hecho de que casi un tercio de la población mundial utiliza, en mayor o menor medida, la lengua inglesa. La segunda, más importante si cabe, se refiere a la desigualdad numérica existente entre hablantes nativos y hablantes no nativos ya que los hablantes de inglés como L1 son una minoría comparados con los hablantes no nativos:

For the figures tell us that while English is used by more people than any other language on Earth, its mother-tongue speakers make up only a quarter or a fifth of the total. Further, these immense numbers are only possible because there exist in several parts of the world - in South Asia, in parts of Africa, in the Far East, even in Europe communities of English users in which the native speakers are heavily outnumbered by non-native speakers. (Strevens 1992: 28)

Esta situación no parece tener visos de cambio. Centrándose en los datos relativos al círculo interior y exterior, David Crystal destaca que aunque en 1995 todavía son más numerosos los hablantes que tienen el inglés como L1, el incremento de población en los países del círculo exterior traerá consigo que los hablantes no nativos sobrepasen a los nativos:

But the countries of the outer circle have, combined, a much greater growth rate than those of the inner circle: in 1995-6, an average of 2.3 per cent compared with 0.8 per cent. So, if current population and learning trends continue, this balance will soon change. Within ten years, there will certainly be more L2 speakers than L1 speakers. Within fifty years, there could be up to 50 per cent more. (1997: 130)

La conclusión que se puede extraer de este análisis es clara: el inglés se ha transformado y se seguirá transformando cada vez más en una lengua global y su éxito como tal estará determinado, en gran medida, por las actitudes de los países no anglófonos: "English is less and less regarded as a European language, and its development is less and less determined by the usage of its native speakers" (Ferguson 1992: XVI). 


\section{3. - LA INFLUENCIA ANGLOAMERICANA EN EL ESPAÑOL MODERNO}

El papel desempeñado por la lengua inglesa como idioma global - o lingua franca - acarrea dos consecuencias lingüísticas en las sociedades no anglófonas. La primera, conscientemente buscada, se refiere a la existencia de ciertos ámbitos - económicos, políticos, de ocio, etc. - donde se fomenta, o simplemente se tolera, su uso bien de forma activa o bien de manera pasiva ${ }^{20}$. La segunda consecuencia, directamente relacionada con la anterior pero no conscientemente buscada, se refiere a la influencia que la lengua extranjera ejerce sobre el idioma propio del país, lo que en nuestro caso se conoce como el influjo anglicista que, como veremos en el apartado 1.5.2., dispone de muy distintas vías de entrada. Veamos el siguiente ejemplo.

Emilio Lorenzo, testigo privilegiado de la emergencia del inglés en el sistema educativo español, considera que la metodología actualmente utilizada en la enseñanza del idioma extranjero - procurando evitar a toda costa la negativa interferencia de la lengua materna en el proceso de adquisición - facilita la entrada de numerosos elementos léxicos, clichés, giros o metáforas que no son propios de la lengua española:

Y así penetran y se van imponiendo frases y construcciones antes desconocidas en nuestro idioma: el acicate y la disuasión se convierten en el palo y la zanahoria, lo que se explica en inglés, donde carrot significa, además de "zanahoria", algo ofrecido como “incentivo o cebo". También es dicotomía inglesa el enfrentar belicistas y pacifistas en términos ornitológicos (halcones y palomas = inglés hawks and doves)... (1995: 172)

Este fenómeno, que no es exclusivo del ámbito de la enseñanza, prueba que la presencia de la lengua inglesa en España, en primer lugar, posibilita su uso a muchos

\footnotetext{
${ }^{20}$ La integración de España en la Unión Europea también ha contribuído al fomento de la lengua inglesa, aunque si nos comparamos con otros países de nuestro entorno podemos concluir que su uso todavía resulta escaso: "Eurobarometer 41, based on data collected at the end of 1994 and analysed by Labrie and Quell (1997), found large country variations in English usage, ranging from Spain (with 13\% of adults able to hold a conversation in English) to the northern European countries such as Sweden (75\%) and Netherlands (71\%)" (Graddol 1999: 35).
} 
hablantes no nativos pero también influye en la utilización que estos mismos hablantes hacen de su propia lengua materna ${ }^{21}$. En este apartado vamos a llevar a cabo un recorrido histórico a través de los casi dos siglos de influencia angloamericana en la lengua española distinguiendo cuatro períodos principales $^{22}$ que estudiaremos a continuación. Utilizamos el término angloamericano debido a que tanto Inglaterra como los Estados Unidos han desempeñado, en distintos momentos, un papel importante en el suministro de préstamos: aunque al comienzo del fenómeno la inmensa mayoría de las palabras procedían del inglés británico, a partir de mediados del siglo XX, cuando la influencia se dispara, casi todos los préstamos venían del inglés americano. Gómez Capúz también muestra su preferencia por el término angloamericano:

Hablamos de influencia angloamericana y no de inglesa porque pensamos que la eclosión y la expansión del anglicismo en español - y no sólo el anglicismo léxico - se da a partir de 1945, a causa de la hegemonía política, cultural y lingüística de los Estados Unidos de América y su creciente intervencionismo en Europa. (1993: 1290)

\subsection{1. - Primer período: 1820 - 1910}

La literatura inglesa puede considerarse como el primer elemento que facilita la adquisición de anglicismos a lo largo del siglo diecinueve:

La lengua inglesa, que había permanecido ignorada en el continente durante los siglos XVI y XVII, empezó después a ejercer influencia, primero con su literatura y pensadores, más tarde por el prestigio social. Los románticos querían deslumbrar con

\footnotetext{
${ }^{21}$ Lorenzo también pone de manifiesto que muchos profesores de lengua inglesa descuidan su idioma materno favorenciendo así la entrada indiscriminada de préstamos en el español: "Lo que echamos en falta (...) es el descuido notable del español, que a la hora de medir el influjo del inglés resulta a veces lamentable y contribuye, en consecuencia, al uso de los calcos y préstamos que son materia de nuestro estudio" (1996: 18).

${ }^{22}$ En "Tendencias en el estudio de las diversas etapas de la influencia angloamericana en español moderno" (1993) Juan Gómez Capúz distingue tres períodos coincidentes con las tres primeras etapas que presentamos en nuestro esquema. A ellas añadimos una cuarta etapa que no está presente en el estudio diacrónico de la influencia angloamericana en español llevado a cabo por Gómez Capúz, pero sí se parece implicar en sus estudios posteriores como, por ejemplo, "La madurez del anglicismo en el español actual: el ejemplo de la lengua juvenil” (1997).
} 
elegancias de dandy, paseaban en tilbury, conspiraban en el club, y como Larra, gustaban del Rosbif y el biftec. (Lapesa 1980: 457)

Jovellanos, Cadalso y Moratín traducen obras literarias del inglés al español y escritores como Espronceda, Vicente Salvá, Blanco White o el Duque de Rivas se ven obligados a emigrar a Inglaterra debido al gobierno absolutista de Fernando VII: "Es sintomático que sea después de 1834 - fecha del regreso de los emigrados tras la muerte de Fernando VII - cuando comienzan a verse voces inglesas en diversas publicaciones españolas" (Gómez 1993: 1290).

Las obras escritas constituían la principal vía de entrada de las nuevas voces inglesas, aunque, como bien señala Fernández García (1971: 9), no se puede olvidar el papel jugado por la estancia de ejércitos ingleses en la península debido a la Guerra de la Independencia que pudo propiciar la entrada de algún préstamo por vía oral.

Como ya hemos indicado en el apartado 1.1.1. el siglo XVIII se había caracterizado por una polarización social entre las gentes que gustaban y participaban de las nuevas costumbres venidas de Francia y los que despreciaban toda influencia gala. En lo relativo al lenguaje, el galicismo fue ferozmente combatido desde el principio ${ }^{23}$ y los anglicismos de la época se achacaban a la influencia francesa:

Por lo general, la crítica englobaba [las voces inglesas] entre los galicismos o como vocablos introducidos por el francés; sin duda, muchos vinieron por ese camino, pero no puede descartarse, de ningún modo, la importación directa desde el mismo inglés. (Fernández 1971: 10)

Lapesa (1963) (1980), Pratt (1980) y Lorenzo (1996) reconocen que el francés ha funcionado como lengua de enlace entre el inglés y el español en la adopción de préstamos. Por esta vía han entrado palabras como autostop , footing, camping, rally,

23 Fernández García menciona varias obras y diferentes autores que se oponían al uso de galicismos: "El Diario de los Literatos acusa ya esta influencia y descubre "galicismos" que se les escapan a los traductores de obras francesas. El Padre Isla e Iriarte se burlan de los que tratan de imitar las nuevas costumbres y de los galiparlantes. Vargas Ponce, en las postrimerías del XVIII, ataca con dureza la sustitución de términos castizos por otros advenedizos" (1971: 9). 
smoking, etc. ${ }^{24}$ Sin embargo, no es hasta el último tercio del siglo XIX cuando comienzan a aparecer síntomas de rechazo hacia el anglicismo por parte de ciertos autores que se consideraban en la obligación de defender la pureza de la lengua española, lo que constituye una prueba irrefutable de su abundancia:

Ruíz de León (1879) es el primero que tilda de "adefesios" a anglicismos como Cámaras (del Parlamento), Skating-ring, Jockey-Club y handicap. Igualmente, los vocabularios y obras prescriptivas de Ana Oller, Oliver y Orellana califican de "pedantería de primo cartello", "vergonzante, de mala catadura" anglicismos (...) como fashionable, dandy, sportsman, meeting e interview. (Gómez 1993: 1291)

\subsection{2. - Segundo período: $1910-1939$}

Esta segunda etapa puede caracterizarse por el declive del influjo francés y la confirmación del influjo angloamericano. Fernández García considera que es en este período cuando se produce la segunda gran oleada de anglicismos, hecho que atribuye a la influencia de los modelos anglosajones que emanaban del todavía existente Imperio Británico y de la nueva potencia americana, ambos vencedores en la Primera Guerra Mundial. Gómez Capúz considera que aunque el número es amplio su temática se concentra en ciertos ámbitos muy restringidos:

Los anglicismos de este período todavía son limitados en su temática y se concentran en tres áreas semánticas especialmente inestables respecto a su permanencia en el idioma: los deportes (golf e hípica sólo eran conocidos por la alta burguesía), vida social (muchos hoy caducos) y avances técnicos (incluyendo nombres de marcas comerciales hoy desconocidas).

(Gómez 1993: 1292)

\footnotetext{
${ }^{24}$ Lorenzo también destaca que casi todos los anglicismos léxicos anteriores al siglo XX han venido a través del Francés como, por ejemplo, Londres, equipar, contradanza, biftec, francmasón, club, boxeo, etc: "Alguno de éstos es calco libre o etimología popular del francés, donde se esconden, borrosos y engañosos, los formantes del compuesto inglés (country dance, beef steak, free mason). Otros calcos, menos deformados, son librepensador (free thinker) y tranvía (tramway). Ello sin contar los numerosos préstamos del inglés que enfurecen, sin razón, a los puristas franceses, ya que son, de hecho, galicismos tomados por el inglés de la que fue lengua de los dominadores de su país tras la conquista de la isla por las huestes de Guillermo de Normandía" (1995: 167).
} 
Boxeo, boicot, charleston, forward, pickup (tocadiscos), speaker, smart, etc. son anglicismos propios de esta época que con el paso del tiempo han sufrido una suerte dispar: alguno de ellos se ha consolidado en su uso y otros han sido sustituidos por un equivalente español. Además debemos señalar que la mayor parte de los anglicismos característicos de este período eran exclusivamente utilizados por un sector minoritario de la sociedad - la burguesía - siendo más bien escasos los que gozaban de una difusión general:

Hasta mediados del siglo XX los anglicismos de orden léxico con difusión general se podían contar por docenas, siendo el híbrido Inglaterra probablemente el más antiguo. Términos relativos a la navegación serían también huellas de una influencia natural entre naciones que comercian por vía marítima o ventilan sus disputas en el mar: bote, borda, babor y los puntos cardinales podrían ser testimonio de ello. (Lorenzo 1995: 167)

\subsection{3. - Tercer período: $1939-1970$}

Dentro de este tercer período podemos distinguir dos etapas relativas a la evolución del anglicismo en la lengua española: la primera década del régimen franquista y los años 50 y 60. Los primeros años del régimen franquista suponen un freno a la influencia del inglés que puede comprenderse al examinar la situación socio-política nacional caracterizada por el establecimiento de valores conservadores en todos los ámbitos de la vida y que se reflejaban en el idioma mediante una inequívoca tendencia al purismo:

Oficialmente, ha habido una sola época de nacionalismo lingüístico: la de la "autarquía" de 1939 a 1950, aproximadamente. Se nacionalizaron entonces muchas palabras extranjeras que circulaban corrientemente, por ejemplo en el deporte y, aunque en algunos casos fue con éxito (verbigracia match - encuentro, back - defensa, speakerlocutor), en general no llegó a cuajar en resultados visibles. (Seco 1977: 200) 
Pratt (1980) señala que la americanización de la sociedad española es más tardía que la de otros países europeos por no haber tenido una presencia americana inmediatamente posterior a la Segunda Guerra Mundial. Hasta los años cincuenta, cuando el régimen franquista comienza a cambiar su postura hacia los Estados Unidos, no se reanuda la entrada de anglicismos ${ }^{25}$. La aparición del turismo de masas y su despegue en las décadas siguientes también constituye un factor que ayudará a consolidar su penetración.

Ralph Penny considera que los años cincuenta constituyen un punto de inflexión tanto en lo relativo al origen de los préstamos adquiridos por el idioma español como a las vías de entrada que utilizaban:

Until the middle of the twentieth century, almost all English words borrowed by Spanish were of British English origin, and were usually transmitted through writing, often via French. From the 1950's onwards, the main source of such borrowings has been American English, and anglicisms have been transmitted partly through written media (especially newspapers, translation of scientific works, etc.), but increasingly through the oral media (dubbing of American films, TV programmes, etc.) (1991: 230)

En el prólogo a su Diccionario de Anglicismos, Alfaro compara el anterior influjo galicista con la actual influencia anglicista y achaca a estas nuevas vías de entrada la mayor presencia y difusión de elementos provenientes del inglés en la lengua española:

En el español hablado y escrito de nuestros tiempos la influencia del idioma inglés tiene preponderancia mucho mayor que la del francés. La intensidad de esa influencia tiene su razón de ser. El galicismo tenía el libro como vehículo casi único. El anglicismo tiene varios conductos de penetración por donde se cuela como corriente ora impetuosa, ora sutil, siempre efectiva. (1970: 9)

\footnotetext{
${ }^{25}$ Troike destaca que a partir de los años cincuenta los Estados Unidos e Inglaterra comienzan una importante campaña de promoción de la lengua inglesa a nivel internacional: "The spread of English was also greatly abetted by the expenditure of large amounts of government and private foundation funds in the period 1950-1970, perhaps the most ever spent in history in support of the propagation of a language" (en Phillipson 1992: 7).
} 
Las nuevas vías de entrada de anglicismos - mayormente medios de comunicación de masas procedentes de los Estados Unidos - y el origen de los préstamos indica que se ha producido un cambio importante en la orientación de la sociedad española: el país que a partir de ahora se constituye como referencia externa ineludible ya no es el Reino Unido ni cualquier otro país europeo sino que pasa a ser los Estados Unidos de América. Este cambio, que sobrepasa el campo del lenguaje propiamente dicho, ha sido exhaustivamente examinado por Chris Pratt en su libro El anglicismo en el español peninsular contemporáneo $^{26}$. Pratt estudia el influjo que el American way of life comienza a ejercer sobre todos los aspectos de la vida, las instituciones y las costumbres españolas a partir de los años cincuenta destacando los cambios que se han producido en España a raíz del 31 de Octubre de 1950, fecha en la que se revocan muchas medidas aislacionistas por parte del gobierno español y que traen consigo el restablecimiento de relaciones diplomáticas con numerosos países europeos, el acuerdo económico-militar hispanoamericano de 1953 que supuso, entre otras cosas, la llegada de los soldados norteamericanos a Torrejón de Ardoz, y, lo que es más importante, el establecimiento de patrones de conducta social que provenían de los Estados Unidos en campos como la comida, el ocio, los hábitos de consumo, la moda, etc. Esta nueva situación también propiciará el establecimiento en España de compañías americanas, síntoma inequívoco del declive del período aislacionista sufrido por nuestro país y prueba de la entrada de España en el sistema económico occidental:

La presencia de compañías americanas (quizás disfrazadas a veces de españolas o multinacionales por motivos de derecho mercantil o conveniencia económica) es muy destacada en España. En gran medida la empresa española se ve obligada a salir de su situación feudal por la necesidad de competir con el comercio extranjero. Casi no hay sector donde no haya una empresa norteamericana que aporte dinero, tecnología o knowhow. (Pratt 1980: 74)

Esta revolución social tiene un reflejo casi inmediato en el idioma debido a la necesidad de lexicalizar los nuevos elementos que comienzan a formar parte de la

\footnotetext{
${ }^{26}$ El libro España Americanizada publicado en 1995 por Alberto Moncada también examina el influjo americano en la sociedad española a partir de la década de los años cincuenta en campos
} 
sociedad española. Algunos anglicismos surgidos a raíz del mundo del consumo y del modo de vivir característico de estos años son: hippy, boicot, lunch, living, hobby, nightclub, jeep, grill, cocktail, meeting, ring, film, cowboy, etc.

\subsection{4. - Cuarto período: 1975 - 2000}

El rápido desarrollo que ha experimentado la sociedad española en los últimos veinticinco años ha traído consigo una vertiginosa evolución del anglicismo. Podemos mencionar como factores que han posibilitado ese influjo la liberación moral acontecida en la sociedad española, la nueva situación social, política y económica, el papel desempeñado por los medios de comunicación de masas, las relaciones industriales y comerciales establecidas entre España y los países de habla anglosajona, el cine, la moda y la música que se consumen en España, el deporte, el aumento del turismo de procedencia anglosajona, los avances técnicos - mayormente relativos al campo de la informática - puestos al alcance del ciudadano medio, etc. Todo ello sin olvidar el papel que desempeña la lengua inglesa en el curriculum educativo español a finales del siglo XX. Su aprendizaje comienza, siguiendo criterios pedagógicos, a una edad cada vez más temprana y adquiere progresivamente un mayor peso dentro de nuestro sistema educativo. También son frecuentes los viajes a Irlanda, Gran Bretaña o los Estados Unidos con el principal objetivo de aprender in situ la lengua inglesa.

Medina López enmarca el tema del influjo lingüístico del inglés sobre el español dentro de un proceso de transculturización de carácter social: "Las irrupciones del inglés en la lengua española representan una manifestación más de los usos, costumbres y actitudes del modo de vida británico o norteamericano" (1994: 8). En principio, cuanto mayor sea el grado de americanización de una sociedad, mayor será el número de anglicismos que utilizarán sus hablantes.

Sabemos que no todos los ámbitos y registros de la lengua son igualmente permeables a los anglicismos. Lorenzo recuerda que existen diferentes grados de tolerancia dependiendo de la profesión o nivel sociocultural de quien los utilice:

como la religión, la política, el ocio, los medios de comunicación, etc. 
Así, a un economista no le importa oir ni usar expresiones como cash flow, Wall Street, joint venture, insider trading, holding o marketing y docenas más, para las cuales se han propuesto, sin mucha perseverancia, diversas traducciones. Pero usados estos términos fuera del ámbito profesional pasarían por pretenciosas pedanterías indignas de gente civilizada. (Lorenzo 1995: 171)

Sin embargo, no es menos cierto que la sociedad actual está obligando al ciudadano medio a familiarizarse con distintos ámbitos que años atrás le resultaban completamente desconocidos. Hoy en día vivimos un momento histórico en el que la informática, dominada también por un país anglófono, juega un papel esencial como herramienta de trabajo para un gran sector de la población. Consecuentemente hemos adoptado anglicismos como password, floppy disk, moden, CD-rom, chip, E-mail, microsoft, windows, word, wordperfect, P.C., login log out, internet, etc., necesarios para nombrar nuevas realidades que, como bien señala Pratt (1980: 88) ya vienen provistas de su etiqueta lingüística y que, muy frecuentemente, no son de fácil traducción. En principio estos términos fueron utilizados exclusivamente por programadores informáticos o ingenieros de telecomunicaciones ${ }^{27}$ pero debido a la frecuente utilización de ordenadores por un público cada vez más amplio ya no se perciben como "pedanterías indignas de gente civilizada" por haber conseguido llegar a formar parte del lenguaje cotidiano de un gran número de personas. Incluso se puede llegar a producir el efecto contrario. Ciertos anglicismos están tan asentados en el idioma que la recuperación del término español puede llegar a producir extrañeza e incluso puede ser considerado un signo de pedantería: véase el caso de marketing y mercadotecnia.

Los factores económicos, políticos y sociales que surgieron después de la Segunda Guerra Mundial y que se han venido consolidando hasta nuestros días han convertido la influencia angloamericana en la más intensa de las sufridas por la lengua española ${ }^{28}$, y todas las lenguas romances, a lo largo de su historia:

\footnotetext{
${ }^{27}$ Meillet (1936) (1952) fue el primer lingüista en señalar que los préstamos entran a través de langues spéciales y que posteriormente algunos llegan a la langue comun.

${ }^{28}$ Excepción hecha de la influencia latina, determinante para la evolución de las lenguas romances.
} 
Of all the external forces which have affected the Romance group individually or collectively, the contemporary English influence is in many ways the most striking of all. So important has it grown during the past decade that it has eclipsed in number of borrowed lexemes and in terms of sociocultural repercussions all the inter-Romance contacts taken together. (Hope 1980: 278)

Sin embargo, a la hora de contrastar este influjo con otros fenómenos de carácter sociolingüístico en situaciones de lenguas en contacto, como pueden ser el bilingüismo, la diglosia, el cambio de código, el multilingüismo, etc., debemos destacar que la influencia angloamericana en las lenguas europeas - francés, italiano, portugués, español, etc. - no pasa de pertenecer a lo que ya Bloomfield había denominado préstamo ${ }^{29}$ cultural. Este autor diferenciaba entre dialect borrowing y cultural borrowing: "Within the sphere of borrowing, we distinguish between dialect borrowing, where the borrowed features come from within the same speech area (...), and cultural borrowing, where the borrowed features come from a different language" (1933: 444).

Bloomfield engloba el concepto de préstamo cultural dentro del fenómeno extralingüístico de la difusión cultural: las técnicas, los objetos o los hábitos de las comunidades más desarrolladas suelen ser adquiridos por las sociedades que entran en contacto con ellas, dando lugar a la aparición de nuevos términos ${ }^{30}$. La actual intensidad del préstamo cultural y sus componentes económicos, políticos y sociales ha llevado a que ciertos estudiosos franceses de carácter purista - vease Etiemble (1964) - consideren este fenómeno no como un préstamo cultural propiamente dicho sino como una colonización cultural.

\footnotetext{
${ }^{29}$ El concepto de préstamo es más amplio que el de anglicismo ya que se refiere a todo elemento lingüístico que un idioma toma de otro, bien en su forma originaria bien adaptado a las características de la lengua receptora. El grado de adaptación dependerá, entre otros factores, de la familiaridad que tengan los hablantes con el idioma del que proviene el préstamo.

${ }^{30}$ Rodríguez destaca que la intensidad del influjo angloamericano en muchos países del mundo y su creciente uniformidad relativiza la distinción entre dialect borrowing y cultural borrowing: "the intense cultural contacts of modern times diminish distances to such an extent that the old Bloomfieldian dichotomy between cultural and intimate borrowings has lost part of its validity. In light of this, one should not be surprised if further research came to reveal that the large body of English terms found in present-day Peninsular Spanish does not differ significantly from that found in other compilations done in countries of the Southern Hemisphere such as Argentina or Chile" (1999: 110).
} 


\section{4. - DIFERENTES POSTURAS SOBRE LA ANGLOMANÍA Y LOS ANGLICISMOS}

Ya hemos mencionado en este trabajo la acentuada tendencia al purismo lingüístico que caracterizó los primeros años del régimen franquista. Son representativas de esta época multitud de obras de marcado carácter ideológico y de poco valor filológico $^{31}$ que, en un tono exaltado, defienden el idioma español de los ataques de la lengua inglesa. Gómez Capúz (1998: 1294) distingue, dentro de lo que denomina la tradición académica ${ }^{32}$, tres tipos de trabajos:

1 - Defensas del idioma: artículos breves donde se describe la penosa situación del idioma español y se proponen medidas para solucionar el problema. Podemos citar como ejemplos dos artículos publicados en las actas del Cuarto congreso de academias de la lengua española (1964): "Los neologismos y su peligro" de Alcalá y "El estudio de las expresiones técnicas y científicas" de Alfonso.

2 - Breves diccionarios de anglicismos no aceptados por el Diccionario de la Real Academia Española de la Lengua que presentan la voz española recomendada para evitar el extranjerismo ${ }^{33}$. En este ámbito podemos destacar el trabajo de Salas "Extranjerismos innecesarios con sus correspondientes equivalencias españolas" o de Arango "Nuevos anglicismos en el español peninsular".

3 - Monografías de palabras de origen inglés en las que se describe la historia del término estudiado y las implicaciones culturales que conlleva su uso. Sirva como ejemplo de este tipo de estudios el artículo de Echevarría "Líder: anglicismo de cambio semántico en la América española”.

\footnotetext{
${ }^{31}$ Makiel (1968) destaca que la mayor parte de estos trabajos no han sido llevado a cabo por filólogos cualificados sino por aficionados al tema.

32 Gómez habla de la tradición académica debido a que muchos de estos artículos han visto la luz en los diferentes congresos de academias de la lengua española celebrados durante los años cincuenta.

${ }^{33} \mathrm{El}$ término extranjerismo tiene un cierto matiz despectivo. Tradicionalmente se han considerado como tales las voces foráneas que no habían alcanzado un determinado grado de integración lingüística.
} 
El espíritu combativo de estos trabajos pasa rápidamente del ámbito académico en el que habían surgido a la prensa de la época, dando lugar a encendidos artículos periodísticos sobre el tema de los anglicismos en español que solían terminar con una arenga a la defensa de la supuesta pureza de la lengua española frente a la contaminación anglicista.

En este contexto Emilio Lorenzo, académico de reconocido prestigio, publica en 1955 el primer trabajo que trata el tema de una manera rigurosa y siguiendo criterios filológicos. Contrariamente a la opinión de muchos de sus coetáneos afirma no ver los peligros que se estaban señalando y manifiesta su confianza en la capacidad de asimilación de nuevas voces de la lengua española. Incluso llega más lejos al destacar las ventajas que supone la influencia de unas lenguas sobre otras:

Tenemos confianza en el mecanismo lingüístico español, sometido ahora tan violentamente a prueba. Tiempos ha habido - la época normanda en Inglaterra, el siglo XVIII en Alemania - en que una lengua nacional ha estado a punto de claudicar ante el poder arrollador de otra extranjera. Ni el momento actual español reviste la gravedad de los períodos históricos citados ni los efectos posteriores de dichas invasiones idiomáticas dan motivo para alarmarse. De la dominación normanda en Inglaterra a partir de la batalla de Hastings resultó un enriquecimiento tal de la vieja lengua anglosajona, que ha convertido a ésta, a pesar de su anacronismo ortográfico, en uno de los más flexibles sistemas de expresión con que cuenta el mundo. (1996: 85)

Lorenzo recuerda insistentemente en sus trabajos $(1955,1995,1996)$ la génesis de la lengua inglesa destacando su capacidad omnívora para asimilar todo tipo de préstamos ya sean léxicos, sintácticos o giros idiomáticos ${ }^{34}$ y atribuye su actual hegemonía a la capacidad de asimilación de elementos de distinto origen ${ }^{35}$ :

\footnotetext{
${ }^{34}$ En "Anglicismos" Lorenzo defiende que, factores económicos y políticos aparte, la lengua inglesa debe su preponderancia a la capacidad de asimilación e integración de elementos de diferente origen "que le confieren rasgos universales y difuminan los perfiles más salientes de su ya remota vinculación germánica" (1995: 166).

${ }^{35}$ Wolfgang Viereck (1988: 141) no comparte esta opinión y aunque reconoce que la capacidad de integración de la lengua inglesa ha ayudado a su consolidación internacional, atribuye su auge a razones histórico-políticas.
} 
¿Qué es el inglés, en rigor, sino un sistema lingüístico lleno de impurezas bien asimiladas procedentes de todas las lenguas del planeta? Precisamente esa capacidad de integración es la clave de su hegemonía, no siempre deliberadamente buscada, pero tampoco rehuida, en el mercado actual de las comunicaciones humanas, sean culturales, políticas, comerciales o meramente de circunstancia. (1996: 14)

En Anglicismos Hispánicos (1996) Lorenzo mantiene la postura expuesta en su primera obra, cuarenta y un años anterior, y vuelve a recordar la fertilización léxica de nuestra lengua llevada a cabo por la influencia árabe o las palabras de Unamuno: "Meter palabras nuevas, haya o no otras que las reemplacen, es meter nuevos matices de ideas." No obstante menciona algunos problemas que la lengua española puede y debe solucionar. El primero y principal es de carácter cuantivativo: "consiste en la abrumadora penetración, numéricamente sin precedentes, de términos ingleses discutiblemente necesarios. Los mismos angloparlantes se cuestionan a veces si semejante profusión terminológica responde a una necesidad o es pura pirotecnia verbal" (1996: 19). El segundo problema se refiere a la diversidad de soluciones léxicas y fonéticas adoptadas para cada uno de los préstamos tomados del inglés.

Aun reconociendo los mencionados problemas prefiere constatar la magnitud del fenómeno en el plano internacional dentro de lo que hemos dado en denominar la aldea global y considerar las ventajas que conlleva "como portador de todos los avances de una civilización orientada al progreso constante e indefinido" (1995: 166). Lorenzo reproduce en su última obra, publicada en el año 1996, el diagnóstico de la situación que ya había planteado en 1955:

Frente a los extranjerismos idiomáticos de todo orden, el peligro no estriba en dejarlos entrar, sino en el riesgo, que hoy creemos infundado, de que la lengua deudora no sepa rechazar lo superfluo ni depurar o encasillar lo fértil o necesario en su idioma (...) (1955: 96)

Lapesa es otro de los estudiosos que aborda el tema desde un punto de vista filológico, analizando aspectos como la acomodación fonológica de los anglicismos 
léxicos de origen no grecolatino ${ }^{36}$ o el género y la formación del plural en los extranjerismos. Para explicar el fenómeno del anglicismo también recurre a la historia de la lengua española destacando el influjo latino a la hora de establecer las directrices fonéticas del futuro romance español:

El español de nuestros días no ha quedado al margen de la tendencia mundial que sacrifica lo peculiar en aras de lo supranacional y uniforme. En mayor o menor medida, todas las lenguas cultas de hoy se internacionalizan y a la vez pierden carácter. El hecho no es enteramente nuevo, pues tiene precedentes en la secular presión latinista, herencia común para toda la civilización occidental. (1963: 200)

Su concepción abierta a los influjos de otras lenguas no le impide rechazar los “anglicismos inútiles" ya abundantes en la radio y la televisión de su época ${ }^{37}$. Lázaro Carreter comparte esa preocupación y culpa a los medios de comunicación de masas de no ser cuidadosos con el idioma: "La nueva sociedad es mucho menos literaria que la de antaño, sus modelos lingüísticos no suelen ser, o no lo son tanto, los grandes escritores multitudinariamente desconocidos, sino la prensa y los programas de radio y televisión" (en Alonso 1996: 10). Esta opinión es compartida por la mayor parte de los académicos, que muestran su disconformidad con la actitud, muy común en nuestros días, de ciertos periodistas que intentan impresionar al receptor mediante el abuso de anglicismos que resultan inteligibles para el ciudadano medio pero parecen denotar un perfecto dominio de la materia por parte del hablante. Así Zamora Vicente señala: "Estoy a favor de una innovación fructífera, provechosa, (...), contra lo que protesto y protestaré siempre, es contra la actitud beatona del semiculto engreído por el hecho de salpicar su charla hueca de palabras extranjeras" (en Alonso 1996: 10).

\footnotetext{
36 Lapesa (1963: 197) destaca que los anglicismos de raíz grecolatina - como sofisticado o memorizar - se asimilan más fácilmente que los de raíz no grecolatina: hall, clip, ticket, etc.

${ }^{37}$ Las noticias difundidas por la prensa, la radio y la televisión son una inagotable fuente de anglicismos: "No es un secreto para nadie que la mayor parte de las noticias que circulan por el mundo que llamamos occidental se originan y distribuyen en agencias que tienen por lengua el inglés. (...) Incluso con la costumbre ahora extendida de presentar una mescolanza de informaciones descrita como "resumen de agencias" es fácil detectar, si se tiene cierta costumbre, la lengua en que se han originado, tanto más si la noticia es muy reciente o importante, o ambas cosas a la vez, pues entonces opera el principio nunca promulgado ni desobedecido de que la prontitud debe prevalecer sobre los primores de estilo, lo cual es una invitación a la chapuza del traductor apremiado" (Lorenzo 1987: 72).
} 
El tema ha traído consigo que la agencia EFE haya decidido editar un Manual de Español Urgente - acompañado de boletines quincenales - destinado a personas que desempeñan un papel importante en la difusión de usos lingüísticos, cuyo objetivo es resolver las dudas que se planteen a la hora de redactar una noticia. Las palabras del director de la agencia EFE en 1992 nos vuelven a recordar los dos principales problemas a los que parece enfrentarse el español actual, ya comentados en el apartado 1.2.2:

El propósito principal que anima al Departamento de Español Urgente de la Agencia EFE es evitar la dispersión lingüística del español y enfrentarnos a la invasión indiscriminada de neologismos, sobre todo, de los anglicismos que saturan nuestra lengua, tanto el lenguaje técnico como el habla popular. (1992: 223)

A pesar de los continuos llamamientos, incluso desde el propio sector periodístico, para evitar el abuso de anglicismos en los medios de comunicación de masas la realidad nos muestra que su efecto ha sido muy modesto, por no considerarlo como nulo. Este hecho puede deberse, al menos en parte, a que la tradicional dicotomía entre anglicismos necesarios y anglicismos innecesarios o de lujo dista de ser clara ${ }^{38}$.

Dámaso Alonso (1981: 425) establece tres condiciones para considerar necesaria la introducción de un anglicismo en la lengua española: no tener equivalente en castellano, ser fácilmente pronunciable para los hablantes y ser de uso común en todos los países hispanohablantes. Llorente Maldonado muestra una actitud más abierta y no establece condiciones tan restrictivas para aceptar los anglicismos:

La lengua se ha comportado de forma natural y correcta al admitir todas estas palabras y darles carta de naturaleza, hasta el punto de hacernos dudar de su carácter foráneo. Estas palabras eran necesarias, o bien porque servían para designar nuevos conceptos, nuevas realidades o nuevas técnicas, o bien porque resultaban más expresivas o menos equívocas que las correspondientes palabras patrimoniales. (en Sánchez Macarro 1993: 24)

\footnotetext{
${ }^{38}$ Lapesa (1963: 205) destaca que la Real Academia Española siempre ha tenido un talante mucho más abierto con los neologismos que las dos Academias que le precedieron y le sirvieron como modelo: la de la Crusca y la Francesa.
} 
En El neologismo necesario, publicado por la agencia EFE, los extranjerismos de raíz no grecolatina se consideran doblemente rechazables:

Toda lengua tiene una base fonética, morfológica y sintáctica, y la nuestra es grecolatina; el préstamo será tanto menos rechazable cuanto más se aproxime a esta base: humor es un anglicismo fácilmente asimilado por el español; por el contrario, préstamos herméticos del tipo cash flow son doblemente censurables. En primer lugar, son de difícil pronunciación para el español medio y en segundo lugar, porque ese mismo lector difícilmente va a entenderlo; en cambio sí entendería la voz española liquidez o efectivo. (1992: 8)

Por otra parte, Lázaro Carreter (1987: 35-36) y (1992: 38-44) establece una distinción entre préstamos técnicos y préstamos no técnicos. Los primeros son mayormente necesarios, aunque en ocasiones recomienda su traducción por designar realidades desconocidas en la cultura y la lengua receptora. Dentro de los préstamos no técnicos admite que, en ocasiones, el matiz diferencial - marcado por la novedad, especialización semántica, prestigio, etc.- puede constituir un motivo que haga necesario el préstamo. Cita como ejemplos anglicismos como bacon donde al matiz de novedad se une el hecho de que este producto presenta vetas y un corte característico, o bafle que, además de reflejar el hecho de que dicho aparato está protegido por una pantalla, conlleva un matiz de prestigio. Sin embargo muestra su rechazo hacia anglicismos no técnicos que considera inútiles y cita como ejemplos campus, master, curricular, etc.

Goddard (1980: 4) señala que el hablante utiliza en muchas ocasiones la voz foránea por considerarla más eficaz que la opción que se le propone en su idioma materno y que, en muchos casos, no deja de ser un circumloquio: "The objections of the purists to borrowings made by others will be ineffectual unless the alternative which they propose is linguistically more efficient than the loans to which they take exception."

Existen autores que desde una postura extrema de liberalismo lingüístico ponen en duda la distinción entre préstamo necesario y préstamo de lujo por estar basada en criterios extralingüísticos y aceptan cualquier préstamo que sea utilizado por los hablantes respondiendo a criterios de subjetividad, afectividad o expresividad: "We may regard it as 
an axiom that each and every word borrowed is taken over for a reason which seems good and sufficient to the borrower" (Gray 1950: 130).

\section{5. - EL CONCEPTO DE ANGLICISMO}

El concepto de anglicismo tampoco resulta de fácil delimitación. Si recurrimos a la información que nos proporcionan distintas obras lexicográficas españolas podemos encontrarnos con descripciones extremadamente sencillas que no responden a la complejidad del fenómeno. El Diccionario de la Real Academia Española (1992) propone las siguientes definiciones:

1. Giro o modo de hablar propio de la lengua inglesa. 2. Vocablo o giro de esa lengua empleado en otra. 3. Empleo de vocablos o giros ingleses en distintos idiomas.

En el Diccionario de uso del español, María Moliner (1989) da una definición más escueta: "palabra o expresión inglesa usada en otra lengua”. El Diccionario Salamanca de la lengua española (1996) dice que un anglicismo es una "palabra o expresión procedente de la lengua inglesa usada en otras lenguas”. Por su parte, diccionarios más específicos suelen proponer definiciones muy similares: el Diccionario de términos filológicos (1973) considera anglicismo la "palabra de procedencia inglesa" y el Diccionario de lingüística (1979) dice que "se denomina anglicismo todo préstamo de origen inglés".

Las anteriores definiciones dan lugar a numerosos problemas, algunos de los cuales pasamos a examinar a continuación. En primer lugar, todas ellas, excepto la del DRAE, parecen referirse exclusivamente al influjo léxico ejercido por el inglés sobre otras lenguas, olvidando, por ejemplo, la frecuente influencia de las estructuras sintácticas de la lengua inglesa sobre la española ${ }^{39}$.

\footnotetext{
${ }^{39}$ Medina López (1996: 41) destaca como principal influencia sintáctica atribuible al inglés la voz pasiva con el verbo ser, construcción que se ha convertido en habitual en los textos periodísticos: el presidente fue visto cenando en un restaurante. También menciona, dentro de una amplia concepción de la sintaxis, ciertos uso adverbiales (Inmediatamente de ocurrir el accidente), preposicionales (consiste de) e incluso morfológicos como la formación de plurales: campings, clubes, jets, etc.
} 
El segundo problema que plantean se refiere a las dificultades etimológicas existentes en el análisis de los anglicismos. La capacidad léxica del inglés para asimilar voces de muy distinta procedencia, anteriormente comentada, hace que resulte muy difícil la identificación de numerosos anglicismos. Lorenzo (1996) señala que, por intermediación de la lengua inglesa, el español ha adquirido voces de procedencia tan variada como mandolina (Italia), perestroika (Rusia), bitter (Holanda), déja vu (Francia), appartheid (Africa), quorum (latín), curry (India), samurai (Japón), etc. ¿Pueden considerarse esas voces como anglicismos? Para responder a esa pregunta es necesario introducir la distinción propuesta por Pratt (1980) entre el llamado étimo último y el étimo inmediato. Pongamos el ejemplo de la palabra té, considerada por el propio Pratt como galicismo. El étimo último de esta voz es el chino - es decir, el chino es el idioma que originariamente sumistra este término al inglés, francés, alemán, español, etc.- mientras que el étimo inmediato para el español sería, según Pratt, el francés: en un período histórico comprendido entre el siglo XVIII y el XIX el español ha establecido contacto con el francés del que ha tomado este término ${ }^{40}$. Teniendo en cuenta esa diferenciación Pratt (1980: 155) propone la siguiente definición de anglicismo: "Un anglicismo es un elemento lingüístico, o grupo de los mismos, que se emplea en el castellano peninsular contemporáneo ${ }^{41}$ y que tiene como étimo inmediato un modelo inglés."

Las anteriores definiciones de anglicismo parecen limitarse a señalar la influencia de carácter lingüístico que el inglés ejerce sobre otras lenguas. No obstante, hay autores que proponen un marco de estudio mucho más amplio de carácter sociolingüístico al considerar que el anglicismo lingüístico es una manifestación más de la invasión pacífica de usos, costumbres, actitudes y tradiciones mayoritariamente de origen norteamericano. Así el tema rebasaría el campo de la lingüística propiamente dicho y se convertiría en materia de estudio sociolingüístico.

No cabe duda de que actualmente la sociedad española toma el modelo de vida americano como referente en numerosos campos: organización empresarial, tecnología, medios de comunicación, moda, ocio, etc. e importa de ella su forma de hacer las cosas.

${ }^{40} \mathrm{El}$ análisis propuesto por Pratt presta una gran atención a la historia particular de cada palabra. Cuando no existen datos lingüísticos que certifiquen el origen del préstamo, recurre a circunstancias extralingüísticas para explicar la adopción del extranjerismo.

${ }^{41} \mathrm{Su}$ estudio se limita al ámbito geográfico del español peninsular. 
Este fenómeno ha sido denominado anglomanía ${ }^{42}$ por diferentes estudiosos del tema, término que lleva consigo un matiz claramente despectivo: propensión a considerar como positivo todo lo que proviene del mundo anglosajón. La Real Academia Española de la Lengua lo define como:

1. f. afectación en imitar las costumbres inglesas. 2. Afectación en emplear anglicismos.

Pratt (1980) considera que el setenta por ciento de los casos de anglicismos responden a la necesidad de rellenar el vacío ${ }^{43}$ que produce en el idioma receptor del préstamo la aparición de nuevos inventos, técnicas o costumbres. Bajo el influjo angloamericano adoptamos a la vez la costumbre o el objeto importado y el término que lo designa. Lorenzo pone como ejemplo el caso de la organización universitaria considerando que "tan anglicismos nos resultan los términos departamento, créditos, postgraduados, campus, etc. como los conceptos que designan" (1995: 166).

Atendiendo a las anteriores consideraciones Emilio Lorenzo, que también ha sido pionero en enlazar la vertiente lingüística y social del tema del anglicismo, propone una nueva definición de este término:

Podría concebirse una mayor dimensión del significado del término "anglicismo" sin salirse del ámbito general de la transculturización, para incluir en él hechos que no están marcados por un distintivo lingüístico especial, pero que revelan actitudes y comportamientos en la sociedad receptora que no hubieran existido sin la influencia irradiada por lo anglosajón, (...) ya sea la adopción de hábitos de conducta ajenos, o distantes e inaccesibles para los partidarios, siempre en mayoría, de la tradición inmutable. (1995: 167)

\footnotetext{
${ }^{42}$ Riquelme prefiere utilizar el término anglismo: "A ese influjo de la cultura anglosajona en las formas de vida, gestos, actitudes y modas es al que denominamos anglismo" (1998: 55).

${ }^{43}$ Hope denomina ecological hole al vacío lingüístico existente en la lengua receptora del préstamo: "Such borrowings fill an ecological hole (Hope, Pratt) of the language, in the sense that there is no alternative expression when they first appear. Since many of those borrowings designate objects, the speaker tends to establish a strong bond between the name and its referent, often thinking that the foreign term is a real name, as if it were a trade-name" (Rodríguez 1996: 110).
} 


\subsection{1. - Clasificación del anglicismo léxico ${ }^{44}$}

En el tercer capítulo de su libro El anglicismo en el español actual Medina López lleva a cabo una revisión de las distintas clasificaciones propuestas para el estudio del anglicismo léxico ${ }^{45}$ a lo largo de los últimos treinta años. Comienza su recorrido recordando la distinción establecida por Alfaro en su diccionario de anglicismos, distinción que posee muy poco valor filológico pero que refleja de una manera clara una corriente de pensamiento que ha caracterizado muchos estudios sobre el tema:

1 - Anglicismos de lenguaje superfluos. Viciosos e injustificados, que son la mayoría.

2 - Extranjerismos y neologismos. Pueden y deben adaptarse para enriquecer el idioma ya que no tienen equivalente en castellano. Su formación sigue las normas del español, aunque con la influencia determinante del francés. (1970: 19)

Posteriormente Medina pasa a examinar una serie de trabajos, de mayor valor filológico, que han clasificado los materiales léxicos estudiados ${ }^{46}$ atendiendo principalmente a dos criterios: frecuencia de uso de los anglicismos y pautas lingüísticas adoptadas en su estudio. Las obras que atienden a los criterios relativos a la frecuencia de uso - Lope Blanch (1970), Quilis (1984) López Morales (1987) - distinguen entre anglicismos de uso general: bar, boxeador, pijama, etc., anglicismos muy usuales: anorak, block, clip, etc., anglicismos de uso medio: chocar, grill, round, etc., anglicismos

\footnotetext{
${ }^{44}$ En este apartado hemos decidido limitarnos al estudio del anglicismo léxico por ser el más perceptible en el idioma español y el que ha recibido una mayor atención por parte de los estudiosos del tema. Sin embargo, no debemos olvidar que existen otros tipos de anglicismos como el anglicismo gráfico - Loli's bar - anglicismo fónico - pub, compact disk - anglicismo morfológico - boys, bebidas light - o anglicismo sintáctico - lava tus manos con Sanex. Sánchez Macarro (1993) ha llevado a cabo una exhaustiva clasificación de los diferentes tipos de anglicismos existentes en español en el artículo: "La invasión del anglicismo en el español contemporáneo."

${ }^{45}$ Medina López define el anglicismo léxico como "la influencia ejercida por la lengua inglesa en el terreno del vocabulario (o componente léxico) de una lengua, con variadas manifestaciones (puede incorporar nuevos significados en la lengua receptora, matiza o añade otros ya existentes, calca expresiones en su forma, etc.)" (1996: 20).

${ }^{46}$ La mayor parte de los trabajos que vamos a mencionar han obtenido los datos en los que se basan a través de diferentes encuestas realizadas a hablantes en distintos países hispano hablantes: Lope Blanch (1977) examina el habla culta de México, Quilis (1984) el habla de Madrid, López
} 
poco usados: clown, chut, niki, etc. y anglicismos esporádicos: cardigan, reportero, crack, etc. ${ }^{47}$

Dentro de las clasificaciones que atienden a criterios lingüísticos se menciona la distinción establecida por Pratt (1980) entre étimo último y étimo inmediato (véase el apartado 1.5.) la diferenciación entre anglicismo léxico y préstamo integrado ${ }^{48}$ de Gimeno y Gimeno (1991) y la clasificación establecida por Emilio Lorenzo (1987) en la Primera reunión de academias de la lengua española sobre el lenguaje y los medios de comunicación y que pasamos a resumir a continuación. En ella se distinguen cinco tipos de anglicimos:

1 - Anglicismos crudos - palabras o expresiones que mantienen en español la grafía inglesa y un reflejo de la pronunciación originaria más o menos fonético: hall, hobby, golf, lord, lunch, etc.

2 - Anglicismos en período de aclimatación - en ellos bien la grafía bien la pronunciación han ido adaptándose a las condiciones del español: fútbol, film(e), folclore, etc.

3 - Anglicismos totalmente asimilados - términos plenamente incorporados en la lengua española: bote, inglés, suéter, tenis, etc.

4 - Calcos - adaptaciones correspondientes a conceptos no reconocidos o desconocidos por el hablante: relaciones públicas, trabajar duro, perrito caliente, rascacielos, etc.

5 - Calcos semánticos - voces españolas que debido a su semejanza con otras inglesas adquieren nuevas acepciones: romance "amoríos", habilidad “competencia”, audiencia "público", etc.

Morales (1987) el habla de San Juan de Puerto Rico, Vaquero (1990) estudia la prensa de San Juan de Puerto Rico, etc.

${ }^{47}$ Los anglicismos aquí seleccionados han sido sacados del estudio de Antonio Quilis (1984) sobre el habla culta de Madrid.

${ }^{48}$ Según Gimeno y Gimeno (1991: 747) el anglicismo léxico "caracterizaría bien la interferencia, bien el cambio de código (fluido o señalizado), bien el préstamo momentáneo" mientras que se habla de préstamo integrado cuando procede considerarlo como parte de la gramática social de la comunidad de habla "en la medida en que el préstamo conlleva una integración lingüística y social del modelo." 


\subsection{2. - Vías de entrada}

Para llegar a alcanzar la abundancia de que disfrutan en la actualidad los anglicismos se han servido de numerosas vías de entrada. Tomando como base dos estudios sobre la penetración de anglicismos en el francés (Pergnier 1989) y el italiano (Rando 1973), Gómez Capúz (1995: 270) establece seis vías de entrada:

1 - Los medios de comunicación de masas. Como ya hemos comentado anteriormente (véase el apartado 1.4.) los medios de comunicación cuentan con un enorme poder para popularizar términos en un breve período de tiempo: recuérdese el reciente caso de las stock options (opciones sobre acciones). La prensa, la radio y la televisión, cada vez más caracterizadas por seguir el patrón marcado por los Estados Unidos, presentan modelos lingüísticos que posteriormente se reflejan en el uso que hacen los hablantes del idioma.

2 - Los medios de comunicación privados dirigidos básicamente al público juvenil. Países anglófonos como los Estados Unidos o el Reino Unido dominan la industria del ocio: música, cine, comics, televisión, etc. España importa los productos originarios - la cadena televisiva MTV o la revista Rolling Stone - o desarrolla sus propios productos imitando a los originales. Riquelme nos recuerda la procedencia norteamericana de las populares radio-fórmulas:

El origen de nuestros Cuarenta Principales o Radio 10 se encuentra en torno a 1952, cuando se detecta el gusto de los adolescentes y de los jóvenes por repetir en las sinfonolas de los bares las mismas canciones; las sinfonolas eran aquellas máquinas tocadiscos instaladas en los establecimientos destinados al consumo (especialmente juvenil): bares, recreativos, etc., que funcionaban con monedas. (1998: 55) 
Este tipo de medios de comunicación han posibilitado la entrada de anglicismos como rap, teenager, beat, skinhead, show-biz, fanzine, acid-house, dance, after-hour, look, star-system, fashion, etc.

3 - El doblaje de películas en lengua inglesa. Sánchez Macarro (1993: 27) presenta una serie de ejemplos procedentes de doblajes de películas y series mayormente norteamericanas que muestran cómo términos españoles han adquirido el significado de su parónimo inglés: agresivo adquiere el significado de "dinámico", arruinar se utiliza con el significado de "echar a perder", contemplar en el sentido de "tener en cuenta, prever", ignorar significando "pasar por alto", audiencia con el significado de "público", etc. Pueden suponerse como explicaciones a este fenómeno la premura con que se llevan a cabo algunos rodajes, la ignorancia del equivalente español ${ }^{49}$, la brevedad del término inglés o la dificultad de hacer coincidir el movimiento de los labios del actor con la palabra pronunciada en castellano.

4 - Las lenguas especiales técnicas y científicas. Ya hemos comentado anteriormente cómo muchos términos comenzaban siendo utilizados en un contexto específico y posteriormente pasaban al hablante medio. Años atrás, voces como broker, dumping, holding, leasing, marketing, stock,... se consideraban coto exclusivo de economistas. Hoy en día se utilizan en el lenguaje cotidiano con una mayor profusión.

5 - Las lenguas argóticas, en especial el lenguaje de la droga ${ }^{50}$, también son una fuente de anglicismos. Flipar, engancharse, dopado, adicto, espídico,etc. son

\footnotetext{
${ }^{49}$ Las malas traducciones pueden incluso aparecer en el título de las películas: " Hace unos años se proyectó por toda España la película titulada Las fresas salvajes, con una distorsión parecida a aquella otra famosa Orquídea Salvaje. Evidentemente los traductores no sabían distinguir en inglés wild los dos sentidos de salvaje y silvestre. De igual manera y recientemente se traduce en otra cinta el inglés The Warlord como "El señor de la guerra" (warlord significa en inglés adalid, caudillo)" (Lorenzo 1996: 105).

${ }^{50}$ Rodríguez González (1994) ha publicado un artículo titulado "Anglicismos en el argot de la droga" donde se muestra la influencia del lenguaje utilizado por los consumidores de drogas ilegales en el argot español actual. Este influjo se considera una de las fuentes de renovación léxica más importantes en el lenguaje juvenil.
} 
términos de uso común para un amplio sector de la juventud y muestran claramente su procedencia inglesa. Como señala Guardia Massó (1976: 49) a partir de los años setenta Londres ha sido uno de los centros de difusión de un sistema de valores contraculturales aceptado por grandes sectores de la juventud y la lengua inglesa se convirtió durante esa época en un medio de identificación universal. Esta identificación ha sido de tal magnitud que incluso hoy en día (a finales de los años 90) una gran parte de los grupos musicales underground españoles tienen su nombre y cantan en inglés ${ }^{51}$ : Sex Museum, Dover, Onion, Red and Invisible, Sexie Sadie, Private Idaho, etc.

6 - El turismo de masas. Este fenómeno trajo consigo la aparición de numerosos establecimientos pensados para satisfacer las necesidades del turista que no siempre encontraba lo que requería en el país que estaba visitando. Así se propició la aparición en España de pubs, hamburgueserías, restaurantes vegetarianos, cadenas de supermercados 24 horas, etc. e incluso, en muchas zonas turísticas, tiendas de un producto tan británico como las fish and chips. Este cambio de hábitos sociales también se ve reflejado en el léxico del idioma español con la aparición de términos como self-service, precocinado, bacon, chopped, donut, corn-flakes, sandwich, etc.

\subsection{3. - Campos léxicos más proclives al anglicismo}

No todos los ámbitos del lenguaje son igualmente permeables a los anglicismos: mientras que en campos como la agricultura son muy poco frecuentes, en el terreno de la informática su abundancia resulta abrumadora (véase el apartado 1.3.4.). Tampoco podemos afirmar que los campos léxicos que hoy son más proclives al anglicismo vayan a seguir reflejando esa tendencia en el futuro. Ya hemos visto cómo a principios de siglo su temática se concentraba en tres ámbitos: los deportes, la vida social y los avances

\footnotetext{
${ }^{51}$ Pratt (1980: 227) sitúa los precedentes de este fenómeno de anglomanía musical en la España de los años sesenta con el surgimiento de cantantes y actores españoles con nombre inglés: Tony Leblanc (también influido por el francés), Mike Rivers (actualmente conocido como Miguel Rios) Teddy Bautista, Mary Carrillo y Andy Ventura. Incluso en esa época se llegaron a popularizar canciones en inglés como el Black is black de Los Bravos o el Get on your knees de Los Canarios.
} 
técnicos. En los años cincuenta Stone (1957) añade nuevos campos en los que encuentra un influjo angloamericano muy destacado: la literatura, la guerra, el mar, el cine, el periodismo, la tecnología, la ciencia, etc.

Quilis (1984) destaca que en el habla culta de Madrid el anglicismo predomina en los siguientes campos (ordenados de mayor a menor): el vestuario, los deportes, transportes y viajes, la casa, la alimentación, la vida social, la política y la prensa. Gaetano Rando (1987) establece para el italiano ciertas áreas temáticas afectadas por el influjo angloamericano, áreas que creemos también pueden servir para el caso español:

1 - Los deportes

2 - El cine, la radio y la televisión

3 - La música pop

4 - La economía, el comercio y la publicidad

5 - La política internacional

6 - El ámbito técnico y científico

Sin embargo, si tenemos que elegir un campo en el que el fenómeno de los anglicismos - junto al de la anglomanía - haya experimentado un mayor crecimiento en los últimos años no dudaríamos en destacar el ámbito publicitario, nombrado en cuarto lugar en la clasificación de Rando, ya que en él convergen diversos factores de naturaleza muy distinta - sociológica, económica, cultural, etc. - que facilitan la aparición de un influjo intenso.

Esta influencia resultaba muy llamativa en la publicidad de los años setenta ya que, además del consabido uso de anglicismos, en ella se presentaban ciertos valores asumidos en los Estados Unidos pero que no coincidían con la realidad social española del momento: muchos anuncios de productos de limpieza presentaban al marido con delantal ayudando en diversas labores domésticas, señores desconocidos entraban en una casa donde sólo se encontraba una mujer para demostrar la eficacia de un detergente, etc. Además "la apariencia física de los niños y jóvenes empleados en publicidad obedecía a un arquetipo sajón: rubio, alto, delgado y guapo" (Pratt 1980: 74).

En pocos terrenos de nuestra vida cotidiana tiene el influjo angloamericano un papel tan destacado como en la publicidad. Este hecho se explica tanto por las propias 
características de la lengua inglesa como por diversos condicionantes económicos y culturales. Respecto a sus características lingüísticas, comencemos por referirnos a su destacada profusión léxica, ya resaltada en 1991 por Norman Vale, presidente de la International Advertising Association, cuando declaraba que el inglés es el mejor idioma para la publicidad por "tener una palabra para todo" (en Ferrer 1994: 25). En cuanto a los condicionantes económicos únicamente destacar aquí el papel del inglés como lingua franca en el mundo publicitario, ya comentado en la introducción:

The English language has developed as a lingua franca for the advertising world. (...) Advertising specialists have to be fluent in English. Most international advertising agencies use English for their "inter office" communications. They will not hire people who have not mastered the English language. (De Mooij 1991: 5)

Además a lo largo de este trabajo comprobaremos que la propia naturaleza del acto comunicativo publicitario también contribuye a favorecer este fenómeno. Después de llevar a cabo una breve reseña histórica acerca de la evolución de la publicidad desde el siglo XVI hasta nuestros días, en el siguiente apartado examinaremos las razones más importantes que favorecen la penetración anglicista en la publicidad española.

\section{6.- EL INGLÉS EN LA PUBLICIDAD ESPAÑOLA}

\subsection{1. - El surgimiento de la publicidad moderna}

Dos de los factores decisivos en el surgimiento de la publicidad moderna ${ }^{52}$ han sido la generalización de la imprenta durante el siglo XVI y la creación de nuevos canales de difusión - periódicos, gacetas y carteles ${ }^{53}$ - llevada a cabo en el siglo XVII. La primera agencia de anuncios aparece en Francia en 1630. Un año más tarde Renaudot, responsable

\footnotetext{
${ }^{52}$ Antes de la aparición de la imprenta, la publicidad era principalmente de carácter oral: en los mercados de las ciudades importantes abundaban los vendedores que detallaban las positivas cualidades de sus productos a una audiencia formada por compradores potenciales.

${ }^{53}$ Conejero sitúa la aparición de los carteles comerciales a principios del siglo XVIII aunque reconoce la existencia de algunos precedentes en las civilizaciones griega y egipcia: "Su utilización hasta 1722 era monopolio de la Corona y la Iglesia (con fines propagandísticos) y su eficacia resultaba dudosa, dado el elevado índice de analfabetismo existente en todos los países. A partir de esa fecha, sin embargo, se reconoció su uso legal para difundir información de carácter comercial, que se aproximaría, cada vez más, a la publicidad contemporánea” (1995: 24).
} 
de esa Bureau de Adresses publica La Gazzete, periódico que ya incluía publicidad en sus páginas $^{54}$. También en 1630 aparece en Inglaterra el Daily Advertiser, primer diario dedicado exclusivamente a la publicidad. Crystal (1997: 86) destaca que en 1666 el London Gazette comenzó a publicar un suplemento con anuncios publicitarios.

A partir de mediados del siglo XVII se producirá la permanente vinculación del fenómeno publicitario con todo nuevo medio de comunicación que consiga una presencia relevante en la sociedad. La publicidad de esta temprana época era de una naturaleza muy distinta a la que podemos encontrar hoy en día caracterizándose por el uso de técnicas persuasivas muy rudimentarias y por su carácter informativo: los anuncios hacían pública la existencia de un producto que se creía necesario para un determinado número de personas. Veamos dos ejemplos.

En 1652 apareció en el Mercurius Britannicus, periódico de información general, el primer anuncio de una bebida exótica con el siguiente texto aquí traducido al español:

En Bartolomew Lane, a espaldas de la antigua Bolsa, se vende la bebida llamada café, que es una bebida sumamente medicinal y saludable y que tiene muchas excelentes virtudes: cierra el orificio del estómago, fortifica el calor interior, ayuda a la digestión, acelera el espíritu, aligera el corazón, es buena contra los ojos irritados, toses o catarros, reuma, agotamiento, jaquecas, hidropesía, gota, diarreas, mal del Rey, y muchas otras. Se vende tanto por la mañana como a las tres de la tarde. (Rey 1996: 204)

Unos años antes había aparecido en The Public Advertiser el primer anuncio de chocolate:

En la calle de Bishopsgate, junto al callejón de Queens Head, en una casa de un caballero francés, se ofrece una bebida excelente de las Antillas, llamada chocolate. Se puede comprar ya preparada para tomarse a cualquier hora y también sin preparar, a precios razonables. (Rey 1996: 204)

En esta época los diarios ingleses ven en la publicidad una fuente de ingresos que les ayudaba a superar las fuertes trabas económicas impuestas por la corona mediante una serie de impuestos como el de timbre, el de papel, etc. La publicidad comercial tal y como

\footnotetext{
${ }^{54}$ Esta información aparece de forma detallada en Breve historia de la publicidad publicado por Sanchez Guzmán en el año 1982.
} 
la entendemos hoy en día no hará su aparición hasta el siglo XIX. Después de la revolución industrial surge la necesidad de planificar diversas estrategias que resultarían imprescindibles para vender los numerosos productos elaborados en las fábricas: desde la concepción del producto o servicio se comienza a pensar en los potenciales clientes que puedan estar interesados en éste, hecho que determinará ineludiblemente su naturaleza.

El mayor cambio que introduce el siglo $\mathrm{XX}$ en este proceso se refiere a la multiplicación de los productos ofertados por las distintas empresas y al espectacular incremento del papel de los medios de comunicación de masas en la sociedad. Así, pasamos de una publicidad cuya principal preocupación residía en dar a conocer la existencia de un producto a la publicidad que dedica sus mayores esfuerzos a buscar el necesario número de clientes que posibilite la producción y posterior venta de un determinado artículo, comenzando entonces a aludirse a las ventajas psicológicas que conlleva su adquisición y creando una imagen de marca:

El comienzo de la competencia entre productos y establecimientos de similares características hará necesaria la utilización de mensajes, fotografías, anagramas y colores para ayudar al público a distinguir y recordar las diferentes marcas y nombres comerciales. Pero, por encima de todo, surgirá la necesidad de estudiar las tendencias del público para lanzar mensajes directamente "al blanco". (Conejero 1995c: 35)

\subsection{2. - La publicidad en el siglo XX: el dominio de los Estados Unidos}

El siglo XX ha consagrado la ya inequívoca vinculación entre la publicidad y el sistema económico occidental. La publicidad comercial es una de las mayores manifestaciones del sistema capitalista y es a menudo considerada como uno de los factores responsables de la actual sociedad de consumo. Ya hemos comentado con anterioridad que su función de animar al consumo ha sido comparada con la función del aceite que posibilita que un motor funcione correctamente. Dadas estas características no sorprende que los Estados Unidos, primera potencia económica mundial, haya sido a lo largo del siglo XX el país que ha servido de referencia a todo el mundo también en el ámbito publicitario, hecho que se refleja en el porcentaje de gasto dedicado por este país a la publicidad: 
During the 1950s, the proportion of gross national income devoted to advertising was much higher in the USA than anywhere else: in 1953, for example, it was 2.6 per cent, compared with 1.5 per cent in Britain. Nearly $\$ 6,000$ million were devoted to advertising in the USA in 1950, and this rapidly increased as advertisers began to see the potential of television. (Crystal 1997: 86)

La globalización económica característica de finales del siglo XX ha contribuido a incrementar el fenómeno publicitario en todo el mundo desarrollado y, a su vez, ha afianzado la supremacía de los Estados Unidos en este ámbito. Durante los años 80, debido al incremento de tamaño de los mercados, las agencias publicitarias norteamericanas establecen estrategias de alianza o absorción con otras agencias nacionales con el objetivo de aumentar su volumen de facturación y poder cubrir así el cada vez más creciente mercado internacional ${ }^{55}$. En 1987 las diez agencias más poderosas del mundo, mayormente norteamericanas, habían conseguido multiplicar su facturación llegando la primera de ellas a los 4900 millones de dólares:

LAS 10 AGENCIAS MÁS GRANDES DEL MUND
\begin{tabular}{|c|l|r|}
\hline Puesto & Agencia & $\begin{array}{l}\text { Facturación } \\
\text { internacional }\end{array}$ \\
\hline \multicolumn{3}{|c|}{ (Millones de dólares al año) } \\
\hline 1 & Young \& Rubicam & $\$ 4.905,7$ \\
2 & Saatchi \& Saatchi Advertising Worldwide & $4.609,4$ \\
3 & Backer Spielvogel Bates Worlwide & $4.068,7$ \\
4 & BBDO Worlwide & $3.664,5$ \\
5 & Ogilvy \& Mather Worlwide & $3.663,8$ \\
6 & McCann-Erikson Worlwide & $3.418,5$ \\
7 & J Walter Thompson Company & $3.221,8$ \\
8 & Lintas: Worlwide & $2.787,2$ \\
9 & D'Arcy Masius B. \& B. & $2.494,3$ \\
10 & Leo Burnet Co. & $2.461,8$ \\
\hline
\end{tabular}

\footnotetext{
$\overline{55}$ León sitúa entre 1958 y 1976 el período álgido de implantación internacional de las agencias norteamericanas más importantes: "muchas de las cuales doblaron o cuasi triplicaron su cuota de negocio en el exterior con relación a la facturación dentro de Estados Unidos (Mattelart 1990), lo que va en paralelo con el aumento de las inversiones norteamericanas exteriores que entre 1953 y 1973 se multiplicó por seis" (1996: 206).
} 
Esta estrategia expansiva no habría sido posible sin la decisiva participación de los medios de comunicación, recibiendo el espaldarazo definitivo con el auge del fenómeno televisivo convertido en el soporte predilecto de la publicidad: a finales de los años ochenta y durante la década de los noventa los canales de televisión se han multiplicado en todos los países occidentales, se ha popularizado la televisión por satélite que ofrece los mismos programas en diferentes países, aparece la televisión por cable, etc.

Como no podría ser de otra manera, la presencia de la lengua y la cultura anglosajona en los medios de comunicación de masas es muy notoria, llegando a constituir hoy en día uno de los ámbitos donde su uso es más recurrente ${ }^{57}$. Crystal señala, como ejemplo, la frecuencia con la que se utiliza la lengua inglesa en los anuncios publicitarios de los países no anglófonos, tema que, por otra parte, constituirá nuestro principal punto de atención:

As international markets grew, the "outdoor media" began to travel the world, and their prominence in virtually every town and city is now one of the most noticeable global manifestations of English language use. The English advertisements are not always more numerous, in countries where English has no special status, but they are usually the most noticeable. (1997: 86)

\subsection{3. - Razones para la penetración anglicista en la publicidad española}

Como ya hemos visto a lo largo de este trabajo, la actual preponderancia política, económica, tecnológica y cultural de los Estados Unidos a nivel internacional trae consigo una fuerte presión sobre las distintas culturas del mundo, presión que es más notable en ámbitos donde los Estados Unidos ejercen un dominio abrumador. Nosotros nos centraremos, en este apartado, en el análisis de las causas que propician el influjo lingüístico angloamericano en el lenguaje publicitario español. Sin embargo debemos ser

\footnotetext{
${ }^{56}$ Clasificación reproducida por Conejero en su libro La sistematización lingüística del lenguaje publicitario (1995: 67c).

57 Internet es un medio de comunicación de masas emergente que merece una especial consideración por la penetración que está consiguiendo en la sociedad y por su contribución a la difusión del inglés en todo el mundo. Internet aúna tecnología, consumismo e internacionalismo y en el año 2000 el ochenta por ciento de los contenidos que potencialmente ofrece a todo el planeta se presentan exclusivamente en lengua inglesa.
} 
conscientes de que no estamos hablando de un fenómeno exclusivamente español ya que, en mayor o menor medida, se trata de una tendencia internacional que ha llevado a algunos países europeos a tomar medidas legislativas para mitigar la influencia angloamericana en su idioma. En lo relativo a la publicidad, Francia ha llegado a restringir el uso de palabras extranjeras en los anuncios publicados o emitidos en su territorio (véase Lorenzo 1996: 16).

El influjo angloamericano no es idéntico ni en todos los países ni en todos los idiomas. Su mayor o menor grado de penetración depende de muy diversos factores sociolingüísticos difíciles de medir:

El grado de penetración del anglicismo depende de relaciones sociolingüísticas muy complejas y amplias, pues habría que considerar el nivel de vinculación, por ejemplo, de cada país con algún otro de lengua anglosajona, la intensidad de las relaciones comerciales, el desarrollo económico y social de cada sociedad, la importancia de los medios de comunicación, el nivel medio educativo de cada país, las relaciones históricas, etc. (Medina 1994: 8)

Intentando huir de posturas reduccionistas en un fenómeno de gran complejidad advertimos tres razones principales que ayudan a explicar la anglomanía característica de la publicidad española: aspiración internacional hacia un marketing y una publicidad global, preferencia de los hablantes hispanos por lo anglosajón y afán de originalidad en el competitivo mundo publicitario.

\subsubsection{1. - Aspiración internacional hacia un marketing y una publicidad global}

Durante los años sesenta, década en la que España comienza a incorporarse al sistema económico capitalista, se multiplica por cuatro el gasto publicitario en nuestro país (Pratt 1980: 73) confirmando así el carácter consumista de la transformada sociedad española. El creciente liberalismo económico trae consigo acuerdos internacionales que propiciaban el establecimiento de empresas multinacionales en suelo español y, a su vez, la distribución de productos originarios de esos países. Sin embargo, a partir de los años ochenta se produce un cambio muy relevante en la política de las empresas 
multinacionales: éstas no se conforman con poder exportar sus productos a otras naciones sino que, por razones puramente económicas, aspiran a homogeneizar los gustos de todos sus potenciales clientes distribuidos en multitud de países distintos.

En 1983 Theodore Lewitt publicó un artículo en la "Harvard Business Review" donde defendía la necesidad de que las grandes empresas que perseguían el éxito comercial aprendieran a funcionar viendo el mundo como un único mercado, ignorando las diferencias nacionales y vendiendo el mismo producto de la misma manera a lo largo y ancho del planeta ya que consideraba que todos los consumidores manifiestan los mismos deseos a la hora de adquirir un producto $^{58}$. Si analizamos las estrategias de marketing y las técnicas publicitarias seguidas por empresas multinacionales como CocaCola, Pepsi, Sony, Nokia o Levi's podemos concluir que existe una clara aspiración a caminar hacia un marketing y una publicidad global ${ }^{59}$ :

This global approach makes sense, according to Levitt, because consumers around the world are motivated by the same desires for modernity, quality and value. At the same time, new technology and standarized methods of production have made global marketing programmes feasible. (De Mooj 1991: 3)

Esta tendencia se ve propiciada por la aparición de ciertas situaciones ya míticas de carácter internacional difundidas por los medios de comunicación: la televisión y el cine americano han creado una serie de "mitos de alcance global que cualquier persona, ya viva en Europa o en Malasia, pueda decodificar y gustar sobremanera" (León 1996: 207). Entre ellos podemos mencionar las producciones del Hollywood clásico, la última película de Steven Spielberg o George Lucas, las sitcoms, los talkshows, etc. Estos elementos míticos posibilitan que los anuncios publicitarios puedan construir mensajes dentro de un marco fácilmente reconocible en cualquier parte del mundo:

\footnotetext{
${ }^{58}$ En 1989 Friberg (en León 1996: 206) predice los cuatro principios estratégicos básicos que deben afrontar las grandes empresas de cara al futuro: homogeneización de las campañas publicitarias a nivel mundial, reducción del exceso de capacidad, construcción de economías a escala y consideración de la competencia de ámbito internacional.

${ }^{59}$ Este fenómeno de globalización de mercados debe entenderse como una tendencia general, más acusada si cabe en productos como los tecnológicos. Valdés (1998: 195) recuerda los numerosos ejemplos de fracasos de campañas multinacionales, recogidos en diversos manuales de publicidad, por no haber considerado en su justa medida las diferencias culturales.
} 
Los ejemplos abundan hasta la extenuación y sólo mencionaremos a título de ejemplo la ingente cantidad de anuncios ambientados en pleno desierto de Arizona, con los tradicionales policías de tráfico, los gigantescos camiones, o las cantinas polvorientas, según las circunstancias creativas. (Leon 1996: 209)

A la tendencia hacia una homogeneización de los gustos y al papel unificador de la televisión y de los demás medios de comunicación de masas tenemos que añadir el papel desepeñado por las agencias publicitarias multinacionales que en un reducido número operan en todos los países del mundo desarrollado. Pratt (1980: 73) advierte que las agencias publicitarias más poderosas de España - Young and Rubicam, Leo Burnett, Ogilvy and Mather, BBDO, etc. - son multinacionales de iure y norteamericanas de facto.

Los procesos de homogeinización cultural alentados por intereses comerciales transnacionales han sido duramente criticados considerando a la publicidad como un elemento más dirigido a conseguir el mencionado objetivo uniformador y a consagrar el dominio del mundo por la superpotencia americana:

La tesis del imperialismo cultural proclama que la cultura local auténtica y tradicional en muchas partes del mundo está siendo eliminada por la oferta indiscriminada de ingentes volúmenes de anuncios y productos mediáticos, principalmente provenientes de los Estados Unidos. (Tunstall 1977: 57 en León 1996: 207)

También existe la postura contraria que considera el imperialismo económico como positivo y consustancial a la historia de la humanidad argumentando que las sociedades más avanzadas siempre han influido sobre las más atrasadas, propiciando el desarrollo de estas últimas. Desde esta perspectiva, los razonamientos proteccionistas se estiman basados en conceptos de identidad colectiva que no tienen cabida en la situación mundial actual.

\subsubsection{2 - Preferencia de los hispanohablantes por lo anglosajón}

Es bien sabido que son los propios hablantes quienes marcan los designios de un idioma, muy por encima de cualquier otro factor como la Real Academia Española de la 
Lengua o los medios de comunicación de masas ${ }^{60}$. Hoy en día podemos afirmar que éstos no muestran beligerancia, más bien todo lo contrario, hacia los anglicismos. Incluso en los casos más extremos en los que un anglicismo crudo viene a sustituir un término existentente en su propio idioma no parece producirse una postura de rechazo general: en numerosas ocasiones los hablantes se limitan a incorporar paulatinamente el nuevo término - bien adaptado al español bien en su forma originaria - a su conversación cotidiana hasta llegar a integrarlo completamente en el sistema lingüístico español después de haber pasado un período de asentamiento más o menos largo. Medina López alude a diferentes causas que explican la situación aquí descrita:

Varias han sido las razones de carácter sociolingüístico señaladas para explicar la preferencia de los hablantes por los vocablos anglosajones: estimación más de lo extranjero que lo propio, preferencia por lo novedoso, despreocupación por la pureza e integridad del idioma, etc. (1991: 122)

Este fenómeno no es exclusivamente apreciable en el uso del idioma característico de los hablantes medios sino que también afecta al discurso cotidiano de los profesionales de ámbitos tan dispares como el arte, la economía, las nuevas tecnologías, el cine o el derecho. Como hemos visto anteriormente, las lenguas especiales técnicas y científicas constituyen una importante vía de entrada para el anglicismo. En principio, estos términos se comenzaron a utilizar para designar ciertas realidades desconocidas en la cultura o en la lengua receptora pero hoy en día su uso responde, en la mayoría de los casos, a una cuestión de preferencias de los hablantes, como mostraremos en el siguiente ejemplo.

El uso de anglicismos en el derecho español adquiere una relevancia especial por el carácter taxativo, codificado y reglado de su lenguaje. En las últimas décadas, los tradicionales préstamos de procedencia latina como erga omnes, rebus sic stantibus o juris tantum se han visto superados por los anglicismos, particularmente en las ramas del derecho más proclives a sufrir el influjo angloamericano. Así, quien se adentre por las

\footnotetext{
${ }^{60}$ Uno de los ejemplos ya clásicos que pueden ilustrar este fenómeno es el término cassette, llegado al español por medio del mundo publicitario. Años atrás, la RAE había propuesto con bastante insistencia su sustitución por el vocablo español "cajita" y sin embargo nunca ha llegado a conseguir su propósito debido a la preferencia de los hablantes por el término anglosajón (véase Cardona y Fernandez 1972: 22).
} 
sendas del derecho mercantil, internacional o económico debe familiarizarse con el manejo de términos ingleses como franchising, factoring, time-sharing ${ }^{61}$, warrant, suspension of hire, treaty making power, soft law, executive agreement, trade off, free rider, etc.

No obstante, en la mayoría de los casos, existen términos autóctonos que designan con idéntica precisión el concepto que proviene del mundo angloamericano: warrant garantía, treaty making power - estado de pleno derecho, package deal-arreglo global, soft law - derecho blando, cooling off - aplazamiento, self-help - autoprotección, stock existencias, royalty - canon, manager - director o apoderado, copyright - derechos de autor, dumping - competencia desleal. El caso más notable se refiere al anglicismo leasing que, a pesar de su traducción oficial "arrendamiento financiero", prevista por Real Decreto en 1977 nunca ha dejado de denominarse por el término inglés.

Tal y como ocurre en muchos otros lenguajes especiales técnicos el creciente uso de anglicismos en el campo del derecho español no puede explicarse aludiendo a un supuesto matiz de especificidad del término empleado, como prueba el hecho de que la legislación en nuestro país recomiende el uso de términos propios de la lengua española, sino que debe recurrirse a una explicación de carácter pragmático ya que su uso responde más a menudo a una cuestión relativa a la imagen del usuario del préstamo que a una sincera razón de fidelidad al término original. Optando por el uso de los anteriores anglicismos, el hablante intenta proyectar en su discurso una imagen de cosmopolitismo o de acomodo a los conceptos del todopoderoso derecho angloamericano que poco tiene que ver con la idea de delimitar claramente el ámbito de aplicación del término empleado $^{62}$.

Así, la anglomanía se puede explicar, al menos en parte, aludiendo a un fenómeno de carácter sociológico que afecta a un gran número de hablantes: existe una tendencia

\footnotetext{
${ }^{61}$ Normalmente el hablante adapta, en mayor o menor medida, el anglicismo a su sistema fonador. Ciertas empresas captan clientes ofertándoles un sistema de multipropiedad llamado time-sharing, y es tal el grado de integración del compuesto en los puntos turísticos donde operan esas empresas, que no es infrecuente oír en las Islas Canarias la palabra híbrida tanchere, una corrupción del original acorde con el modo de articulación local, pero aún claramente vinculada al inglés.

${ }^{62}$ Se puede añadir que el uso de términos que resultan opacos para el destinatario crea además cierta distancia entre el letrado y su cliente, fenómeno que también entraría dentro del ámbito relativo a la imagen del usuario.
} 
general a imitar a quien se admira y a querer incorporarse al grupo de los que son admirados por los demás. Actualmente, la lengua inglesa se ve positivamente marcada por el prestigio inherente a cualquier estado económicamente superdesarrollado. Mediante un uso generalizado de los anglicismos crudos ciertos hablantes pretenden mostrar su deseo de ser reconocidos como pertenecientes a ese grupo.

Gómez distingue dos factores que resultan determinantes para explicar el uso de anglicismos en España: las motivaciones sociológicas asociadas a conceptos como prestigio, modernidad, eficacia, etc. y motivaciones lingüísticas como la brevedad y monosilabismo de muchas voces inglesas, la plasticidad gramatical del inglés "que permite el empleo de un mismo lexema con distintos valores categoriales: sustantivo, adjetivo, verbo" (1995: 270). Ambos factores adquieren su mayor expresión en el campo del lenguaje publicitario ya que tanto las motivaciones sociológicas asociadas al prestigio, la modernidad o la eficacia como las motivaciones lingüísticas anteriormente mencionadas ayudan a explicar el uso que el lenguaje publicitario español lleva a cabo tanto de los anglicismos como de los mensajes íntegramente escritos en lengua inglesa, tema que trataremos en profundidad en el tercer apartado de nuestro trabajo.

Existen además otros factores que propician el influjo anglicista en la sociedad española. Dentro del estudio de la publicidad multinacional, León destaca que ésta, caracterizada por el uso de referencias culturales y lingüísticas propias de los Estados Unidos, no tiene los mismos efectos en todos los países y atribuye su fácil penetración en España a la inexistencia de una conciencia fuerte de identidad como país:

No podría hablarse de que la publicidad multinacional pueda conseguir una penetración indiscriminada en todos los países; en general, aquellos países con una fuerte conciencia de la propia identidad, como pueden ser Gran Bretaña, Francia o Japón, resultan ser muy impermeables a la influencia exterior, frente a otros como España o los países latinoamericanos, aquejados históricamente de una inseguridad crónica sobre su propio ser y obrar. (León 1996: 210)

\subsubsection{3. - Afán de originalidad en el texto publicitario}

Por la propia naturaleza de este acto comunicativo, la intencionalidad debe ser siempre tenida en cuenta a la hora de llevar a cabo cualquier estudio acerca de la 
comunicación publicitaria. No debemos olvidar en ningún momento que se trata de un mensaje pagado con una dimensión pragmática muy clara: influir en la conducta de los destinatarios. El acto comunicativo publicitario está totalmente condicionado por el imperativo último de la persuasión del receptor y su afán de originalidad aparece directamente relacionado con la anterior premisa. El primer cometido del anuncio consiste en atraer la atención del desinteresado destinatario, como bien parece indicar el verbo latino advertere del que se deriva el término inglés advertising y con ese objetivo el publicista no dudará en utilizar todos los recursos, tanto lingüísticos como no lingüísticos, que considere darán buenos resultados.

El lenguaje publicitario se debe a sí mismo y las únicas normas que sigue son las que dicta el éxito o el fracaso de sus mensajes. Así recurrirá a cualquier medio lingüístico que posibilite la persuasión del receptor promoviendo todo tipo de innovaciones yuxtaposición de oraciones, creación de neologismos, empleo de frases hechas, juegos de palabras, etc. - llegando en algunas ocasiones a violar determinadas normas del lenguaje: supresión de preposiciones y artículos, uso de adjetivos con valor adverbial, transgresión de las normas ortográficas, etc. A nivel léxico, el influjo anglicista se revela como la mayor fuente de innovaciones lingüísticas que el mensaje publicitario utiliza hoy en día. Proporcionamos a continuación una clasificación de alguno de los fenómenos de renovación léxica más recurrentes en nuestro corpus de anuncios atribuibles a la presión anglicista:

- Anglicismos crudos: high-tech, dual band, outsourcing, styling, softtouch, air-active, soft air, zapping, vibracall, week-end, bodymilk, break, view, walkman, etc.

- Calcos semánticos: el más común en el mundo publicitario es el uso de la voz "alta" con el significado de "buena" o "excelente" - alta resolución, alta capacidad, seguridad, etc. También son muy frecuentes "operar" con el significado de "trabajar", "canal" con el significado de "cadena", "firma" con el sentido de "empresa" o "casa comercial", "vivo" con el significado de "directo", "alarma" con el significado de "despertador", etc. 
- Calcos: diccionario predictivo, banda dual, efecto drenaje, efecto lifting, testado, aire acondicionado, centro comercial, etc.

- Extranjerismo gráfico: Deko hogar, Neutrex, Bankinter, Comby, etc.

- Uso del genitivo anglosajón: Deward's, Pepe's, Ballantine's, Tod's, Pasarela's, etc.

- Prefijación extranjerizante: ultrarrápido, ultraplano, extralargo, provitaminas, bifunción, súper-antioxidante, autocontrol, etc.

- Sufijación extranjerizante: Stressless, cerix, Gertronics, automatic, analergic, etc.

La formación de términos compuestos, muy adecuados para describir las novedades que presentan los anuncios publicitarios, también puede resultar atribuible, al menos en parte, al influjo del inglés, idioma que muestra una gran facilidad para formar compuestos sin recurrir a la utilización de preposiciones: signal plus sarro-control fórmula, BMW Serie 5 Touring 286 caballos 8 cilindros, impresora Xerox laser color, etc.

Alba de Diego (1975: 30) considera que el uso de anglicismos en el lenguaje publicitario obedece a dos razones principales: bien cubren lagunas en el léxico de una lengua añadiendo, en ocasiones, un matiz diferencial de carácter objetivo (panty, bitter, compact disk, software, short, etc.) o bien muestran una necesidad de carácter pragmático de renovación estética o expresiva que en muchas ocasiones no buscan la permanencia en el idioma ni consiguen la aceptación por parte de la comunidad lingüística en la que pretenden establecerse: teenager, underground, indie, etc.

Sin embargo, no resulta sencillo establecer una frontera que separe claramente el objetivo concepto relativo a la especificidad del término empleado de las subjetivas necesidades de renovación estética propias de la publicidad. La abundancia de términos como compact-disk, e-mail, jeans o shorts en publicidad tiende a explicarse mediante la necesidad de nombrar nuevas realidades de carácter objetivo. Debemos tener en cuenta que, en los anteriores ejemplos, podría fácilmente recurrirse a un término español - disco 
compacto, correo electrónico, vaqueros o pantalón corto - opciones muy poco frecuentes en el discurso publicitario. Así, nos vemos inclinados a pensar que junto al matiz de especificidad, existe por parte del mundo publicitario un deseo de recurrir al anglicismo crudo para poner de manifiesto el carácter innovador del artículo publicitado. El anglicismo crudo, denominado por Pratt (1980: 226) anglicismo patente, proporciona al producto ciertas características de carácter positivo relacionadas con los conceptos de prestigio, originalidad y modernidad anteriormente mencionados. Concurren además razones estilísticas ya que los anglicismos también ayudan a proporcionar al anuncio una mayor viveza expresiva: "Through the foreign term the writer often attempts to create a foreign atmosphere, while providing the text with a freshness, a vividness and a greater authenticity" (Rodríguez 1996: 123).

\section{7. - PRESENCIA DE LA LENGUA INGLESA EN LA PUBLICIDAD ESPAÑOLA}

\subsection{1. - Objetivo de nuestro análisis}

En este apartado llevaremos a cabo un análisis de diversos anuncios publicitarios recientemente publicados en la prensa española con el propósito de conseguir dos objetivos: por una parte reflexionar acerca del número de anglicismos crudos existentes en la publicidad española y por otra parte poner de manifiesto el creciente uso de mensajes escritos en lengua inglesa para publicitar productos dirigidos a un público cuya lengua de uso común es el español.

Cada vez resulta más habitual encontrarnos con anuncios publicitarios - tanto en prensa como en radio o televisión - donde se recurre a la lengua inglesa para comunicarse con un público al que no se le presupone un conocimiento de ésta y al que generalmente no se le facilita una traducción del contenido lingüístico del texto empleado. Este hecho no se restringe a los productos que provienen de países anglosajones como en principio cabría esperar. Lorenzo (1996: 15) destaca que cualquier producto procedente de cualquier país industrializado del mundo puede recurrir, y de hecho recurre, a la lengua inglesa. Cita, a modo de ejemplo, los siguientes anuncios aparecidos en el diario "El País" 
entre el 9 y 11 de Junio de 1994: We take the world's greatest pictures (Japón), Videos XXX con Showview XXX. Made for you (Alemania), Private banking. Incredibly global, incredible Private (Suiza), Do you think it's intelligent to invest in one currency only? (Sociedad de valores multinacional).

Este fenómeno puede considerarse como una de las máximas expresiones del influjo angloamericano en nuestra sociedad ya que no se trata de la tradicional influencia anglicista sobre nuestro habitual sistema de comunicación, examinada en los apartados anteriores, sino que implica la sustitución en contextos determinados del idioma propio de uso común por otro de procedencia foránea.

La situación comunicativa que se produce cuando el emisor envía conscientemente un estímulo lingüístico al destinatario en un código que no es de uso habitual buscando conseguir su persuasión es un fenómeno que merece una minuciosa consideración. En primer lugar intentaremos poner de manifiesto la magnitud de esta circunstancia para posteriormente dedicar el apartado tercero y cuarto de este trabajo a proporcionar una explicación de carácter pragmático basada en la teoría de la relevancia de Sperber y Wilson. Antes de adentrarnos en el estudio de la publicidad convencional analizaremos el uso de anglicismos y de mensajes en lengua inglesa en un ámbito muy determinado y con unos condicionantes claramente establecidos: nos estamos refiriendo a las ofertas de empleo.

\subsection{2. - El inglés y el anglicismo en las ofertas de empleo}

En contraste con la publicidad comercial, a cuyo análisis dedicaremos la mayor parte de nuestro trabajo, los anuncios de ofertas de empleo constituyen un tipo de discurso relativamente homogéneo caracterizado principalmente por la facilidad de acceso a lo que Van Dijk y Kintsch (1983) denominan discourse topic. Tanto sus estructuras textuales globales $^{63}$ (macro y superestructuras) como el contexto en el que aparecen (suplementos

\footnotetext{
63 Van Dijk (1980) distingue dos estructuras textuales globales: la macroestructura y la superestructura. La macroestructura es una estructura semántica que organiza la estructuración local del texto y se refleja a nivel intuitivo en el uso de términos como "tema", "argumento" o "asunto". Por su parte la superestructura funciona como un esquema que ordena el contenido semántico del texto. Se citan como ejemplos de esta estructura global la estructura narrativa de un cuento, la estructura argumentativa de un discurso, etc.
} 
de negocios, trabajo o empleo) parecen indicar que este tipo de discurso presta una mayor atención a la facilidad de procesamiento que a los factores relativos a la implicación del receptor característicos de la publicidad comercial.

El influjo lingüístico angloamericano en los denominados anuncios de trabajo es de tal magnitud que nos hemos visto obligados a reducir nuestro corpus a un único suplemento de "Negocios", que es donde aparecen las ofertas de empleo privado, para evitar que el estudio resulte excesivamente tedioso. El suplemento que hemos elegido ha sido publicado el 26 de Marzo de 2000 por el diario "El País". Dividiremos nuestro análisis en dos apartados: en el primero estudiaremos principalmente el uso de anglicismos $\operatorname{crudos}^{64}$ en las ofertas de empleo y en el segundo apartado examinaremos los anuncios de trabajo íntegramente publicados en lengua inglesa.

\subsubsection{1. - Anglicismos en las ofertas de empleo}

Si consideramos que nuestro corpus, compuesto por 132 anuncios, refleja en cierta medida la situación actual del mercado laboral español, podemos deducir que los profesionales más demandados son, en orden descendiente, expertos en marketing (16 anuncios), ingenieros de telecomunicaciones ${ }^{65}$ (15 anuncios), programadores informáticos (13 anuncios) y comerciales (10 anuncios). Atendiendo a los datos extraídos de nuestro corpus podemos afirmar que más de la mitad de los trabajos demandados por las empresas están directamente relacionados con el ámbito de la informática, lo que se refleja ineludiblemente en el discurso que estos mensajes utilizan.

El número de anglicismos pertenecientes al campo de la informática resulta abrumador. Dentro de ellos podemos distinguir entre los que pueden considerarse de uso común ya que han conseguido formar parte del lenguaje cotidiano de una buena parte de

\footnotetext{
${ }^{64}$ Como hemos visto anteriormente hablamos de anglicimos crudos para referirnos a los términos que no han sufrido una acomodación morfológica o fonética destacable al sistema lingüístico español.

${ }^{65}$ Existen empresas que solicitan indistintamente programadores de informática o ingenieros de telecomunicaciones. Como nuestros objetivos son meramente estadísticos únicamente hemos contabilizado estos anuncios en uno de los dos grupos.
} 
la población - internet, Windows, CD Rom, Word, Wordperfect, página Web, chat $^{66}$, online, etc. - y los que todavía hoy pertenecen al dominio exclusivo de los informáticos. Dentro de la primera categoría el término e-mail es el único que convive con su calco español "correo electrónico". En este caso, el uso del calco ha ganado terreno en el lenguaje cotidiano aunque no ocurre lo mismo en las ofertas de empleo: muchas compañías incluyen su dirección electrónica para facilitar al interesado el contacto con la empresa demandante de personal pero en ningún anuncio de nuestro corpus se utiliza el equivalente español. Ello se debe al prestigio, imagen de modernidad y mayor brevedad de la voz inglesa (el espacio es importante en publicidad) además de a un deseo de enfatizar la distinción entre el correo electrónico y el convencional.

Los anglicismos de dominio exclusivo de los informáticos entran dentro del campo de los tecnicismos y en muchos casos no se ha previsto un calco o traducción española ${ }^{67}$. Mostramos a continuación algunos anglicismos pertenecientes al ámbito de la informática que hemos encontrado en nuestro corpus y que hemos clasificado atendiendo a su naturaleza:

sistemas operativos: Unix, Windows, etc. bases de datos: Access, Fox, Oracle, SQL Server, etc. lenguajes de programación: Visual Basic, Unix Shell Script, etc. diseño de páginas web: Servlets, Javascript, Java, Flash, Photoshop, etc. enlaces: Frame Relay, Routers, etc. servidores de aplicaciones: Silverstream, NetDynamics, Broadvision, etc. gestión de sistemas y red: Open View, Patrol, Optivity, TNG-Unicenter, etc.

Otros anglicismos informáticos presentes en nuestro corpus son: Cobol Host, AutoCad, (Computer Aided Design), microstation, Matlab, Simulink, DSP Toolboxes, etc. En general, se trata de términos acuñados bien por la compañía que crea las aplicaciones

\footnotetext{
${ }^{66}$ Chat es un anglicismo de muy reciente incorporación al léxico español. Sin embargo ya dispone de sufijos propiamente castellanos: chatear, chateando, etc. Esto implica que el término se ha aceptado como propio y que está integrado en el sistema morfológico español.

${ }^{67}$ Para un estudio en profundidad de los anglicismos relativos a la informática, véanse los trabajos de investigación de Aguado (1992) Problemas de traducción de la terminología informática en España y Gil (1986) El anglicismo en el campo de la informática.
} 
- Hewlett Packard, Microsoft, Intel, Macintosh, etc. - bien por un grupo de empresas o bien por organismos internacionales que utilizan exclusivamente la lengua inglesa como, por ejemplo, el ITU (International Telecommunications Union). La mayoría de estos vocablos, propiedad de distintas empresas, caducan con mucha rapidez debido a la continua revolución tecnológica en que estamos inmersos y no suelen llegar a calar en el idioma.

Las actividades comerciales constituyen el segundo campo en el que los anglicismos aparecen con mayor profusión. Además de voces ya incorporadas al lenguaje de uso común - marketing, stock, manager, stands, etc.- nos encontramos con anglicismos crudos que se introducen en una frase en español y que normalmente vienen a sustituir un término o circunloquio autóctono:

- $\quad$ Empresa de café precisa comerciales para vending (pág. 40) ${ }^{68}$

- Gran novedad en máquinas de vending para hostelería (pág. 37)

- Nuestro cliente, (...), desea incorporar un Jefe de Sector para su división de Retail (pág. 41)

- Total responsabilidad sobre los objetivos de budget, y la cifra de ventas (pág. 41)

- ... valorándose la experiencia en la gestión de Call Centers ${ }^{69}$, y el conocimiento del sector seguros (pág. 41)

- ... elaborará el Business Plan, creará un equipo y organizará la nueva división (pág. 42)

El creciente fenómeno del comercio electrónico, siempre denominado e-business en los anuncios examinados, también proporciona un gran número de anglicismos al aunar el área tecnológica y comercial:

- Nuestro cliente desea incorporar consultores de e-business (pág. 41)

\footnotetext{
${ }^{68}$ El número de página al que aquí hacemos referencia corresponde a la paginación del suplemento de negocios que estamos analizando.

${ }^{69}$ Este anglicismo aparece nueve veces en nuestro corpus y siempre se opta por la grafía americana centers, hecho que da cuenta del predominante influjo norteamericano en la publicidad española.
} 
- Para desarrollar proyecto en España buscamos un/a E-business marketing manager (pág. 42)

Un caso muy similar ocurre en los anuncios de consultoría para operadores de telecomunicaciones donde se utilizan anglicismos crudos como Customer care (pág. 45), Business recovery (pág. 41), Billing systems (pág. 45), Workflow (pág. 39), Assesment Center (pág. 44), Feedback $360^{\circ}$ (pág. 45), Management Audit (pág. 37), Coaching (pág. 44), etc. para dar nombre a alguno de los múltiples servicios de la compañía.

Otros anglicismos crudos que aparecen en nuestro corpus y que pertenecen a distintos campos del mundo laboral son los siguientes: maquinistas offset (pág. 38), impresión offset (pág. 46), telemarketing (pág. 46), teleperformance (pág. 38), experiencia demostrable en packaging (pág. 39), gestión de party line (pág. 44), copy corrector de pruebas (pág. 39), etc.

En el primer párrafo de este apartado ya hemos comentado que si atendemos a las estructuras textuales y al contexto en que aparecen las ofertas de empleo podemos deducir que en este particular acto comunicativo la facilidad de procesamiento tiene un mayor peso que la implicación del receptor. Sin embargo un estudio de carácter global de estos anuncios nos permite concluir que existen razones para creer que el uso de anglicismos también está desempeñando el cometido de atraer la atención del receptor, funcionando como lo que Cook (1992: 217) considera un attention grabbing device.

Los anuncios de trabajo de nuestro corpus presentan una superestructura muy similar en la que podemos distinguir cinco partes bien diferenciadas: presentación, demanda, perfil, contrapartidas y contacto. La presentación proporciona datos como el nombre de la empresa demandante de personal, su posicionamiento en el mercado, el sector que trabaja, etc. La demanda es, debido al tamaño y tipo de letra que utiliza, la parte del anuncio que más destaca. En ella se especifica el puesto que se desea cubrir. El perfil describe las funciones del futuro empleado en la empresa y los requisitos que debe cumplir. A cambio de su trabajo, la empresa ofrecerá a su empleado unas contrapartidas económicas, de formación, viajes, seguros, alojamiento, etc. Para finalizar la superestructura, los anuncios facilitan cierta información que posibilita a las personas 
interesadas en el trabajo ponerse en contacto con la empresa: dirección, teléfonos, fax, correo electrónico, etc. Veamos un ejemplo:

PRESENTACIÓN: Somos una multinacional integrada en el Grupo Telefónica, especializada en la gestión de Call centers y Teleservicios, presente en 10 países.

DEMANDA: $\quad$ Necesitamos incorporar en nuestros centros de Madrid y Getafe:

HELP-DESK Primer nivel de soporte

PERFIL: $\quad$ Nos dirigimos a jóvenes profesionales, que se incorporen a nuesta Organización para realizar Servicios de Soporte Técnico por Teléfono, con formación de Bachiller Superior o F.P. II que aporten conocimientos de: Windows 95/98 usuario avanzado, instalación y desinstalación de aplicaciones Windows y conocimientos de Internet, niveles Hardware y Software.

CONTRAPARTIDAS: Ofrecemos sueldo fijo más un atractivo sistema de comisiones. Horario de Media Jornada o Jornada Completa de lunes a viernes, contrato laboral estable con alta en la Seguridad Social e incorporación a un grato ambiente de trabajo.

CONTACTO: Las personas interesadas deberán llamar urgentemente, desde HOY DOMINGO, a los teléfonos 917406917 para Madrid y 914067717 para Getafe.

Figura 1

Además de ciertos términos pertenecientes al campo de la informática - como Call centers, Internet, Windows, Software o Hardware - podemos observar que este anuncio presenta el puesto de trabajo que se desea cubrir con un anglicismo - Help-desk que resalta tipográficamente en el cuerpo del anuncio y no clarifica las funciones que tiene que realizar el demandante de empleo. En lugar de matizar el cometido del trabajo el emisor parece concentrarse en presentar un estímulo atractivo para el destinatario tanto por la opacidad del término empleado como por su filiación anglicista. Las particulares características tipográficas de la demanda posibilitan a su vez el uso de tamaños y tipos de letra atractivos para el lector. El perfil clarificará las funciones del trabajador: en esta ocasión se trata de servicios de soporte técnico por teléfono.

El uso de anglicismos para designar diferentes puestos de trabajo es una técnica muy recurrente en los anuncios que estamos analizando: 
PRESENTACIÓN: Infogrames España, compañía líder en el sector del videojuego y software de entretenimiento en plena fase de expansión,

DEMANDA: precisa cubrir los siguiente puestos:

Product Manager para el área de deportes.

PERFIL:

Será responsable de participar en la creación de los productos, adaptar los planes de marketing internacionales al mercado español, organizar y llevar a cabo las acciones con seguimiento de presupuestos. (...)

Figura 2

PRESENTACIÓN: Grupo de empresas, sector Gran Consumo, sólidamente establecido precisa para continuar su desarrollo

DEMANDA:

PERFIL:

\section{Brand Manager}

Reportando $^{70}$ a Dirección de Marketing será responsable del diseño y puesta en práctica de las estrategias de marketing relativas a sus productos, realización de acciones promocionales, gestión de sus presupuestos, ...

Figura 3

PRESENTACIÓN: Nuestro cliente es la filial española de una de las principales compañías eléctricas alemanas (...)

DEMANDA: precisa incorporar a su sede de Madrid, profesionales que respondan a los siguientes perfiles:

\section{Controller ${ }^{71}$}

PERFIL:

en dependencia de la Dirección General, se responsabilizará de la organización y realización del control de gestión de la empresa, elaboración y seguimiento de los presupuestos, análisis financiero, de costes y resultados, supervisión de la contabilidad y elaboración del reporting interno en la compañía. (...)

Figura 4

Los ejemplos son muy numerosos: Marketing manager (pág. 53) Chief technology officer (pág. 49) Assistant de marketing (pág. 53) Controller presupuestario (pág. 52) Business relations manager (pág. 49) Editing manager (pág. 49) Consultancy services

\footnotetext{
${ }^{70} \mathrm{El}$ uso de este término se repite en tres ocasiones en los anuncios de nuestro corpus escritos en español. No podemos olvidar que muchos anuncios que provienen de un país lingüísticamente diferente han sufrido una covert translation (House, 1981; cf. Gutt, 1991,3): traducción que es percibida por los receptores como texto original y no como traducción. El uso de anglicismos tan infrecuentes en el lenguaje cotidiano como reportar con el significado de "informar" o implementar con el significado de "llevar a cabo" es un claro síntoma de este fenómeno.

${ }^{71}$ En este mismo anuncio encontramos cuatro ofertas de empleo, tres de las cuales recurren al uso de anglicismos: Controller, Marketing Manager y Assistant de Marketing.
} 
Figura 1

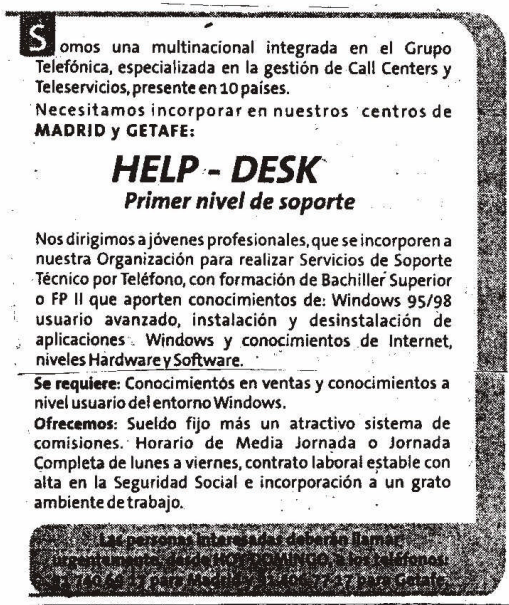

Figura 4

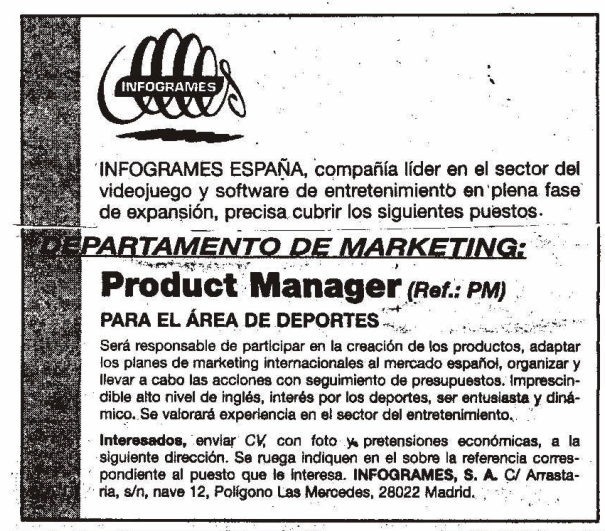

Figura 2

Grupo de Empresas, sector Gran Consumo, sólidamente
establẹcido precisa para continuar su desarrollo
Reportando a Dirección de Marketing será responsable del
diseño y puesta en práctica de las estrategias de marketing
relativas a sus productos, realización de acciones promocionales,
gestión de sus presupuestos...
Buscamos: Jóvenes profesionales, con 3-5 ańos de experiencla
en funciones similares, preferiblemente con medios de
comunicación o productos de gran consumo. Titulación
Universitaria. Idioma inglés fluido. Usuarios de ofimática e
internet. Iniciativa, dinamismo, sentido práctico, excelente
facilidad de negociación y comunicación. Residentes en Madrid.
se ofrece: Incorporación a grupo en fuerte expansión.
Remuneración competitiva a negociar de acuerdo a la valía y
experiencia aportadas.

Figura 3

\footnotetext{
Nuestro Cliente es la filial española de una de las principales Compañias Eléctricas alemanas, que pone en marcha un importante proyecto de desarrollo de negocio en nuestro pais. Por ello, precisa incorporar en su sede de Madrid, profesionales que respondan á los siguientes perfiles:

\section{Controller}

\section{Funciones:}

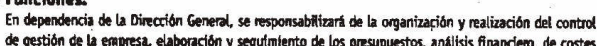

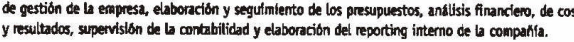

Buscamos:

- Tituludo/a en Ciencias Economicas, Empresariales, ICADE o equlvalente, con formación de

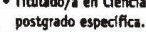

- Atto nivel de Ingless, valerándose los conocimientos de Alemán, Usuario avanzado de

informatica.

- Sollda axperiencia profestional en functones similares a las descritas adquirída en empresas de caricter multinacional de los sectores Electrico, Energetico, Telecomunicaciones, Gran

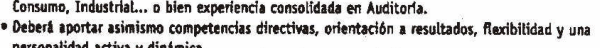

\section{Administrativo Comercial}

\section{Funciones:}

Integrado en el Departamento Comenctal, sie vesponsabilizars do prestar apoyo administrativo a La acción del equipo de ventas de la compañitient toda lo relacionado con la elaboración de ofertas, redacción de contratos y atención telefénica a clientes.

Buscamos:

- Diplomado/a en Ciencias Enprosariales o Técnico Espectalista Administrativo o equivalente. - Nivel alto de Ingles y/o Alemain, y habbito de trabajo con Microsoft officic.

- Experienta en funciones stmilares a las descrites adquirida en un Departamento Comercial de

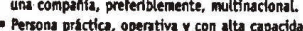

\section{Marketing Manager}

Funclones: andispis de clientes, consumos y evodución, desarrollo de modelos de pricing y toma de decásiones, elabboracion de estudios estadísticos de mercado y previsiones, y creacín del sistema de reporting propio.

Buscamos:

- Titulado/a universitaria en Ciencias Económicas, Empresariales, ICADE o Ingennierfa, con formación de postgrado en Marketing y elevados conocimientos de metrodos cuantituativos.

- Alto nlver de Ingless, valord́ndose los conocimientos de Alemantr. Usuario avanzado de informatica. - Solida experiencia profestional en funciones similares a las describs adquirida, preferiblemente, en una compania de los sectores tectrico, Energetice, Telecomunicationes, Gran Consumo, Industrial.... o blen experiencia consolidada en

- Dejera aportar asimismo capacidad para trabajar con autonomfa y responsabilidad, elevada copsoidad de ansilisis y

\section{Assistant de Marketing}

\section{Funciones:}

En dependencia del Marketing Manager, se occupard de apoyar la restizacín de las functones propias del Depertamento en todo lo relacionado, principalmente, con la recorida y tabulación. de datos, soporte infiom f́tico y aporo orgenizattro Buscamos:

- Diplomado/a en Ciencias Empresariales, Marketing o equivalente.

- Niplomadolata en Ciencias Empresariales, Marketting o equivalente.

- Experiencia en funciones simílares. a las descritas, adquirida en un Departananto de Marketing de una comparifia o bien en una empress de Investigación de Mercados.

- Persona practica, operativa y con alta capacidad de trabajo en equipo.

Ofrecemos para todos los puestos:

Incosporación a una Companfia en pleno proceso de expansión y crecimlento en la que encontrarán, a todos los siveles, amplias posibilidades de desarrollo profesionall ta retribudón se negociard individualmente, no descarténdose ninguna candidatura por nazones económicas.

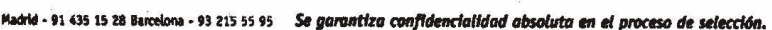


manager (pág. 49) Assistant departamento técnico (pág. 49) Software engineers (pág. 43) E-business marketing manager (pág. 42) Consultores E-business (pág. 41), etc. La posible opacidad del término inglés que introduce la demanda de empleo se compensa con la descripción del puesto de trabajo que se lleva a cabo en el perfil. El hecho de que los anuncios utilicen con mucha frecuencia el inglés para presentar la información resaltada tipográficamente y la existencia de términos españoles equivalentes y de uso común (manager - director, assistant - ayudante) nos hace pensar que, en estos casos, el uso de anglicismos no responde al afán de mantener una estricta fidelidad con el término original sino que obedece a un deseo de favorecer la implicación del receptor en el acto comunicativo mediante el uso de un estímulo lingüístico que el destinatario percibe como atractivo.

No es la demanda la única parte de la superestructura en la que abundan los anglicismos. También son muy frecuentes en la presentación de las empresas solicitantes de empleo como muestran los siguientes ejemplos, seleccionados de diferentes anuncios de nuestro corpus:

Staff consultants requiere ... (pág. 46)

Powerline s.l. marketing telefónico (...) desea incorporar ... (pág. 46)

Air Digital telecomunicaciones seleccionamos ... (pág. 41)

Aser Family s. 1. contrata ... (pág. 38)

Look and find busca comerciales ... (pág. 39)

Enviar curriculum a Card Explosion (pág. 41)

Interesados enviar CV con fotografía reciente a Integral Office Comunicaciones S.L. (pág. 43)

Te esperamos en nuestras oficinas Cibertelplus (pág. 45)

La adopción de un nombre de filiación angloamericana por empresas que, en su mayoría, son netamente españolas y trabajan exclusivamente en España se explica por el deseo de buscar una asociación con las cualidades positivas que dentro del mercado laboral se presuponen a las multinacionales - principalmente norteamericanas - sin 
manifestarlo explícitamente ${ }^{72}$. Las compañías españolas tampoco dudan en presentar sus organigramas, secciones, departamentos, equipos, etc. recurriendo al uso de anglicismos crudos:

Compañía española de búsqueda de ejecutivos y directivos quiere incorporar en su equipo de SEARCH EXECUTIVE una persona con excelentes recursos profesionales para responsabilizarse de la dirección de clientes y proyectos. (pág. 58)

Muchas empresas, mayormente multinacionales, concluyen los anuncios que utilizan para presentar sus ofertas de empleo redactadas en español con una especie de rúbrica escrita en lengua inglesa. Esta rúbrica, intencionalmente resaltada tipográficamente, puede bien explicar las funciones de la empresa o bien introducir un eslogan de carácter identificativo:

Human: Human Management Systems (pág. 58)

Hp - invent (pág. 57)

Emirates - Be good to yourself. Fly Emirates. (pág. 54)

Kenan- Lucen Technologies. Bell labs innovations. (pág. 54)

Eumetsat - Europe's Meteorological Satellite Organisation. (pág. 52)

Atkearney - an EDS company (pág. 51)

Telenium - The new millenium Telecom Company. (pág. 43)

Pricewaterhousecoopers - Executive search and selection. (pág. 41)

Echo - Mobile phone Accessories (pág. 41)

Bran Luebbe - A United Dominion Company (pág. 45)

Como veremos más detenidamente en el análisis de la publicidad comercial, que llevaremos a cabo en el tercer apartado de nuestro trabajo, la rúbrica es, por su disposición en la página, la última parte del anuncio que el destinatario percibe. El hecho de que se opte por redactarla en inglés puede responder a un deseo de que el lector finalice su lectura teniendo muy presente la vocación internacional de la empresa.

\footnotetext{
${ }^{72}$ Este fenómeno entra dentro de lo que Tanaka (1994) denomina covert communication y, como veremos en el apartado 2.7.2. , tiene una serie de consecuencias muy ventajosas para el emisor del mensaje.
} 
Además, la rúbrica actúa como una especie de sello identificador de la compañía ya que suele aparecer en todas las comunicaciones de la empresa, incluyendo los anuncios aparecidos en diferentes países.

\subsubsection{2. - Ofertas de empleo íntegramente escritas en lengua inglesa}

En el Simposio Internacional "Lingüística y Sociedad" celebrado en 1995 en la Universidad de Salamanca la profesora Elorza reflexionaba en torno al uso que se hace de la lengua inglesa en los anuncios de ofertas de trabajo publicados en España. Su estudio tomaba como base el análisis de más de quinientos anuncios publicitarios aparecidos en la sección "Ofertas de Empleo" del suplemento "Negocios" de "El País", año X, nums. 465 (25/IX/1994), 468 (16/X/1994), 469 (23/X/1994), 474 (27/XI/1994) y 476 (11/XII/1994). Las conclusiones de su análisis estadístico son las siguientes: de los 522 anuncios consultados, 14 están totalmente redactados en una lengua extranjera (10 en inglés, 3 en Francés y 1 en alemán); otros 8 emplean el español únicamente como lengua secundaria para dar información poco o nada prominente; 16 presentan la información resaltada en inglés, además de otros 26 que contienen en inglés sólo parte de la información resaltada; y por último, aparecen 2 anuncios en los que se presenta el nombre del puesto de trabajo en español con su correlativo inglés entre paréntesis. Todos estos anuncios constituían el $12^{\prime} 7$ por ciento del total.

Si llevamos a cabo un análisis de la presencia de la lengua inglesa en las ofertas de empleo que hoy en día aparecen en el suplemento "Negocios" de ese mismo diario (año XIII, num. 751 (26/12/2000) podemos comprobar cómo el fenómeno se ha incrementado en los últimos seis años. De los 132 anuncios publicados, 16 están completamente redactados en una lengua extranjera (15 aparecen en lengua inglesa ${ }^{73}$ y uno se redacta en francés); 3 presentan toda la información tipográficamente resaltada en inglés y 14 contienen en inglés sólo parte de la información resaltada; en uno de ellos se presenta el nombre del puesto de trabajo en español con su correlativo inglés. Los anuncios con una destacada presencia de la lengua inglesa constituyen el 25 por ciento del total.

\footnotetext{
${ }^{73}$ Uno de estos anuncios aparece repetido (figura 7) bien por un error atribuible al diario o bien por un deseo de la empresa de no perderse lectores despistados. Dos de las seis ofertas de trabajo publicadas a página completa estan íntegramente redactadas en lengua inglesa (figuras 12 y 16).
} 
Después de haber cuantificado la magnitud del fenómeno, nos corresponde buscar las causas que puedan explicar el uso intencional de un estímulo lingüístico distinto al esperado por el receptor: en este apartado no estudiaremos las ofertas de empleo que combinan lengua inglesa y lengua española, ya analizadas anteriormente, sino que nos centraremos en los anuncios íntegramente redactados en inglés.

Una primera aproximación a una oferta de empleo escrita en inglés puede llevarnos a pensar que el anuncio se dirige a personas residentes en España pero nacidas en un país anglófono. Sin embargo, el análisis de nuestro corpus invalida esta hipótesis como explicación general a este fenómeno: de los quince anuncios redactados en inglés sólo en uno de ellos se exige al aspirante ser "native speaker of English". Se trata de una institución británica, el British Council, que selecciona profesores de inglés como lengua extranjera (figura 5).

Una vez descartada esta primera presunción pasamos a formular una segunda hipótesis: la empresa decide publicar el anuncio en lengua inglesa debido a que el trabajo que se ofrece se desempeñará en un país anglófono ${ }^{74}$. Esta circunstancia ocurre en dos de los quince anuncios que componen nuestro corpus. En uno de ellos (figura 6) se solicitan enfermeros/as para trabajar en el Reino Unido y no se pide explícitamente un determinado conocimiento de la lengua inglesa. Sin embargo, la publicación del anuncio en inglés parece presuponer la necesidad de que el candidato al puesto de trabajo domine este idioma. La intencional redacción del anuncio en lengua inglesa actúa entonces como un requisito implícito dentro del campo de la comunicación inferencial ${ }^{75}$. El anuncio de la compañía norteamericana $C N B C$ (figura 7) responde a las mismas características: se publica en inglés sin hacer referencia explícita a las destrezas lingüísticas del candidato aunque tanto la naturaleza del trabajo como el hecho de que éste se vaya a desempeñar en Londres ayuda a presuponer que un cierto dominio del inglés es un requisito imprescindible para los candidatos.

\footnotetext{
${ }^{74}$ En esta ocasión, la lengua inglesa puede funcionar como antirestrictor (Elorza 1995: 3) ya que posibilita el acceso a la información del texto tanto a los hablantes nativos de inglés como a las personas que tengan el inglés como segunda lengua.

${ }^{75}$ En los siguientes apartados prestaremos atención a las particularidades de la comunicación inferencial, clave para comprender el fenómeno de la utilización de la lengua inglesa en numerosos anuncios publicados en España.
} 


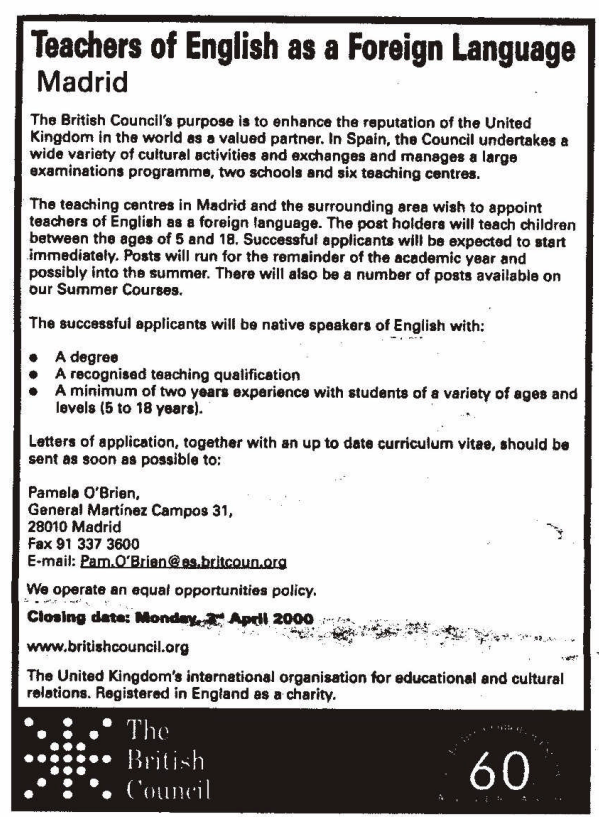

Figura 5

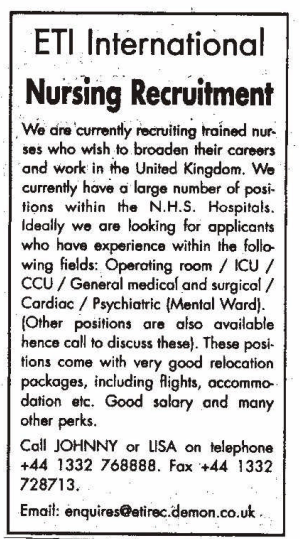

Figura 6

\section{살.}

TOP TALENT NEEDED FOR THE WORLD's LEADING BUSINESS NETWORK Backed by GE and Dow Jones, CNBC, the global television nerwork secn in
170 million horres atound the world, is growing rapidly and has immediate opportunities in Europe for:

Frankfurt Reporter Market Reporter E-Business Reporter Producers Assistant Producers

For further details please see www.cnbceurope.com If you are experienced with 2 strong knowledge of business in Europe, we want you to Ail vacancies other than the Frankfurt position will be based in London. Please send your $C V$ and showrel to:

Human Resources Dept., CNBCC Eurper, 10 Flect Plase. L.ondon, ECSM 7QS: UK

Figura 7

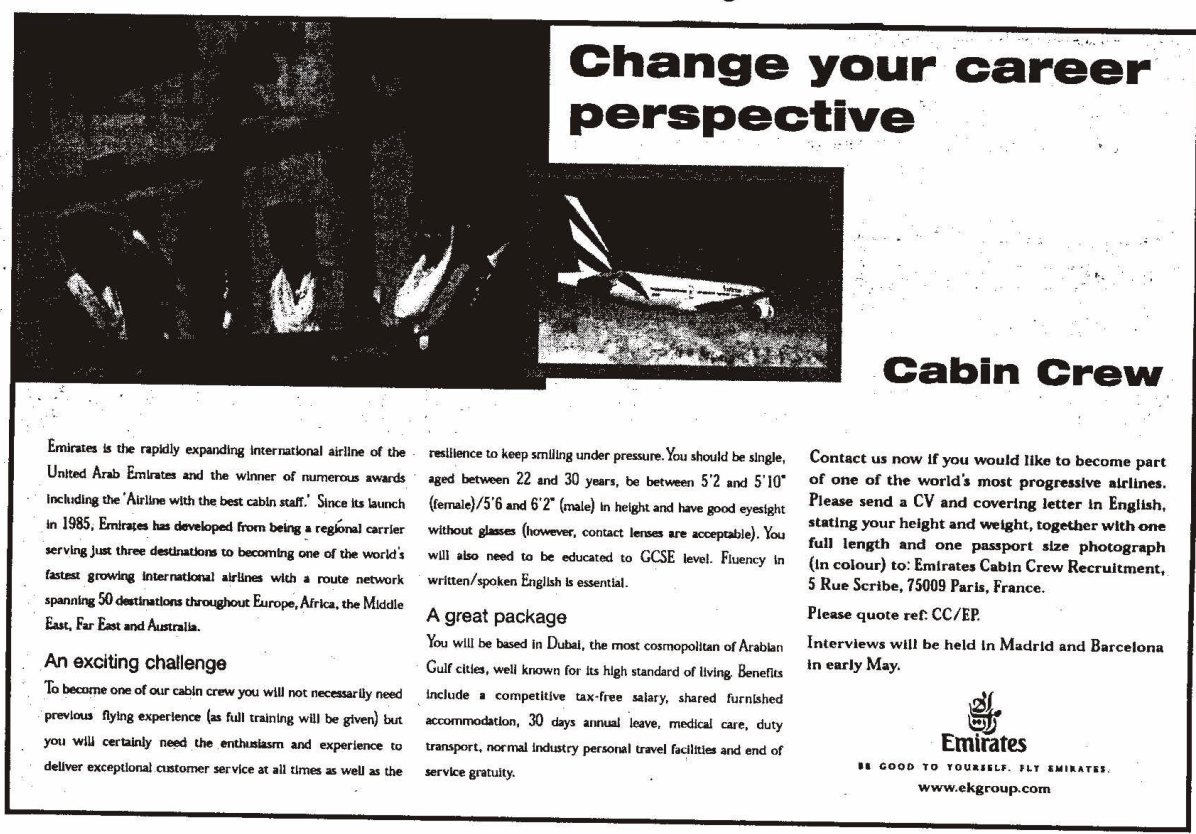

Figura 8 
La compañía aérea Emirates (figura 8) también se dirige a los lectores de ofertas de empleo publicadas en los diarios españoles con un anuncio en lengua inglesa que comunica una próxima selección de personal de cabina de pasajeros. Se informa de que el trabajo se desempeñará en Dubai y las entrevistas se llevarán a cabo en Madrid y Barcelona durante el mes de Mayo. Además se pide al aspirante que redacte su Curriculum Vitae y una carta de presentación en inglés ${ }^{76}$ y se toma como referencia del nivel de estudios solicitado una titulación británica: "You will also need to be educated to GCSE level". En esta ocasión se solicita explícitamente un nivel lingüístico de inglés que no está restringido a los hablantes nativos: el "fluency in written/spoken English" de este anuncio contrasta con conceptos más restrictivos como "English as mother-tongue" o "native speakers required".

Un caso similar ocurre en la oferta de empleo del anuncio reproducido en la figura nueve. Eumetsat (Europe's Meteorological Satellite Organization) utiliza la lengua inglesa para cubrir un puesto de trabajo en la ciudad alemana de Darmstadt. Uno de los requisitos que se pide a los aspirantes es ser miembro de alguno de los diecisiete países europeos que se citan en el anuncio. El hecho de que la gran mayoría de los países que se nombran pertenezcan a la Unión Europea puede explicar que se exija fluidez en inglés o francés - así como presentar la solicitud en uno de estos idiomas - ya que ambas lenguas gozan de una destacada consideración dentro del marco de la Unión Europea. Aunque el trabajo se desarrollará en Alemania, en ningún momento se hace mención a la necesidad de conocer el idioma alemán.

Sin embargo, la inmensa mayoría de los anuncios publicados en lengua inglesa en diarios españoles ofrecen puestos de trabajo que se desempeñarán en España (véanse los ejemplos que van desde la figura 10 a la 19), lo que nos lleva a formular una tercera y definitiva hipótesis: se trata de ofertas de empleo en empresas multinacionales en expansión que precisan profesionales que puedan comunicarse en lengua inglesa obedeciendo a las particulares necesidades de cada empresa. Veamos algunos ejemplos.

\footnotetext{
${ }^{76}$ En esta ocasión la empresa pide explícitamente al hablante que responda a su oferta de empleo utilizando la lengua inglesa. Si seguimos los postulados del Principio de Cooperación - Grice (1975), de Beaugrande y Dressler (1981) - la mera publicación del anuncio recurriendo al uso de la lengua inglesa debería interpretarse como una petición implícita para que se responda al anuncio utilizando el mis mo idioma (véase Elorza 1995: 2).
} 


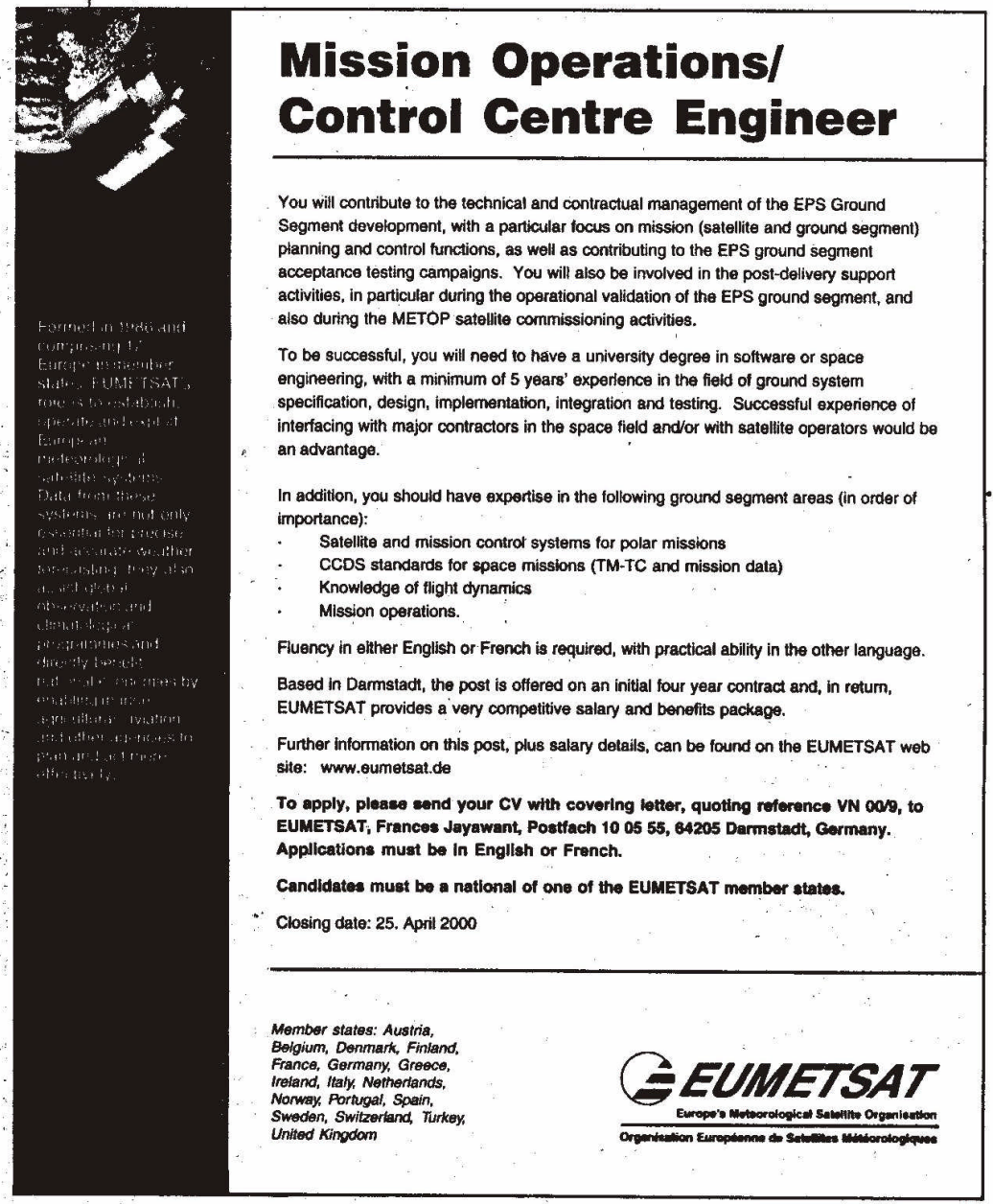

Figura 9

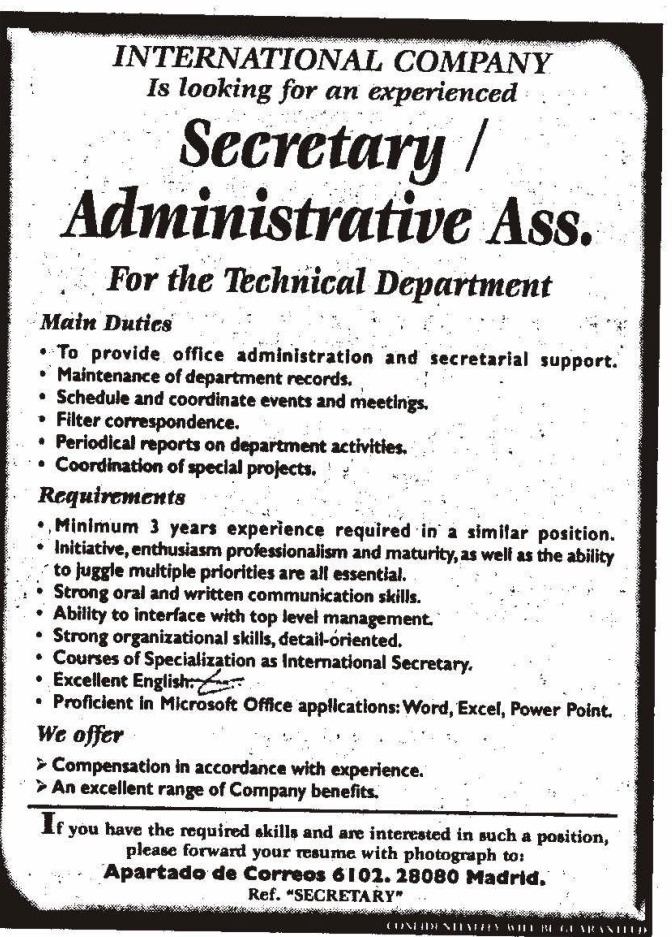

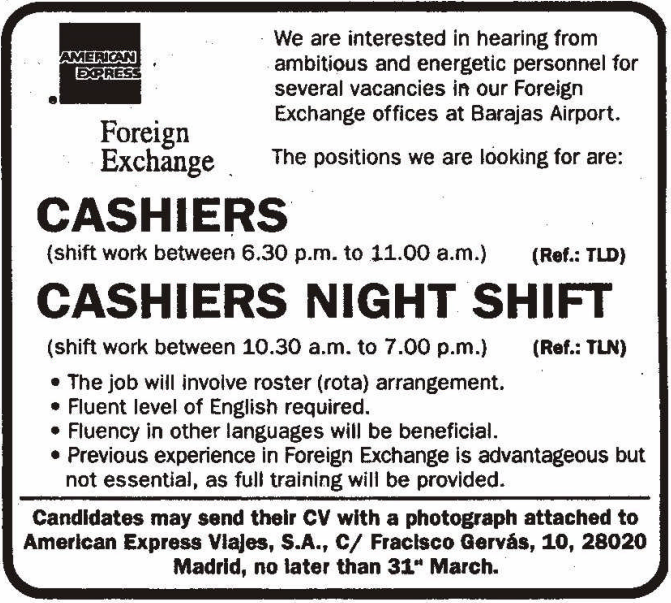

Figura 11

Figura 10 
En el anuncio reproducido en la figura 10, una compañía internacional busca secretario y auxiliar administrativo con experiencia y "excellent level of English" para sus oficinas en Madrid. En el anuncio de la figura 11 comprobamos que American Express necesita personas que posean "fluent level of English" para trabajar en sus oficinas de cambio de divisas en Barajas. La consultora multinacional Atkearney (figura 12) solicita personal para su filial española en Madrid sin hacer mención explicita a que los aspirantes tengan una cierta competencia en la lengua inglesa pero sí haciéndolo de manera implícita mediante la redacción del anuncio en inglés. Kenan, multinacional proveedora de software empresarial, publica dos anuncios (figuras 13 y 14) para cubrir diversas vacantes, principalmente localizadas en Madrid pero también en otras ciudades europeas. El texto del anuncio concluye con la siguiente advertencia: "Please note that as well as English you must be fluent in the native language of your preferred location".

Saillabs (figura 15) solicita ingenieros de software para sus oficinas de Barcelona con experiencia en el campo de la traducción asistida por ordenador y con "a good command of the English language". Hewlett Packard (figura 16) también busca ingenieros de distintas especialidades - software, electrónica, mecánica, etc. - para sus oficinas en Barcelona con un nivel de inglés que en unos casos es imprescindible para poder optar al puesto de trabajo, "Fluent English is essential", y en otros casos se presenta como muy recomendable: "Fluency in English is strongly desired".

Admirall Prodesfarma, (figura 17) multinacional farmacéutica española, necesita un director de asuntos internacionales. Aunque no se hace mención explícita a la necesidad de poder comunicarse en lengua inglesa se advierte que el trabajador elegido formará parte de un equipo de proyectos internacionales. La filial francesa de la Compagnie Deutsch (figura 18) tampoco hace mención explícita a la necesidad de un dominio de la lengua inglesa para los aspirantes a trabajar en sus oficinas en España, aunque como todos los anuncios que estamos examinando en este apartado publica su anuncio íntegramente en lengua inglesa.

Además de haber optado por redactar su texto en inglés, podemos comprobar cómo muchos de estos anuncios exigen explícitamente un determinado dominio del idioma (figuras 5, 8, 9, 10,11, 13, 14, 15 y 16). Otras empresas consideran que mediante 


\section{International Support For Tomorrow's Communications Solutions}

Kenan Systems Corporation is a leading provider arder management, pedition for biling, customer care single and multi-service communications and energy companies worldwide. Our products meet the needs service providers in the com munications marketplace, including fixed and mobile services, broadband and Unternet as well as in the energy industry.

Ance of developente industry needs and matching Corporation a workd leader aede Kenan Systems

With over 3,200 staff

an ethos of agility, dynamism, wifide the company has cam focus and a commitmens to first-class cursomer service - balanced with the security and confidence the comes with being part of Lacent Technologies. We have european olfices in London, Madrid, Munich, Paris We now have exciting and chellive list of castomern. in the following areas

\section{Customer Support Consultants}

Madrid, Munich, Paris, London, Milan

In this varied and challenging role you will be responsible for the installation and delivery of technical support and consultancy

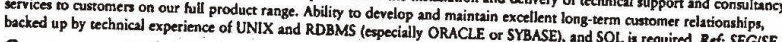
Systems Administrator/Desktop Support

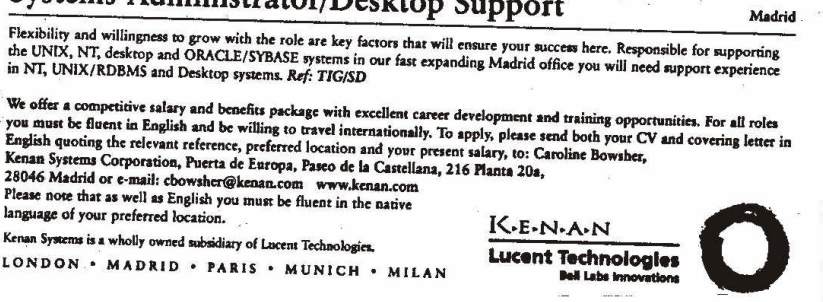

Figura 13

\section{International Consultancy For Tomorrow's Communication Solutions}

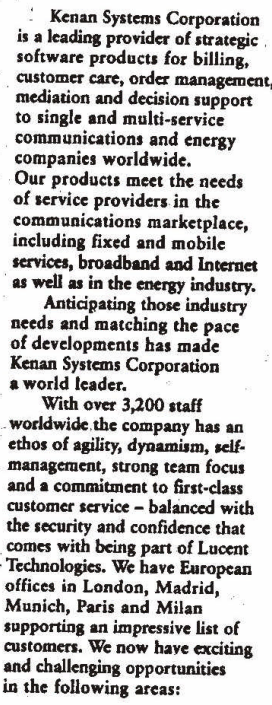

\section{Developers}

As part of the Consulting team you will be responsible for the analysis, design and coding of developments and enhancements for projects. You should have experience of the full software development life cycle, together with C, UNIX and preferably $\mathrm{C}++$, ORACLE or SYBASE, Ref: SDG/D

\section{Project Consultants Madrid, Londo}

Working in small project teams the role involves close inceraction with clients at all levels to translate their business requirements and deliver software solutions to underen (preferably ORACLE or SYBASE) Ref: COCS and RDBMS or SYBASE), Ref: CG/PC

We offer a competitive salary and benefics package with

$$
\begin{aligned}
& \text { Software Trainers } \\
& \text { To plan, manage and deliver external and internal } \\
& \text { technical training courses across our full product range, } \\
& \text { you must demonstrate a proven track record in trechnical } \\
& \pi \text { training and ideally a knowledge of SQLL, RDBMS } \\
& \text { and UNIX. Ref: ESG }
\end{aligned}
$$
Madrid

As parc of our Sales and Markecing group you will work closely with prospective customers to understand their business and technical requirements and then present software solutions to meet their needs. You must have exceptional communication and influencing skills consultancy and/or Pre Sales experience and knowledge of UNIX, NT, RDBMS applications, Ref: SM/PS

We letter in English quoting the relevant reference, preferred iocationally. To apply, please send both your $\mathrm{CV}$ and covering Caroline Bowsh quoting the relevant reference, preferred location and your present salary, to:

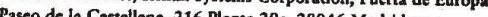
Dreo de Castelna, 216 Manca 202,28046 Madrid or Plase corchar

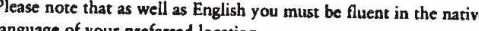

Kenan Systems is a wholly owned subsidiary of Lucent Technologies LONDON - MADRID - PARIS • MUNICH - MILAN

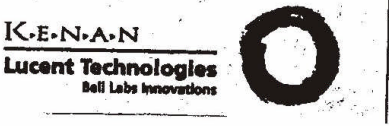

Figura 14

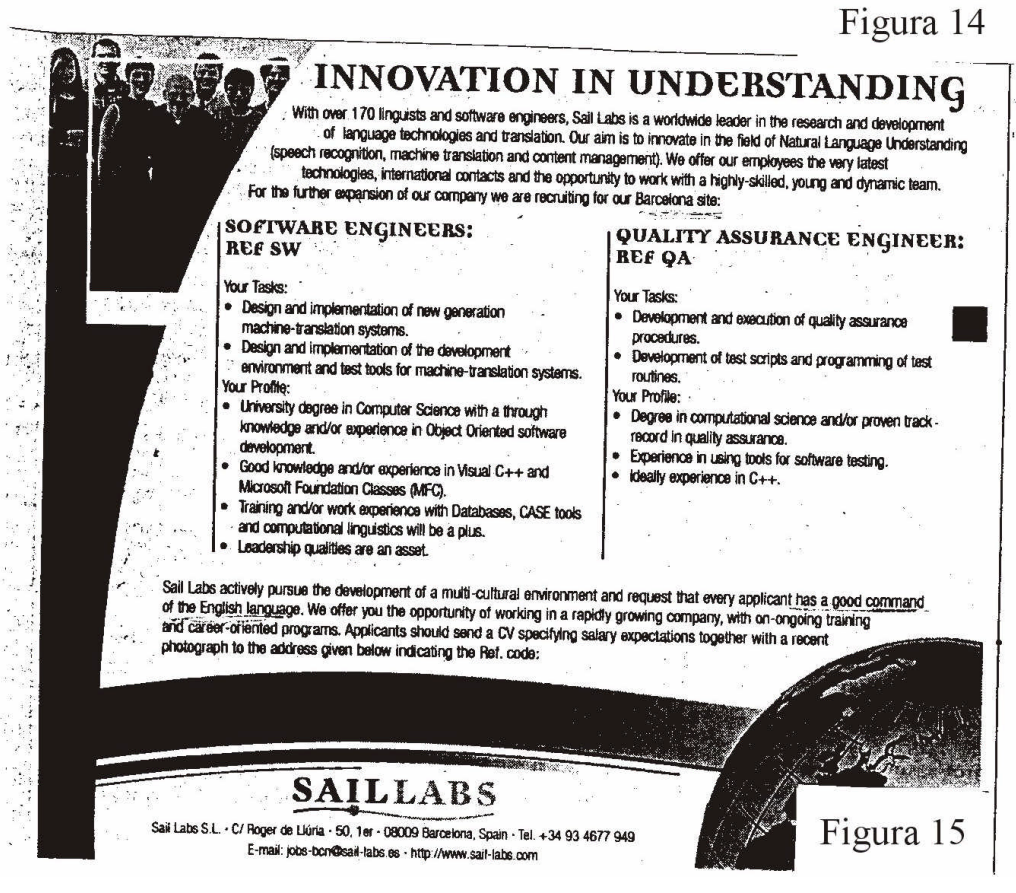




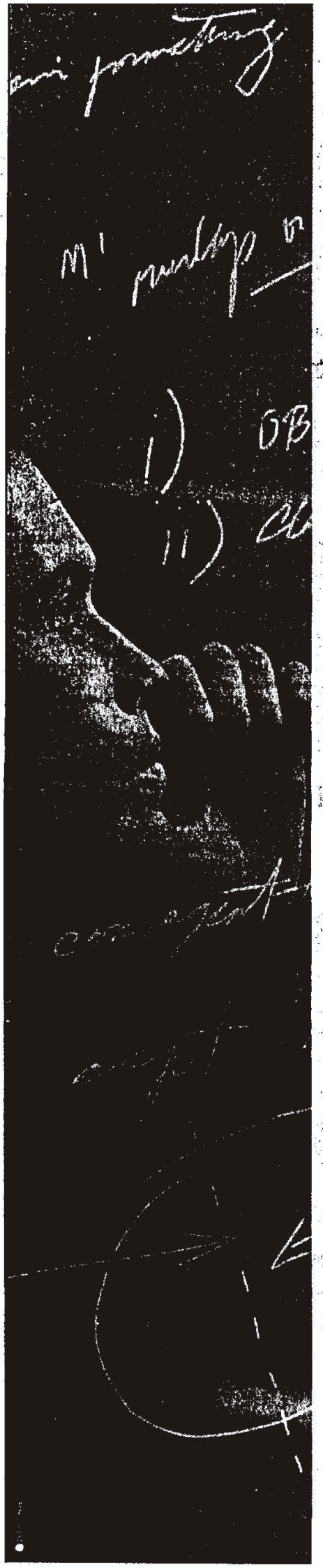

\section{What about your ideas?}

\section{Ideas mean the world to us at hp. A diversity of ideas means even more.}

At hp, your ideas can go anywhere. Whether irs by defining the marketing, R\&D and manufacturing strategy for large format printers or being responsible for manufacturing inkjet products in Europe, our people are defining the next steps in the imaging and the infernet world.

The following opportunity is currently available:

R\&D Mechanical Engineers Ret. 2585-EP|

We are looking tor senior ond junior Mechanical Engineers. As a member of the R\&D staff you will be responsible for defining, designing and developing mechanical subbsystems and/or servo-systems for our new lorge format printers. You will be involved in all stages of development from initial conceppsts through production: definition based on user needs, construction and testing of prototypes, design and verification of mechonical subsystems.

You will work in an inferdisciplinary leam interacting with oither HP divisions worldwide. A university degree in Mechanical Engineering and fluent English are essential. Experience in design and anolysis of mechanicol components will be valued, particularly in technical plastics, sheet metal, extrusion, turned parts, as well as good knowledge of the following areas: statics of materials, dynamics, vibrations, fluid dynamics, control, and heat transfer systems.

\section{Electronic Design Engineers ket. 2586-ep}

As a member of the R\&D staff you will work on efectronic design for new large formot printer development projects. We are looking to fill several positions in both the onolog and digital design areas: We will value your experience or fraining in any of the following areas: microprocessor-based systems cnd digital design, analog circuit design, power supplies, control eirevits, motors and sensors, electromognetic compatibility, Electronic Design Automotion (EDA) Tools at user level.

You should olso hove a university degree in Tolecommunications, Electronics or Electrical Engineering, and be fluent in English.

\section{Software Design Engineers. (Ref. 2587-kP]}

As a member of the R\&D stoff working on development projects for new large format printers you will be responsible for one of the following soltware design areas: softwore development in Windows and/or Macinlosh environments, firmware development for embedded systems with real time operating systems, digital processing of images, colour or graphics.

You need a university degree in Computing or Engineering, knowledge of structured and/or object oriented programming and $\mathrm{C} / \mathrm{C}_{++}$. Fluency in English is strongly desired. We have several open positions, all involved with the areas described above. Experience in any of these areas will be valued.

\section{Electrical Product Engineer [Ret. 2388-Ep|}

As a member of the Monufacturing staff, you will be responsible for the development and execution of projects, focusing on cost reduction, quality assurance and troubleshooting of product problems in manufacturing. You will be in charge of electrical and electronic subsystems, based on: Microprocessors, power supply, control circuits, motors and sensors, working with vendors sited around the world. Furthermore you will develop ond design the strategy for test activities of the products: Soffware tests and process control (relation with firmware, acquisition of data, etc.). Hardware tests (systems of measurement. electronic test instrumentss. In the development and specification process you will work in collaboration with R\&D staff.

A university degree in Telecomunications, Electronics or Electricol Engineering and lluency in English are essential Experience in hordwe e design and instrumentation, your analytical skills and creativity for engineering problems as well as knowledge of programming in C and UNIX will be volued.

The opportunities ore in Barcelona.

The selection process will be conducted by BP Consejeros Empresariales, S.A. (Barcelona)

" It's time to talk to us. To apply please...

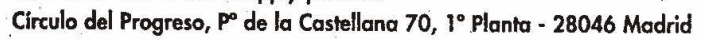

We will prioritize your application through:

\section{jobs.hp.com}

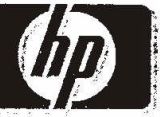

i n $v e n$ 


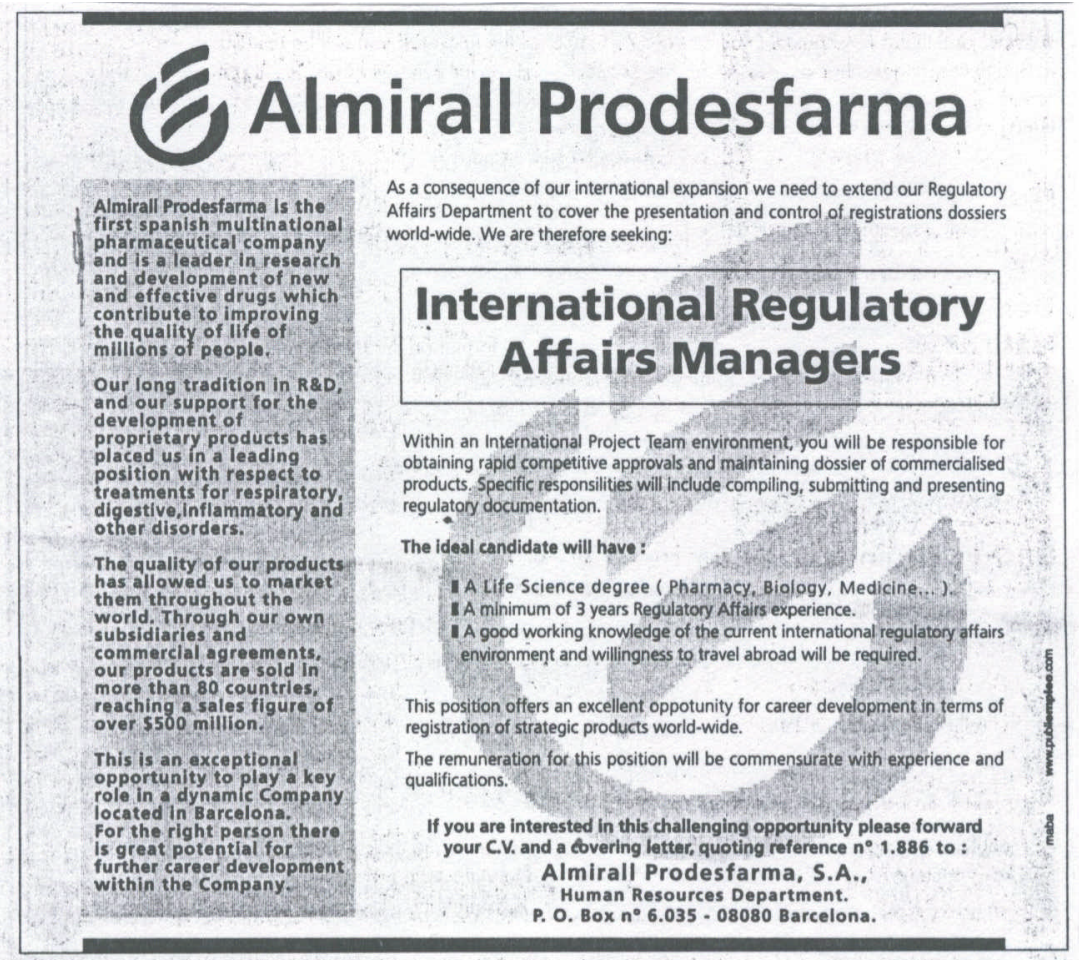

Figura 17

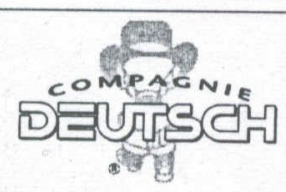

\section{FIELD SALES ENGINEER}

INTERCONNECTION PRODUCTS FOR THE AEROSPACE \& RAILWAY INDUSTRIES

$$
\text { COMPETITIVE SALARY, BONUS, FULLY EXPENSED CAR }
$$

DEUTSCH is a long established and respected connector house with a world-wide market. Compagnie Deutsch of France are seeking to recruit a highly motivated technical sales professional with a working knowledge of the aerospace and railway industries to create new business opportunities and design ins for a range of proven high reliability harsh environment interconnection products.

Based in Spain, the role will involve travel within Spain \& France.

If you are interested, please send your CV to:

Direction of Human Resources - Compagnie Deutsch - 10, Rue Lionel Terray - BP 207 92502 Rueil Malmaison Cedex - France.

Internet:http://www.compagnie-deutsch.com 
la publicación del texto en inglés ya se ha comunicado implícitamente este requisito (figuras 6, 7, 12, 17, 18 ).

La necesidad de hablar inglés está directamente relacionada con el cometido del trabajo a realizar: muchas empresas advierten en el cuerpo del texto que el candidato deberá tener disponibilidad para viajar a diferentes países (figuras 13, 14, 17 y 18) o que deberá integrarse en un equipo de trabajo multicultural en el que la lengua inglesa actuará como medio de comunicación (figura 15). La mayoría de las empresas resaltan como uno de sus mayores atractivos, su carácter multinacional (figuras 9, 10, 12, 13, 14, 15, 16 y 17).

Después del anterior análisis podemos concluir que el uso de la lengua inglesa en las ofertas de trabajo publicadas en España obedece a diversas finalidades: solicitar hablantes nativos de inglés, demandar personal dispuesto a trabajar en el extranjero o buscar empleados que se puedan comunicar en lengua inglesa. Centrándonos en este último caso, el más frecuente en el mercado laboral español, podemos comprobar que, desde un punto de vista estrictamente comunicativo, los anuncios íntegramente escritos en lengua inglesa actúan como un reclamo para el lector con competencia en este idioma: "Debido a las condiciones contextuales del texto, rodeado de otros textos en español, el empleo de la lengua inglesa se interpreta como una llamada de atención al lector" (Elorza 1995: 3). Este tipo de anuncios funcionan, a su vez, como un elemento restrictor para los lectores que no posean las destrezas lingüísticas requeridas para comprender el anuncio:

La perspectiva que se adopta es la del lector real con deficiente competencia lingüística en inglés, por lo que publicar el anuncio en esta lengua se interpreta como un afán de preseleccionar al aspirante ya desde su condición de lector potencial. Se le desanima para que, no siendo el candidato adecuado, abandone la idea de optar al puesto antes de que llegue realmente a profundizar en la información del texto. (Elorza 1995: 2)

Tampoco debemos olvidar que, al igual que ocurría con el uso de anglicismos crudos, el prestigio inherente a la lengua inglesa en el ámbito comercial dota al texto de un mayor atractivo para el destinatario: 
Aunque el anunciante no decida deliberadamente publicar el texto en inglés porque lo considere más prestigioso, hay indicios en el sondeo de opinión de que la consideración de al menos algunos hablantes hacia el inglés es positiva. Esto significa que, siquiera potencialmente, se puede utilizar como sociolecto elitista en España. Este aspecto, que podría llegar a generalizarse (si no lo está ya) y ser asimilado por la cultura idiosincrática española, deberá ser tomado en cuenta a la hora de valorar el impacto que la presencia de la lengua inglesa en un tipo de discurso cotidiano como el analizado pueda tener en la sociedad española y en su lengua. (Elorza 1995: 6)

Las ofertas de empleo que estamos analizando se dirigen a un lector potencial restringido: estudiantes y trabajadores, normalmente españoles, que puedan comunicarse mediante la lengua inglesa aunque tampoco descartan a los hablantes nativos de inglés residentes en España que posean el perfil exigido.

El dominio de la lengua inglesa no es un requisito imprescindible para todos los trabajos que el mercado laboral español ofrece. En general no se presenta como necesaria en los puestos de una menor cualificación profesional (electricistas, encuadernadores, montadores de pladur, fontaneros, técnicos en instalación de calefacciones, etc.) y tampoco en trabajos que requieren una cualificación profesional alta pero que se desarrollan en un ámbito local o regional (médicos, ingenieros de caminos, topógrafos, arquitectos, etc.) Alvarez y Cruz (1994) defienden que el dominio de una lengua extranjera sólo es un requisito fundamental para los white collars españoles: trabajadores del sector administrativo-financiero con titulación superior o media. Por la propia naturaleza internacional del mercado tecnológico actual debemos añadir a este grupo a los trabajadores directamente relacionados con las grandes empresas multinacionales: ingenieros de telecomunicaciones e informáticos principalmente. 


\subsection{3. - El inglés en la publicidad comercial}

\subsubsection{1. - Objetivo de nuestro análisis}

El corpus que nos disponemos a analizar se compone de anuncios publicados a una o doble página en los dominicales que acompañan a la prensa española ${ }^{77}$. Nuestro objetivo consiste en poner de manifiesto la frecuencia con la que distintos productos publicitarios recurren a la lengua inglesa para comunicarse con un destinatario que bien no la utiliza como código habitual o bien la desconoce por completo. En esta ocasión no estamos examinando la frecuencia de uso de anglicismos, más o menos integrados en el sistema lingüístico español, sino que estamos haciendo referencia bien a la existencia de ciertos términos o enunciados en inglés que se insertan en un anuncio redactado en español o bien a la presencia de anuncios íntegramente escritos en lengua inglesa. Para cuantificar este fenómeno, hemos seleccionado todos los anuncios publicados durante el mes de marzo de 2000 por cinco de las revistas dominicales de mayor difusión en España: El País Semanal, Blanco y Negro, el Magazine, el Semanal y el Dominical ${ }^{78}$.

En el apartado 1.5.3. ya hemos visto que no todos los campos léxicos son igualmente proclives al influjo angloamericano. Este hecho también tiene su reflejo en el uso del inglés que hacen los anuncios de las diversas revistas que se publican en España: en la publicidad de las revistas de gastronomía, enología, caza o pesca este tipo de mensajes son muy poco frecuentes y, al contrario, son abundantes en la publicidad de las

\footnotetext{
${ }^{77}$ Hemos prescindido de los anuncios que formaban parte de la promoción de novelas, películas o enciclopedias por ser de una naturaleza distinta al resto de productos comerciales que componen nuestro corpus.

${ }^{78}$ El País Semanal se distribuye con el diario El País. Blanco y Negro se distribuye con el ABC, Huelva Información y Diario de Soria. El Magazine se distribuye con El Adelanto de Segovia, Diario XXI (Burgos), Diario de Ibiza, Diario de Mallorca, Faro de Vigo, Información (Alicante), La Nueva España (Asturias), La Opinión de Málaga, La Opinión de Murcia, La Opinión de Tenerife, La Opinión de Zamora, La Provincia-Diario de Las Palmas, Levante-EMV (Valencia) y La Vanguardia. El Semanal se distribuye con Diario 16, Diario de Avisos, Diario de Burgos, Diario de Cádiz, Diario de Jerez, Diario de León, Diario de Mallorca, Diario de Navarra, Diario de Sevilla, Diari de Tarragona, El Comercio, El Correo, El Diario Montañés, El Diario Vasco, El Norte de Castilla, Europa Sur, Heraldo de Aragón, Heraldo Soria 7 días, Hoy, Ideal, La Rioja, Las Provincias, La Verdad, La Voz de Galicia, Menorca, Sur. No disponemos de datos de los diarios que distribuyen El Dominical.
} 
revistas de consumo dirigidas mayoritariamente a los jóvenes: deportes ${ }^{79}$, música, moda, informática, etc. Los dominicales muestran un punto medio del fenómeno que estamos analizando por tener una temática de carácter variado y por dirigirse a un grupo de destinatarios bastante heterogéneo.

El resultado de nuestra selección es un corpus compuesto por 333 anuncios, de los cuales 141 no recurren a la lengua inglesa y 192 utilizan, en alguna parte de su estructura, la lengua inglesa. Hemos dividido nuestro estudio en ocho apartados que engloban aproximadamente el ochenta por ciento de los productos anunciados: anuncios de cosméticos, fragancias, relojes, moda, móviles e informática, automóviles, bebidas y tabaco. Cada apartado se compone de una breve introducción donde se pone de manifiesto alguna característica relevante del tipo de producto analizado, seguida por un gráfico de barras que muestra y cuantifica las partes del anuncio que recurren al uso de la lengua inglesa. Después de cada gráfico se reproduce la parte del anuncio que se redacta en inglés seguida de un número que aparece entre paréntesis y que especifica la frecuencia de aparición del anuncio en nuestro corpus. En tercer lugar introducimos un breve comentario a los datos que el gráfico de barras presenta para concluir con un gráfico circular que contrasta el porcentaje de anuncios que utilizan la lengua inglesa con los anuncios que no la utilizan.

\subsubsection{2. - Anuncios de cosméticos}

\section{Introducción}

Francia ha sido tradicionalmente considerada la cuna de los mejores productos de cosmética. Así, en los anuncios de nuestro corpus podemos comprobar que todavía existe una importante presencia de la lengua francesa aunque hoy en día ya se ve ampliamente superada por la lengua inglesa en las campañas de las marcas más publicitadas, que son tanto de origen norteamericano como de origen francés: Chanel, Biotherm, Clinique, Elisabeth Arden, Lancôme, Estée Lauder, etc.

\footnotetext{
${ }^{79}$ En la revista española Surf Planet todos los anuncios que aparecen en su número XXXI (publicado en Noviembre de 1999) recurren al uso de la lengua inglesa y más del ochenta por ciento de los textos de los anuncios se redactan exclusivamente en inglés.
} 
La industria de la cosmética presta una especial atención al diseño del envase del producto y en los anuncios de nuestro corpus éste siempre aparece en una posición preferente dentro de la ilustración. En numerosas ocasiones, el envase funciona como el principal elemento visual del anuncio.

\section{Anuncios de cosméticos con presencia de lengua inglesa}

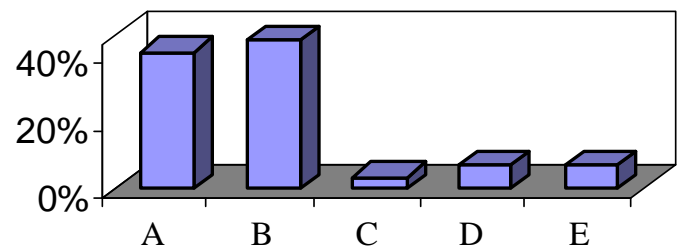

A - El envase ocupa una parte importante en la ilustración y en éste se lee un texto escrito en lengua inglesa. El nombre del producto también se presenta en lengua inglesa: Clinique longstemmed lashes (8) Diminish Anti-wrinkle Retinol Treatment. Estée Lauder (2) Seamless Makeup. Max Factor (1) Superfit Makeup. Clinique (1) TOTAL: 12 anuncios.

B - El nombre del producto se presenta en lengua inglesa y el envase aparece en inglés y francés: Retinol Re-pulp anti-wrinkle care effective zero skin defects. Biotherm (3) Millenium Energist Revitalizing Emulsion. Elisabeth Arden (2) Re-surface. Intense Wrinkle Corrector. Lancôme (3) Soft Matte. Natural Finish Makeup. Estée Lauder (1) Night Sculptor with Pro-Phosphor. Helena Rubinstein (2) TOTAL: 13 anuncios.

C - El nombre del producto se presenta en francés y la ilustración del envase en inglés y francés: Photogenic: light reflective makeup (1) TOTAL: 1 anuncio.

D - El titular del anuncio, coincidente con el nombre del producto, se presenta en lengua inglesa: Pure Color (2) TOTAL: 2 anuncios.

E - La rúbrica del anuncio se presenta en lengua inglesa: Pantene Styling (1) TOTAL: 1 anuncio. 


\section{Comentario}

En nuestro corpus aparecen cuarenta anuncios de cosméticos y treinta de ellos recurren a la utilización de la lengua inglesa de la manera que hemos indicado en el gráfico anterior. Dentro de los diez anuncios de cosméticos que no recurren a la lengua inglesa, podemos observar que existen diferentes marcas que promocionan sus productos utilizando el francés: Eau Dynamisante. Eau de Soins. Clarins. Paris. (2) Avec discipline, fini les petits boutons! Payot. París (1) Rasage Precis Peau Sensible. Biotherm homme (1). No obstante, los productos cosméticos que más se publicitan usan mayoritariamente el inglés sin desdeñar un cierto matiz "francés" como ocurre en el siguiente ejemplo: Suractif Retinol Deep Lift. Lancaster (3).

En un anuncio promocional de la gama de productos de Estée Lauder podemos comprobar que todos ellos se comercializan bajo un nombre inglés:

Barra de labios: Re-Nutriv All-Day Lipstick

Maquillaje de base: Double Wear Stay-In Place Makeup FPS 10

Fragancia: Estée Lauder Pleasures Eau de Parfum Spray

Laca de Uñas: Pure Color Nail Lacquer

Hidratante: 100\% Time Release Moisture Creme

Complejo restaurador: Advanced Night Repair Protective Recovery Complex

\section{Anuncios de cosméticos analizados}

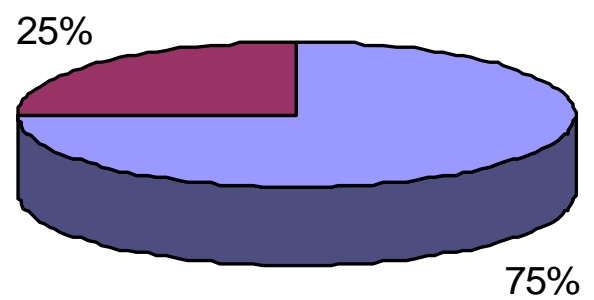

$\square$ utilizan lengua inglesa $\square$ no utilizan lengua inglesa 


\subsubsection{3. - Anuncios de fragancias}

\section{Introducción}

Los anuncios de fragancias son menos informativos que los anuncios de cosméticos ya que resulta bastante difícil publicitar una fragancia aludiendo a cualidades objetivas que la diferencien claramente de sus competidoras. La única información de carácter objetivo que presentan los anuncios de nuestro corpus se refiere al género al que va dirigido el producto: masculino o femenino. Este dato se proporciona explícitamente mediante un mensaje textual o de manera implícita mediante la imagen del modelo que aparece en la ilustración o incluso mediante el diseño del envase. La naturaleza del producto publicitado hace que los anuncios no recurran a textos largos, lo que propicia el uso de la lengua inglesa.

\section{Anuncios de fragancias con presencia de lengua inglesa}

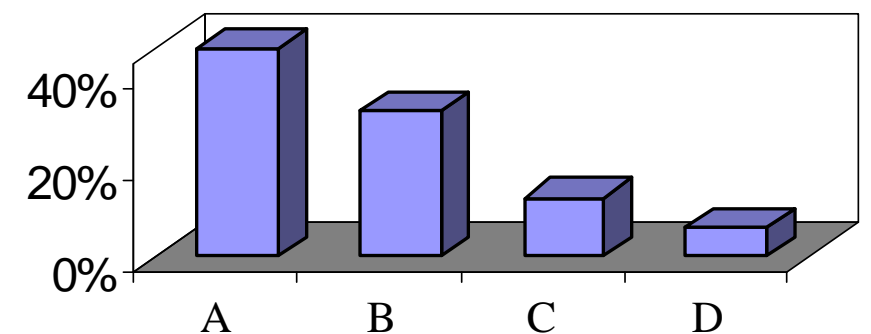

A - Escritos completamente en lengua inglesa: Boss, Bottled. The fragrance from Hugo Boss. (4) Contradiction for men. A fragrance from Calvin Klein. (1) Carolina Herrera. Herrera for men. New York. (1) It only happens in ...Very Valentino. The ultimate Seduction. (1) Introducing the new men's fragrance. Ralph Lauren Romance. For women and now for men. Ralph Lauren Romance. (1) TOTAL: 8 anuncios.

B - El envase ocupa una parte importante en la ilustración. El nombre del producto se presenta, tanto en el texto como en el envase, en lengua inglesa: Allure Chanel (3) Splendor Elisabeth Arden (2) TOTAL: 5 anuncios. 
C - El titular del anuncio se presenta en inglés con traducción al español. El nombre del producto se presenta exclusivamente en inglés: Design your dream. Construye tus sueños. Cerruti Image (2) TOTAL: 2 anuncios.

D - El titular se presenta en español con traducción al inglés: Mango. Haz volar tu imaginación. Let your imagination run wild. (1) TOTAL: 1 anuncio.

\section{Comentario}

En nuestro corpus aparecen cuarenta anuncios de fragancias y dieciseis de ellos recurren a la lengua inglesa de la manera que hemos indicado en el gráfico anterior. Dentro de los veinticuatro anuncios que no utilizan la lengua inglesa existen quince que emplean el francés: Dior. Fahrenheit. L’homme infiniment (5), Jean Paul Gaultier. "Le mâle" (4), etc. Se trata de productos que intentan aprovechar las inferencias positivas que el uso del francés todavía despierta en los destinatarios de anuncios de fragancias. No todos los anuncios que utilizan el idioma francés provienen de Francia, como lo muestran los siguientes ejemplos: Giorgio Armani. Eau pour homme (1) Kenzo. Pour Homme (2).

\section{Anuncios de fragancias analizados}

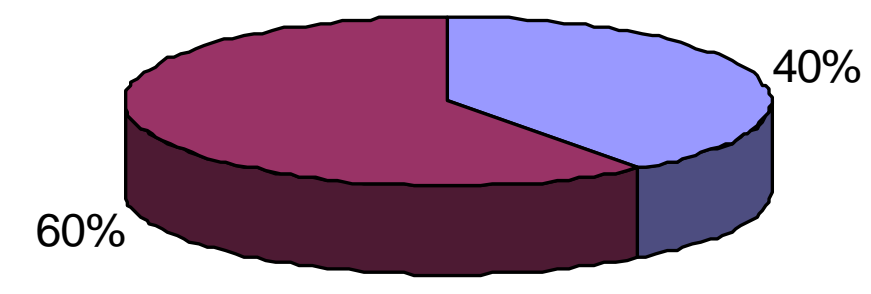

utilizan lengua inglesa $\square$ no utilizan lengua inglesa 


\subsubsection{4. - Anuncios de relojes}

\section{Introducción}

Todos los anuncios de este apartado hacen referencia explícita al país originario del producto, Suiza, que es mundialmente conocido por el prestigio de sus relojes. Este país también se caracteriza por su multilingüismo, hecho que no se ve reflejado en los anuncios examinados que optan mayoritariamente por la lengua inglesa. Sólo existe un caso en el que la rúbrica se redacta en francés: Longines. L'elegance du temps depuis 1832, aunque en este mismo anuncio tanto el titular - Elegance is an attitude - como el modelo de reloj que se publicita - Longines Position - se presentan en inglés.

\section{Anuncios de relojes con presencia de lengua inglesa}

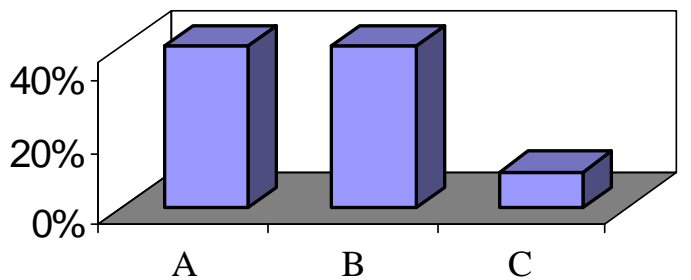

A- El titular del anuncio se presenta en lengua inglesa: Maurice Lacroix. Tomorrow's classics. (2) Elegance is an attitude. Longines (5) Life - Lifestyle Baume \& Mercier (1) Hublot classic. A sensational feeling (1) TOTAL: 9 anuncios

B - La rúbrica del anuncio se presenta en lengua inglesa: Omega. My choice (3) Tissot. Swiss watches since 1853 (1) Rado Switzerland (1) Swatch irony. Time is what you make of it (4) TOTAL: 9 anuncios.

C - El nombre del modelo se presenta en inglés: Longines position (1) Rado Cerix (1) TOTAL: 2 anuncios. 


\section{Comentario}

Los veinte anuncios de relojes que componen nuestro corpus utilizan en alguna parte de su estructura la lengua inglesa. A la hora de presentar los diferentes modelos, estos anuncios recurren al inglés bien de forma directa - Seamaster Professional - bien de forma indirecta como, por ejemplo, mediante la utilización de un sufijo de vinculación anglosajona: Rado Cerix. En algunas ocasiones también en la ilustración se aprecia la presencia de la lengua inglesa: en la vela de un barco se puede leer Omega: Official Timekeeper America's Cup. Cuando la rúbrica hace refencia al lugar de procedencia del producto siempre se recurre al inglés: Geneve, Switzerland, Swiss made, Swiss made since 1848 , etc.

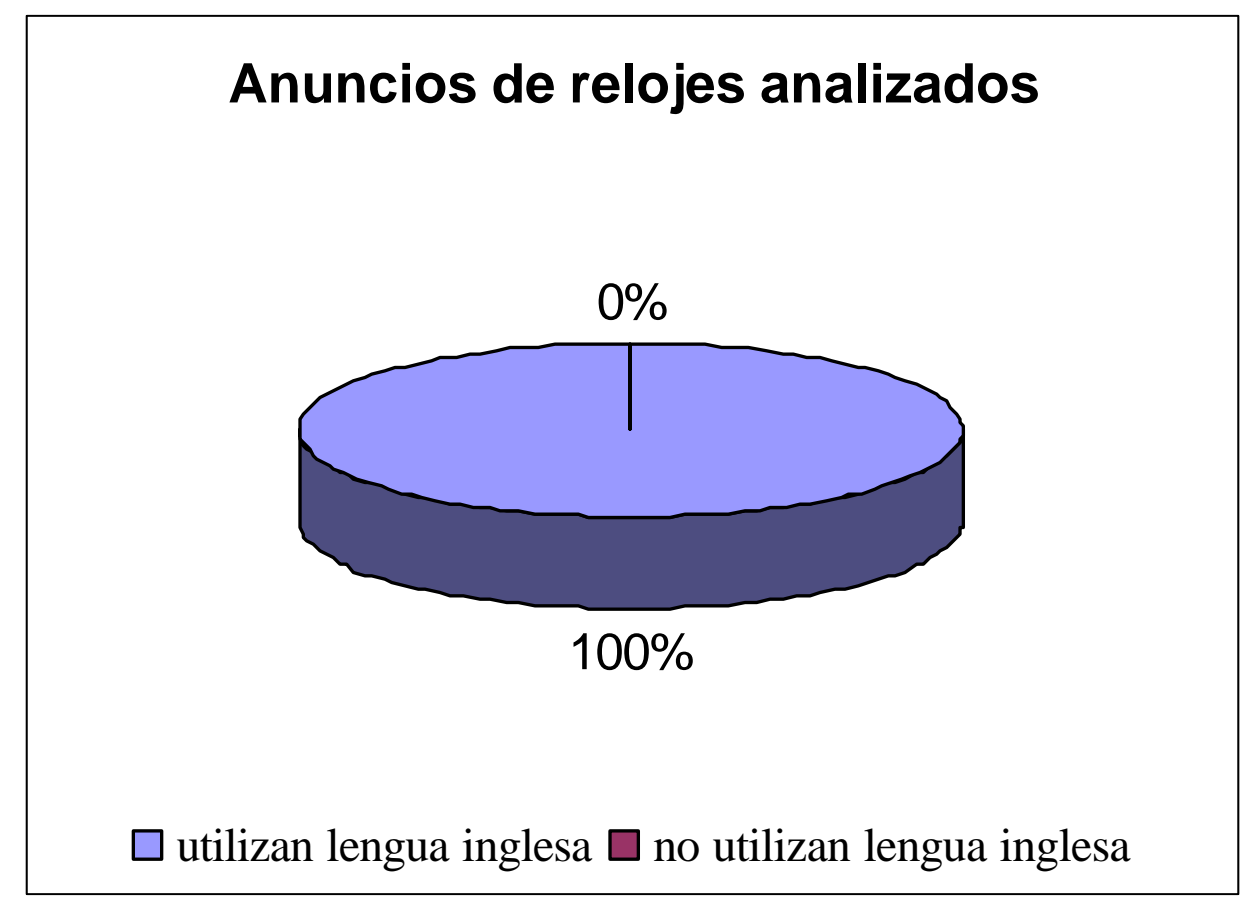

\subsubsection{5. - Anuncios de Moda}

\section{Introducción}

Hemos englobado dentro de esta categoría los anuncios que publicitan prendas de vestir, zapatos y establecimientos de venta de ropa. En nuestro corpus observamos que los anuncios de zapatos tienden a mostrar una naturaleza más informativa que los anuncios de 
ropa: los primeros suelen llevar un cuerpo de texto describiendo las características del producto mientras que los segundos basan muy frecuentemente su estrategia en la "imagen de marca", técnica que se caracteriza por el uso de una ilustración atractiva para el receptor y, en ocasiones, un breve mensaje, escrito en lengua inglesa.

\section{Anuncios de moda con presencia de lengua inglesa}

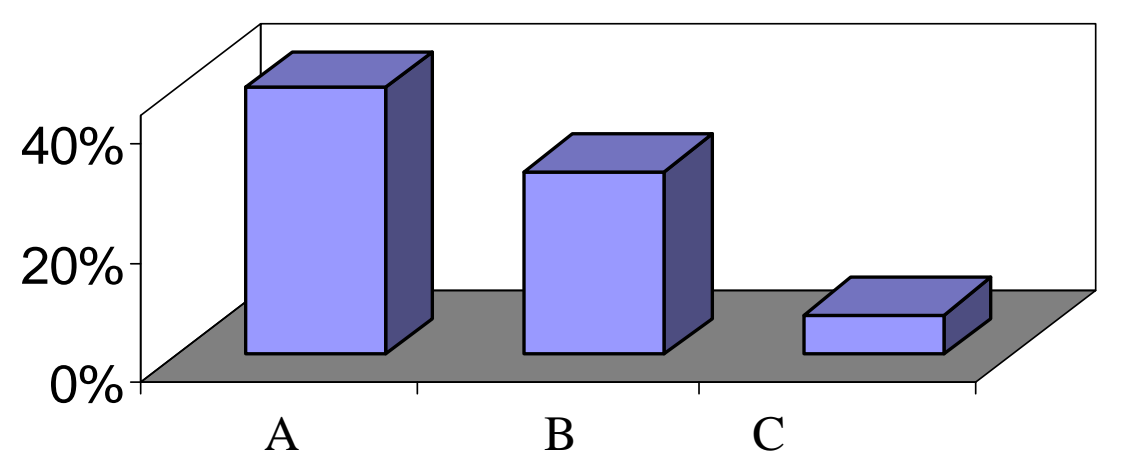

A - Escritos completamente en lengua inglesa: Trusardi Jeans (1) C.P. Company (1) The New Zegna Sport Collection. Zegna Sport (5) Boss. Hugo Boss (3) Betty Barclay. Your Private Dresscode. Shoes. Fragrance. Accessories. Fashion. (1) Genfins (1) D6 Street Pant. Dockers Khakis for Women. No restrictions. (1) Tommy Hilfiger. Men (2) Armani Jeans (1) Wind, Fresh, Different, Light. Natural Life and Style. Panama Jack (1) Tod's (1) TOTAL: 18 anuncios.

B - Anuncios que combinan lengua inglesa y lengua española en el titular del anuncio: Thermal Dry-Fit Top. Tu propia capa protectora antiadherente (2) Boxley. Verano 2000 (1) Springfield. Urban Fusion. Primavera verano 00 (1) Members of the Mephisto movement (...) Finest walking shoes (2) Keep Walking. Siga caminando con el comfort total de Clarks. Clarks England (3) TOTAL: 9 anuncios.

C - Anuncios cuyo único texto es la marca del producto: Ralph Lauren. (2) TOTAL: 2 anuncios. 


\section{Comentario}

En nuestro corpus aparecen cuarenta y cinco anuncios de moda y veintinueve de ellos recurren a la utilización de la lengua inglesa de la manera que hemos indicado en el gráfico anterior. Debemos destacar que la combinación de lengua inglesa y lengua española en un mismo texto no resulta extraña en el lenguaje publicitario, como lo muestra la siguiente nota a pie de página publicada en un anuncio de la empresa de calzado española Camper: "Brothers by Camper. Cosido $360^{\circ}$, horma ultra-amplia, Takeoff system, plantilla acolchada anatómica: Comfort With Imagination. Información Camper 900600 606. www.camper.es."

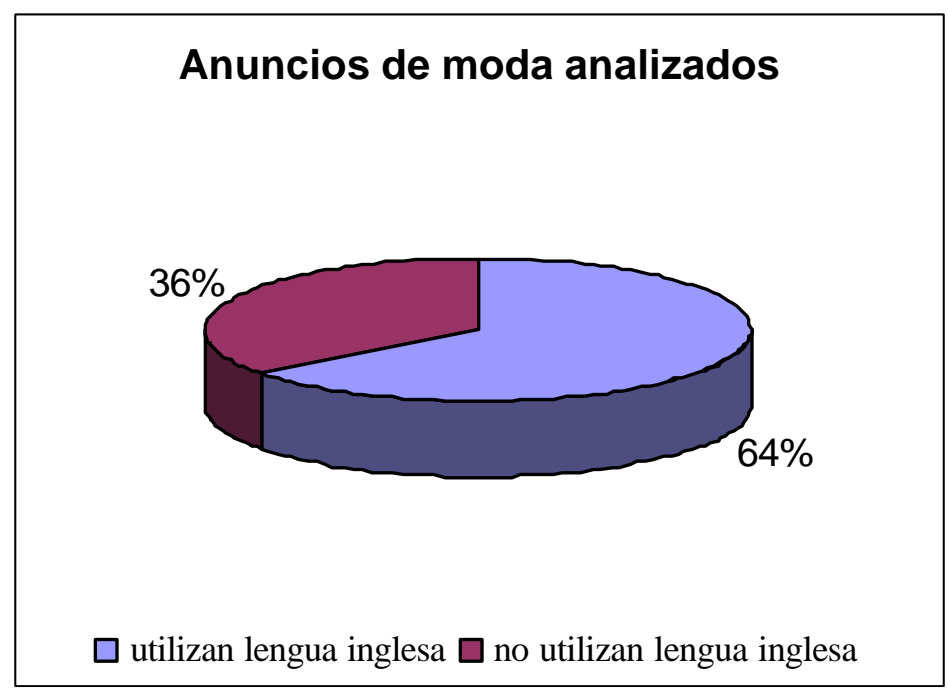

\subsubsection{6. - Móviles e informática}

\section{Introducción}

Al igual que ocurre en las ofertas de empleo, la publicidad relacionada con las nuevas tecnologías es rica tanto en anglicismos como en mensajes escritos en lengua inglesa. En nuestro corpus hemos encontrado los siguientes anglicismos crudos: web, online, kit de conexión, vibracall, función easytext, dual band, X press-on Covers, WAP (Wireless Aplication Protocol) y Outsourcing. A su vez, los operadores de telefonía que prestan sus servicios en España no dudan en recurrir a nombres de clara filiación 
anglosajona para identificar su empresa - como Airtel, Jazztel, etc.- o para presentar sus productos: Movistar, Moviline, etc.

\section{Anuncios de móviles e informática con presencia de lengua inglesa}

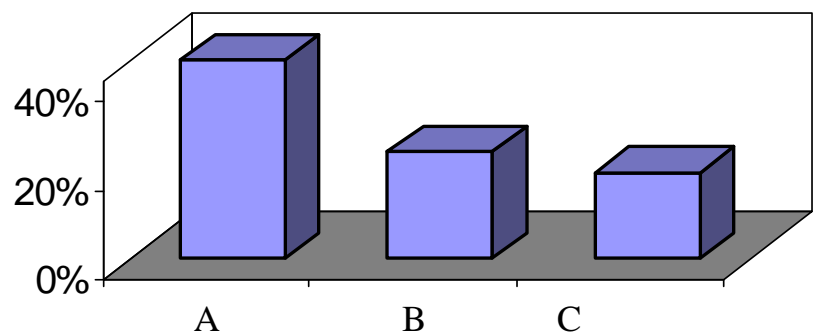

A - La rúbrica del anuncio se presenta en lengua inglesa: Mitsubishi Electric (1) Nokia. Connecting People (17) Gertronics. Building Futures (3) World online. The Internet Communication Company (2) TOTAL: 23 anuncios

B - Anuncios que publicitan un producto con nombre en inglés: Telefónica Movistar (2) Movistar Plus de Telefónica (1) Web Touch One de Alcatel (1) Microsoft msn.(5) Web business (1) TOTAL: 10 anuncios

C - Anuncios con titular y traducción en inglés: What do you wanna do? ¿Qué quieres hacer? Wanadoo (8) TOTAL: 8 anuncios

\section{Comentario}

En nuestro corpus aparecen cuarenta y ocho anuncios de móviles e informática y cuarenta y uno de ellos recurren, en mayor o menor medida, a la lengua inglesa. A la vista de los resultados no resultaría descabellado afirmar que es en el ámbito de las nuevas tecnologías donde encontramos un mayor influjo lingüístico inglés tanto en los anuncios escritos en español, con abundancia de anglicismos, como en anuncios donde se utiliza la lengua inglesa. Sin embargo, debemos señalar que debido a la necesidad de aportar al texto un cierto carácter informativo, existe una acusada tendencia a amalgamar ambos códigos. 


\section{Anuncios de móviles e informática analizados}

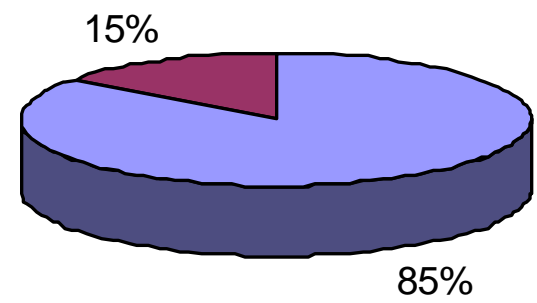

$\square$ utilizan lengua inglesa $\square$ no utilizan lengua inglesa

\subsubsection{7. - Anuncios de automóviles}

\section{Introducción}

Como ya hemos dicho, la propia naturaleza del producto publicitado marca el diferente papel que desempeña la lengua inglesa en su promoción. Los anuncios de automóviles no se caracterizan por recurrir en demasía al anglicismo y su uso se reduce a la presentación de ciertas características técnicas de carácter novedoso: Airbag, ABS (anti blocking system), cambio multitronic, función softtouch, sistema assyst, etc.Tampoco es muy abundante el uso de mensajes en lengua inglesa, normalmente restringidos a la presentación de algunos modelos tradicionalmente dirigidos a los clientes más jóvenes y a la redacción de la rúbrica.

\section{Anuncios de automóviles con presencia de lengua inglesa}

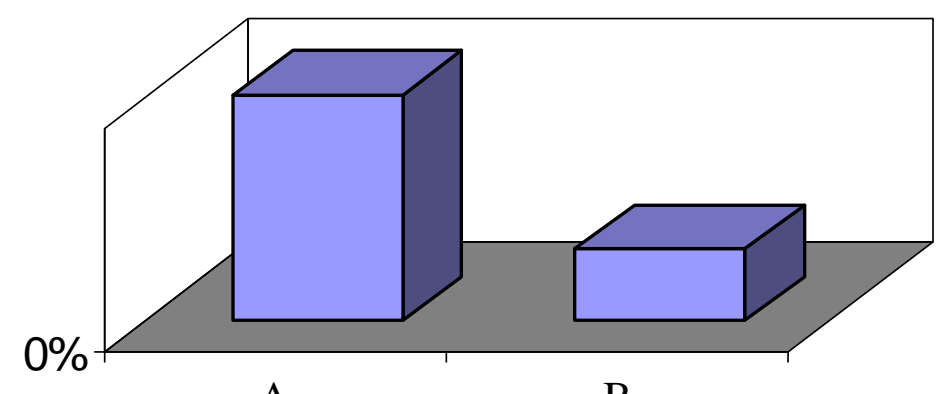

A

B 
A - Anuncios que publicitan el modelo de automóvil utilizando la lengua inglesa: Mitsubishi Space Wagon (1) Clio dTI Tech Road (1) Clase A fashion. Mercedes (1) Atos Prime. Hyundai (7) Smart (2) TOTAL: 12 anuncios.

B - Anuncios que presentan la rúbrica del anuncio en lengua inglesa: Clio. World Wide Car (1) Mitsubishi Motors (1) TOTAL: 2 anuncios $^{80}$.

\section{Comentario}

En nuestro corpus aparecen treinta y un anuncios de automóviles y doce de ellos recurren a la utilización de la lengua inglesa de la manera que hemos indicado en el gráfico anterior. Podemos comprobar que no se trata de una presencia muy destacada en la estructuración general del texto publicitario y, por primera vez, los anuncios que no utilizan la lengua inglesa sobrepasan a los que sí recurren a ella.

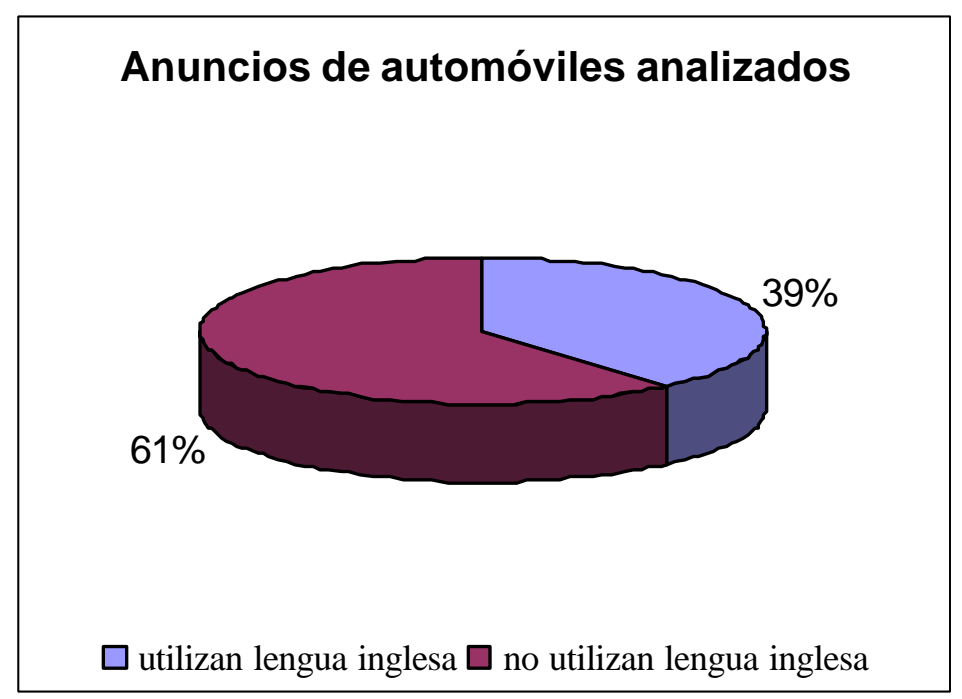

\subsubsection{8. - Anuncios de bebidas}

\section{Introducción}

Los datos que arroja el análisis de nuestro corpus de anuncios muestran que la publicidad de bebidas alcohólicas es muy abundante en los suplementos dominicales que

\footnotetext{
${ }^{80}$ En este apartado los anuncios de nuestro corpus que presentan la rúbrica en lengua inglesa también recurren al inglés para presentar el modelo publicitado.
} 
acompañan a la prensa española siendo su presencia únicamente superada por un producto de reciente aparición: los teléfonos móviles. Su destacada presencia se debe tanto a las restricciones legales existentes en la publicidad de bebidas de alta graduación emitida en televisión como al perfil de los lectores de los dominicales. Tal como ocurría en los anuncios de cosméticos el envase y el etiquetado del producto forman parte del texto del anuncio y en la mayor parte de los casos se aprovechan para introducir un mensaje en lengua inglesa.

\section{Anuncios de bebidas con presencia de lengua inglesa}

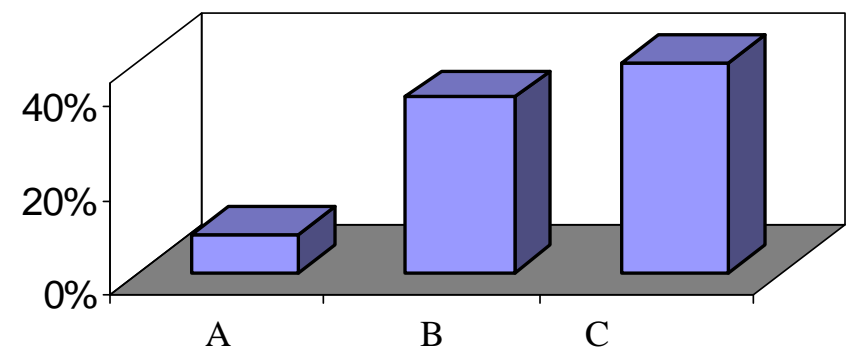

A - Anuncios escritos completamente en lengua inglesa ${ }^{81}$ : Triple Distillation. Triple Purity. No imperfections. Triple distilled for ultimate purity. Smirnoff (1) Absolut Aromatherapy. Absolut Vodka. ${ }^{82}$ (1) TOTAL: 2 anuncios.

B - Anuncios que presentan en el titular del anuncio una combinación de lengua inglesa y lengua española: Absolut Tribute. Homenaje a la trayectoria de Pedro Almodovar (1) Más hielo, por favor. Chivas Regal $12{ }^{83}$. When you know (1) El móvil. El busca. El fax. El correo electrónico. ¿ .. y que hay del interruptor para desconectar ...?

Chivas Regal 12. When you know (1) La pasión no entiende de normas. Chivas Regal

\footnotetext{
${ }^{81}$ A excepción del siguiente enunciado que siempre aparece en español en las bebidas alcohólicas de alta graduación: "Bebe con moderación. Es tu responsabilidad."

${ }^{82}$ La botella de Absolut, que ocupa la mayor parte de la ilustración, es una constante en todos sus anuncios de este producto. En ella se puede leer el siguiente texto: "Country of Sweden. This superb vodka was distilled from grain grown in the rich fields of southern Sweden. It has been produced at the famous old distilleries near Ahus in accordance with more than 400 years of Swedish tradition. Vodka has been sold under the name of Absolut since 1879. Imported. (...)"

${ }^{83}$ Todos los anuncios de Chivas Regal 12 llevan el siguiente pié de página: "Chivas Regal 12 Year Old Worldwide Blended Scotch Whisky $40 \%$ alcohol by Volume ( 80 proof) Chivas Bros. Import Co., New York,NY."
} 
12. When you know (1) Y pensar que hay gente que prefiere tener relaciones virtuales ... Chivas Regal 12. When you know (1) Pure \& Harmony. El único que es único (1) Pure \& Vision. El único que es único (1) Pure \& Emotion. El único que es único (2) TOTAL: 9 anuncios.

C - Anuncios que utilizan la etiquetación del producto, escrita en lengua inglesa, para su presentación: El 70\% del cuerpo es agua. Ya está bien, ¿no? Deward’s. Established 1846. Finest Scotch Whisky. Product of Scotland. White Label brand blended and bottled in Scotland by John Dewar \& Sons. (4) Algo mágico envuelve la vida en Speyside. Las lágrimas de los dioses. Single Malt Cardhu. Highland Scotch Whisky. (...) (2) Momentos de inspiración. Ballantine's Ballantine's finest. Established 1827. Scotch Whisky. (...) (7) TOTAL: 13 anuncios.

\section{Comentario}

Dentro de los cuarenta y cinco anuncios de bebidas que componen nuestro corpus, nos encontramos con 25 que recurren, en alguna parte del texto, al uso de la lengua inglesa. Su utilización es muy frecuente en las bebidas alcohólicas que no son originarias de nuestro país y que son mayormente consumidas por gente joven: Vodka, Ginebra y Whisky. Al contrario, su presencia es casi inexistente en licores más tradicionales y más demandados por la población adulta: anís, ponche, Licor 103, coñac.

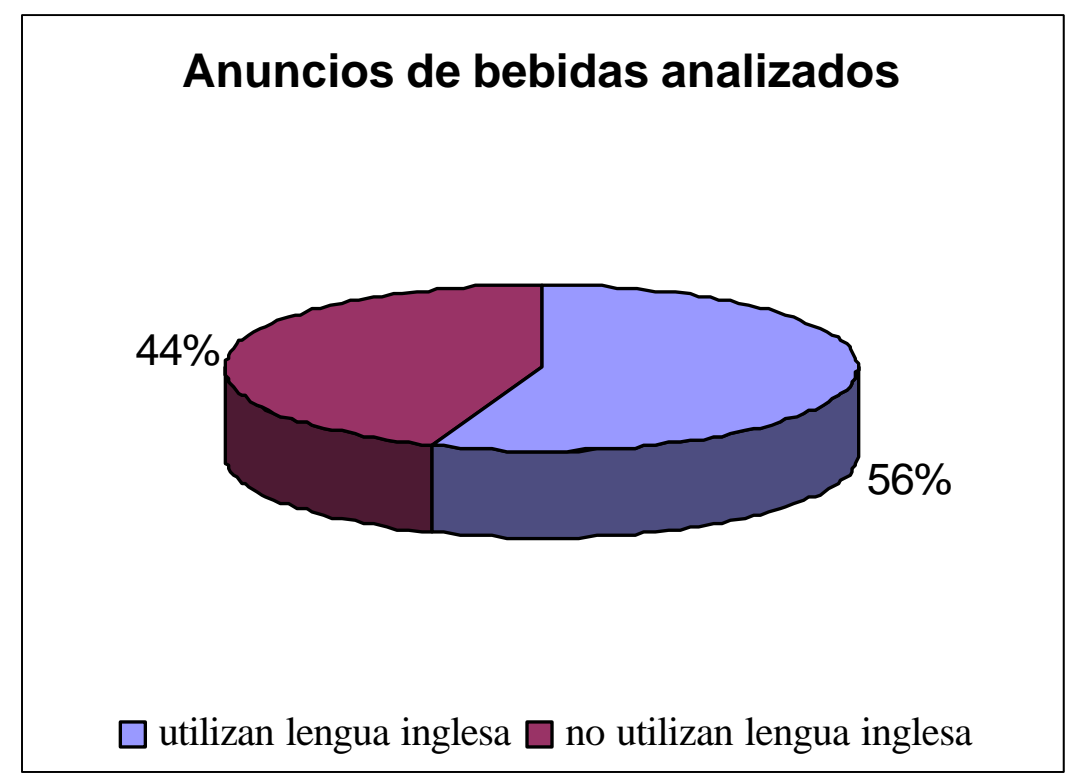




\subsubsection{9. - Anuncios de tabaco}

\section{Introducción}

Una de las características más destacadas de la publicidad de tabaco se refiere a la preminencia de la imagen sobre el componente lingüístico del anuncio. Así, buena parte de los anuncios, especialmente los de tabaco rubio, presentan en la ilustración una situación que el destinatario percibe como típicamente americana acompañada de un texto que no suele sobrepasar las cuatro palabras, una de las cuales es el nombre del producto que, a su vez, muestra una clara filiación anglicista: Winston, Chesterfield, Lucky Strike, West, Silk Cut, Camel, etc.

\section{Anuncios de tabaco con presencia de lengua inglesa}

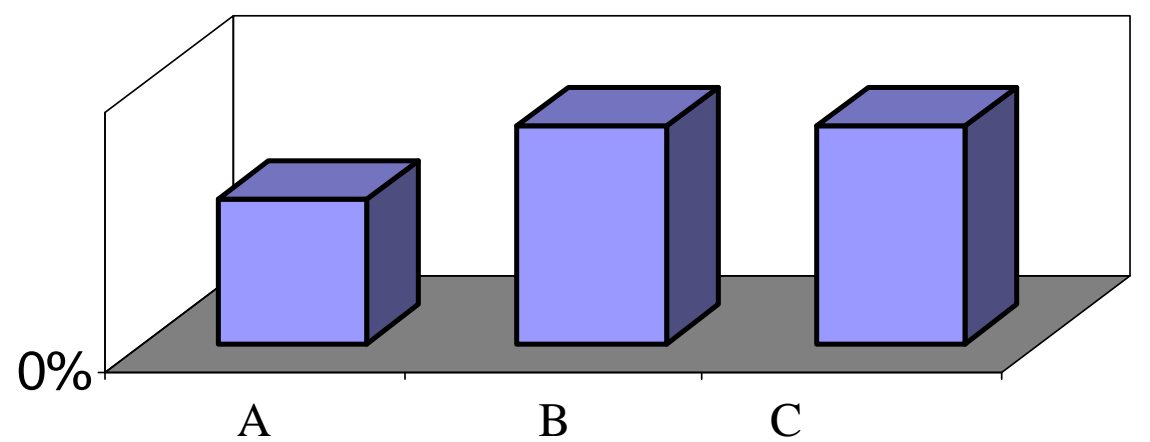

A - Anuncios escritos completamente en lengua inglesa: Malboro Country (1) Malboro Lights (1) TOTAL: 2 anuncios.

B - Anuncios que presentan en el titular del anuncio una combinación de lengua inglesa y lengua española: Provocación. Bolero Cigar Club. Chicago (1) Carisma. Desoto Cigar Club. New York (1) Audacia. Bay City Lounge. San Francisco (1) TOTAL: 3 anuncios.

C - Anuncios que integran el término inglés que nombra la marca en el titular: Siempre hay tiempo para un Camel rapidillo (1) Cuidado, no rompas tus Camel (1) No olvides tus Camel en el guardarropa (1) TOTAL: 3 anuncios. 


\section{Comentario}

En nuestro corpus aparecen doce anuncios de tabaco y ocho de ellos recurren a la utilización de la lengua inglesa de la manera que hemos indicado en el gráfico anterior. Resulta significativo que el texto más largo en los anuncios de tabaco corresponda a la advertencia legal que obligatoriamente aparece en todos los anuncios de este producto y que dice lo siguiente: "Las Autoridades Sanitarias advierten que el tabaco perjudica seriamente la salud." No obstante, el monopolio que la imagen americana ha ejercido sobre la publicidad del tabaco ha propiciado la aparición de campañas que se distancian de esta estrategia utilizando imágenes de otra procedencia. Un buen ejemplo de esta táctica es la campaña de Ducados identificable por el uso del siguiente eslogan: Sabor latino.

\section{Anuncios de tabaco analizados}

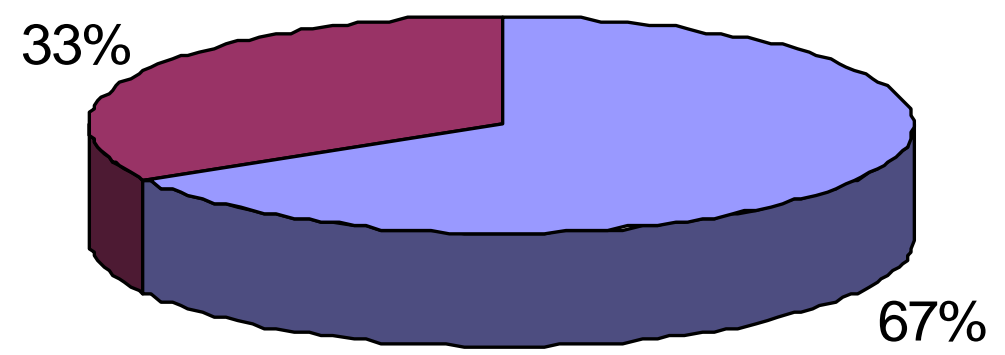

utilizan lengua inglesa $\square$ no utilizan lengua inglesa 
1.7.4. - Conclusiones estadísticas de nuestro estudio

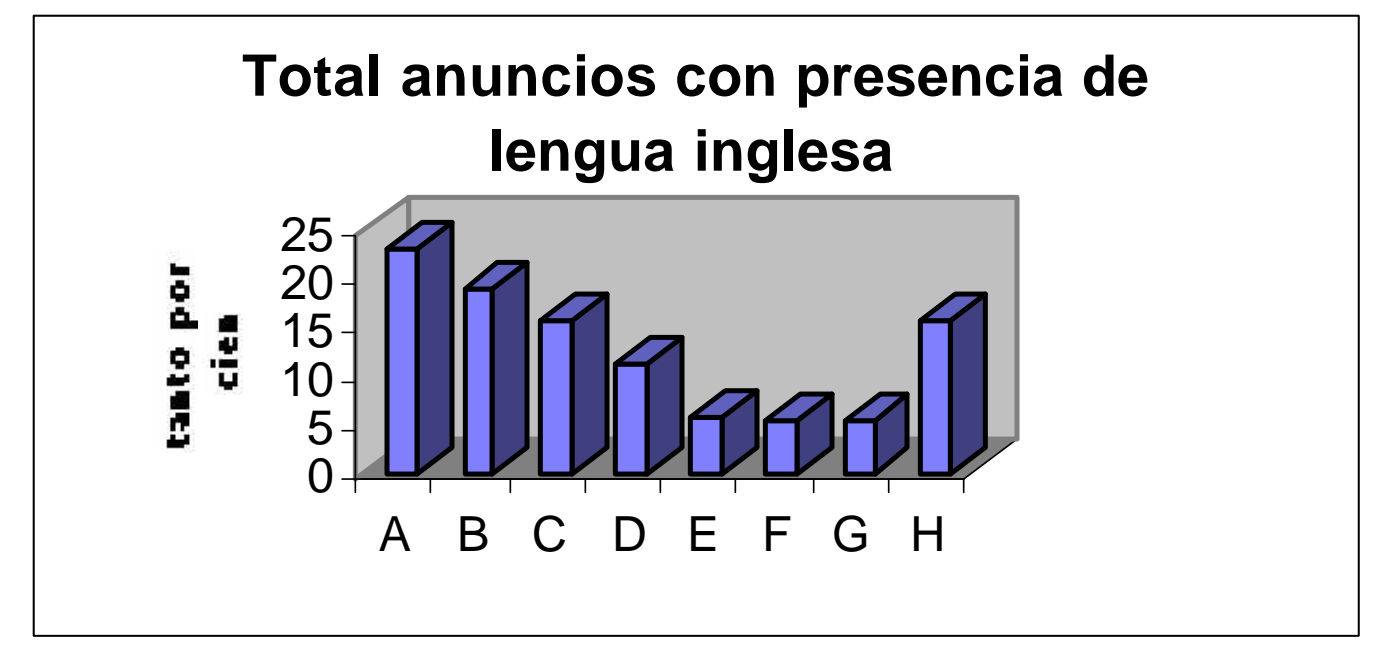

A - El envase o la etiquetación del producto se presentan en lengua inglesa: 44 anuncios

B - La rúbrica del anuncio se presenta en lengua inglesa: 36 anuncios

C - Anuncios exclusivamente redactados en lengua inglesa: 30 anuncios

D - Anuncios que presentan en el titular del anuncio una combinación de lengua inglesa y lengua española: 21 anuncios

$\mathbf{E}-$ El titular del anuncio se presenta en lengua inglesa: 11 anuncios

F - El titular del anuncio y el nombre del producto se presentan en inglés: 10 anuncios

G - El titular del anuncio y el nombre del producto se presentan en inglés con traducción al español: 10 anuncios

H - Otros: 30 anuncios

\section{Total de anuncios estudiados}

$42 \%$

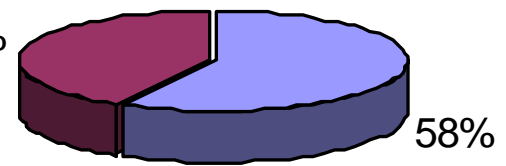

$\square$ utilizan lengua inglesa $\square$ no utilizan lengua inglesa 


\section{MODELOS DE ANÁLISIS LINGÜíSTICO APLICADOS A LA COMUNICACIÓN PUBLICITARIA}

Tradicionalmente, el modelo del código ha constituido el paradigma dominante en los estudios lingüísticos aplicados al ámbito publicitario. Todos ellos se caracterizan por partir de la siguiente premisa: la comunicación se consigue mediante la codificación y descodificación de mensajes. La abundancia de este tipo de estudios en el análisis del mensaje publicitario se puede explicar tanto por su aparente simplicidad como por un cierto recelo a aplicar enfoques alternativos a una situación comunicativa ya complicada por su propia naturaleza ${ }^{84}$. A los anteriores factores debemos añadir el poderoso influjo ejercido por diversas teorías que todavía hoy en día asumen que la comunicación lingüística se produce mediante un proceso de codificación y descodificación: "The view of linguistic communication as achieved by encoding thoughts in sounds is so entrenched in Western culture that it has become hard to see it as a hypothesis rather than a fact" (Sperber y Wilson 1995: 6).

Los modelos semióticos de análisis de la comunicación humana y publicitaria propuestos por sociólogos como Levi-Strauss, filósofos como Umberto Eco y teóricos de la literatura como Roland Barthes han ayudado a conocer diferentes aspectos de la comunicación, destacando ciertos rasgos comunes - tanto lingüísticos como no lingüísticos - existentes en distintas situaciones comunicativas. Sin embargo, debemos destacar que parten de una base errónea al considerar que todo proceso comunicativo se 
lleva a cabo mediante un procedimiento de codificación-descodificación. La presencia de elementos recurrentes en la comunicación publicitaria no constituye un código, como defienden los semiólogos, y su análisis únicamente sirve para definir un estilo particular caracterizado por una función comunicativa específica:

las descripciones de elementos recurrentes en las imágenes y en los textos escritos en los anuncios publicitarios sirven exclusivamente para caracterizar un género, definido por una función comunicativa, la publicitaria, constituida socialmente como fenómeno tanto lingüístico como extralingüístico. A su vez, estos elementos revelan la intención comunicativa del emisor y en cuanto que pueden constituir una opción, sirven para caracterizar un estilo comunicativo. (Corrales 1996: 3)

Los enfoques basados en el modelo del código han dejado preguntas muy importantes sin responder. No han llegado a aportar una explicación contrastada sobre la manera en que se llena el vacío existente entre el mensaje emitido como significante portador de un determinado significado - y el mensaje recibido como significado. $\mathrm{Su}$ planteamiento se centra en el estudio del texto en sí ignorando el indispensable papel que juega el contexto comunicativo y aspectos como la negociación que se produce entre emisor y destinatario para dotar de significado a cualquier tipo de texto son completamente ignorados. En este apartado llevaremos a cabo un breve repaso de algunos de los modelos del código que han resultado más influyentes en el estudio de la comunicación publicitaria prestando una especial atención tanto a sus aciertos como a sus carencias. Comenzaremos por el modelo comunicativo de la teoría matemática de la información y concluiremos con el modelo semiótico-textual.

\footnotetext{
${ }^{84}$ Nos referimos a una tendencia general ya que existen ciertos autores que, en mayor o menor medida, aplican otros modelos como el propuesto por el análisis del discurso. Uno de los ejemplos clásicos es el libro de Cook The discourse of Advertising publicado en 1992.
} 


\section{1. - ANTECEDENTES DEL MODELO DEL CÓDIGO}

\subsection{1. - El modelo comunicativo de la teoría matemática de la información}

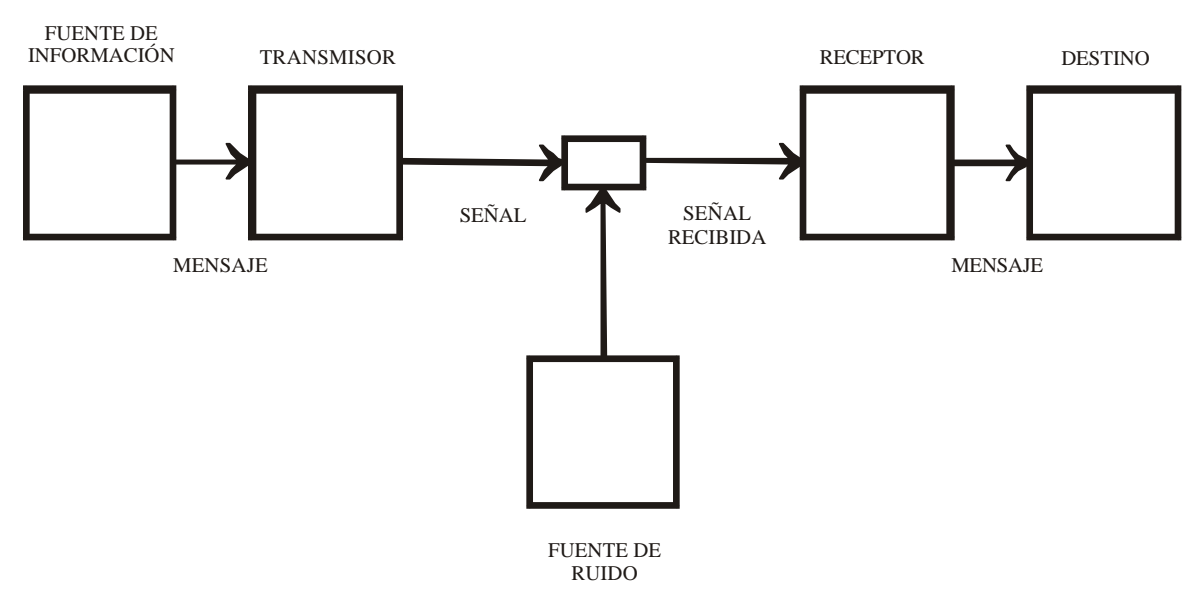

Figura 1 (Shannon y Weaver 1981: 23)

El esquema que podemos ver en la figura 1 puede considerarse el precursor de todos los posteriores modelos del código. Sus autores parten del fenómeno comunicativo que ocurre en el ámbito de las telecomunicaciones y muestran cómo un mensaje que se origina en una fuente de información llega al destinatario mediante un proceso de comunicación. La teoría matemática de la información tiene como objetivo "to speed up message transmission, reduce information distorsion and loss and to increase the general performance of the information transmission process" (Wolf 1987: 127). El esquema aquí reproducido se describe de la siguiente manera:

En todo proceso comunicativo existe siempre una fuente o manantial de la información, desde la cual, a través de un aparato transmisor es emitida una señal; esta señal viaja a través de un canal a lo largo del cual puede ser interferida por un ruido. Al salir del canal, la señal es recogida por un receptor que la convierte en un mensaje. Como tal, el mensaje es comprendido por el destinatario. (Eco 1972: 10)

La transmisión de información por medio del correo electrónico puede servirnos como ejemplo del funcionamiento de este modelo. La fuente de información y el destinatario podrían ser dos personas que están trabajando con un ordenador personal. El 
mensaje puede ser un texto, una imagen, un gráfico, etc. mientras que tanto el transmisor como el receptor son dos ordenadores. El canal sería Internet y la señal estaría formada por las ondas electromagnéticas emitidas por un ordenador y recibidas por otro u otros ordenadores ${ }^{85}$.

El modelo que acabamos de describir ha tenido una presencia constante en toda clase de estudios comunicativos debido sobre todo a su simplicidad y adaptabilidad a disciplinas muy heterogéneas: matemáticas aplicadas, telecomunicaciones, lingüística, teoría de la comunicación, etc. En la investigación de la comunicación de masas, el modelo informacional ${ }^{86}$ también ha sido "the real dominating paradigm, rarely questioned and yet frequently used: and in this, empirical tradition and critical research have followed the same path" (Wolf 1987: 134).

Sin embargo, la teoría matemática de la comunicación tiene una limitación muy evidente que parte de lo que podríamos denominar el problema del código. Shannon y Weaver (1981) distinguen claramente entre comunicación - transferencia de información entre dos polos medible en términos cuantitativos - y significado, irrelevante para su modelo comunicativo:

The code which interests information theory (...) is a purely syntactic system, an organizing system whose own relevance doesn't provide for the problem of the meaning of the message, that is, the most specifically communicative dimension. (Wolf 1987: 131)

Este modelo se centra exclusivamente en los aspectos vinculados al significante, dejando totalmente a un lado el análisis del significado, aspecto esencial para el estudio de todo proceso comunicativo. En su libro Relevance. Communication and cognition, Sperber y Wilson describen el funcionamiento del modelo informacional sin precisar el concepto de código que atribuyen a Shannon y Weaver: "A widely quoted diagram of Shannon and Weaver (...) shows how communication can be achieved by use of a code"

\footnotetext{
${ }^{85}$ En el correo electrónico, el canal - agrupado bajo el nombre de internet - puede estar formado por uno o varios de estos elementos: un cable eléctrico, el aire o la fibra óptica. La señal es distinta dependiendo del canal por el que se transmita: si circula por un cable eléctrico la señal será eléctrica (u ondas electromagnéticas), si circula por el aire la señal serán ondas electromagnéticas y si circula por fibra óptica, la señal será óptica.

${ }^{86}$ Wolf denomina modelo informacional al modelo comunicativo de la teoría matemática de la información.
} 
(1995: 4). Eguizabal recalca que la teoría matemática de la comunicación no llega a hacer mención explícita del uso de códigos, importante hecho que han pasado por alto muchos estudiosos del tema, sino que se limita exclusivamente a presentar un sistema de reglas mediante el cual se atribuyen distintos valores - que no significado - a las señales. El modelo comunicativo expuesto por Shannon y Weaver "ha desplazado el sentido originario de compartir que tenía la comunicación por el de transmitir, y su esfuerzo está dirigido a una transmisión óptima de los mensajes: mejorar la velocidad, reducir distorsiones, etc.” (Eguizabal 1992: 58).

\subsection{2. - El modelo de Lyons}

Lyons reconoce que su teoría de la comunicación está basada en el diagrama elaborado por Shannon y Weaver y afirma que esquemas muy similares han sido publicados por psicólogos y lingüistas - entre los que destacamos a Roman Jakobson ${ }^{87}$ que han trabajado en el campo de la comunicación en la década de los años cincuenta y sesenta. También observa que el modelo comunicativo de la teoría matemática de la información tiene una aplicabilidad mucho más amplia que la inicialmente presentada por Shannon y Weaver:

It is important to realize that the terms in question are of much wider applicability than their origin in communications-engineering might suggest; and they should not be thought of as referring solely to some electrical, mechanical or electronic system of signal transmission. (Lyons 1977: 36)

Aunque reconoce sus limitaciones ${ }^{88}$, considera que es un esquema adecuado para explicar la comunicación humana no restringida a la pura comunicación lingüística. De una manera básica, Lyons describe su modelo de comunicación de la siguiente manera:

\footnotetext{
${ }^{87}$ Jakobson (1961: 74) encuentra diversos puntos de contacto entre la lingüística y la teoría matemática de la comunicación proponiendo una integración entre ambas disciplinas. No obstante, su modelo comunicativo tiene las mismas carencias que el modelo informacional propugnado por Shannon y Weaver (véase Vazquez y Aldea 1991: 30).

${ }_{88}$ Como principales carencias destaca que se trata de un modelo excesivamente esquemático e idealizado y que ha sido concebido principalmente para explicar lo que denomina factual information.
} 
"The message originated by $\mathrm{X}^{89}$ (source) is encoded by the transmitter into a signal. The signal is sent over a particular communication channel to the receiver. The receiver decodes the signal into a message and passes the message on to Y (destination) $)^{90}$."

Signal transmitted Received signal

X ------- Transmitter --------- Channel ---------- Receiver ---------- Y

Source of noise

Figura 2 (Lyons 1977: 36)

Una vez expuesto el esquema, Lyons pasa a describir su funcionamiento en la comunicación de lo que denomina factual o propositional information. El emisor (X) tiene a su disposición un conjunto de proposiciones (P1, P2, P3, .. Pn), selecciona una de ellas (Pi) y la codifica en una señal que se transmite mediante un canal. La señal se descodifica y llega al receptor (Y) en forma de mensaje:

Provided that the proposition, $P i$, is not already included in $\mathrm{Y}^{\prime}$ s store of knowledge and is not in conflict with any of the other propositions known to $\mathrm{Y}$ (or held to be true by Y), it will be accepted and stored by him; and Y's store of factual knowledge (or belief) will be thereby augmented. (...) If $\mathrm{Y}$ is already in posesion of $P i$, the signal encoding $P i$ (...) is uninformative and Y's state of knowledge is unaffected. But if $P i$ is in conflict with any other proposition, $P j$, in $\mathrm{Y}^{\prime}$ s possession, $\mathrm{Y}$ can do one of various things:

${ }^{89}$ En el caso de la comunicación humana, tanto las funciones de la fuente y el transmisor como las del receptor y el destinatario las lleva a cabo el cerebro humano: "Not only is it the case that the source and transmitter, as well as the receiver and destination, may be parts of the same machine or organism, but they may be interconnected by making use of the same processing mechanisms" (Lyons 1977: 37).

${ }^{90}$ Lyons defiende que su modelo de comunicación no se restringe a la comunicación entre un emisor y un receptor ya que también le parece apropiado para explicar otras formas de comunicación: "Not only one-to-one communication is possible, but also one-to-many and, in principle, many-to-one communication. Of these, the former type of communication where one source, $\mathrm{X}$, sends the same message simultaneously to several destinations, $\mathrm{Y}, \mathrm{Y}^{\prime}, \mathrm{Y}^{\prime \prime}$, etc., is common enough: $X$ might be giving a lecture to a group or talking to a number of friends " (1977: 38). 
he can reject $P i$ as untrue; he can store $P i$ in place of $P j$, which it conflicts with; he can suspend judgement, storing in effect the information that either $P i$ or $P j$ (but not both) is true. ( Lyons 1977: 39)

El modelo de Lyons se interesa por el análisis del significado de los enunciados y más concretamente por la forma en que interactúa la información nueva transmitida por el emisor con la información que el receptor ya posee. Ello constituye un avance muy significativo respecto a la teoría matemática de Shannon y Weaver. No obstante, el propio Lyons reconoce ciertas carencias en su modelo que él mismo plantea pero no llega a solucionar. Entre ellas cita las siguientes: el modelo del código no soluciona el problema de los distintos grados de accesibilidad que existen en las diferentes proposiciones tanto desde el punto de vista del emisor como del receptor. Tampoco diferencia entre las proposiciones conocidas a priori (que funcionan independientemente de las experiencias personales) y las proposiciones a posteriori (que se construyen atendiendo a nuestras propias vivencias). Dentro del grupo de proposiciones que se consideran empíricamente verdaderas no se distingue entre las que provienen de nuestra propia observación y experiencia inmediata y las que hemos aprendido de otras personas o hemos llegado a ellas mediante un proceso reflexivo.

Lyons considera que todas estas particularidades son realmente relevantes a la hora de asignar un mayor o menor peso a las múltiples interpretaciones que podemos llevar a cabo de los enunciados. Sin embargo, su modelo comunicativo no llega a dar una explicación satisfactoria del proceso de cognición humano por la falta de un análisis profundo de factores tan relevantes como la función del contexto que acompaña a los diferentes enunciados, la actitud y motivación del emisor, las expectativas del receptor, etc. Tampoco se aporta ninguna explicación al incuestionable hecho de que los participantes en el proceso comunicativo tienen un cierto grado de conocimiento mutuo objetivo o no - que se irá contrastando a lo largo del intercambio comunicativo. El receptor está especialmente interesado en todo lo referente a la fiabilidad, sinceridad, finalidad, etc. de su interlocutor ya que ello puede condicionar la aceptación o el rechazo de la proposición planteada.

A modo de conclusión, podemos afirmar que el modelo de Lyons se diferencia del propuesto por Shannon and Weaver en que realmente nos presenta lo que ya puede 
considerarse un modelo del código propiamente dicho: aunque el diagrama que utilizan sea similar, podemos ver que la aplicación que se le da es bastante más ambiciosa al no quedar restringida únicamente a la transmisión de señales por un medio eléctrico, mecánico o electrónico. Lyons atiende tanto a la transmisión del significante como a la interpretación del significado por parte del receptor. Sin embargo, el propio autor reconoce que su modelo tiene carencias importantes que plantea pero no llega a solucionar.

\subsection{3. - Modelos semióticos}

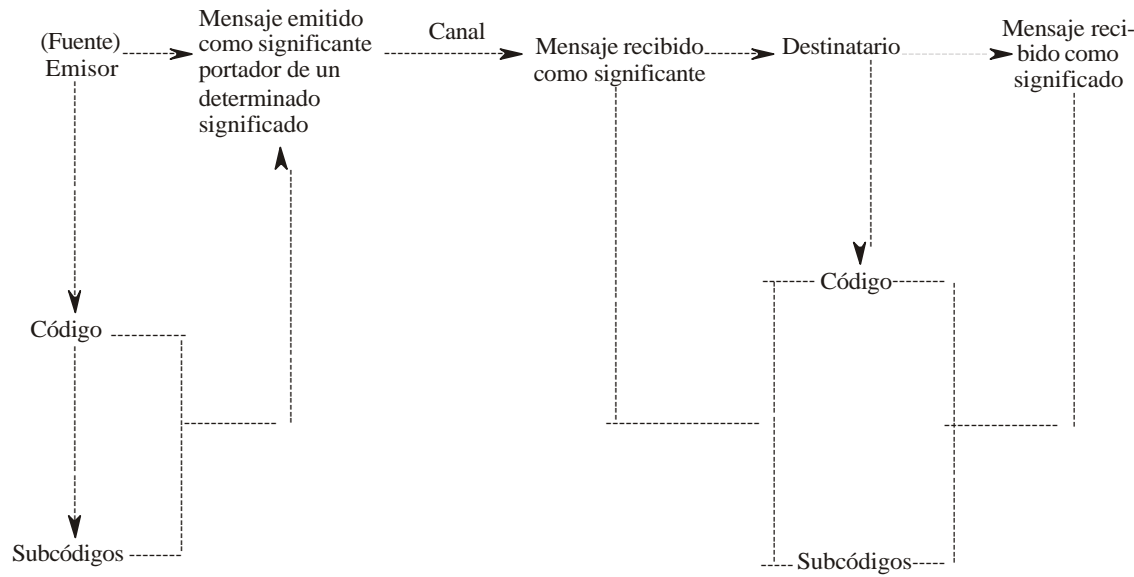

(Eco-Fabril y otros, 1966) (en Wolf, M., 1987, p. 139)

Figura 3

Partiendo del marco general establecido por Lyons y compartiendo criterios básicamente similares se llevan a cabo nuevas reformulaciones, más o menos complejas, de los anteriores esquemas que darán lugar a los diversos modelos del código existentes hoy en día. En las últimas décadas los planteamientos semióticos han tenido una popularidad espectacular en todo lo relativo al estudio de la comunicación humana ${ }^{91}$. Los

\footnotetext{
${ }^{91}$ Sperber y Wilson son muy críticos con los enfoques semióticos de la comunicación: "The recent history of semiotics has been one of simultaneous institutional success and intellectual bankruptcy. On the one hand, there are now departments, institutes, associations, congresses and journals of semiotics. On the other, semiotics has failed to live up to its promises; indeed, its foundations have been severely undermined" (1995: 7).
} 
semiólogos que han estudiado el mensaje publicitario - Barthes (1964), Durand (1970), Peninou (1976), Feliu (1983), Williamson (1983), Vazquez y Aldea (1991), Eguizabal (1992) - buscaban un método de análisis válido tanto para el texto como para la imagen, centrándose principalmente en dos objetivos: el funcionamiento y lectura de la imagen y la naturaleza de la relación entre el texto del anuncio y la ilustración que normalmente lo acompaña.

Sperber y Wilson consideran que el enfoque semiótico de la comunicación es una generalización del modelo del código de la comunicación verbal aplicado a todas las formas de comunicación: "Todorov (1977) dates it back to Augustine, who approached the study of grammar, logic, rhetoric and hermeneutics within the unifying framework of a theory of signs" (1995: 6). Al igual que el esquema de Lyons, el modelo semióticoinformacional (véase figura 3) hace hincapié en la importancia de la significación dentro del proceso comunicativo:

The linearity of the transmission is tied in with the way the semantic factors work, which are introduced by means of the concept of code. In other words, the acceptance of communication as transfer of information leads on to the acceptance of transformation of one system into another. The code guarantees the possibility of this transformation. (Wolf 1987: 139)

La enorme distancia que puede existir entre el mensaje emitido como significante - portador de un determinado significado - y el mensaje recibido como significado se explica, en el modelo semiótico, mediante el papel desempeñado por los diferentes códigos y subcódigos. El emisor formula un mensaje sobre la base de un determinado código que, a su vez, es descodificado por el receptor sobre la base de su propio código. El principal objetivo del semiólogo es desenmascarar los sistemas de signos que existen en todo proceso comunicativo.

El modelo-semiótico informacional describe los mecanismos comunes que existen entre la comunicación de masas y la comunicación personal. Para un análisis específico de la comunicación de masas, Eco-Fabbri (1978: 570) añade las siguientes precisiones: 
A - Los destinatarios no reciben mensajes particulares reconocibles sino conjuntos textuales.

B - Los destinatarios no comparan los mensajes con códigos reconocibles como tales sino con conjuntos de prácticas textuales. Es decir, aunque desconozcan el funcionamiento de los códigos específicos, entienden el mensaje (noticia, reportaje, anuncio, etc.) ya que reconocen la fórmula que utilizan.

$\mathrm{C}$ - Los destinatarios no reciben nunca un único mensaje, reciben muchos tanto en sentido sincrónico como diacrónico.

\section{2. - EL MODELO DEL CÓDIGO EN LA COMUNICACIÓN PUBLICITARIA}

A la hora de explicar la comunicación publicitaria, los estudiosos de la publicidad recurren a modelos muy similares a los anteriormente expuestos. Después de haber dedicado el primer capítulo de su libro The language of advertising a reflexionar sobre qué es la publicidad, Vestergaard y Schroder (1985) presentan la situación comunicativa en la que se lleva a cabo el proceso publicitario. Comienzan indicando sus tres principales particularidades:

1. - El mensaje publicitario tiende a utilizar la comunicación verbal combinada con comunicación no verbal: principalmente imágenes.

2. - La publicidad se engloba en lo que se considera comunicación pública: el emisor no conoce a los receptores de su mensaje.

3. - El mensaje publicitario es unidireccional y no bidireccional. El receptor no puede responder - al menos de inmediato - al emisor que le ha enviado el mensaje.

Posteriormente recurren al esquema de Leech, cuyos componentes no difieren de los modelos que hemos visto anteriormente: 


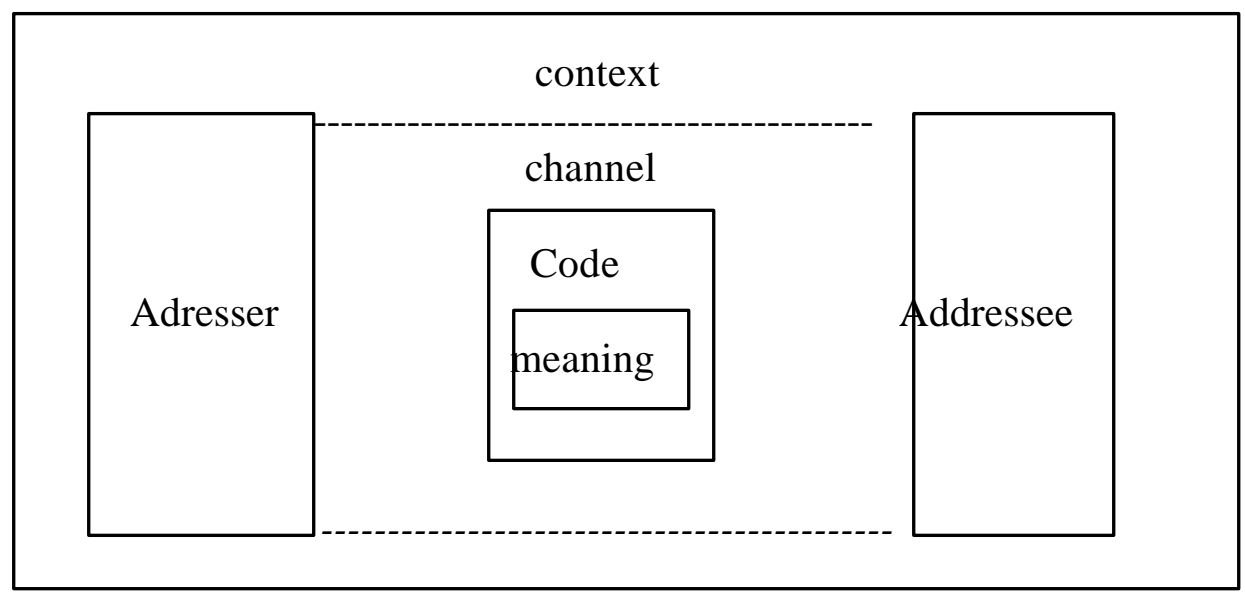

Leech (1974: 49)

Figura 4

Vestergaard y Schroder se limitan a definir los elementos que intervienen en este particular medio de comunicación:

In the case of advertising the relation between this abstract, general communication model and the actual situation is fairly obvious: the addresser is the advertiser, and the addressee is the reader, the meaning transmitted is about the product (more specifically, an attempt to make the reader buy the product), the code (in the case of press advertisements) is language and some sort of visual code, the channel consists of printed publications, and the context will include such features as the reader's total situation (does he have the product already? Can he afford it?, etc.), the publication in which the advertisement appears, and last but not least the knowledge that the text is an advert. (1985: 16)

Los modelos propuestos para estudiar la comunicación publicitaria parten de los supuestos expresados en el modelo del código a los que se les añaden ciertas particularidades. Así, definen la situación específica en la que se produce la comunicación publicitaria de la siguiente manera: un grupo cualificado de emisores ${ }^{92}$ - cada uno de los

\footnotetext{
${ }^{92}$ Cook resalta lo siguiente: "With ads there is the further complication that there is no single sender, because ads are not the creation of an individual. There are, rather, many strata of senders, ranging from the manufacturer through the agency and its creative department, to the actors and the camera crews who produce it" (1992: 6).
} 
cuales tiene una función perfectamente definida - crea un mensaje, normalmente compuesto de texto e imagen, que les ha sido encargado por una empresa determinada con el objetivo de persuadir a un grupo de receptores sobre las bondades de un producto o servicio. La empresa tiene claro su propósito, aunque no la manera de llevarlo a cabo. Por lo tanto recurre a una agencia publicitaria que mediante el uso de diversos códigos - tanto lingüísticos como paralingüísticos ${ }^{93}$ - construye un mensaje que será enviado a los receptores a través de uno o varios medios de comunicación de masas. El receptor reconoce que se encuentra ante un anuncio y lo descodifica y si el mensaje cumple su objetivo modifica su percepción del producto. La agencia publicitaria recibirá información relativa al número de receptores que han sido persuadidos por el mensaje: si este número se considera suficiente, el publicista seguirá enviando mensajes similares mientras que si se considera insuficiente modificará una o varias características del mensaje emitido.

Eguizabal añade una precisión más relativa al papel social de la comunicación publicitaria afirmando que debido a la asimetría de los papeles comunicativos desempeñados por el emisor y el receptor, en la estrategia del emisor se insertan los conocimientos que posee sobre el destinatario, conocimientos que no han sido adquiridos de manera intuitiva sino por medio de investigaciones sobre los tipos de público, estudios de audiencias, investigaciones de mercados, etc. De esta manera, la codificación de los mensajes publicitarios se intentará ajustar a la descodificación que van a llevar a cabo los individuos a los que se dirige el anuncio. Todo ello se desarrolla dentro de los diversos elementos del sistema social que intervienen en la comunicación publicitaria, representados por Eguizabal en el siguiente gráfico:

\footnotetext{
${ }^{93}$ Cook denomina paralenguaje al significado derivado de los colores, distribuciones de los objetos, posturas de los personajes, etc. Eguizabal (1992: 151) distingue estos siete códigos en todo anuncio publicitario en prensa: cromático, tipográfico, fotográfico, morfológico, gestual y posicional, sociocultural y verbal.
} 


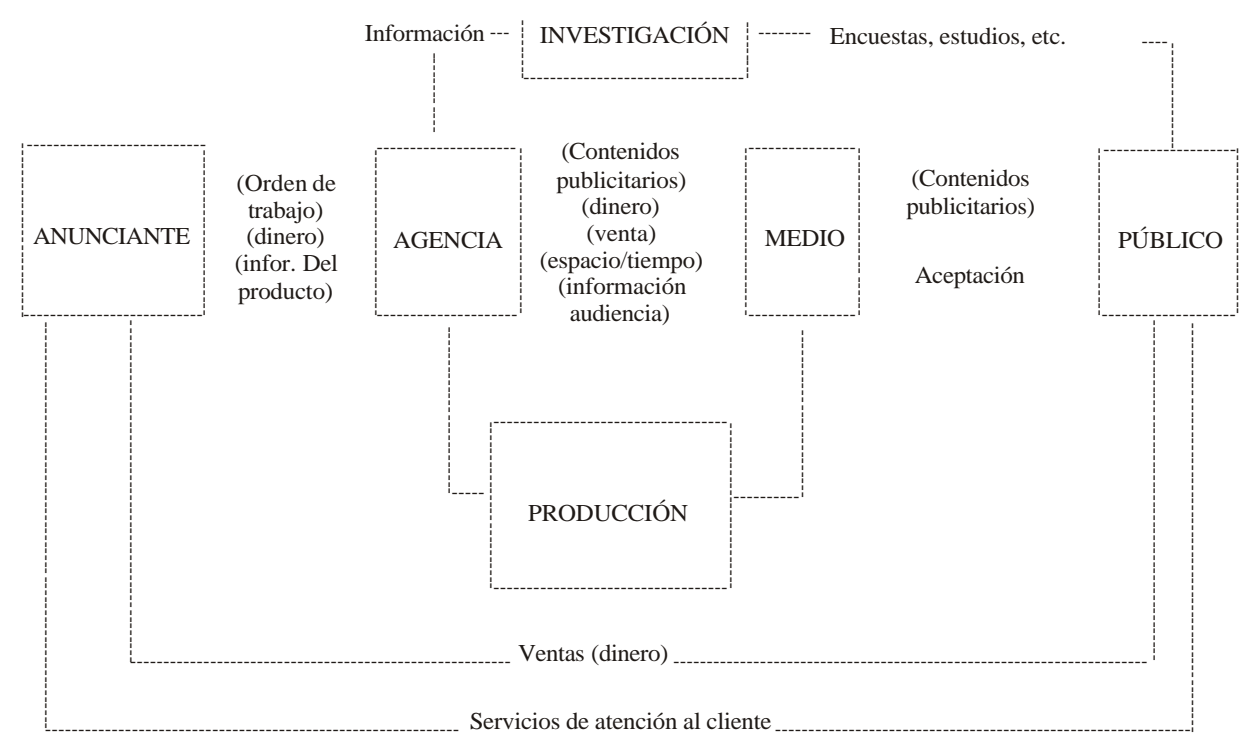

\section{3. - ALGUNOS PROBLEMAS DEL MODELO DEL CÓDIGO}

Desde una perspectiva lingüística, el modelo del código plantea diferentes problemas de difícil solución. El primero de ellos reside en el supuesto, ya mencionado por Richards (1985: 256) de que emisor y receptor no sólo comparten un idioma común sino que también comparten un mismo contexto. Esta idea se conoce como la hipótesis del conocimiento mutuo y supone que cada elemento de información contextual en una expresión sea conocido de forma mutua por el emisor y el receptor. Parece evidente que determinar los límites de ese conocimiento mutuo implicaría un esfuerzo mucho mayor que el que necesitamos para emitir y comprender un enunciado. Según el modelo del código los pensamientos que el emisor transmite se reproducen exactamente en la mente del receptor. El uso cotidiano del lenguaje parece ir en contra de esta afirmación ya que, como Sperber y Wilson afirman:

The most cursory examination of ordinary conversation reveals that in the case of implicit import, figurative interpretation and stylistic effects, such reproduction [in the hearer of the thoughts the speaker intended to convey] is rarely intended or achieved. (Sperber y Wilson 1987: 7) 
La existencia de contextos distintos es una de las causas más comunes que imposibilita una comunicación satisfactoria. En mi círculo de amigos, una de las preguntas más recurrentes durante los días anteriores al jueves 26 de noviembre de 1998 era la siguiente:

(1) - ¿ Irás a Vigo el jueves ?

Los simpatizantes del Celta de Vigo no tenían ningún problema a la hora de interpretar este enunciado ya que en su contexto cognitivo figuraba el siguiente supuesto:

(2) - El jueves, el Celta juega contra el Liverpool en Vigo un partido muy importante.

Consecuentemente inferirán lo siguiente:

(3) - Me preguntan si el jueves voy al estadio de fútbol a presenciar el partido del Celta.

Sin embargo, si formulamos la anterior pregunta a una persona que desconoce lo que ocurre el jueves en Vigo no se producirá una comunicación satisfactoria debido a que no encontrará sentido a la pregunta y, desorientado, intentará buscarle un significado indagando sobre el motivo de su supuesta vinculación con la ciudad de Vigo. Este ejemplo ilustra un problema ignorado por los modelos del código: la existencia de contextos diferentes puede dificultar la comunicación.

Otro de los problemas que plantea el modelo del código está relacionado con la posibilidad que tenemos los hablantes de expresar una idea de muy distintas maneras y utilizando en todas ellas el mismo código: nuestro idioma. Podemos escoger entre comunicar una idea utilizando una expresión metafórica o recurrir a una expresión más literal. Por ejemplo, podemos escoger entre el enunciado Juan es un pedazo de pan y Juan es mиy bondadoso. Ambos enunciados tienen un significado similar, pero al parafrasear el enunciado metafórico observamos que éste pierde parte de su efecto - 
familiaridad, afectividad, fiabilidad, etc. - evidenciando así que se comunica mucho más de lo que en realidad se codifica ${ }^{94}$.

Corrales considera que la explicación de la comunicación humana mediante la teoría del código es laboriosa y antieconómica:

La explicación por medio de la teoría del código es excesivamente laboriosa y antieconómica pues supone, en primer lugar, la multiplicación innecesaria de "códigos" y, en segundo lugar, que el código debe ser aprendido antes de que podamos llegar a interpretar algo, lo cual es plausible en la adquisición, pero no en los procesos de interpretación. (1996: 6)

Partiendo de la consideración del texto y del discurso como unidades comunicativas, el análisis del discurso ha puesto de relieve que el modelo del código presenta múltiples carencias. Ello ha abierto nuevas perspectivas en todos los campos de la comunicación humana como, por ejemplo, en el ámbito de la crítica literaria. En su libro Feminist Stylistics, Mills busca un modelo comunicativo que le sirva de base para analizar todo tipo de textos - tanto literarios como de uso común - con el objetivo de llegar a unas conclusiones globales sobre nuestras preconcepciones a la hora de enfrentarnos a ellos. También se interesa por explorar las relaciones de los textos con su contexto y sus destinatarios, ya que considera que es en este dominio donde se esconden la mayor parte de las representaciones de las diferencias entre el género femenino y el masculino. Antes de presentar el modelo comunicativo, que ella denomina a feminist model of text (Mills 1995: 2), lleva a cabo una crítica del modelo del código que, al igual que ocurrre en el estudio de los medios de comunicación de masas, también resulta ser uno de los más utilizados en el campo de la crítica literaria:

Many of the stylistic analyses which have been undertaken have used a textimmanent model of meaning; that is, they have assumed that what the critic "finds" in the text is located in the text itself, rather than perhaps being more the result of a negotiation between the reader and the text. In a similar way, traditional stylicians rarely discuss the

\footnotetext{
${ }^{94}$ En el artículo "Retórica y Pertinencia" (1990), Sperber y Wilson explican, siguiendo la teoría de la relevancia, cómo se comunican y procesan efectos poéticos como la metáfora o la ironía.
} 
model of language that they are drawing upon in order to come to their analysis of the text. (Mills 1995: 26)

Por el interés que tiene para este trabajo, pasamos a enumerar, de forma resumida, diferentes premisas existentes en el modelo del código cuya inoperancia Mills pone de manifiesto, algo que también ha sido sobradamente demostrado en el análisis del discurso:

1 - El pensamiento precede a la producción del habla y de alguna manera está separado del lenguaje y existe independientemente de éste.

2 - El mensaje que el emisor codifica por medio del lenguaje es exactamente igual al mensaje que el receptor descodifica: si no existen ruidos no hay posibilidad de malentendidos ni impedimentos para la comunicación.

3 - El modo usual de comunicación se lleva a cabo entre dos participantes, de los cuales uno se dedica a hablar y el otro se limita a escuchar.

4 - El emisor posee un control total del lenguaje y puede expresar todo lo que desee: no tiene limitaciones o "presiones" del lenguaje a la hora de manifestar sus ideas. El receptor, esencialmente pasivo, se limita a descodificar el mensaje y logra un entendimiento perfecto de la información transmitida.

Los puntos anteriores plantean algunos de los numerosos problemas que inevitablemente surgen a la hora de aplicar el modelo del código a situaciones comunicativas reales. Podemos destacar, entre muchos otros, el que se refiere a la función del receptor al que se le asigna un papel esencialmente pasivo. Sabemos que el receptor, cuando recibe un texto, intenta participar de forma activa en el proceso comunicativo, interpretando, buscando inferencias, construyendo hipótesis que bien confirmará o rechazará durante el transcurso del intercambio comunicativo. Del mismo modo, el emisor puede controlar las señales que está emitiendo y utilizar el feedback recibido para modificar parte del mensaje - bien en el fondo o en la forma - durante el proceso de transmisión. Ello nos lleva a considerar que los procesos de comunicación son de una naturaleza más interactiva que lo sugerido por el propio modelo del código. 
Tampoco parece razonable pensar que todo emisor posee un control total del código que utiliza para comunicarse. Cada persona tiene un grado de conocimiento de su idioma distinto que le hará más fácil - o más difícil - poder comunicarse de manera precisa con los demás. Los mensajes que se transmiten escapan a menudo del control del emisor debido, entre otros factores, a la multiplicidad de significados o intenciones que se pueden deducir de un enunciado. En toda comunicación hay un grado tolerable de indeterminación que el receptor considera como normal.

\section{4. - ANÁLISIS DEL MODELO SEMIÓTICO DE BARTHES APLICADO A UN ANUNCIO PUBLICITARIO}

Antes de presentar el modelo comunicativo que ofrecemos como alternativa para solucionar las deficiencias existentes en el modelo del código, vamos a llevar a cabo una revisión del análisis semiótico de un texto publicitario. El anuncio que reproducimos a continuación fue utilizado por Roland Barthes en un artículo titulado "Retórica de la imagen" (1970) para mostrar cómo se puede aplicar el modelo semiótico al estudio de los mensajes publicitarios y con el paso del tiempo se ha convertido en un clásico dentro de la semiología de la imagen ${ }^{95}$. Recordemos que los semiólogos parten de la siguiente premisa: la comunicación se produce por medio de la codificación y la descodificación de un mensaje y la condición necesaria y suficiente para que ésta se realice con éxito es la existencia de un código común entre el emisor y el destinatario. Así, Barthes distingue tres mensajes diferentes en el anuncio de pastas Panzani (véase figura 5):

- El mensaje lingüístico

- El mensaje icónico codificado

- El mensaje icónico no codificado

En el mensaje lingüístico diferencia a su vez dos tipos de mensajes; de denotación y de connotación:

\footnotetext{
${ }^{95}$ En Mythologies (1957) Barthes recopila ciertos artículos periodísticos donde ya aparece el germen de su concepción de la función de los anuncios publicitarios: la creación de un universo de símbolos de carácter social que facilitan la promoción de los productos publicitados.
} 


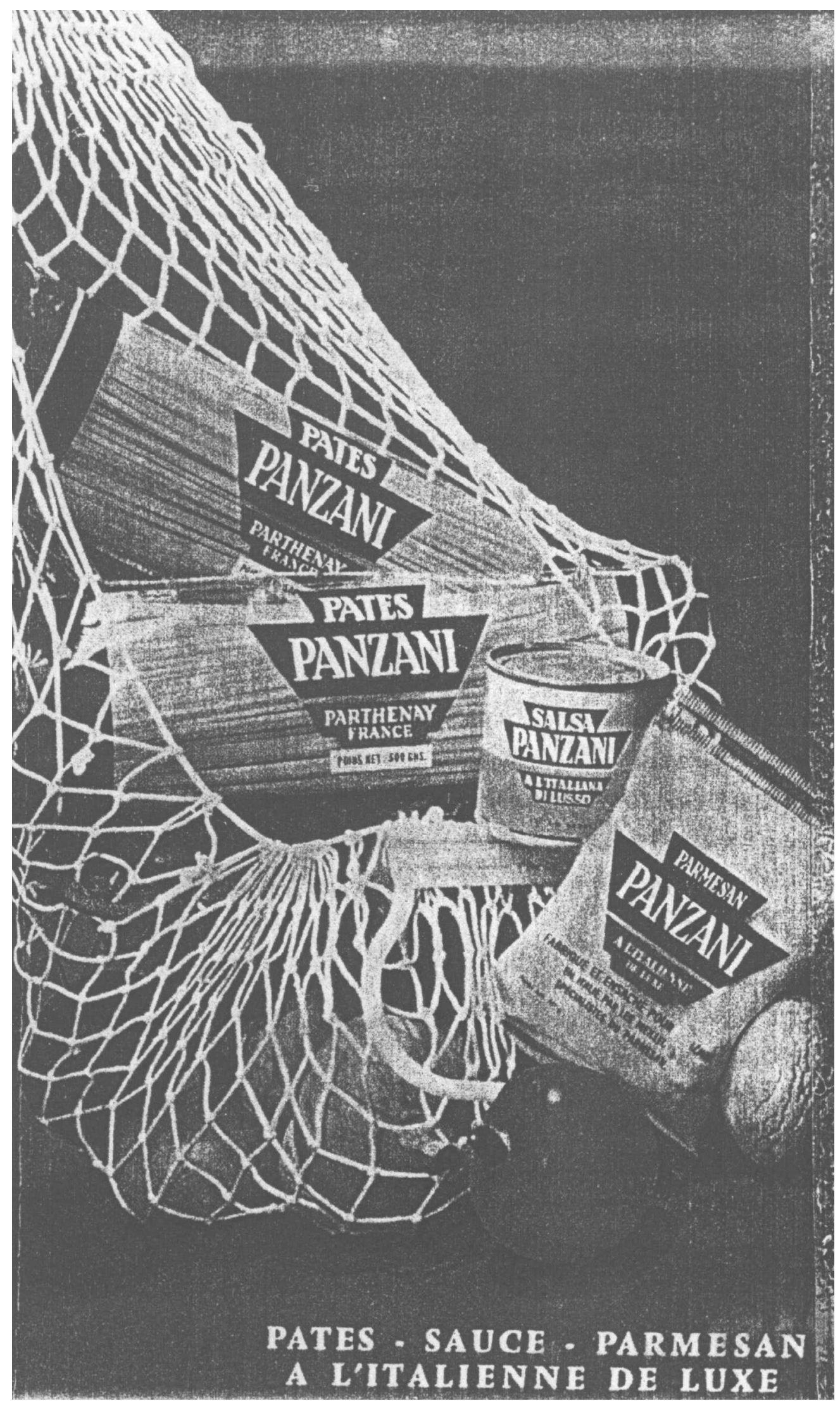


... el signo Panzani no transmite solamente el nombre de la firma, sino también, por su asonancia, un significado suplementario, que es, si se quiere, "la italianidad"; el mensaje lingüístico es por lo tanto doble (al menos en esta imagen): de denotación y de connotación.” (Barthes 1970: 128)

Dejando a un lado el mensaje lingüístico - compuesto por el texto que aparece en el pié de página y por las etiquetas de los productos representados - nos encontramos con la imagen en la que también se definen dos categorías equivalentes a la distinción anteriormente expuesta de connotación y denotación. La primera categoría se caracteriza como codificada, simbólica y cultural mientras que la segunda se considera no codificada, literal y únicamente dependiente de nuestra capacidad de percepción.

En la imagen del anuncio Barthes diferencia en la primera categoría, mensaje icónico codificado, cuatro signos de carácter connotativo que forman un conjunto coherente dentro del anuncio y que constituyen, lo que denomina, mensaje de naturaleza simbólica:

- Representar la vuelta del mercado implica dos valores: la frescura de los productos y la preparación casera a la que están destinados.

- La combinación tricolor (amarillo, rojo y verde) utilizada en la imagen del anuncio "significa" Italia, o más bien la italianidad.

- La representación de diferentes productos Panzani transmite la idea de un servicio culinario total.

- La composición, que evoca el recuerdo de muchas representaciones pictóricas de alimentos, remite a un significado estético: es la "naturaleza muerta" o, como mejor lo expresa la lengua inglesa, el still life.

Respecto a la segunda categoría que distingue en la imagen, Barthes afirma que el mensaje literal es un mensaje sin código, y está formado por los diferentes objetos fotografiados. Este mensaje icónico no codificado consiste en la reproducción analógica de objetos reales, con los que los signos están en relación no arbitraria; el denominado mensaje perceptivo o imagen denotada: 
Para leer este último (o este primer) nivel de la imagen no necesitamos otro saber que el relacionado con nuestra percepción: éste no es nulo, pues es preciso saber qué es una imagen (los niños no lo saben antes de los cuatro años) y qué es un tomate, una red, un paquete de fideos: se trata, sin embargo de un saber casi antropológico. Este mensaje corresponde de algún modo a la letra de la imagen, y lo llamaremos mensaje literal por oposición al mensaje precedente, que es un mensaje "simbólico". (1970: 130)

La primera objeción que encontramos en este análisis es la cuantificación de los signos de connotación de la imagen ya que ésta parece obedecer a criterios completamente subjetivos. Como hemos visto, Barthes distingue cuatro signos pero ¿por qué se agrupa la frescura de los productos con la preparación doméstica en un sólo signo? Quizás nosotros, desde nuestra perspectiva actual, podríamos aportar una nueva categopría: el tomate, la cebolla, la seta y los ajos no sólo connotan frescura sino también una alimentación sana y natural. También podríamos añadir otro nuevo signo de naturaleza simbólica ${ }^{96}$ : la red puede connotar abundancia, haciendo referencia a la escena bíblica de la pesca milagrosa.

Un segundo inconveniente de este análisis se refiere al abuso de la capacidad interpretativa del estudioso del anuncio publicitario, que contrasta con la falta de consideración a la que se someten los problemas de carácter práctico: si en este anuncio se utilizase una bolsa cerrada sería imposible ver, en la disposición de la ilustración, parte de su contenido. Puede que la agencia publicitaria hubiese recibido un briefing en el que se le inste a hacer una campaña para toda la gama de productos Panzani y no anuncios individualizados. Cabe también la posibilidad de que la empresa hubiera solicitado hacer un anuncio de bajo presupuesto o que el publicista dispusiera de un corto período de tiempo para su elaboración. Ambos factores pudieron haber inclinado al creativo publicitario a optar por presentar el envase del producto: la técnica más rudimentaria y tradicional.

En el anterior análisis existen además otros problemas de una naturaleza más formal: la psicología cognitiva considera que la distinción entre denotación y connotación ofrece dudas tanto en lo relativo al componente lingüístico como al de la imagen,

\footnotetext{
${ }^{96}$ Barthes menciona este signo en su análisis pero no es considerado como uno de los cuatro signos de connotación de la imagen.
} 
asumiendo que la percepción humana no se lleva a cabo independientemente del conocimiento cultural:

As Fodor (1983) points out, a distinction between "central thought processes" and "perceptual" processes is assumed in current cognitive psychology. Perceptual systems are said to transform information from sensory representations into conceptual representations. The information received by such input systems, however, underdetermines the information derived from them by the central thought processes. In other words, the central thought processes integrate information derived from the senses with information stored in memory to determine what is actually perceived. Thus, even the processing of information derived from the senses is affected by cultural knowledge. (Tanaka 1994: 2)

Si nuestra capacidad de percepción está condicionada por complejas operaciones a nivel cerebral (lo que Fodor denomina central thought processes) resulta imposible establecer una distinción clara entre los conceptos de denotación y connotación ya que el conocimiento cultural de cada individuo afecta de manera definitoria a todas sus percepciones.

La función que Barthes atribuye al mensaje lingüístico de los anuncios publicitarios también plantea ciertos problemas. Después de destacar su omnipresencia acompañando a las imágenes que aparecen en los medios de comunicación de masas, afirma que el mensaje lingüístico tiene dos funciones: el anclaje en las imágenes fijas (publicidad en prensa, fotografía, etc.) y el relevo en las imágenes continuas (publicidad en televisión, cine, historietas, etc.). En publicidad la función de anclaje se considera necesaria para conseguir fijar el significado que se quiere transmitir con la imagen:

... toda imagen es polisémica; implica, subyacente a sus significantes, una cadena flotante de significados, entre los cuales el lector puede elegir algunos e ignorar los otros. La polisemia da lugar a una interrogación sobre el sentido, que aparece siempre como una disfunción, aun cuando la sociedad recupere esta disfunción bajo forma de juego trágico ... o poético ... La leyenda me ayuda a elegir el nivel de percepción adecuado; me permite acomodar no sólo mi mirada sino también mi intelección. (Barthes 1970: 132) 
Esta afirmación choca con las funciones que diferentes estudiosos del lenguaje de la publicidad atribuyen al mensaje lingüístico en relación a la imagen. Además de la función de anclaje, Ferraz Martínez (1993: 22) distingue otras cuatro funciones en el mensaje lingüístico:

- Función de intriga: existen campañas de lanzamiento en las que, para captar la atención del cliente potencial, se elaboran anuncios con enunciados enigmáticos que en fases posteriores de la campaña cobran sentido pleno.

- Función complementaria: el texto aporta nuevos significados que no están presentes en la imagen con diversas finalidades: instrumental o denotativa, connotativa, narrativa, etc.

- Función identificadora: el texto se reduce a darnos el nombre de la marca del producto.

- Función de transgresión del código esperado: se recurre a lenguas diferentes de la esperada por el receptor.

Feliu García va más allá y considera una simplificación cualquier intento de atribuir unas funciones determinadas al texto lingüístico en publicidad: "Las relaciones entre texto e imagen son de una complejidad harto difícil de reducir, como determinados autores pretenden" (1984: 160).

Siguiendo con la revisión del análisis de Barthes debemos apuntar que tampoco parece claro el hecho de que el destinatario de una imagen se encuentre con "una cadena flotante de significados, entre los cuales puede elegir alguno e ignorar otros" ya que, según la teoría de la relevancia, este proceso de selección no se produce de manera aleatoria sino que obedece a criterios de máxima relevancia. La cognición humana ha desarrollado la capacidad de combinar cualquier nueva información con la información ya existente en su cerebro con el objetivo de reducir el esfuerzo de procesamiento y maximizar los posibles efectos contextuales atendiendo a criterios que examinaremos en próximos apartados ${ }^{97}$.

\footnotetext{
${ }^{97}$ Para un análisis de la relación entre la teoría de la relevancia y los central thought processes (Fodor 1983) véase el artículo de Sperber y Wilson "Fodor's Frame Problem and Relevance Theory" (1996).
} 
Añadiremos una última consideración: si el mensaje lingüístico tiene la función de delimitar el significado polisémico de la imagen - y, según Barthes, la polisemia siempre es percibida como una disfunción - ¿Cómo podemos explicar la frecuente utilización de juegos de palabras, rimas, paradojas, tautologías, etc. en los anuncios publicitarios? Tanaka (1994: 3) afirma que su principal atractivo reside en que consiguen captar la atención del receptor implicándolo en la resolución de las distintas interpretaciones que ofrecen. Además, los mensajes lingüísticos cotidianos también pueden ser polisémicos: es una idealización pensar que en el proceso de codificación-descodificación no existe la ambigüedad ya que en éste influyen factores como el contexto, el conocimiento previo del emisor, la interacción, etc. ${ }^{98}$ Consecuentemente, no podemos afirmar que el mensaje lingüístico únicamente tenga una función de anclaje respecto a la imagen publicitaria.

Como podemos observar, el análisis semiótico deja abiertas muchos interrogantes que mayormente están relacionadas con el modelo comunicativo que propone. En este apartado hemos llevado a cabo una crítica al análisis de un anuncio seleccionado por el propio Barthes pero para que su teoría tuviera validez debería de poder ser aplicada a todo tipo de anuncios publicitarios. Por ejemplo, Tanaka (1994: 4) considera que es imposible buscar connotaciones en los anuncios de la polémica campaña de Benetton que mostraba, entre otras cosas, un enfermo de sida en su lecho de muerte, una víctima de la mafia, una silla eléctrica, un coche en llamas,... ya que no parece existir una conexión clara entre estos anuncios y la ropa que publicitan. También menciona una de las campañas de cigarrillos Silk Cut en la que se llegaba a obviar la marca del producto y el único texto que aparecía era el aviso de las autoridades sanitarias sobre los perjuicios que acarrea fumar. Para hacerse una idea de lo que realmente pretenden estos anuncios debemos hacer algo más que codificar y descodificar sus mensajes. Así, en el siguiente apartado propondremos un modelo comunicativo que complementa el tradicional modelo del código y que nos ayudará a comprender mejor el funcionamiento de los anuncios publicitarios.

\footnotetext{
${ }^{98}$ Como señala Díez Arroyo (1998: 18) existen numerosos estudios sobre la interpretación de oraciones (Altman 1988, Bransford y Johnson 1973, Bresnan 1981) que destacan que el lenguaje natural tiene un alto componente de ambigüedad y su interpretación requiere tomar decisiones sobre la asignación de referentes, desambiguación, etc.
} 


\section{5. - LA COMUNICACIÓN INFERENCIAL}

\subsection{1. - El modelo del código frente al modelo inferencial}

En los anteriores apartados hemos comprobado cómo el principal problema que presentan los análisis basados en el modelo del código reside en la aplicación de una teoría de la comunicación que no acepta que la recuperación del significado de un mensaje por parte del receptor consiste en algo más que descodificar signos. En "The Conduit Metaphor" (1979) Michael Reddy pone de manifiesto el error que supone considerar la comunicación lingüística exclusivamente bajo el planteamiento del código. En consonancia con esta idea surgen diversas teorías que estudian la comunicación humana bajo nuevas perspectivas. Entre ellas se encuentra la teoría de la relevancia que, por las razones que iremos analizando a continuación, constituye el marco teórico que aplicaremos en nuestro trabajo.

Sperber y Wilson (1995) comienzan el primer capítulo del libro en el que exponen su teoría de la relevancia preguntándose cómo se comunican entre sí los seres humanos. Como respuesta a la anterior pregunta sostienen que los humanos nos comunicamos utilizando dos modalidades de comunicación totalmente diferentes, aunque no incompatibles: la comunicación codificada y la comunicación ostensivo-inferencial. La comunicación inferencial pertenece principalmente al ámbito de la pragmática y aquí entran en juego factores como la información contextual que no es de naturaleza lingüística, la intencionalidad del emisor, las destrezas inferenciales del destinatario, etc.

La teoría de la relevancia tiene como principal objetivo explicar cómo se produce la transición entre lo que el emisor de un mensaje dice literalmente y la interpretación pragmática que el receptor extrae, mostrando, a su vez, la incapacidad del modelo del código para aclarar este proceso. Consideremos el siguiente enunciado:

(1) - Él es bastante pesado 
Según Sperber y Wilson (1995), Blakemore (1988) o Byrne (1992), entre otros, para llegar a captar la intención del emisor de (1), además de conocer el código que está empleando - la lengua española - debemos llevar a cabo las siguientes operaciones:

- Asignar un referente al pronombre personal "él". La gramática nos ayuda afirmando que debe ser masculino y que ha sido mencionado con anterioridad, pero esta información no es suficiente para identificar de manera precisa al sujeto de la indeterminación referencial.

- Resolver la indeterminación semántica que nos plantea la palabra "pesado": ser demasiado insistente o pesar muchos quilos.

- Averiguar de acuerdo a qué criterios es pesado ya que el término "bastante" no posee un significado claramente definido.

- Considerar el grado de tolerancia del hablante con los pesados: puede tratarse de una persona paciente $\mathrm{o}$, al contrario, fácilmente alterable. El enunciado será interpretado de manera distinta dependiendo de nuestro propio conocimiento del emisor.

Además de las anteriores observaciones, imprescindibles para que se pueda llevar a cabo una correcta comunicación, Sperber y Wilson plantean un segundo problema que el modelo del código ignora: los actos de habla que realizan los enunciados o la fuerza ilocutiva que poseen ya que los enunciados no sólo se utilizan para transmitir pensamientos sino que también manifiestan la actitud del hablante frente a la idea expresada. Veamos el siguiente ejemplo:

(2) - ¿Sabes qué hora es?

La interpretación de (2) será diferente dependiendo de la actitud del hablante que la pronuncia: en el caso de un hablante desprovisto de reloj su propósito puede limitarse a averiguar la hora. En un contexto diferente - imaginemos al mismo hablante en una fiesta acompañado por una persona desprovista de reloj - su actitud al emitir el anterior enunciado puede ser distinta: informar al oyente de que es demasiado tarde y 
posiblemente sugerirle implícitamente ${ }^{99}$ que es hora de irse. Cuando ese mismo hablante llega a su casa puede escuchar la misma frase. Esta vez en boca de su marido o mujer cuya actitud más probable sea la de reprobación por haber llegado demasiado tarde.

Con los anteriores ejemplos podemos comprobar que para llevar a cabo una interpretación completa de los enunciados debemos tener en cuenta tanto factores lingüísticos, fonéticos, gramaticales y semánticos principalmente, como no linguísticos: básicamente el contexto en el que se pronuncian. Aquí debemos establecer una distinción entre el concepto de oración - estudiado por la gramática - y el de enunciado - principal punto de interés de la pragmática:

An utterance has a variety of properties, both linguistic and non-linguistic. It may contain the word "shoe", or a reflexive pronoun, or a trisyllabic adjective; it may be spoken on top of a bus, by someone with a heavy cold, addressing a close friend. Generative grammars abstract out the purely linguistic properties of utterances and describe a common linguistic structure, the sentence, shared by a variety of utterances which differ only on their non-linguistic properties. By definition, the semantic representation of a sentence, as assigned to it by a generative grammar, can take no account of such non-linguistic properties as, for example, the time and place of utterance, the identity of the speaker, the speaker's intentions, and so on. (Sperber and Wilson 1995: 9)

Hemos comprobado que las frases (1) y (2) dan lugar a diferentes enunciados dependiendo de factores contextuales tales como la asignación de referentes, la situación comunicativa, la actitud del hablante, sus intenciones, etc. La pragmática no puede ignorar el proceso que ocurre en la mente del oyente y que le lleva a realizar una elección concreta entre todas las posibilidades que se le ofrecen para conseguir una comprensión adecuada. Según la teoría de la relevancia, la distancia que existe entre el significado linguístico codificado de una frase y lo que realmente se comunica no se llena por medio

\footnotetext{
${ }^{99}$ Sperber y Wilson establecen una distinción entre los enunciados que expresan un pensamiento de forma explícita y los que lo hacen de forma implícita: "Whereas a thought that is explicitly expressed must be in some kind of correspondence to the semantic representation of the sentence uttered, those that are implicitly conveyed are under no such constraint" (1995: 11). Así vemos cómo los contenidos implícitos son incompatibles con la idea de que comunicarse únicamente consiste en codificar y descodificar información.
} 
del proceso de codificación-descodificación sino que para ello se utilizan las inferencias $^{100}$ :

An inferential process starts from a set of premises and results in a set of conclusions which follow logically from, or are at least warranted by, the premises. A decoding process starts from a signal and results in the recovery of a message which is associated to the signal by an underlying code. (Sperber and Wilson 1995: 13)

Partiendo del supuesto de que el modelo del código establece el marco general para una teoría de la comunicación, podría argumentarse que en la interpretación de los enunciados también se llevan a cabo procesos inferenciales cuyo principal objetivo es economizar esfuerzo. Las implicaturas podrían considerarse como un complemento al modelo del código ya que son inferidas por el oyente apoyándose en la información que puede descodificar, en la información contextual y en las expectativas sobre la actitud del emisor. Sperber y Wilson consideran que para justificar este planteamiento habría que demostrar que la interpretación de toda unidad comunicativa dentro de su contexto se puede explicar añadiendo un nivel pragmático adicional de descodificación al nivel lingüístico:

Much recent work in pragmatics has assumed, largely without question, that this can be done. Pragmatics has been treated, on the analogy to phonology, syntax and semantics, as a code-like mental device, underlying a distinct level of linguistic ability. It is widely accepted that there are rules of pragmatic interpretation much as there are rules of semantic interpretation, and that these rules form a system which is a supplement to a grammar as traditionally understood. (Sperber and Wilson 1995: 12)

Aunque reconocen que este modelo es válido para algunos casos concretos consideran que no puede elevarse a la categoría de teoría general:

To substantiate the code model of verbal communication, it would have to be shown that every case of reference assignment can be dealt with by rules which

\footnotetext{
${ }^{100}$ Escandell las define de la siguiente manera: "La inferencia es el proceso por el cual se otorga validez a un supuesto sobre la base de la validez de otro supuesto" (Escandell 1993: 131).
} 
automatically integrate properties of the context with semantic properties of the utterance. It would also have to be shown that disambiguation, the recovery of propositional attitudes, figurative interpretations and implicit import can be handled along similar lines. Nothing approaching such a demonstration has ever been given. (Sperber and Wilson 1995: 12)

Según el modelo inferencial, la comunicación se consigue cuando el emisor proporciona al receptor ciertos indicios sobre sus intenciones y este último infiere, a partir de los indicios que recibe, las intenciones del emisor. La comprensión inferencial es un proceso no demostrativo. Es decir, la interpretación que se da a una frase no sale directamente de su contenido y esa interpretación tiene un mayor o menor grado de posibilidades de ser correcta, aunque no se pueda garantizar que realmente lo sea. Veamos el siguiente ejemplo:

(3)A - ¿Vendrás al cine esta noche?

B - Estoy un poco cansado.

Muy probablemente, el oyente de 3B añadirá la siguiente premisa (a) al contexto e interpretará (4):

(a) - A una persona cansada no le apetece salir de su casa para ir al cine

4 - No iré al cine

Sin embargo, no podemos deducir (4) del contenido de (3B) sin añadirle la premisa que aparece en (a). Es más, si sustituimos (a) por (b) - imaginemos que el emisor del enunciado está preparando unas oposiciones y acostumbra a estudiar por la noche - podemos incluso llegar a una interpretación opuesta a la anterior (5):

(b) - Una persona cansada de estudiar necesita ir al cine para relajarse.

(5) - Irá al cine esta noche. 
Ni la gramática tradicional ni la semiótica con su teoría de la comunicación basada en el modelo del código pueden decidir cuál es la interpretación más idónea para (3). Por su parte, Sperber y Wilson consideran que los seres humanos se comunican mediante dos modalidades diferentes utilizadas de manera distinta concediendo una mayor prominencia al modelo ostensivo-inferencial sobre el modelo del código: "Whereas ostensive-inferential communication can be used on its own, and sometimes is, coded communication is only used as a means of strengthening ostensive-inferential communication. This is how language is used in verbal communication" (1995: 63).

\subsection{2. - El modelo ostensivo - inferencial}

La elaboración del modelo ostensivo-inferencial que estudiaremos a continuación parte de las ideas expresadas por Grice en sus famosas William James Lectures. Según Sperber y Wilson, su mayor aportación a la historia de la pragmática consiste en considerar como suficiente la siguiente caracterización de la comunicación humana: la comunicación implica el reconocimiento de una intención ${ }^{101}$. Grice considera que la mayor parte de los enunciados utilizados en una conversación ordinaria no llegan a codificar completamente las ideas que se desean expresar ya que se limitan a proporcionar ciertos indicios que suelen ser suficientes para que el emisor pueda recuperar las ideas que el emisor desea transmitir ${ }^{102}$. Grice destaca que en numerosas ocasiones las capacidades inferenciales de los seres humanos utilizadas para atribuirse intenciones permiten llevar a cabo una comunicación satisfactoria sin el uso de ningún código preestablecido, como veremos a continuación en el ejemplo (6).

Sperber y Wilson proponen la siguiente definición de la comunicación ostensivoinferencial:

\footnotetext{
${ }^{101}$ Por su parte, Byrne valora el trabajo de Grice aludiendo al establecimiento de ciertos principios pragmáticos que ayudan a explicar la comunicación humana: "The value of Grice's work lies not so much from the detail of his analyses as from the general claim that underlies them. Grice has shown that given an adecquate set of pragmatic principles (...) a wide range of what at first sight seem to be arbitrary semantic facts can be seen as consequences of quite general pragmatic constraints" (1992: 17).

${ }^{102}$ Grice define el significado que el emisor quiere transmitir en los siguientes términos: "(S) meant something by $\mathrm{x}^{\prime}$ is roughly equivalent to $(\mathrm{S})$ intended the utterance of $\mathrm{x}$ to produce some contextual effect in an audience by means of the recognition of his intention" (1957: 58).
} 
the communicator produces a stimulus which makes it mutually manifest to communicator and audience that the communicator intends, by means of this stimulus, to make manifest or more manifest to the audience a set of assumptions I. (1995: 63)

La ostensión proporciona dos niveles de información: en primer lugar está la información que el emisor comunica al receptor y en segundo lugar está el hecho de que esa información ha sido señalada intencionalmente. Siempre que una persona produce una conducta ostensiva, atrae de manera intencional una cierta cantidad de atención por medio de un estímulo - verbal o no verbal - con el objetivo de hacer manifiesto al receptor un hecho o un conjunto de hechos.

Escandell (1993: 132) recurre a un ejemplo que puede resultar muy clarificador para diferenciar los dos modelos de comunicación que estamos estudiando. Supongamos que una persona quiere comunicar el hecho de que tiene calor. Si elige el modelo codificación/descodificación emitirá un enunciado como el siguiente:

(6) - Tengo calor

Para que el enunciado sea descifrado sólo se presupone la existencia de un código común entre emisor y receptor. Sin embargo, este mismo individuo puede optar por abanicarse exageradamente con la mano, o desabrocharse visiblemente el cuello de la camisa o subirse las mangas de manera notoria. Muy previsiblemente, el receptor que reciba los anteriores estímulos concluirá que la persona que así actúa tiene calor, produciéndose la comunicación. ${ }^{103}$ Escandell señala que para asegurar el éxito de la comunicación ostensivo-inferencial, el receptor tiene que considerar tres circunstancias:

\footnotetext{
${ }^{103}$ Grice defiende que el reconocimiento de las intenciones del emisor es condición suficiente para caracterizar la comunicación humana. Ello supone la posibilidad de comunicarse sin utilizar un código establecido. Searle admite esta posibilidad aunque resalta que no es factible a la hora de comunicar pensamientos complejos: "Some very simple sorts of illocutionary acts can indeed be performed apart from any use of conventional devices at all, simply by getting the audience to recognise certain of one's intentions in behaving in a certain way (...) One can in certain special circumstances "request" someone to leave the room without employing any conventions, but unless one has a language one cannot request of someone that he, e. g., undertake a research project on the problem of diagnosis and treating mononucleosis in undergraduates in American universities" (1969: 38).
} 
1 - Se trata de un estímulo intencional

2 - Dicho estímulo va dirigido a ella

3 - Es una modificación del entorno hecha conscientemente para atraer su atención sobre algún conjunto de hechos

El enfoque propuesto por el modelo inferencial lleva a redefinir el estudio del proceso comunicativo, distinguiendo entre el significado de una expresión y el significado que el comunicador quiere transmitir al emitir tal expresión. El modelo inferencial considera que el receptor comprende una emisión cuando recupera el significado que el emisor ha querido transmitir:

We are all speakers and hearers. As speakers we intend our hearers to recognise our intention to inform them of some state of affairs. As hearers, we try to recognise what it is that the speaker intends to inform us of. Hearers are interested in the meaning of the sentence uttered only insofar as it provides evidence about what the speaker means. Communication is successful not when the hearers recognise the linguistic meaning of the utterance, but when they infer the speaker's "meaning" from it. (Sperber and Wilson 1995: 65)

\subsection{3. - La teoría de la relevancia y la comunicación}

Dentro de los estudios de carácter pragmático la teoría de la relevancia ha sido el modelo que ha conseguido generar una mayor controversia en los últimos veinte años, dando lugar a la aparición de numerosos artículos científicos tanto a favor como en contra de sus postulados ${ }^{104}$. Como ya hemos adelantado (véase apartado 2.5.1.) el principal objetivo de la teoría de la relevancia consiste en ofrecer un modelo comunicativo que explique cómo se lleva a cabo la transición entre el significado literal de un enunciado y la interpretación pragmática extraída por el receptor.

Antes de exponer la definición de relevancia propuesta por Sperber y Wilson, vamos a presentar un ejemplo de una situación que nos servirá para introducir los conceptos en los que esta teoría se basa. Se trata de planteamientos con un componente 
cognitivo muy fuerte que reflexionan sobre nuestro comportamiento cotidiano como emisores y receptores de información donde, como veremos a continuación, la noción de relevancia juega un papel clave en su concepción general de la cognición humana.

\subsubsection{1. - El entorno cognitivo}

Imaginemos la siguiente situación: un decorador tiene una cita en mi casa para llevar a cabo el estudio de una posible reforma en el salón. Una niña le abre la puerta y le pide que espere un momento en el recibidor. Hay infinidad de cosas que esa persona puede observar - y muy probablemente observe - mientras espera: hay unas zapatillas rosas en el recibidor, la casa huele a comida, la televisión está encendida, se escucha la voz de un adulto hablando en la habitación contigua, etc.

El hombre que acaba de entrar en mi casa puede formarse un sinfín de supuestos ${ }^{105}$ sobre nuestra familia partiendo de las observaciones anteriores: aquí vive una niña pequeña, la familia se dispone a comer, alguien está viendo la televisión, una persona habla por teléfono en una habitación cercana, etc. Este conjunto de supuestos es lo que Sperber y Wilson denominan entorno cognitivo: "a cognitive environment of an individual is a set of facts which are manifest to him" (1995: 39). Consideran a su vez que un hecho es manifiesto para una persona en un contexto determinado "if and only if he is capable at that time of representing it mentally and accepting its representation as true or probably true" (ibid. 39).

Sigamos reflexionando acerca de la situación anteriormente propuesta. El hombre que ha entrado en mi casa no puede prestar atención a todos los elementos que hay en ella. Incluso en un espacio tan limitado como un recibidor, es imposible, además de poco razonable, atender a todo lo que puede ser percibido por los sentidos. ¿Qué criterio seguimos a la hora de seleccionar los elementos a los que prestamos atención? ¿Qué nos lleva a formarnos ciertos supuestos y no otros distintos? La teoría de la relevancia considera que existe una tendencia general a prestar atención a ciertos

\footnotetext{
${ }^{104}$ En el apartado 2.7.1. comentaremos diferentes estudios que ponen en duda ciertos aspectos de la teoría de la relevancia.

${ }^{105}$ Escandell define los supuestos de la siguiente manera: "Un supuesto es cada uno de los pensamientos que un individuo tiene catalogados como representaciones del mundo real. Esto es,
} 
elementos y dejar de lado otros ya que el receptor se guía por unos criterios cognitivos generales que persiguen la máxima relevancia:

Anyone would be much more likely to attend to the ringing of the telephone than the ticking of a clock. And given that they do notice the telephone ringing, anyone would be much more likely to form the assumption that someone is phoning me than the assumption that my telephone works." (Blakemore 1992: 28)

Esta idea constituye el principio cognitivo fundamental de la teoría de la relevancia expresado por Sperber y Wilson en la siguiente máxima: "Human cognition tends to be geared to the maximisation of Relevance."

\subsubsection{2. - Implicaciones contextuales ${ }^{106}$}

Introduzcamos un nuevo elemento en la anterior situación. Después de haber esperado durante varios minutos, el decorador que ha llegado a mi casa comienza a preguntarse si se encuentra en la dirección indicada por su jefe. Como no tiene la posibilidad de contrastar este dato, intenta buscar alguna pista que le ayude a confirmar su correcta ubicación y observa lo siguiente:

(a) - La moqueta que recubre el vestíbulo ha sido puesta recientemente

(b) - En el pasillo hay cajas voluminosas que contienen elementos de decoración para una casa: cuadros, figuras, fotografías, jarrones, etc.

Teniendo en cuenta los supuestos expresados en (a) y (b), el decorador puede deducir (1) lo que le llevará a creer que está en la dirección adecuada.

(1) - La familia que actualmente vive aquí acaba de mudarse y necesita llevar a cabo una reforma en su casa.

representaciones diferentes de las opiniones personales, las creencias, los deseos, etc" (1993: $135)$.

106 En apartados posteriores veremos que las implicaciones contextuales son una clase determinada de efecto contextual. 
Una vez confirmada su correcta ubicación, el decorador comienza a pensar en el trabajo que le será encargado. Con este propósito sigue formulándose los siguientes supuestos:

(c) - La moqueta que recubre el vestíbulo es de color rojo intenso.

(d) - Los cuadros que hay en las cajas del pasillo son de pintores contemporáneos.

(e) - La iluminación del pasillo consiste en varias bombillas halógenas y las paredes están cubiertas con láminas de corcho.

Si combinamos los supuestos (c), (d) y (e) podemos llegar a la siguiente conclusión:

(2) - Esta familia desea una modificación del salón de aire moderno y funcional.

La teoría de la relevancia destaca que la información nueva, o presentada como nueva, se procesa teniendo en cuenta la información pre-existente en nuestra memoria: las personas tendemos a formular ciertos supuestos con la expectativa de poder combinarlos con los supuestos que ya poseemos con el objetivo de derivar un efecto contextual. Los supuestos (1) y (2) son distintos a los anteriores ya que han sido derivados de la combinación de la información que depende del contexto ${ }^{107}$ con los supuestos que son propios de cada uno de nosotros y dependen directamente de nuestra experiencia personal y de nuestros conocimientos previos. Partimos de (a) y (b) y llegamos a una conclusión (1), partimos de (c), (d) y (e) y llegamos a (2). Por el hecho de ser derivadas de un contexto determinado Sperber y Wilson denominan a (1) y (2) implicaciones contextuales, que pueden definirse como las inferencias resultantes de combinar cualquier información nueva con los supuestos que ya poseemos. Éste es el método que los humanos utilizamos para procesar información:

${ }^{107}$ La noción de contexto en la teoría de la relevancia se refiere al conjunto de supuestos utilizados en la interpretación de un enunciado. El contexto no viene predeterminado de antemano sino que es elegido por el destinatario en cada situación determinada. 
In every case the method of proccessing is the same. The hearer supplies specific contextual assumptions and derives specific contextual implications. What varies is not the specificity of the assumptions and conclusions derived, or the formality of the reasoning processes involved, but simply the amount of foreknowledge the speaker must be assumed to have had of the way the utterance would be processed and with it the degree of responsibility he must take for the particular conclusions derived. (1986a: $252)^{108}$

Así, junto al contexto más inmediato al receptor, las experiencias vividas, las creencias, las circunstancias personales, la capacidad intelectual, el contexto histórico, el nivel social, etc. construyen el particular contexto cognitivo de cada receptor y es precisamente aquí donde el receptor situará toda la nueva información que procese.

\subsubsection{3. - Efectos contextuales}

Volvamos a la situación que hemos descrito anteriormente. Imaginemos que el decorador escucha a la persona que está hablando por teléfono en la habitación contigua el siguiente enunciado:

(3) - Estoy decorando mi nueva casa con un estilo moderno

Aunque el decorador no es el destinatario de esta información, si que va a utilizarla para reforzar los supuestos (c), (d) y (e). Si, al contrario, escucha la siguiente frase:

(4) - pero hemos decidido darle al salón de nuestra casa un aire rústico

se produce un conflicto entre los anteriores supuestos y el enunciado (4). Obviamente, se utilizará esa nueva información para rechazar el supuesto que tenga un peso menor: en este caso (4) tiene más peso que (c), (d) y (e). La teoría de la relevancia considera que no

${ }^{108}$ Wilson, D. And Sperber, D, 1986a: "Inference and implicature in utterance interpretation" en T. Myers, K. Brown \& B. McGonigle (eds.) Reasoning and Discourse Processes, pp. 241-263. London: Academic Press. 
todos los supuestos tienen la misma fuerza. Byrne establece ciertas prioridades a la hora de examinar el peso específico de cada uno de ellos:

Assumptions will not, of course, all be of equal value in an individual's belief set. The strength of an assumption depends, among other things, on its source. Assumptions retrieved from memory tend to be strong, having been stored as the result of previous convincing evidence. Similarly, assumptions sourced from first-hand experience, such as perception of particular events, will have a higher degree of certainty than those acquired from statements or assertions by somebody else, where the reliability of the information will depend on the hearer's confidence in the informer. The strength of assumptions arrived at by deduction depends on the strength of the premises from which they are derived. (1992: 25)

Sperber y Wilson (1990: 42-43) distinguen mediante los ejemplos que comentaremos a continuación tres tipos de efectos contextuales esenciales para una descripción del proceso de comprensión humano. Todos ellos se producen mediante la interacción entre la nueva información presentada y la información pre-existente en el entorno cognitivo del receptor:

1 - Implicaciones contextuales.

2 - Reforzamientos de supuestos ya existentes.

3 - Contradicciones de supuestos anteriores.

Como ya hemos visto anteriormente, (véase apartado 2.5.3.2.) las implicaciones contextuales se derivan de la combinación entre la información que proviene exclusivamente de los supuestos existentes en nuestra memoria con cierta información de carácter novedoso. Imaginemos que nos despertamos pensando lo siguiente:

(f) - Si llueve, me quedaré en casa.

Nos levantamos, miramos por la ventana y descubrimos (5):

(5) - Está lloviendo 
Del supuesto (f) y de la nueva información (5), podemos deducir la siguiente implicación contextual (6):

(6)- Me quedaré en casa

El segundo tipo de efecto contextual es el reforzamiento de los supuestos preexistentes. Nos levantamos y oímos unos pequeños golpecitos en el tejado de nuestra casa y formamos la siguiente hipótesis:

(g) - Está lloviendo

Salimos a la ventana y descubrimos lo siguiente:

(7) - Está lloviendo

La tercera clase de efectos contextuales es la contradicción y eliminación de los supuestos pre-existentes. Ya hemos mencionado que los supuestos que tenemos en la memoria tienen diferentes grados de fuerza, lo que siempre conduce a la eliminación del más débil. Nos despertamos escuchando unos pequeños golpecitos en el tejado de nuestra casa y formamos la hipótesis:

(h) - Está lloviendo

Salimos a la ventana a comprobarlo y nos damos cuenta de lo siguiente:

(8) - No está lloviendo pero hay gatos en el tejado.

Consecuentemente, eliminaremos el supuesto más débil (h) y lo sustituiremos por (8).

\section{6. - DEFINICIÓN DE LA TEORÍA DE LA RELEVANCIA}

La teoría de la relevancia parte del siguiente principio: el receptor hará el esfuerzo necesario para procesar una información si considera que ésta es relevante en una situación concreta. Una información se considera relevante cuando, al ser procesada en el 
particular entorno cognitivo de cada receptor, produce ciertos efectos contextuales. En los casos más sencillos de la comunicación verbal, el emisor, por el mero hecho de querer comunicarse, garantiza que la proposición que expresa producirá un cierto número de efectos contextuales - siempre que se procese en el contexto que se le supone accesible al destinatario - que hará que el esfuerzo del receptor merezca la pena. Sperber y Wilson defienden que todo acto ostensivo de comunicación, como por ejemplo la emisión de un enunciado, lleva consigo lo que denominan presumption of optimal relevance: "Every act of ostensive communication communicates the presumption of its own optimal relevance" (Sperber y Wilson 1995: 158).

\subsection{1. - La relevancia óptima}

En la teoría de la relevancia se concede una gran importancia a la relación entre efecto y esfuerzo ya que si no se tuviera en cuenta el esfuerzo que el procesamiento requiere, el receptor de un estímulo continuaría procesándolo hasta el infinito, combinándolo con toda la información almacenada en su cerebro con el propósito de comprobar todos los efectos contextuales que puede llegar a producir. Sperber y Wilson (1987: 16) expresan la idea de la relevancia óptima con dos máximas:

A - Other things being equal, the greater the contextual effects, the greater the relevance.

B - Other things being equal, the smaller the processing effort needed to achieve those effects, the greater the relevance.

El destinatario de un enunciado llevará a cabo la interpretación más coherente con el principio de la relevancia: la que requiera menos esfuerzo de procesamiento y que a su vez produzca el mayor número de efectos contextuales. Imaginemos que se produce el siguiente enunciado:

(9) - La obra resultó ser un fracaso 
El emisor de (9) debe tener en cuenta el entorno cognitivo del receptor ya que dependiendo del contexto en el que se pronuncie, su receptor puede llevar a cabo, entre otras, las siguientes interpretaciones pragmáticas:

(a) - Su libro no llegó al número de lectores esperado

(b) - La obra de teatro no salió bien

(c) - El edificio que construyó no le proporcionó los beneficios esperados

(d) - La reforma que llevó a cabo en su casa no le satisfizo

(e) - Su acción benéfica no consiguió el objetivo perseguido

La teoría de la relevancia considera que la comunicación no parte de cero. De esta manera, el receptor escogerá la interpretación que sea coherente con las dos máximas anteriormente mencionadas: la que le proporcione mayores efectos contextuales en su situación determinada por ajustarse mejor tanto a su contexto inmediato como a su conocimiento enciclopédico.

\subsection{2. - Principios de la teoría de la relevancia}

Hemos creído conveniente concluir este apartado con una revisión de las principales nociones que configuran la teoría de la relevancia. Para ello adaptaremos un esquema utilizado por Deirdre Wilson para presentar su teoría de la relevancia durante la celebración de un congreso en la Universidad Complutense de Madrid (1998) por considerar que resume de una manera sencilla los principios fundamentales de su modelo comunicativo.

\section{1. - Cognitive Principle of Relevance}

Human cognition tends to be geared to the maximisation of relevance

2. - Relevance

(i) The greater the cognitive effects, the greater the relevance;

(ii) The smaller the processing effort needed to achieve those effects, the greater the relevance. 
3. - Cognitive effects

(i) Strengthening an existing assumption;

(ii) Contradicting and eliminating an existing assumption;

(iii) Combining with an existing assumption to yield a contextual implication.

4.- Optimal relevance

An utterance is optimally relevant to an addressee if:

(i) it is relevant enough to be worth the addressee's processing effort;

(ii) it is the most relevant one compatible with the speaker's abilities and preferences.

5. - Communicative principle of relevance

Every utterance communicates a presumption of its own optimal relevance.

6. - Relevance-theoretic comprehension procedure

(i) consider cognitive effects in their order of accessibility (i.e. follow a path of least effort);

(ii) stop when the expected level of relevance is achieved.

(Wilson 1998: 2)

\section{7. - PUBLICIDAD Y TEORÍA DE LA RELEVANCIA}

Existen ciertos presupuestos en los que se basa la teoría de la relevancia que si bien pueden ser discutibles al ser aplicados a la comunicación humana en general, nos parecen muy acertados para el análisis de la comunicación publicitaria. Tomemos como prueba el siguiente ejemplo: Sperber y Wilson afirman que la presunción de la relevancia ayuda a explicar tanto la interpretación de los resultados como la producción de enunciados; el emisor tendrá que seleccionar, de entre todos los enunciados posibles, aquel que para su interlocutor pueda dar lugar a los efectos contextuales más satisfactorios con un coste de procesamiento razonablemente bajo. Según la teoría de Sperber y Wilson el emisor siempre utiliza el estímulo que le parece más relevante para la persona cuyo entorno trata de modificar. Este planteamiento es muy acertado para describir lo que ocurre en la comunicación publicitaria ya que el redactor de un anuncio dedica una ingente cantidad de tiempo y esfuerzo a buscar el enunciado (o el estímulo) que produzca el efecto deseado en el entorno cognitivo del destinatario.

Sin embargo, la teoría de la relevancia debe complementarse con otros estudios, pertenecientes al ámbito del análisis del discurso, para poder ser considerada una teoría de la 
comunicación humana. Diversos estudiosos de la comunicación han presentado objeciones a sus postulados. Autores como Talbot (1988) o Walker (1989) consideran que el planteamiento de la teoría de la relevancia es marcadamente reduccionista por tomar la mente humana como un mecanismo de procesamiento de información cuyo único objetivo consiste en mejorar su conocimiento del mundo. Otra crítica, consecuencia directa de la anterior, se refiere a que la teoría de la relevancia presta poca atención a la dimensión social de la comunicación: el lenguaje, además de aportar información nueva, puede utilizarse para crear, mantener o destruir vínculos sociales. Escandell destaca el enfoque casi exclusivamente interpretativo del modelo de Sperber y Wilson:

La teoría quiere dar cuenta de cómo se interpretan los enunciados, y trata de detallar pormenorizadamente los pasos que sigue el destinatario para construir las inferencias que le permitan descubrir la intención de su interlocutor y encontrar una interpretación coherente con el principio de relevancia. Pero apenas nada se dice de la faceta contraria, es decir, de la que se refiere a la producción del enunciado por parte del emisor. (1993: 157)

Reconocemos que la teoría de la relevancia se limita a estudiar un aspecto muy importante en la comunicación humana pero, como mostraremos a lo largo de este apartado, su análisis de la comunicación inferencial resulta imprescindible para una comprensión completa del proceso de comunicación publicitaria y, en particular, del uso que en éste se hace de mensajes escritos en una lengua que no es la esperada por el receptor.

Recordemos en primer lugar que Sperber y Wilson han recalcado que su modelo comunicativo no ha sido exclusivamente concebido para el análisis de la comunicación verbal sino que siempre lo han creído válido para explicar cualquier tipo de comportamiento ostensivo: de este principio se deriva su aplicabilidad a los anuncios publicitarios considerados éstos como unidades comunicativas compuestas de imagen y texto. Asimismo, consideran que el lenguaje es un instrumento que posibilita la comunicación humana, pero no el único medio necesario del que nos servimos: hecho que también es patente en los anuncios donde el texto es sólo un elemento más del mensaje publicitario. 
Comenzaremos este apartado con un análisis de la naturaleza de la comunicación publicitaria que nos conducirá a reflexionar sobre uno de los temas más importantes en la aplicación de la teoría de la relevancia al estudio del mensaje publicitario: nos referimos a la comunicación encubierta.

\subsection{1. - La naturaleza del acto comunicativo publicitario}

Hoy en día, el fenómeno publicitario nos resulta tan familiar que puede llegar a parecernos extraño que cuestionemos su función. Sin embargo, no es difícil encontrarnos con concepciones contrapuestas sobre la naturaleza del discurso publicitario. Así, ciertos autores consideran que su función principal consiste en informar al receptor mientras que otros estudiosos defienden que su cometido esencial es la persuasión del destinatario. Aaker y Myers representan un claro ejemplo de la primera tendencia:

Parecerá más que redundante mencionar que la publicidad, de hecho, informa y que las personas utilizan dicha información para tomar decisiones. A pesar de que publicistas y científicos del comportamiento buscan explicaciones sutiles y a menudo disfrazadas del porqué se registran algunos anuncios publicitarios y otros no, resulta demasiado sencillo pasar por alto el rol obvio y principal de la publicidad como mecanismo de información.(...) Resulta claro que existe una necesidad práctica de información acerca de los productos, y la publicidad que es eficiente tiende a cumplir esa necesidad. (1984: 15)

En el lado opuesto Dyer sostiene que la naturaleza del mensaje publicitario es de carácter persuasivo, utilizando la palabra persuasión en su sentido más peyorativo: manipulación engañosa que afecta a nuestra personalidad y sobre la que no poseemos ningún control. Este autor considera que sus estrategias mercantilistas apelan a nuestras emociones y no son, en absoluto, racionales o informativas. Dyer lo expresa de la siguiente manera:

Advertising central function is to create desires that previously didn't exist.(...) Our desires are aroused and shaped by the demands of the system of production, not by the needs of society or of the individual. It is thus the advertiser's task to try to persuade rather than inform. It is not really surprising that advertisements are unreliable as sources of information 
when one considers that they come from biased or interested quarters, namely the producers of the advertised product. (1992: 6)

Creemos que existen dos circunstancias que pueden ayudarnos a entender concepciones tan diferentes acerca de la naturaleza del mensaje publicitario. La primera radica en la dificultad de encontrar textos puramente persuasivos o textos puramente informativos debido a que ambas funciones suelen aparecer juntas. El segundo problema está relacionado con los intereses que defienden dos colectivos diferentes: los profesionales del mundo publicitario y los críticos del sistema. Los publicistas tienden a recalcar el componente informativo de sus mensajes con el objetivo de conseguir una predisposición social menos beligerante hacia el fenómeno publicitario, mientras que los autores que muestran una postura crítica (Block de Behar 1973, Dyer 1992, Vestergaard and Schroder 1985, etc.) resaltan la naturaleza persuasiva del mensaje, utilizando este término con un significado netamente negativo.

No obstante, parece claro que en los anuncios publicitarios la información está subordinada a la persuasión. Es cierto que la mayor parte de los anuncios informan sobre algún aspecto relativo al producto publicitado - el nombre del producto, su pequeño tamaño, su fiabilidad, su utilidad, etc. - sin embargo no podemos afirmar que ésta sea su función esencial. Es únicamente uno de los medios que pueden ser utilizados para llevar a cabo su primordial objetivo: conseguir la persuasión del receptor.

Tampoco creemos que sea justo caracterizar la persuasión de una manera tan marcadamente negativa. Autores como Lakoff (1981) o Perelman y Tyteca (1989) plantean una definición de persuasión más neutra que la propuesta por Dyer caracterizándola como una argumentación que pretende la adhesión del receptor y cuyo objetivo es llevar a la acción inmediata o futura, es decir, a alcanzar un fin práctico ${ }^{109}$.

Sin profundizar en valoraciones de carácter ideológico sobre la naturaleza de la persuasión publicitaria, únicamente queremos resaltar que la intencionalidad debe ser siempre tenida en cuenta a la hora de llevar a cabo el estudio de la comunicación

\footnotetext{
${ }^{109}$ Por su parte, Vazquez y Aldea proponen la siguiente definición de persuasión: "la persuasión no puede entenderse como algo que una persona ejerce sobre otra, sino - como ha afirmado más recientemente Kathleen Beardom - como un medio por el cual las personas colaboran unas con otras en la conformación de sus versiones de la realidad, privadas o compartidas" (1991: 10).
} 
publicitaria. No debemos olvidar que se trata de un mensaje pagado con una dimensión pragmática muy clara: influir en la conducta de los receptores.

El hecho táctico de que los mensajes publicitarios no manifiesten explícitamente que su objetivo consiste en cambiar nuestra disposición sobre un producto (o servicio) no debe hacernos olvidar que sus mensajes están totalmente condicionados por el imperativo último de la persuasión del receptor. Así, definiremos los anuncios publicitarios como textos normalmente argumentativos de carácter marcadamente persuasivo.

\subsection{2. - La comunicación encubierta en el texto publicitario}

\subsubsection{1. - La cooperación entre emisor y receptor}

La comunicación humana puede ocurrir en situaciones caracterizadas por la existencia de distintos grados de confianza y cooperación entre el emisor y el receptor. Una charla informal entre dos buenos amigos ejemplifica una relación entre dos interlocutores que se consideran como iguales y que se inspiran confianza. Sin embargo, casi nunca se produce la comunicación entre dos personas que muestran total confianza y cooperación: imaginemos una charla de trabajo entre un director de banca y un becario o un diálogo entre un sospechoso y un policía.

La comunicación publicitaria se produce en un contexto que no garantiza en absoluto la cooperación entre destinatario y emisor, lo que, en principio, dificulta la comunicación. Supongamos que un receptor se encuentra en un diario el siguiente mensaje publicitario:

(1) - Palmolive: the best hair-conditioner you can buy.

Lo más razonable es que, debido a la falta de confianza, el receptor no considere la emisión de ese enunciado por parte del publicista como condición suficiente para llegar a creer la anterior afirmación. El destinatario del mensaje sabe que se trata de un anuncio publicitario que, como todos los demás que acostumbra a encontrar, persigue el objetivo de persuadir a sus receptores mediante una argumentación más o menos compleja para 
comprar un determinado producto y no otro similar. Este particular contexto cognitivo propicia que en numerosas ocasiones el redactor publicitario no envíe este tipo de mensajes y que recurra a otras técnicas persuasivas que no presupongan necesariamente una relación de cooperación y confianza entre emisor y receptor.

Una de las prácticas más usuales utilizadas para subsanar este problema consiste en convertir al destinatario en responsable de los supuestos que se pueden extraer del anuncio, obligándole necesariamente a procesarlos. El publicista fuerza al destinatario a llevar a cabo una serie de operaciones deductivas necesarias para entender el texto. Como éstas no son explícitas, y sin embargo son necesarias para interpretar el texto, resulta muy difícil dudar de su veracidad. ${ }^{110}$ En los anuncios publicitarios la información explícita interviene como premisa que invita al receptor a extraer una conclusión implícita. Esta técnica entra dentro de lo que a partir de ahora denominaremos comunicación encubierta:

Advertising is typical of a situation in which the speaker is not trustworthy and the hearer is not trusting. It is mutually manifest to both the advertiser and his adressee that the advertiser is saying something because he wants her to buy a product or service. The advertisers' task is to make her believe something about a product without her trusting him, or, indeed, despite her distrusting him. This leads to a variety of strategies on the part of the advertiser. Covert communication is one of these strategies (...). (Tanaka 1994: 40)

\subsubsection{2. - Definición de comunicación encubierta}

Como muestra la cita anterior, la falta de confianza del receptor respecto al emisor y la escasa cooperación existente entre ambos es lo que determina el uso de la comunicación encubierta. Sperber y Wilson afirman que cuando el emisor no manifiesta, de algún modo, su intención informativa, no podemos hablar de comunicación ostensiva, que es, por su propia naturaleza, abierta. Sobre esta idea, Becherif y Tanaka (1987) han elaborado la siguiente definición de comunicación encubierta que contraponen a la comunicación ostensiva:

\footnotetext{
${ }^{110}$ En el siguiente apartado mostraremos cómo el proceso de persuasión publicitaria comienza en el momento de la percepción del anuncio.
} 
Ostensive communication: an overt form of communication on which there is, on the part of the speaker, an intention to alter the mutual cognitive environmnent of the speaker and the hearer.

Covert communication: a case of communication where the intention of the speaker is to alter the cognitive environment of the hearer, i.e. to make a set of assumptions more manifest to her, without making this intention mutually manifest.

La teoría de la relevancia de Sperber y Wilson distingue entre la intención informativa - "to make manifest or more manifest to an individual a set of assumptions (I)"y la intención comunicativa - "to make it mutually manifest to audience and communicator that the communicator has this informative intention (I)" (1995: 58). Con la comunicación encubierta el emisor intenta informar al destinatario sin poner de manifiesto su intención informativa. Al contrario de lo que ocurre en la comunicación ostensiva, opta por no revelar el propósito perseguido:

He does intend to affect the cognitive environment of his addressee by making her recover certain assumptions, but he avoids the modification of the mutual cognitive environment of the addressee and himself by not making this intention mutually manifest. In other words, he does not publicise his informative intention. (Tanaka 1994: 41)

Los anuncios publicitarios no están interesados en revelar su intención comunicativa ya que el hecho de que los receptores tengan muy presente que el anuncio que están procesando tiene la intención de hacer ganar dinero al publicista y a la empresa que manufactura el producto publicitado, no les va a ayudar en absoluto a persuadir al receptor. Tanaka afirma que la comunicación encubierta se utiliza en publicidad por dos motivos principales: el primero se refiere al deseo del publicista de hacer olvidar al receptor que le está intentando vender un producto y el segundo motivo es tratar de evitar responsabilidades legales por las consecuencias de ciertas implicaciones derivadas de los anuncios. 


\subsubsection{3. - Procesamiento y persuasión}

Un análisis de los anuncios publicitarios siguiendo el enfoque de la teoría de la relevancia nos proporciona una visión muy completa de todo el proceso comunicativo. En este apartado ya hemos mencionado que la publicidad utiliza mensajes cuya función principal consiste en conseguir la persuasión del receptor, y sabemos que la persuasión es un acto de habla perlocutivo. El publicista intenta llevarla a cabo mediante una serie de argumentos, pero no tiene el poder de asegurarla ya que ésta no es una consecuencia inevitable que se produzca al leer un texto persuasivo. Sin embargo, para entender un texto sí que es necesario procesar la información que nos presenta. Por consiguiente, independientemente de que seamos o no persuadidos, en primer lugar debemos comprender e interpretar la información presentada y es en este preciso momento cuando el publicista decide iniciar el proceso de persuasión. Rocío Lineros Quintero (1992: 52) ilustra el proceso persuasivo con el siguiente esquema:
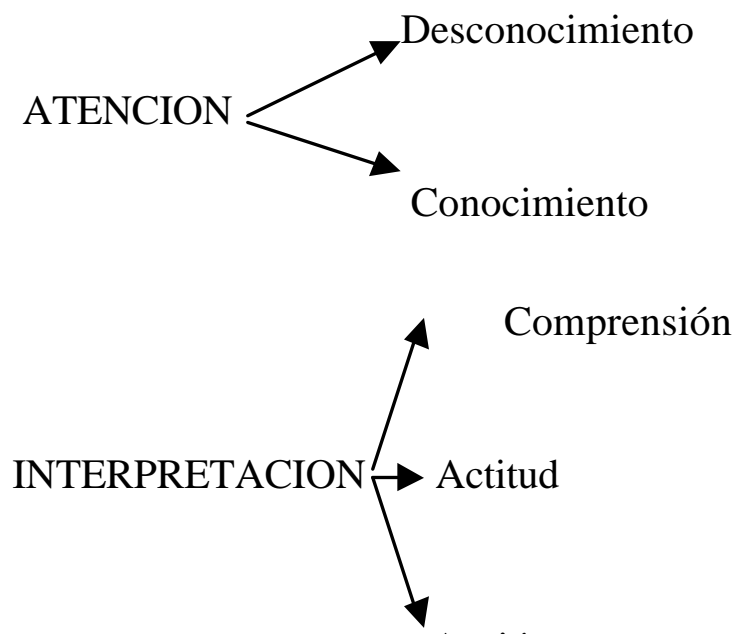

Acción

Quintero destacar que únicamente un pequeño porcentaje de anuncios pasan por el filtro de la atención. Consecuentemente, la persuasión comienza con una llamada de atención al receptor. Una vez detectado el anuncio por parte del destinatario se inicia el proceso que nos conduce al conocimiento y que nos llevará a la interpretación: segunda fase del fenómeno persuasivo. En ella se destacan correlativamente la comprensión del mensaje, 
la actitud hacia el producto y la acción. Sólo si el anuncio tiene éxito, el receptor llevará a cabo la compra del producto publicitado.

Ya hemos visto que en todo proceso comunicativo existe un mayor o menor grado de confianza y credibilidad entre los interlocutores y que, en principio, los receptores no confían en los mensajes publicitarios. El publicista, consciente de ello, no tiene más remedio que conformarse con una discreta cooperación a nivel social y buscar una mayor cooperación a nivel cognitivo, intentando conscientemente involucrar al destinatario en la recuperación de un significado que no es manifiesto. Con esta reflexión descubrimos una segunda razón para el uso de las implicaturas: además de recurrir a ellas para que al receptor le resulte más difícil dudar de su veracidad, también se utilizan para implicar al receptor en el mensaje contribuyendo a conseguir el objetivo perseguido. No debemos olvidar que es en el proceso de comprensión donde actúa con mayor fuerza la persuasión publicitaria: así el publicista calcula cuidadosamente la información que presentará de forma explícita en el anuncio dejando una buena parte de ella implícita: "The important consideration is, of course, not what the advertisement is meant to mean or convey - the whole point of the advertisement is for the hearer to access the intended implications" (Byrne 1992: 35).

\subsubsection{La implicación del receptor}

La mayor ventaja de la aplicación de la teoría de la relevancia a los anuncios publicitarios reside en el importante papel que se reserva al receptor del anuncio y a su contexto particular. Sperber y Wilson, en contraposición a los planteamientos semióticos, muestran que la función del receptor es decisiva en todo proceso comunivativo. En el caso de la comunicación publicitaria este hecho es mucho más evidente debido a factores como la situación de los anuncios en el entorno de nuestra atención, su omnipresencia en nuestra sociedad, la desinteresada actitud del destinatario de estos mensajes, etc.

Los anuncios publicitarios se ubican en la periferia de nuestra atención (Cook 1992: 217): compramos un diario para conocer las últimas noticias y no para leer su publicidad; encendemos el televisor para disfrutar de una película y no para ver los anuncios, etc. De ahí que el anuncio tenga que hacer en primer lugar el esfuerzo de llamar nuestra atención. Si el receptor no decide dedicar unos segundos a procesar el mensaje que el publicista le envía, no se producirá una interacción entre la nueva información y su contexto cognitivo y 
consecuentemente, no se originarán los efectos contextuales perseguidos por el emisor. Recordemos que Sperber y Wilson consideran que la comunicación se produce cuando se lleva a cabo una modificación del contexto cognitivo del receptor.

Conseguir la atención de la audiencia es uno de los mayores problemas de la publicidad actual ya que aunque el emisor del mensaje publicitario tiene asegurada la presencia física de cierto número de receptores, no tiene asegurado el necesario esfuerzo de atención que posibilite que la comunicación se lleve a cabo:

While the average hearer in the canonical conversational situation (...) will make a minimum effort to process utterances no matter how boring, rather than appear impolite, the advertiser has no certainty of a captive audience even if the physical presence of the audience can be guaranteed. (Byrne 1992: 6)

A ello hay que añadir un segundo problema: la predisposición del receptor respecto a los anuncios publicitarios. A mediados de la década de los sesenta Geoffrey Leech consideraba que "the average person's attitude to advertising is bored tolerance" (1966: 5). Hoy en día, la situación ha cambiado sustancialmente y los espectadores - o lectores muestran una actitud muy crítica hacia el bombardeo de anuncios al que están sometidos cada vez que abren un periódico o encienden el televisor. Comienza a aparecer un tipo de receptor que rechaza de antemano unos mensajes que sabe que únicamente persiguen un objetivo: venderle el que supuestamente es el mejor producto del mercado.

El creativo publicitario intenta paliar este problema buscando fórmulas innovadoras que permitan que su mensaje se diferencie del maremagnun de mensajes similares con el propósito de conseguir la ansiada implicación del receptor, piedra angular de la publicidad contemporánea. Una de las técnicas más comunes consiste en construir un mensaje con una imagen seductora y redactar el texto con un estilo de lenguaje que resulte interesante para el destinatario.

El estilo del lenguaje publicitario puede parecer similar al poético debido al uso de figuras como los juegos de palabras, metáforas, anáforas, etc. Su objetivo es hacer que el texto resulte atractivo para intentar captar la atención del receptor y para ello, al igual que las obras literarias, recurren a las implicaturas, invitando al receptor a interpretar el mensaje. Sin 
embargo, existe una gran diferencia entre la literalidad de un anuncio y la literaridad de un texto literario:

While advertising resembles the literary text in that it can depend on weak implicatures to achieve communication by means of an interesting poetic style, there is the difference that, whereas added processing may be seen to increase the "literariness" of literary texts, in advertising there is always a general direction or area of contextual implications that the advertiser wishes the hearer to access. (Byrne 1992: 34)

Los textos publicitarios presentan las implicaturas que suponen serán recuperadas por el destinatario que persiga la relevancia óptima. Estas implicaturas tienen una función principal: modificar el contexto cognitivo del receptor en una dirección determinada con el objetivo de conseguir su persuasión. La comunicación por medio de implicaciones débiles comporta ciertos riesgos ya que su interpretación es responsabilidad exclusiva del receptor. Sin embargo, el publicista asume ese peligro de buen grado:

(...) cada lector que recibe un mensaje puede extraer un conjunto de inferencias diferentes, y en el transcurso del proceso puede llegar a activar interpretaciones que nunca fueron pensadas por el emisor. Este peligro no parece preocupar al creativo publicitario, que prefiere que su mensaje despierte la imaginación antes de que quede relegado al olvido. (Díez 1998: 62)

El emisor debe considerar las ventajas y los inconvenientes de utilizar un estilo interesante para el destinatario, que resulta más atractivo pero implica un mayor procesamiento, o recurrir a un estilo muy claro, menos atractivo y que implica un menor procesamiento. Por la propia naturaleza del mensaje publicitario, el emisor tiende a inclinarse por la primera opción: "Giving too much information and including in the utterance items which the hearer could readily access from contextual implications (...) can make the communication sound boring and patronising" (Byrne 1992: 6).

Otro de los recursos que el creativo publicitario utiliza con el objetivo de gratificar al receptor por la atención prestada son las ilustraciones. Los anuncios en prensa recurren, entre otros elementos, a imágenes atractivas. Cook afirma que una de las principales 
funciones de la imagen en el mensaje publicitario es recompensar al receptor por la atención prestada:

The hearer often does not get her reward entirely through inference in covert communication, for the speaker exploits the fact that humans get a kind of pleasure out of processing certain stimuli. Advertisers, for example, include illustrations to compensate the addressee for her attention. (1992: 225)

\subsection{3. - Analisis de las implicaturas en un anuncio publicitario}

Comenzaremos este apartado mencionando dos estudios citados en diversas ocasiones a lo largo de este trabajo por haber vinculado con éxito el modelo comunicativo propuesto por Sperber y Wilson al análisis de los anuncios publicitarios. Nos referimos al libro Relevance theory and the language of advertising de Barbara Byrne y Advertising language: a pragmatic approach to advertisements in Britain and Japan de Keiko Tanaka. Aunque el tema general de ambos libros sea bastante similar, el enfoque de las dos obras es distinto. Byrne plantea un análisis del estilo lingüístico de la publicidad, prestando una atención preferente a las implicaturas contextuales: "This study argues that Relevance Theory is therefore an ideal tool for analysing the effectiveness of communication through the creative linguistic style of advertising, which is geared to a large target audience often widely scattered" (1992: 5). Por su parte, Tanaka presta una mayor atención a los factores que condicionan el procesamiento que el emisor hace de los anuncios publicitarios: "The main purpose of this study is to give an adequate analysis of the language of written advertising in Britain and Japan, within the framework of pragmatics, and to explain how communication occurs between the advertiser and audience" (Tanaka 1994: XI).

Además del libro anteriormente citado, Tanaka ha publicado diferentes estudios en los que aplica la teoría de la relevancia a distintos elementos presentes en los textos publicitarios: la metáfora, los juegos de palabras, el particular lenguaje de los anuncios de fragancias, la representación de la mujer en la publicidad japonesa, etc. Sus trabajos parten de un análisis lingüístico que progresivamente va derivando hacia ciertas conclusiones de carácter sociológico que, como mostraremos a continuación, tienden a 
resultar exageradas. Ya hemos comentado (véase el apartado 2.7.2.2.) que esta autora encuentra dos razones básicas que llevan a los publicistas a utilizar la comunicación encubierta: el deseo de hacer olvidar al destinatario que le están intentando vender un producto y evitar responsabilidades por las consecuencias sociales que podría traer haber comunicado explícitamente la información que figura implícita en el anuncio. El publicista desea comunicar determinada información al destinatario pero no quiere hacerse responsable de ella. Consecuentemente opta por recurrir a la comunicación encubierta.

Tanaka (1994: 48) destaca que las interpretaciones de carácter sexual son las más comúnmente utilizadas en publicidad y muestra ejemplos de comunicación encubierta de naturaleza netamente sexual en anuncios de productos tan diversos como el whisky, las fragancias, los televisores portátiles, etc. En este apartado creemos conveniente comentar brevemente el análisis que Tanaka lleva a cabo de las implicaturas sociales derivadas de un anuncio de relojes Ellesse publicado en la edición británica de la revista Elle en Diciembre de 1992.

El anuncio al que hacemos referencia (figura 6) consta de los elementos clásicos de la publicidad en prensa ${ }^{111}$ que pasamos a detallar a continuación:

\section{Titular - Designed to perform}

Subtitular - Ellesse watches, style with sports action

Ilustración - Presenta a un hombre y una mujer con bañador y gorro de piscina, lo que nos indica que se trata de dos nadadores.

Cuerpo del texto - Aquí se enumeran las diferentes características técnicas del reloj, mayormente relacionadas con su utilización bajo el agua: sumergible a 200 metros, correa de piel de tiburón, etc.

Rúbrica - Ellesse watch.

Siguiendo el contenido del texto y de la ilustración, el destinatario parece invitado a derivar la siguiente implicatura:

\footnotetext{
${ }^{111}$ En el apartado 3.2.1.3. de nuestro trabajo prestaremos atención a los diferentes elementos que componen la estructuración tradicional de los anuncios en prensa (titular e ilustración, cuerpo del texto y rúbrica) para posteriormente vincular las funciones que cada uno de ellos desempeña al uso de la lengua inglesa.
} 
(1) - Los relojes Ellesse han sido diseñados para funcionar adecuadamente en situaciones deportivas que requieren un buen reloj como, por ejemplo, la natación.

Sin embargo, Tanaka, atendiendo exclusivamente a la ilustración que presenta el anuncio, encuentra una segunda implicatura de carácter netamente sexual:

the illustration also has strong overtones of a relationship between the two figures. They are holding each other in a rather intimate way, with the man's hand on the woman's thigh. The whole picture is in a provocative shade of red. The audience could thus easily recover: Ellesse watches help you with sexual performance. But the advertiser can easily deny that he ever meant to communicate: Ellesse watches are designed to perform well in sporting situations in which a good watch is necessary. (Tanaka 1994: 53)

No creemos que el propósito del publicista sea intentar que el receptor infiera la necesidad de la adquisición de un reloj para mejorar su vida sexual ni creemos que haya un significativo número de personas que así lo interpreten. A nuestro juicio, su único objetivo reside en transmitir, valiéndose de una ilustración, un mensaje del que se puedan derivar tonos de experimentación, aventura, transgresión, etc. atractivos para el receptor. Con la intención de propiciar la atención al mensaje el publicista utiliza una imagen sugerente y agradable. La propia Tanaka nos proporciona la clave para interpretar este fenómeno:

The slightest hint of sex draws an audience attention, because the cognitive system of human beings is organized in such a way that it is more susceptible to this kind of information than to other kinds. Generally, covert communication manipulates triggers to which the human mind is highly susceptible. (1994: 54)

Además de conseguir la atención del receptor, el uso de este tipo de imágenes responde a la función de crear, por medio de ciertas implicaturas sociales, un sentimiento de cooperación y camaradería con el destinatario del anuncio: el emisor desempeña el papel de una persona que comparte criterios coincidentes con los del receptor. De esta forma se procurará solventar la falta de confianza y cooperación existente entre emisor y destinatario, uno de los factores que pueden poner en peligro el éxito de la comunicación publicitaria. 
El uso de mensajes de los que se pueden derivar ciertos ecos de transgresión es muy habitual en la publicidad contemporánea. Recordemos aquí campañas como la de Yves Saint Laurent para lanzar una de sus nuevas fragancias (véase la figura 7). En ella se busca la asociación de un perfume con la flor de la adormidera, conocida por sus productos derivados: particularmente el opio. La ilustración utilizada en este anuncio muestra muchas similitudes con la adormidera (véase la figura $8^{112}$ ): la modelo está tumbada en una postura que indica un goce extremo sobre un fondo de color morado, color característico de los capullos de la flor del opio. La disposición y la textura de la tela de su vestido se asemeja a los pétalos de una flor y además tiene el mismo color rojizo incluso con los característicos reflejos amarillos de la adormidera. El único mensaje lingüístico sirve para dar nombre al producto, que es como no Opium, lo cual no deja dudas acerca de esa relación. En otros anuncios de la misma campaña (véase la figura 9) se mantiene en la ilustración el uso de los colores morado, rojizo y reflejos amarillos. La fotografía va acompañada por enunciados de los que se puede inferir una relación entre el opio y la fragancia publicitada:

Opium: para las que se entregan a Yves Saint Laurent.

(Figura 9)

Con el anterior análisis parece más que evidente el deseo por parte del creativo publicitario de establecer una identificación entre la flor de la adormidera y la nueva fragancia. Sin embargo, no sería justo pensar que el publicista está invitándonos a inferir que los efectos de esa fragancia son similares a los de la heroína: la sustancia que más comúnmente se asocia al opio. Su único objetivo radica en enviarnos un mensaje sugerente con ciertos tonos de transgresión que captará nuestra atención y facilitará la necesaria cooperación para conseguir que se produzca la comunicación.

112 Esta fotografía de la flor de la adormidera aparece en la Enciclopedia Temática Planeta: Botánica, Zoología, Ecología editada por Planeta en el año 1974. 


\section{PRESENCIA DE LA LENGUA INGLESA EN LA PUBLICIDAD ESPAÑOLA: ANÁLISIS LINGÜÍSTICO DEL CORPUS}

\section{1. - ESTADO DE LA CUESTIÓN}

El uso de la lengua inglesa en la publicidad española ha merecido algunos breves comentarios por parte de estudiosos del lenguaje publicitario en secciones normalmente dedicadas a la innovación léxica en el mensaje publicitario. Este fenómeno ha sido estudiado conjuntamente con otros elementos característicos del discurso publicitario como la acuñación de neologismos, el uso de anglicismos, la prefijación y sufijación extranjerizante, la creación de términos compuestos, la adopción de una terminología pseudocientífica, etc.

Además de las aportaciones lingüísticas llevadas a cabo en este campo, desde una perspectiva estrictamente sociológica también se ha puesto de manifiesto que uno de los síntomas más extremos del influjo angloamericano en la sociedad española reside en el hecho de que ciertos anuncios publicitarios lleguen a presentar su mensaje utilizando exclusivamente la lengua inglesa. Estudiosos como Moncada (1995) o Crystal (1997) destacan la existencia de este fenómeno como prueba de la supremacía económica mundial de los países de habla inglesa: principalmente de los Estados Unidos de América.

Sin embargo hasta el momento no tenemos noticias de que se haya llevado a cabo un estudio sistematizado del tema en cuestión. Dedicaremos el siguiente apartado de nuestro trabajo a revisar diferentes estudios de carácter lingüístico, normalmente basados 
en el modelo del código, donde se reflexiona acerca del uso de la lengua inglesa en la publicidad española. Las referencias a estas publicaciones se harán siguiendo un estricto orden cronológico. Posteriormente propondremos una explicación alternativa basada en la comunicación inferencial propugnada por el modelo comunicativo defendido por la teoría de la relevancia de Sperber y Wilson.

\subsection{1. - El análisis tradicional basado en el modelo del código}

Geoffrey Leech, en un estudio que se puede considerar como clásico en el campo del lenguaje de la publicidad escrita en lengua inglesa, hace una primera reflexión sobre el fenómeno que aquí nos ocupa considerando que el uso de un idioma distinto al esperado por el receptor se explica como una licencia poética del redactor del anuncio cuyo principal valor reside en introducir un nuevo componente que aporte cierta gracia al texto del anuncio. Al tratarse de un estudio sobre anuncios publicados en Gran Bretaña menciona el siguiente ejemplo:

A headline in an advertisement for flights to Mexico in fact contained a very similar device: “iSooner than mañana!”. Here the impropriety consisted in using Spanish punctuation and a Spanish word in an advertisement which was otherwise in English. (1966: 176)

Dentro de los trabajos de investigación sobre la publicidad escrita en español y partiendo de un planteamiento semiótico que, como todos los enfoques de este tipo, se fundamenta en las premisas existentes en el modelo del código, Feliú establece cinco tipos de connotación en la comunicación publicitaria - metalingüística, poética, emotivoevaluativa, conativo-apelativa y fática - situando el uso de un idioma distinto al del receptor dentro de la connotación metalinguística:

[La connotación metalingüística] tiene gran importancia en la publicidad, y se basa en el empleo de elementos lingüísticos que se desvían del código establecido. La ampliación de los códigos en la publicidad puede llegar hasta la incorporación de elementos de otro código lingüístico, de otra lengua, aunque ésta es una de las formas más extremadas. (...) La elección de los términos 
extranjeros es uno de los múltiples artificios evocadores que derivan su efecto no de una cualidad intrínseca, sino de estar asociados a un ambiente o un registro de estilo particulares. (1983: 119)

En este mismo año, López Frías lleva a cabo un análisis comparativo entre el lenguaje publicitario inglés y el español. En la introducción a su estudio hace hincapié en el carácter persuasivo del mensaje publicitario, poniendo de manifiesto el uso que se hace del lenguaje en este particular acto comunicativo con el único objetivo de convencer al receptor sobre las bondades de un producto o servicio. Este autor destaca que si la utilización de una lengua extranjera sirve al anterior propósito el publicista no dudará en recurrir a ella:

La publicidad, con tal de conseguir sus objetivos será capaz de cualquier cosa. No le importará elegir las palabras menos precisas o las de menos contenido e incluso recurrirá, si le conviene, a las lenguas extranjeras y no precisamente para aclarar su exacto significado sino acaso por lo contrario; y todo ello sin una justificación convincente salvo para sus propios objetivos. (1983: 84)

Por su parte, Lineros Quintero distingue tres niveles en el mensaje lingüístico de un anuncio: el de la configuración, el expresivo y el de contenido. Dentro del plano de la expresión establece tres tipos de manipulaciones del lenguaje: por obliteración, por suspensión y por transgresión. Todas ellas tienden a crear lo que Lineros define como la función enigmática del acto comunicativo publicitario. El uso del inglés en la publicidad española entraría dentro de la función enigmática de la transgresión:

El fenómeno de transgresión junto con la suspensión o sustitución de significantes es casi consustancial a la publicidad y puede adoptar las más variadas formas; una de las más extremadas es la utilización de otro código lingüístico como son los usos de las lenguas extranjeras que caracterizan no sólo este mensaje lingüístico sino también el mensaje de pertenencia al género si tenemos en cuenta el valor retórico que posee. (1992: 144)

En Aproximación al estudio del lenguaje publicitario en inglés: aspectos semánticos y pragmáticos, Lanao Bernald encuentra dos razones prácticas, ambas 
relacionadas con la pérdida de importancia del texto frente a la imagen, que explican la aparición de anuncios completamente escritos en inglés en la prensa española:

Por un lado se debe al fenómeno de la progresiva pérdida de importancia del texto frente a la imagen, que llega a casos tan extremos como el de los anuncios de "Silk Cut" en los que no se menciona ni representa el producto, ni hay texto de ningún tipo, sólo un corte en una pieza de seda de color morado. Por otro lado esta actitud se ha de contemplar desde el punto de vista de la sociopragmática: al ser textos muy breves se supone que los anuncios van destinados a consumidores que conocen poco o nada la lengua inglesa, pero que quizás precisamente por eso otorgan una gran importancia al modo de vida que representa y al hecho de dominar el inglés como lengua extranjera. El texto sería un mero ornamento. (1992: 278)

Ferraz Martínez, desde una perspectiva claramente semiótica que le lleva a definir el lenguaje de la publicidad como el resultado de una conjunción de signos diversos icónicos y verbales principalmente - atribuye el uso de lenguas diferentes de la esperada por el receptor a una de las funciones del mensaje lingüístico en relación con la imagen: la función de transgresión del código esperado. Este autor destaca las ventajosas connotaciones producidas al asociar un bien de consumo con su país originario:

El recurrir a lenguas diferentes de la esperada por el receptor, a la hora de codificar todo el texto o parte del mismo, connota los mensajes publicitarios. Así, una conocida marca de cigarrillos americanos se ha anunciado en nuestro país con este texto que realza la americanidad del producto: "The Chesterfield way of life." Este tipo de valores connotativos son muy rentables por las asociaciones que se establecen entre bienes de consumo y países de origen. (1993: 25)

Al poner de manifiesto el carácter multinacional de la mayoría de las campañas publicitarias Díez Arroyo destaca que generalmente las adaptaciones a nivel nacional únicamente tienen lugar a efectos verbales ya que los códigos no verbales que la publicidad utiliza suelen ser de carácter transnacional. Díez afirma que cuando no se produce la adaptación del contenido lingüístico del anuncio, el creativo publicitario opta por utilizar la estrategia de acentuar la autenticidad del producto publicitado: 
Generalmente estos códigos [publicitarios] son compartidos por amplios sectores de población, llegando incluso a traspasar fronteras nacionales. Piénsese que hoy en día la mayoría de las campañas publicitarias están diseñadas por multinacionales, y las adaptaciones a nivel nacional tienen lugar únicamente a efectos verbales (y en muchos casos ni siquiera se llega a eso: anuncios franceses de perfumes aparecen con relativa frecuencia en revistas inglesas, españolas, italianas, etc. En este caso mantener la lengua original es un símbolo de prestigio y autenticidad que beneficia al producto.) (1995: 55)

Con los ejemplos que acabamos de reproducir hemos querido poner de manifiesto la tendencia general existente a la hora de explicar el uso de la lengua inglesa en la publicidad española siguiendo las premisas marcadas por el modelo del código. Por una parte hemos comprobado que este uso ha sido considerado como una manera de asociar el bien de consumo publicitado con su país de origen confiriéndole prestigio, autenticidad y un cierto valor añadido mediante las connotaciones que se derivan de la utilización de la lengua inglesa. Por otra parte, distintos autores han destacado que la introducción de palabras o expresiones en diferentes idiomas es una característica propia del particular registro que utiliza el mensaje publicitario destinado a conseguir la persuasión del receptor. Sin embargo, en todos los estudios anteriormente mencionados echamos en falta una explicación sobre la forma en que esta particularidad del discurso publicitario ayuda a conseguir la ansiada persuasión del destinatario. Dedicaremos los siguientes apartados de nuestro trabajo a analizar este punto prestando una atención especial a los diferentes factores que condicionan el acto comunicativo publicitario.

\subsection{2.- El análisis basado en la teoría de la relevancia}

Con el análisis estadístico llevado a cabo en el apartado 1.7. de este trabajo hemos querido poner de manifiesto la abundancia tanto de anuncios con expresiones en lengua inglesa como de textos publicitarios íntegramente escritos en dicho idioma en la prensa actualmente publicada en España. Este hecho que, según nuestra impresión, aumenta día a día constituye una prueba irrefutable de que, en el ámbito de la publicidad, las expresiones o mensajes redactados en inglés no sólo no imposibilitan la comunicación sino que además favorecen este particular acto comunicativo: si no fuera así, el discurso 
publicitario no recurriría a ellos con la asiduidad que muestra hoy en día. Después de haber recordado la importancia del fenómeno aquí descrito y una vez examinadas las explicaciones propuestas en el apartado anterior, pasamos a considerar diferentes conceptos que resultan claves para entender esta particular estrategia de alternancia de usos lingüísticos, estrategia que ya podemos considerar como una característica propia del discurso publicitario actual.

\subsubsection{1. - La lengua inglesa como técnica de captación de atención}

Como ya hemos comentado anteriormente y siguiendo los criterios del modelo lingüístico propuesto por Sperber y Wilson partimos de la siguiente premisa: al igual que ocurre en todo acto comunicativo, la comprensión de los mensajes publicitarios no depende exclusivamente de un proceso de codificación-descodificación estrictamente establecido ya que buena parte de los enunciados presentes en los anuncios invitan al receptor a llevar a cabo operaciones deductivas de carácter inferencial donde el contexto enriquece la nueva información y la convierte en información relevante. La información nueva, o presentada como nueva en los anuncios, se comunica y procesa atendiendo al entorno cognitivo del destinatario: "As with other types of communicated messages, advertising can only be relevant to the hearer when it interacts with existing information in his cognitive environment to produce contextual effects" (Byrne 1992: 34).

Por su propio conocimiento de esta particular clase de discurso, el destinatario de textos publicitarios supone que toda la información presente en un anuncio responde a una cierta lógica. Para encontrarla se verá ayudado por lo que Van Dijk (1986: 83) ha definido como "marcos de conocimiento" cuya principal función es organizar en la mente del receptor las distintas acciones que forman parte de las diversas clases de interacción social: en esta ocasión se trata de la lectura de un anuncio publicado en una revista ${ }^{113}$. Los marcos de conocimiento posibilitan que el destinatario no sienta extrañeza a la hora de encontrarse con un texto publicitario facilitando, en cierta medida, la interpretación de

${ }^{113}$ Garrido (1994: 173) considera que los anuncios son textos caracterizados por su función comunicativa publicitaria y define el concepto de texto como una unidad de comunicación que sigue una forma más o menos convencional de organización de la información que transmite y que tiene un origen cultural y social. 
todos los recursos que en éste se utilicen como, por ejemplo, la intencional aparición de un código distinto al esperado.

En este contexto, el destinatario es invitado a procesar la nueva información y a llevar a cabo una determinada interpretación que puede ser la pretendida por el emisor o no: si lleva a cabo las inferencias que el emisor espera, la comunicación será un éxito. Para ello deberá integrar la suma de información procedente de las imágenes y la información lingüística con su particular información contextual y establecer las conexiones necesarias entre todas las informaciones presentes con el objetivo de obtener el máximo efecto con el menor esfuerzo de procesamiento.

Una vez que hemos establecido el marco general donde se debe ubicar el acto comunicativo publicitario, pasamos a examinar una de las razones por las que el publicista opta por transmitir cierta información utilizando un idioma que no es de uso habitual para los destinatarios de los anuncios a los que va dirigido ${ }^{114}$. En el apartado anterior hemos examinado hs explicaciones basadas en el modelo del código. Pasemos ahora a estudiar este fenómeno considerando los postulados de la comunicación inferencial.

Desde el punto de vista de la teoría de la relevancia presentar un estímulo lingüístico mediante un código que no es el esperado por el destinatario debe interpretarse, en primer lugar, como una segunda llamada de atención dentro del acto comunicativo publicitario que, por su propia naturaleza, comienza su particular proceso persuasivo con un intento de atraer la atención de su audiencia (véase el apartado 2.7.2.3.). El uso de la lengua inglesa en parte de un anuncio mayormente redactado en español o la publicación de un anuncio escrito en inglés en una revista española puede interpretarse como una técnica de captación de atención dirigida, en principio, a los destinatarios más reticentes a participar en el acto comunicativo publicitario ya que la utilización del inglés es un comportamiento no habitual en las situaciones comunicativas cotidianas de los lectores de estos anuncios y, como afirma Leech, "any kind of unconventional behaviour, linguistic or otherwise, compels notice" (1966: 27).

${ }^{114}$ Como ya hemos visto en el apartado 1.7.2.2. las ofertas de empleo publicadas en inglés en la prensa española no responden a estas características ya que, al menos en ciertas ocasiones, se dirigen a destinatarios que utilizan habitualmente la lengua inglesa o que tienen la capacidad de utilizarla. 
El uso de la lengua inglesa, tanto en textos opacos para el gran público como en textos más fácilmente comprensibles, asegura que un buen número de receptores perciba que el discurso publicitario tiene más fuerza, atrayendo y manteniendo de esta manera la atención de su audiencia y combatiendo así la mayor preocupación de todo publicista: que su anuncio pase desapercibido y no consiga establecer contacto con su destinatario.

\subsubsection{La búsqueda de complicidad con el destinatario}

En apartados anteriores (véase el apartado 2.7.2.1.) hemos puesto de manifiesto que la comunicación publicitaria se produce en un contexto que no garantiza en absoluto la cooperación entre destinatario y emisor debido, sobre todo, a que el primero es consciente de la finalidad perlocutiva que este particular acto comunicativo persigue. También hemos comentado que una de las prácticas más comúnmente utilizadas para subsanar el problema consiste en responsabilizar a la audiencia de los supuestos que extrae del anuncio: el redactor publicitario fuerza al destinatario a llevar a cabo ciertas operaciones deductivas implícitas que son necesarias para entender el texto y que, a su vez, dan lugar a diversos efectos contextuales que resultan positivos para el producto. El hecho de proporcionar exclusivamente la información necesaria para llegar a recuperar las implicaturas perseguidas por el publicista responde a dos motivos. Por una parte, el carácter implícito de estas operaciones hace más difícil dudar de su veracidad. Por otra parte, manifiesta un deseo de búsqueda de complicidad:

The more information she leaves implicit, the greater the degree of mutual understanding she makes it manifest that she takes to exist between her and her hearer. Of course, if she overestimates this degree of mutual understanding, there is a risk of making her utterance harder or even imposible to understand. It is not always easy to strike the correct balance: even a slight mismatch between speaker's estimate and hearer's abilities may make what was merely intended to be helpful seem patronising or positively offensive to the hearer. (Sperber y Wilson 1995: 218)

La complicidad es una de las estrategias más buscadas por los publicistas para contrarrestar la desconfianza que el acto comunicativo publicitario produce en el destinatario y para ello recurren a diversas técnicas que caracterizan el estilo del discurso 
publicitario: juegos de palabras, textos de carácter irónico, recursos fónicos (aliteración, paronomasia y rimas entre otros), modificación de frases hechas, explotación de situaciones ingeniosas, etc. Si el destinatario considera que el anuncio es inteligente, divertido o atrevido puede desarrollar un sentimiento solidario de complicidad con el mensaje y la percepción del producto saldrá beneficiada.

Uno de los propósitos que también se persigue mediante el uso de la lengua inglesa en la publicidad española responde al deseo de búsqueda de cooperación con los destinatarios familiarizados con este idioma, como veremos en numerosas ocasiones en el análisis de nuestro corpus. Después de que el creativo publicitario haya establecido contacto con su audiencia, ayudado en numerosas ocasiones por diversos mecanismos de captación de atención ${ }^{115}$, sus esfuerzos se dirigen a conseguir la cooperación del destinatario en el acto comunicativo. El uso de la lengua inglesa en la publicidad española puede conseguir ambos objetivos, actuando a su vez como un reclamo y un recurso estilístico más del discurso publicitario, sirviendo entonces al propósito de lograr la complicidad con las personas con cierta competencia en lengua inglesa. Veamos un ejemplo.

En ocasiones, el redactor publicitario intenta halagar al destinatario del anuncio presentándole un mensaje en lengua inglesa breve formado por palabras que bien no difieren en exceso de sus correspondientes términos en español o bien son relativamente conocidas. La interpretación de estos breves textos, fácilmente traducibles, produce una satisfacción en el destinatario que, de esta simple manera, se siente incluido en el grupo de personas que comprenden la lengua inglesa. Consideramos que buena parte de la población española expuesta a los medios de comunicación de masas escritos tiene una cierta competencia en lengua inglesa que le permite comprender textos sencillos: una gran mayoría de los lectores del anuncio protagonizado por Eva Herzigova publicitando el Wonderbra comprende su escueto mensaje textual: Hello, boys! $!^{16}$. Cuando el procesamiento se lleva a cabo con éxito y el destinatario entiende el significado del enunciado, éste experimenta un cierto placer mental similar al que advierte cuando

\footnotetext{
${ }^{115}$ El discurso publicitario dispone de numerosos mecanismos de captación de atención: el uso de ilustraciones o fotografías, el particular estilo de los titulares, los juegos tipográfícos del anuncio que en el argot publicitario se conocen como display language, etc.

${ }^{116}$ No obstante, el significado del nombre del producto - Wonderbra - resulta inaccesible para la mayor parte de sus destinatarios.
} 
resuelve las múltiples incoherencias intencionales características del discurso publicitario. La satisfacción de haber estado a la altura de las circunstancias producirá en el destinatario nuevos efectos contextuales. Esta estrategia ayuda a transformar la actitud reticente del público hacia el acto comunicativo publicitario por una actitud neutra o incluso positiva.

\subsubsection{3. - El comportamiento comunicativo relevante}

La teoría de la relevancia proporciona un marco apropiado para llevar a cabo el análisis del uso de la lengua inglesa en la publicidad española también en lo relativo al tema del esfuerzo de procesamiento. Siguiendo los principios de esta teoría, podría argumentarse que recurrir a un idioma que no es el de uso habitual obligaría al destinatario a llevar a cabo un esfuerzo de procesamiento gratuito que parece ir en contra de los principales presupuestos establecidos en la teoría de la relevancia (véase el apartado 2.6.2.). Sin embargo, aunque la utilización de un código no esperado por el destinatario sea, en principio, más costosa que el uso del español, los efectos contextuales que se derivan del enunciado en lengua inglesa tienen un mayor peso que el esfuerzo extra. Haciendo alusión al uso de diferentes efectos estilísticos, Wilson y Sperber (1987: 19) ponen de manifiesto que en ciertas ocasiones "by demanding extra processing effort (...) the speaker can encourage the hearer to look for aditional contextual effects in the form of additional weak or strong implicatures". En esta ocasión, la relevancia óptima se consigue a pesar del mencionado esfuerzo de procesamiento ya que constituye la manera más económica de conseguir los efectos contextuales perseguidos.

El particular acto comunicativo al que estamos haciendo referencia también es relevante desde una perspectiva cognitiva al obligar al destinatario a tomarse un tiempo que resulta necesario para procesar esa nueva información y que parece facilitar la memorización. El propio Leech vincula la facilidad para recordar los anuncios publicitarios a dos factores: por una parte la repetición característica del discurso publicitario $^{117}$ y por otra parte el impacto que haya conseguido en el destinatario la primera vez que se produce el acto comunicativo:

117 "By dint of repetition, whether in a single commercial or a whole advertising campaign, the consumer may be brought to the point where the brand-name and some catch-phrase associated with it are mutual recall stimuli, so that the product is, so to speak, stored in his mind with a permanently attached label" (Leech 1966: 29). 
What makes one piece of language intrinsically more memorable than another? To some extent, the ease with which we remember things depends on the impact it first made on us; in this the goal of memorability coincides with that of attention value. (1966: 29)

Byrne (1992: 53) vincula el impacto que produce un anuncio en la audiencia y su posterior rememoración a la cantidad de implicaturas contextuales, consciente o inconscientemente buscadas por el publicista, que recupere el destinatario. Para explicar este fenómeno recurre a un anuncio de agua mineral Tipperary transmitido el dieciocho de agosto de 1988 por la emisora RTE Radio 2. Este autor afirma que la cuña publicitaria anteriormente mencionada aprovecha las implicaturas contextuales que puedan surgir en el contexto cognitivo del destinatario debido, entre otros elementos, al nombre del producto - que hace referencia a un conocido pueblo irlandés - o al uso de una canción tradicional relativa a esa zona: "Because of the number of contextual implications here, this advertisement seems to make a high degree of impact" (Byrne 1992: 53).

Sperber y Wilson (1995: 121) ponen de manifiesto que, en numerosas ocasiones, el hecho de que una persona decida expresar un supuesto irrelevante puede ser enormemente relevante: "Relevance may be achieved by expressing irrelevant assumptions, as long as this expressive behaviour is itself relevant." En el caso que nos ocupa también podemos concluir que recurrir a un estímulo lingüístico distinto al esperado por el destinatario se debe a un comportamiento comunicativo relevante como, por otra parte, sería de esperar en cualquier acto comunicativo pagado: el publicista presenta un estímulo lingüístico en un idioma diferente que, además de actuar como una llamada de atención al destinatario, funciona como un potente activador de efectos contextuales conscientemente buscados y, a su vez, constituye una invitación para que se invierta una cierta cantidad de tiempo en procesar el enunciado del anuncio. Ya hemos comentado que Leech afirma que cuanto mayor sea el tiempo invertido en procesar un anuncio, más fácil resultará su memorización. 


\subsubsection{Las propiedades del estímulo}

En el apartado anterior hemos examinado la relación existente entre el número de implicaturas contextuales y el recuerdo de un determinado texto, hecho aplicable a distintos recursos estilísticos que caracterizan el discurso publicitario entre los que hemos incluido el uso de un idioma que no es el esperado por el destinatario. Sin embargo, a la hora de ubicar de manera correcta la utilización de la lengua inglesa en la publicidad española dentro de un ámbito comunicativo determinado, debemos recurrir a la comunicación encubierta que constituye un paso definitivo en el proceso de pérdida de responsabilidades atribuibles al emisor: mediante esta técnica, el publicista intenta informar al destinatario sin manifestar su intención informativa. De esta manera evita alterar el entorno cognitivo que comparte con su audiencia y elude referirse al propósito que persigue el acto comunicativo publicitario. En este apartado mostraremos las distintas opciones que se presentan ante un redactor a la hora de construir el texto de un anuncio comenzando con aquellas que le suponen una mayor responsabilidad - las explicaturas - y concluyendo con las que le permiten evitar cualquier exigencia no deseada: la comunicación encubierta mediante las propiedades del estímulo.

En los diferentes actos comunicativos cotidianos Sperber y Wilson distinguen entre explicaturas "an assumption obtained by the development of the logical forms encoded by an utterance" e implicaturas "assumptions which are derivable from the propositions expressed by the utterance together with the context" (1995: 182). Dentro de las implicaturas diferencian entre las que están completamente determinadas por el enunciado- implicaturas fuertes - y las que no están respaldadas por el hablante de manera tan clara: implicaturas débiles. Garrido (1999: 44) recurre al siguiente diálogo para mostrar un ejemplo de una implicatura fuerte:

(1) a. X: ¿Un cigarrillo?

b. Z: No fumo.

c. - Los que no fuman no quieren cigarrillos.

d. - Z no quiere un cigarrillo. 
El supuesto (1c) es fuerte ya que resulta necesario para que el enunciado (1b) se pueda considerar relevante. A su vez, el efecto contextual (1d) puede considerarse como una implicatura fuerte. En contraste con este ejemplo sería débil el supuesto expresado en (2a) que, en principio, responde más al entorno cognitivo del destinatario que al enunciado formulado en (1b). Un simple cambio en la expresión facial del emisor de (1b) o una mera alteración en la entonación del enunciado puede dar validez al supuesto expresado en $(2 \mathrm{a})$.

(2) a. - Los que no fuman no quieren que se fume en su presencia. b. - $\mathrm{Z}$ no quiere que $\mathrm{X}$ fume.

En muchas situaciones comunicativas habituales no se puede establecer una distinción clara entre los supuestos decididamente apoyados por el hablante y los supuestos que dependen mayormente de la interpretación del destinatario. Esta situación se complica todavía más en el caso del discurso publicitario que intencionalmente abusa de las explicaturas, tanto fuertes como débiles, debido a que, como ya hemos visto, los destinatarios tienden a cuestionar más la información explícita que la información presentada mediante implicaturas. Vestergaard y Schroder (1985: 25) analizan el siguiente titular, publicado en el Reader's Digest (Septiembre de 1977):

(3)a. - Which of these continental quilt patterns will suit your bedroom best?

De este ejemplo se derivan las siguientes implicaturas:

(3)b. - All these continental quilt patterns will suit your bedroom.

(3)c. - One of these continental quilt patterns will suit your bedroom better than the others.

En otros casos se utilizan las implicaturas con el objetivo de establecer una distinción entre el producto publicitado y otros productos del mercado: 
(4)a. - $\mathrm{X}$ is the light moisturizing cream.

- It's not greasy or sticky.

Vestergaard y Schroder (1985: 25)

La implicatura que lógicamente se deduce del ejemplo (4a) es:

(4)b. - Other moisturizing creams are greasy and sticky.

Esta estrategia del discurso publicitario plantea un grave problema para combatir desde un punto de vista legal cierta publicidad ilícita ya que en numerosas ocasiones es difícil discernir con exactitud entre las implicaturas que el emisor respalda y las que son total responsabilidad del destinatario ${ }^{118}$. Además de ayudar a eludir el cuestionamiento de la información implícita, las implicaturas contribuyen a involucrar al destinatario en el acto comunicativo publicitario evitando, al mismo tiempo, la responsabilidad del emisor frente a esas afirmaciones. Sin embargo, tanto las implicaturas fuertes como las débiles se comunican de manera ostensiva, hecho que no ocurre en los casos de comunicación encubierta:

both strong and weak implicatures are ostensively communicated, and therefore both are consistent with the principle of relevance. However weakly communicated they may be, weak implicatures comply with the requirements of overtness, which is crucial to ostensive communication. They must be distinguished from forms of covert communication, which are non-ostensive and therefore do not exhibit this overtness. (Tanaka 1994: 29)

La comunicación encubierta, ya definida en el apartado 2.7.2.2., tiene como base principal las inferencias que el destinatario produce al procesar un texto determinado y constituye para el publicista la mejor manera de evitar posibles ataques legales. Cuando el destinatario se involucra en el acto comunicativo publicitario encubierto toma una responsabilidad en la interpretación del mensaje mucho mayor que si se tratara de un acto comunicativo ostensivo. Así, el creativo publicitario se sirve de la comunicación

${ }^{118}$ Para un estudio de los diferentes procedimientos característicos de los distintos tipos de publicidad ilícita, véanse los capítulos 2.2, 2.3. y 2.4. de la tesis doctoral de Carmen Lanao Bernald titulada Aproximaciones al estudio del lenguaje publicitario en inglés: aspectos semánticos y pragmáticos. 
encubierta con dos objetivos: proponer al receptor un papel eminentemente activo en el acto comunicativo y evitar cualquier responsabilidad relativa a la interpretación del anuncio.

Si seguimos los postulados que Sperber y Wilson expresan en su teoría de la relevancia debemos concluir que el efecto del uso del inglés en la publicidad española no es lingüístico propiamente dicho ya que el efecto lingüístico comienza "when an utterance ... is manifestly chosen by the speaker for its semantic properties" (Sperber y Wilson 1986a: 178). El uso consciente de un código lingüístico distinto al que el receptor espera supone una elección por parte del emisor que intenta transmitir una información de manera encubierta a través de las propiedades del estímulo. Tanaka ilustra esta diferencia entre la comunicación lingüística propiamente dicha y la comunicación encubierta mediante las propiedades del estímulo con el siguiente ejemplo:

There are various ways in which the message that I am Japanese can be communicated. I can say, "I'm Japanese", in which case the message is conveyed by virtue of the semantic properties of my utterance. In this case, linguistic communication proper has occurred. However, when I am speaking English my accent may also convey the message that I am Japanese, without my saying so. In this case, the message is conveyed by virtue of the property of the stimulus and not via linguistic communication as such. (1994: 55)

El uso del inglés en la publicidad española también entra dentro del ámbito relativo a las propiedades del estímulo. Sin embargo, contrariamente a lo que ocurre en el ejemplo que acabamos de reproducir, se trata de un estímulo intencional que persigue el objetivo de facilitar la adhesión del destinatario al acto comunicativo publicitario con el propósito último de conseguir su persuasión.

Así, los destinatarios de ese mensaje se verán obligados a establecer las conexiones necesarias entre su conocimiento enciclopédico y la nueva información presentada utilizando un código lingüístico distinto. Este proceso es de clara naturaleza interactiva y personal. El destinatario no interpreta el mensaje en lengua inglesa buscando una asociación del producto con una connotación establecida de antemano, como parecen interpretar las teorías basadas en el modelo del código, sino que en cada situación contextual llevará a cabo su propia interpretación que dependerá tanto de la pericia del publicista a la hora de presentar la información como de su entorno cognitivo, definido en 
buena parte por sus supuestos sobre la lengua inglesa. En el análisis de nuestro corpus examinaremos con detalle los diferentes cometidos que el inglés desempeña en los anuncios publicados en la prensa española y las interpretaciones que serían más factiblemente originadas por parte de los destinatarios.

\section{2. - ESTUDIO DE NUESTRO CORPUS}

\subsection{1. - Consideraciones previas}

\subsubsection{1. - Delimitación del corpus}

El corpus que nos disponemos a analizar en este trabajo se compone de anuncios publicitarios publicados en color a una o doble página tanto en los dominicales que acompañan a la prensa española ${ }^{119}$ como en revistas de amplia difusión en España: Cambio 16, Hola, Lecturas, Tiempo, Cosmopolitan e Interviú. Todos los anuncios reproducidos en nuestro trabajo han aparecido en el período comprendido entre enero de 1997 y diciembre de $1999^{120}$.

Como ya hemos mencionado anteriormente, nuestro objetivo consiste en analizar las campañas de diversos productos publicitarios que recurren a la lengua inglesa para comunicarse con un destinatario que bien no la utiliza como código habitual o bien la desconoce por completo. Consecuentemente, no entra dentro de nuestro propósito el análisis de anuncios publicados en color en revistas españolas pero redactados en lengua inglesa con el objetivo de llegar a personas que se encuentran en España pero que han nacido en un país anglófono. Los anuncios en color dirigidos a hablantes de inglés residentes en España son muy poco frecuentes en revistas de gran difusión como las que estamos analizando, aunque sí son muy comunes en publicaciones de carácter regional: por ejemplo revistas de hostelería de cualquier zona turística española. Tampoco serán objeto de análisis los anuncios dirigidos a un destinatario al que se le solicita una

\footnotetext{
${ }^{119} \mathrm{Al}$ igual que en el análisisis estadístico llevado a cabo en el apartado 1.7.3. en esta ocasión hemos seleccionado los anuncios de las siguientes revistas dominicales: El País Semanal, Blanco y Negro, el Magazine, el Semanal y el Dominical. En esta ocasión también hemos prescindido de los anuncios que formaban parte de la promoción de novelas, películas, enciclopedias por ser de una naturaleza distinta al resto de productos comerciales que componen nuestro corpus.

${ }^{120}$ Con el propósito de mostrar la evolución sufrida por las campañas del whisky J\&B desde 1990 hasta comienzos del año 2000 hemos reproducido dos anuncios que no corresponden al período cronológico aquí mencionado (véanse las figuras 93, 94 y 95).
} 
determinada competencia lingüística en inglés que resulte necesaria para acceder a la oferta publicitada. No obstante, para diferenciar de manera clara este tipo de anuncios de los que componen nuestro corpus, mostraremos a continuación un ejemplo de cada uno de ellos.

El anuncio que reproducimos en la figura 1, aparecido el 29 de Abril de 1999 en la revista Hola, informa de la presentación de un espectáculo de baile en el Colegio de Médicos de Madrid. El hecho de que el texto del anuncio se redacte en inglés, junto a su propia naturaleza, parece responder a un deseo de comunicarse con los escasos lectores ingleses que, de manera ocasional, se puedan encontrar en el área de distribución de la revista.

El anuncio reproducido en la figura 2 publicado en la edición española de la revista Cosmopolitan (Octubre de 1998) se dirige a hablantes bilingües: inglés-español, inglés-francés. Podemos observar que su cometido es similar al de las tradicionales ofertas de empleo, normalmente publicadas en blanco y negro en la sección de negocios de los diarios, y que ya hemos analizado en el apartado 1.7.2.2.

Para llevar a cabo nuestro análisis hemos dividido los 450 anuncios que componen nuestro corpus en ocho categorías que engloban el 85 por ciento de los productos publicitados y que coinciden con los apartados que hemos diferenciado en el análisis estadístico: anuncios de cosméticos, fragancias, relojes, moda, móviles e informática, automóviles, bebidas y tabaco. Dentro de estas categorías analizaremos cada campaña de manera individualizada.

En cada uno de estos apartados llevaremos a cabo una segunda división que consideramos importante para el propósito que perseguimos en nuestro estudio: distinguiremos entre anuncios tradicionales (92 anuncios) y anuncios que siguen la técnica de la imagen de marca (294 anuncios) por tratarse de dos técnicas publicitarias muy diferentes. Como veremos en el análisis de nuestro corpus, no se trata de una división estricta y existen ciertas campañas que podrían englobarse en cualquiera de las dos categorías. Sin embargo, la elección de una de estas dos técnicas condiciona en cierta medida la función de los textos escritos en lengua inglesa.

Existen productos que tienden a utilizar exclusivamente una de las dos técnicas anteriormente mencionadas, hecho que hemos reflejado en nuestro análisis mediante el establecimiento de tres categorías: productos publicitados utilizando ambas técnicas, 
productos publicitados utilizando mayormente la estructuración tripartita tradicional y productos publicitados utilizando mayormente la técnica de la imagen de marca.

Antes de entrar en el análisis del corpus propiamente dicho abordaremos dos cuestiones preliminares. Dedicaremos un primer apartado a estudiar las diferencias más importantes que existen entre los anuncios tradicionales y los anuncios de imagen de marca. También estudiaremos en un segundo apartado los distintos elementos característicos de los anuncios tradicionales en prensa - titular, cuerpo del texto, rúbrica destacando principalmente las funciones de cada parte. En nuestro análisis del corpus, comprobaremos que en los anuncios tradicionales existe una clara relación entre la función que desempeña cada parte en la estructuración del anuncio y el uso de la lengua inglesa.

\subsubsection{Anuncios tradicionales y anuncios de imagen de marca}

En English in Advertising, Leech distingue dos tipos de anuncios publicitarios en la prensa del momento: los anuncios que él considera tradicionales y los anuncios que se basan en lo que denomina brand image. Los anuncios publicitarios tradicionales recurren al planteamiento más directo posible. Éste consiste en presentarnos las soluciones que un producto determinado nos ofrece para remediar o aminorar ciertos problemas: "The most straightforward kind of advertisement is one which describes what special need the product fulfills, or what special advantage it offers" (Leech 1966: 26). Esta técnica publicitaria se conoce en inglés con el nombre de hard sell y se caracteriza, según Cook, por utilizar la apelación directa al receptor con la finalidad explícita de persuadirle para que compre un producto concreto. El propio Cook nos da un ejemplo que considera prototípico de este tipo de anuncios ${ }^{121}$ : "My prototype of a hard sell ad involves a man in a suit, standing in front of a pile of carpets, talking loudly and directly to the camera about low cost, limited availability and guaranteed reliability" (1992: 10).

El segundo tipo de anuncios que Leech distingue adopta un método que se consideraba innovador en la década de los sesenta: la imagen de marca. En principio esta técnica, hoy en día cada vez más frecuente en la publicidad de marcas ya asentadas en el mercado, se utiliza por muy diversas razones: para publicitar productos que no pueden

${ }^{121}$ Cuando los anuncios tradicionales aparecen en prensa, suelen utilizar la división tripartita titular, cuerpo del texto, rúbrica - que estudiaremos en el apartado 3.2.1.3. 
competir en precio con artículos similares más baratos, para productos de los que no se puede destacar una cualidad materialmente objetiva que los diferencie de otros similares o artículos en los que no es fácil mostrar claramente la necesidad de su uso. En todos estos casos en vez de publicitar el producto demostrando su utilidad en una situación determinada, se suele optar por buscar la identificación anuncio-receptor mediante la imagen de marca:

(...) in recent years an alternative "brand image" approach, which aims to establish a stable market over a long period, has grown in importance. It is often more practicable to represent a product in a way which will identify it with popular desires than to persuade the public into liking it. (Leech 1966: 26)

Esta técnica publicitaria pertenece a lo que se denomina en inglés soft sell y se diferencia del planteamiento tradicional porque, en lugar de presentar una apelación directa al destinatario para intentar que éste compre el producto publicitado, opta por intentar modificar la disposición de la audiencia hacia el producto de una forma mucho más indirecta: "Soft selling relies more on mood than on exhortation, and the implication that life will be better with the product" (Cook 1992: 10). Así, en vez de presentarnos un producto en su contexto y destacar sus cualidades y su función principal, se prefiere relacionar el producto con ciertos valores, muy frecuentemente de naturaleza inmaterial, que al menos en principio son ajenos a la naturaleza del bien de consumo promocionado ${ }^{122}$.

\footnotetext{
${ }^{122}$ Williamson explica, desde una perspectiva semiótica, el proceso seguido en la creación de la imagen de marca de una fragancia haciendo referencia a una campaña que se limitaba a mostrarnos el rostro de Catherine Deneuve junto a un frasco de Chanel $\mathrm{N}^{\circ} 5$. El objetivo de este mensaje publicitario consistía en establecer una relación entre una imagen y un producto que, en principio, casi nada tenían en común. Williamson argumenta que la imagen de Catherine Deneuve "connota" elegancia, glamour, éxito, belleza, femineidad, etc. y que el receptor del anuncio se encarga de proveer la conexión entre la imagen y el propio producto haciendo que éste quede unido a los valores que la imagen representa: "Images, ideas or feelings become attached to certain products by being transferred from signs out of other systems (things or people with "images") to the products rather than originating in them. This intermediary object or person is bypassed in our perception; although it is what gives the product its meaning, we are supposed to see that meaning as already there, and we rarely notice that the correlating object and the product have no inherent similarity, but are only placed together (...). So a product and an image/emotion become linked in our minds, while the process of this linking is unconscious" (1978: 30). Jacob L. Mey también ha prestado atención a esta técnica publicitaria y en Pragmatics describe un acto pragmático que denomina co-opting y que trata del proceso de identificación "receptor - anuncio publicitario" que estamos aquí estudiando: "Another frequent pragmatic act is that of "co-opting", a technique that is especially frequent, not to say over-used, in advertising: this consists basically in seducing the "hearer" through promised identification with some prestigious environment or a set of right people: young, smart and rich" (1993: 256).
} 
Peninou, en su libro Semiótica de la Publicidad, habla de dos grandes regímenes que se reparten la comunicación publicitaria y que vienen a coincidir con lo que nosotros hemos denominado anuncios tradicionales (hard sell) y anuncios de imagen de marca (soft sell). Nos estamos refiriendo al régimen de la denotación y al régimen de la connotación :

Hay manifiestos que están visiblemente trabajados en función del mensaje de connotación. Caracterizados por el esquematismo, y hasta por la ausencia de contenido, del mensaje referencial comercial (...) y por la exuberancia de su mensaje de connotación, estos manifiestos son pobres en información sobre el producto, pero ricos en significaciones inferidas. A la inversa, otros mensajes están claramente trabajados en función de la denotación referencial. (...) Estos mensajes son necesariamente ricos en información sobre el producto y pobres en asociaciones derivadas. (1986: 78)

Por su parte, Rotzoll reflexiona acerca de las ventajas y los inconvenientes del planteamiento publicitario tradicional con respecto a los anuncios que recurren a la técnica de la imagen de marca y concluye que el grado de estructuración del anuncio está relacionado con la reacción que el receptor tiene ante el mensaje publicitario. Esta autora afirma que cuando el publicista nos presenta un mensaje estructurado las posibilidades de llevar a cabo una interpretación personal son muy limitadas:

an advertising message that is relatively structured would be one that would have a clear, unambiguous message. A structured ad would possibly feature explicitly stated product/service characteristics and expectations. It would make clear what the message is and what action we're supposed to take as a result. Given this type of message then, the posibility of distorsion via internal factors is presumably minimized. (1985: 101)

Una estructuración definida, como la característica de los anuncios tradicionales, describe el producto dentro de su contexto con lo que nos comunica un mensaje claro: se ofrece un producto (o servicio) que es necesario para solucionar un problema concreto y se nos invita a su adquisición. En estos casos se suele recurrir a la superestructura de la solución 
de problemas que facilita una percepción mas cómoda del mensaje, ayudándonos a organizar tanto el proceso de lectura como su comprensión y memorización ${ }^{123}$.

Rotzoll destaca como principal ventaja de la publicidad tradicional el hecho de que los anuncios pueden orientarse claramente hacia los receptores que van dirigidos y recurre al siguiente ejemplo: "The small newspaper ad that headlines, "Hemorroids Sufferers" is likely to attract precisely who is sought" (1985: 101). Pero este planteamiento tiene a su vez sus desventajas: un anuncio con un mensaje estructurado no permite ser malinterpretado pero al mismo tiempo limita su audiencia potencial. El planteamiento de estos anuncios es efectivo únicamente cuando logran hacer que el receptor sea consciente de que ese particular problema le afecta a él y consiguen además convencerle de que el producto publicitado puede solucionar su problema ${ }^{124}$.

Los anuncios basados en la imagen de marca se caracterizan principalmente por permitir al receptor una interpretación del propósito y del contenido del mensaje más abierta que los anuncios publicitarios tradicionales:

When the message is relatively structured, the "pattern" is already imposed and the chances for individual interpretation and patterning are diminished. In contrast, as the structure of the advertising message loosens, the pattern is more likely to be supplied by the individual in line with previous experiences, attitudes and so on. (Rotzoll 1985: 103)

\footnotetext{
${ }^{123}$ La superestructura de la solución de problemas consta de cuatro elementos siempre explícita o implícitamente presentes en los anuncios publicitarios tradicionales: presentación de la situación, surgimiento del problema, aparición de la solución (de la mano de un determinado producto) y evaluación de los resultados. Van Dijk destaca en sus diferentes trabajos la importancia del estudio de las superestructuras desde un punto de vista cognitivo. Véase Macrostructures: An Interdisciplinary Study of Global Structures in Discourse, Interaction and Cognition. $1980 \mathrm{New}$ Jersey: Lawrence Erlbaum Associates. En nuestro Trabajo de Grado titulado La organización de la información en los anuncios publicitarios en prensa: la superestructura de la solución de problemas (1997) también hemos analizado de manera pormenorizada la estructuración más característica de los anuncios en prensa.

${ }^{124}$ Para Leech, el círculo vicioso de la innovación ha llegado demasiado lejos y se ha convertido en un problema para el planteamiento tradicional de los anuncios publicitarios y así lo expresa en la siguiente cita: "The trouble with this approach in a competitive market is that it tends to lead to a vicious circle of innovation, in which inordinate claims are made for the sake of "news value". Each advertiser tries to steal a march over his competitors by publicising the most trivial change in his product as a vast improvement" (1966: 26).
} 
Rotzoll menciona como principales ventajas de los anuncios que no desarrollan una situación estructurada su potencial para atraer a una gama de receptores más amplia que los anuncios tradicionales y también que posibilitan una mayor implicación del receptor, piedra angular de la publicidad contemporánea:

Basically, by allowing room for many interpretations, the advertiser increases the possibility of attracting a wide range of customers, each of whom could potentially find something in the message that could be patterned from their own experiences, etc. Also, to the extent that the effort of patterning is that of the individual, there is potentially a greater sense of achievement, "involvement" if you will, in having "closed the message structure to some meaningful whole. (1985: 104)

\subsubsection{3.- Estructuración tripartita de los anuncios en prensa}

Atendiendo a las funciones y a la distribución del texto publicitario tradicional podemos distinguir tres partes principales: encabezamiento (headline) que normalmente va acompañado por una ilustración, cuerpo del texto (body copy), la parte más argumentativa del mensaje publicitario y la rúbrica (signature line) en la que se suele reiterar el nombre del producto o de la empresa responsable de éste seguido de un eslogan. Leech (1966: 59) menciona además dos subdivisiones secundarias: los epígrafes (subheads) y los pies de anuncio (standing details).

Los epígrafes pueden utilizarse para establecer diferentes divisiones dentro del cuerpo del texto. Por su parte, los pies de anuncio están impresos en letra pequeña y aportan información práctica sobre el producto o servicio acerca de cuestiones tales como las diferentes formas de pago, la manera de obtener más información sobre el producto, la dirección de la empresa, etc. También forman parte de estos pies de anuncio los cupones de pedido, habituales en la publicidad de respuesta directa en prensa ${ }^{125}$.

La disposición tipográfica titular - ilustración - cuerpo del texto - rúbrica es la más habitual en los anuncios publicitarios. Según datos de los análisis factoriales de Gallup and

\footnotetext{
${ }^{125}$ Para un análisis de las diferentes variaciones que se pueden encontrar en la estructuración tripartita, véase el trabajo de Lineros Estructuras lingüísticas de los discursos publicitarios en la prensa murciana. (1992)
} 
Robinson y del Starch Readership Service (Olgivy 1984: 84), ésta es la disposición existente en el $59 \%$ de los anuncios publicitarios que aparecen en prensa ${ }^{126}$.

\subsubsection{1 - Titular o encabezamiento}

El titular o encabezamiento destaca por su posición preferente en la página ${ }^{127}$. El tamaño - entre 46 y 52 puntos - y el tipo de letra en el que está impreso - negrita, mayúscula, sombra, hueca, etc. - es distinto al del resto del anuncio. Siguiendo el orden de lectura de los anuncios publicitarios propuesto por David Ogilvy (1984) nos encontramos con que el receptor percibe en primer lugar la ilustración e inmediatamente después el titular, produciéndose en este momento el primer contacto del destinatario con el texto publicitario $^{128}$. García Feliú (1984: 281) destaca que el titular cumple un doble cometido: “conquistar al lector, planteando una propuesta de su interés e impulsarle a leer el resto del anuncio."

Como hemos visto, la principal función del titular de un anuncio publicitario en prensa consiste en atraer la atención de su audiencia. Leech afirma que el titular es el elemento diferenciador por excelencia entre la estructura de un anuncio de televisión y un anuncio en prensa: "the most marked difference between the two media as regards copy and design is the lack of any television equivalent to the headline" (1966: 61). Por norma general los anuncios de televisión prescinden de los titulares debido a que el receptor comienza prestándoles cierta atención mientras que los anuncios publicados en un medio impreso

${ }^{126}$ David Ogilvy afirma preferir una distribución ligeramente distinta (Ilustración - Titular Cuerpo del texto - Rúbrica) con el objetivo de respetar el orden natural de lectura de los anuncios: "Los lectores se fijan primero en la ilustración, a continuación en el titular y por último en el texto. Por esa razón dispuse estos elementos del siguiente modo: la ilustración arriba, el titular debajo de la ilustración y el texto debajo del titular, siguiendo el orden en el que normalmente se lee, es decir de arriba a abajo. Si el titular precede a la ilustración se obliga al lector a examinar el anuncio en un orden al que no está acostumbrado. Por término medio, los titulares situados debajo de las ilustraciones obtienen un $10 \%$ más de lectura que los titulares situados encima de las ilustraciones"(1984: 89).

${ }^{127}$ Russell y Verrill (1988) establecen una distinción entre encabezamiento y eslogan, aplicando el primer término para los anuncios que llevan un cuerpo del texto y reservando el término eslogan (del gaélico Sluagh-ghairm que significa "grito de batalla") para los anuncios en los que no aparece el cuerpo del texto.

${ }^{128}$ Conejero destaca la doble función informativa y persuasiva que desempeña el diseño y los caracteres de los anuncios: "En el anuncio impreso en un medio estático, los caracteres que aparecen en el papel habrán de cumplir su misión informativa y persuasiva de forma que el lector comprenda el texto y entre en el juego de la persuasión de forma sencilla" (1995: 39). 
deben empezar por cautivar su interés: "when you advertise in magazines and newspapers, you must start by attracting the reader's attention. But in television the viewer is already attending: your problem is not to frighten her away" (Ogilvy 1984: 161).

Según los datos del estudio anteriormente citado (véase Ogilvy 1984: 161) los titulares son leídos por cinco veces más lectores que el resto del texto. Además de captar la atención del destinatario, publicistas como Ogilvy, Bassat o Bernbach entre otros aconsejan su utilización para informar del nombre del producto o de alguna característica especial de éste. Esta recomendación se sitúa dentro de la lógica pragmática publicitaria: si el titular va a ser leído por un $80 \%$ de personas que no leen el cuerpo textual del anuncio, es natural que se aconseje decir claramente el nombre del producto que se publicita o al menos destacar su característica más sobresaliente para llegar así al mayor número posible de receptores ${ }^{129}$. La segunda recomendación que Ogilvy nos da acerca del titular del anuncio es la siguiente: el titular debe prometer un beneficio a quien vaya dirigido.

\subsubsection{2.- Cuerpo del texto}

Debajo de la ilustración y del encabezamiento nos encontramos con el bloque formado por el cuerpo del texto, que destaca por su extensión y por el uso de una tipografía más ordinaria. La facilidad de lectura es uno de los imperativos que debe cumplir un buen cuerpo del texto. Para ello se recomienda el uso de tipografías ya conocidas y aceptadas por el destinatario ${ }^{130}$. La longitud de los brazos cuando sostenemos la revista o el periódico es el factor que marca el tamaño de los caracteres. Los tamaños adecuados oscilan entre los 8 y los 14 puntos. Ogilvy recomienda que si queremos que el texto se parezca al del editorial de la revista o periódico, debemos utilizar el tamaño 11 o 12.

\footnotetext{
${ }^{129}$ Aunque todos los estudiosos del fenómeno publicitario reconocen que la gran mayoría de los destinatarios de los anuncios no leen el cuerpo del texto, existen discrepancias a la hora de establecer un porcentaje. Rey (1992: 27) considera que únicamente el 5’5 por ciento de las personas que reciben un anuncio leen el cuerpo del texto.

${ }^{130}$ Las fuentes tipográficas se distinguen por el acabado de sus trazos: los que terminan en linea recta, como la Helvética, Chicago, Avant Garde, Boston, Futura Bold, Los Angeles, etc., se denominan sans serif mientras que las que abren el trazo a ambos lados al llegar al final tienen serif: Courier, New Century, Onyx, Tiffany, Mónaco o Times. Las fuentes con serif facilitan la lectura al hacer que la vista fluya con naturalidad de unos caracteres a los siguientes. Ogilvy recomienda que el anuncio se imprima con serif.
} 
Además, el cuerpo del texto es la parte del anuncio publicitario donde se exponen los argumentos persuasivos que el publicista atribuye al producto. Éstos se presentan utilizando los recursos estilísticos característicos del texto publicitario: elipsis verbal, abundancia de construcciones nominales, uso de oraciones de infinitivo independiente, sustitución de adverbios por adjetivos, creación mediante la puntuación de unidades sintácticas cortas de fácil asimilación para el destinatario, efectos rítmicos, conexiones léxicas, semánticas y gramaticales, etc. Todas ellas caracterizan y definen el discurso publicitario.

\subsubsection{3.- Rúbrica o cierre}

La rúbrica, también llamada cierre por ser el último elemento que el receptor del mensaje publicitario percibe, aparece espacialmente aislada del cuerpo del texto y, al igual que el titular, utiliza una tipografía que resalta por su tamaño y por el tipo de letra utilizado. La rúbrica ocupa siempre una ubicación privilegiada en la parte inferior del anuncio. Su posición más frecuente es la de la esquina inferior izquierda ya que, como veremos a continuación, el ojo del lector de anuncios publicitarios siempre acaba su recorrido en ese punto:

Existe un orden en la lectura de una composición visual, el ojo escudriña una superficie siguiendo un orden que favorece siempre el ángulo inferior derecho. La combinación de los referentes horizontal/vertical y el impulso perceptivo que dirige la mirada hacia la zona inferior izquierda dan como resultado un esquema de escudriñamiento, comprobado empiricamente, como se muestra en la siguiente figura:

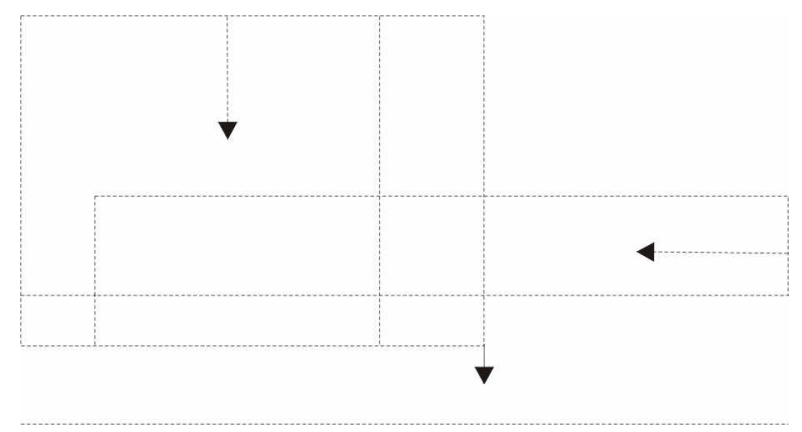

(Eguizabal 1990: 518) 
Feliú (1984:28) afirma que la rúbrica suele reiterar el nombre del producto y presentar el eslogan de la campaña: fórmula concisa y llamativa que se desea que permanezca en la memoria del consumidor y que apoya lo anteriormente dicho en el anuncio. Lanao (1992: 15) destaca que la mayor parte de los recursos fonéticos de los anuncios se agrupan en el titular y en el eslogan ya que el uso de rimas facilita la memorización de los enunciados ${ }^{131}$. Además, la rúbrica ayuda a proporcionar al anuncio publicitario una sensación de autonomía, de cohesión entre las partes, de redondez en el mensaje que facilita su comunicación. Cuanto mejor construido esté un anuncio, más sencilla resultará su transmisión.

La disposición tipográfica de las distintas partes del mensaje publicitario en la página está totalmente condicionada por las funciones que cada una de ellas cumple: el titular tiene una posición preferencial, una tipografía llamativa y un tamaño medio de diez palabras porque es el encargado de captar la atención del receptor; el cuerpo del texto tiene una mayor extensión y una tipografía ordinaria por ser la parte más argumentativa del anuncio; la rúbrica es la parte más corta, tiene una tipografía que resalta y cierra el texto por ser la encargada de presentar la conclusión del anuncio.

La estructuración tripartita que acabamos de describir, presente con mayor o menor claridad en los anuncios tradicionales, no sólo es determinante en la emisión del anuncio sino que también resulta clave en el proceso de recepción e interpretación llevado a cabo por cada destinatario. Como afirma Lineros (1992: 86) la estructuración tripartita del anuncio: "pasará por el tamiz de la memoria, la cual ayudará al receptor a crear su propia estructura mental del anuncio para su mejor almacenamiento."

${ }^{131}$ Para un estudio de las principales funciones del eslogan dentro del discurso publicitario véase Díez (1995: 62) y Ferrer (1994: 199). 


\subsection{2.- La lengua inglesa en productos anunciados utilizando ambas técnicas}

\subsubsection{1. - Anuncios de cosméticos}

En nuestro corpus aparecen 43 anuncios de cosméticos: 33 de ellos siguen la división tripartita tradicional y diez utilizan la técnica de la imagen de marca. Estée Lauder y Clinique son los productos cosméticos que tienen una mayor presencia en nuestro estudio: 34 de los 43 anuncios pertenecen a una de las dos firmas, lo que constituye un 79 por ciento del total. Su abundancia nos llevará a dedicar este apartado al análisis del uso de la lengua inglesa en las campañas de estas dos marcas de cosméticos.

En primer lugar, debemos resaltar que ambas marcas pertenecen a la misma empresa: The Estée Lauder Companies Inc., líder mundial en la producción de $\operatorname{cosméticos}^{132}$. Esta compañía ha sido fundada por Joseph y Estée Lauder en 1946 en la ciudad de Nueva York. En 1960 comienza su expansión internacional abriendo en Londres su primera oficina. Hoy en día, los productos de The Estée Lauder Companies Inc. se venden en más de cien países repartidos por los cinco continentes. Su carácter norteamericano se ve confirmado por el mayor porcentaje de ventas en su país de origen: en el año 1999 el sesenta por ciento de su producción mundial se comercializó en los Estados Unidos de América ${ }^{133}$.

Además de cosméticos, la marca Estée Lauder, buque insignia de la compañía desde su fundación, produce y comercializa fragancias: una de las más célebres de los últimos años en todo el mundo ha sido Pleasures. Por su parte, Clinique, marca fundada en 1968, también se dedica principalmente al mercado de los cosméticos. Sus anuncios se caracterizan por hacer un mayor hincapié en el cuidado de la piel: todos sus cosméticos se presentan como productos desarrollados bajo la dirección de reconocidos dermatólogos, sometidos a pruebas de alergias y sin perfume.

\footnotetext{
${ }^{132}$ The Estée Lauder Companies Inc. produce y comercializa las siguientes marcas: Estée Lauder, Aramis, Clinique, Prescriptives, Origins, M.A.C., Bobby Brown essentials, Tommy Hilfiger, Jane, Donna Karan, Aveda, La Mer, Stila y Jo Malone.

${ }^{133}$ Los datos que figuran en este párrafo aparecen en la página web de la empresa cuya dirección es www.elcompanies.com/company.html.
} 


\subsubsection{1.- Anuncios que siguen la estructuración tripartita}

Todos los anuncios de las campañas promocionales de Estée Lauder que siguen la estructuración tripartita presentan el producto publicitado de una manera muy similar. Su disposición en la página, las ilustraciones utilizadas, los diversos titulares empleados y la naturaleza de los cuerpos del texto muestran una serie de rasgos comunes que, además de proporcionar una cierta homogeneidad a la imagen del producto, facilitan la percepción del anuncio. Comenzaremos nuestro análisis de esta campaña con el estudio del titular, parte de la estructura tripartita encargada de establecer el primer contacto lingüístico con los destinatarios de este tipo de textos.

Los titulares de los anuncios de los diferentes productos de Estée Lauder son un poco más largos que los habituales ${ }^{134}$ y están compuestos por un titular principal $^{135}$ y dos subtitulares. Todos ellos comienzan con una frase en la que bien se presenta una situación problemática o bien se invita al destinatario a solucionar un problema. Posteriormente aparece la expresión "Estée Lauder crea ..." seguida del nombre del producto, que siempre aparece en lengua inglesa y que por su estilo de impresión - negrita - y el tamaño de los caracteres utilizados, es la parte del titular que más destaca. Conejero ha señalado que el discurso publicitario utiliza la negrita y el tamaño de los caracteres para resaltar del resto del texto los títulos, las frases importantes o ciertas palabras sueltas ${ }^{136}$ :

\footnotetext{
${ }^{134}$ Los titulares suelen utilizar una media de diez palabras al considerarse que esa es la extensión más adecuada para favorecer su lectura. Sin embargo, Ogilvy recomienda usar el número de palabras que se considere necesario en cada ocasión ya que ello no determina la eficacia del titular: "Según los informes de Starch, los titulares de más de diez palabras se leen menos que los más cortos. Por el contrario, cierto estudio sobre anuncios para la venta al por menor indica que los titulares de diez palabras venden más que los titulares más cortos. Conclusión: utilice titulares largos o cortos según sus necesidades, ya que ambos pueden ser eficaces" (1984: 74).

${ }^{135}$ Hemos establecido la distinción entre titular principal y subtitular atendiendo al orden en que el destinatario percibe los diferentes textos e ignorando las particulares características tipográfícas que utilizan.

${ }^{136}$ Conejero también advierte que el abuso de negrita puede hacer más difícil la lectura: "El abuso de este estilo puede suponer una cierta agresión visual, ya que añade densidad a los caracteres y, dependiendo de la fuente empleada y la longitud del texto resaltado con este estilo, la densidad añadida puede dificultar la lectura" (Conejero 1995c: 52).
} 
El texto impreso en negrita es una llamada de atención similar a la resultante de elevar el volumen de la voz en el discurso oral. La combinación entre el uso del estilo negrita, unido al de un tamaño mayor del habitual (más de 14 puntos) puede crear grandes diferencias entre dos mensajes que, en principio, fueran idénticos. (1995c: 74)

El segundo subtitular proporciona en español y en una tipografía más ordinaria cierta información sobre la función del producto publicitado, información que guarda una clara relación con el significado del término escrito en inglés. Además, el principal motivo de la ilustración en estos anuncios es el envase del producto ${ }^{137}$ donde se puede leer en lengua inglesa el nombre del cosmético publicitado junto a un breve texto que, también en inglés, define su función. Normalmente, el segundo subtitular coincide con la traducción al español del texto que en la ilustración acompaña al nombre del producto.

Veamos a continuación varios ejemplos de la estructuración característica de los titulares en la campaña de Estée Lauder:

Titular - Antes de que su piel envejezca un minuto más.

Primer subtitular - Estée Lauder crea Nutritious

Segundo subtitular - Complejo hidratante con Bio-proteínas.

Texto de la ilustración - Estée Lauder Nutritious Bio-Protein Moisture Complex

(Figura 3)

Titular - Comience hoy a proteger su piel con anti-oxidantes

Primer subtitular - Estée Lauder crea DayWear

Segundo subtitular - Complejo Super anti-oxidante

Texto de la ilustración - Estée Lauder Daywear Super Anti-oxidant Complex

(Figura 4)

Titular - Más glamour del que jamás había imaginado

Primer subtitular - Estée Lauder crea Pure Velvet

Segundo subtitular - Volumen extra para sus pestañas

Texto de la ilustración - Estée Lauder Pure Velvet Dramatic Volume Mascara

(Figura 5)

Titular - Quítese unos años de encima.

Primer subtitular - Estée Lauder crea Futurist

Segundo subtitular - Maquillaje de Base Anti-Edad con FPS 15

Texto de la ilustración - Estée Lauder Futurist Age-Resisting Makeup FPS 15

(Figura 6)

\footnotetext{
${ }^{137}$ En el apartado 1.7.3.2. ya hemos mencionado que en los anuncios de cosméticos el envase del producto suele funcionar como el principal motivo visual de la ilustración.
} 
Titular - Para pestañas finas y despobladas

Primer subtitular - Estée Lauder crea Individualist

Segundo subtitular - Máscara de pestañas voluminizadora

Texto de la ilustración - Individualist. Lash Building Mascara

(Figura 7)

Titular - De los laboratorios de Estée Lauder llega la nueva tecnología que reconstruye el aspecto de su piel desde las capas más profundas hacia la superficie.

Primer subtitular - Presentamos Eyzone Repair Gel

Segundo subtitular - Gel restaurador para el contorno de ojos.

Texto de la ilustración - Eyzone repair Gel ${ }^{138}$

(Figura 8)

Titular - Su piel nunca volverá a estar deshidratada.

Primer subtitular - Estée Lauder crea 100\% Time Release Moisturizer.

Segundo subtitular - Complejo de hidratación continua

Texto de la ilustración - Estée Lauder 100\% Time Release Moisturizer with BioMineral Water

(Figura 9)

Ciertos anuncios de Estée Lauder presentan un planteamiento ligeramente distinto: en lugar de dedicar el titular a definir una situación potencialmente problemática, optan por aportar un dato que se considera relevante para el destinatario y que da un áurea de prestigio y fiabilidad al producto. En numerosas ocasiones no se llega a establecer explícitamente una relación entre el dato mencionado y el producto publicitado. El redactor se limita a yuxtaponer ambos enunciados y el lector se encarga de proveer esa conexión:

Titular- Las últimas investigaciones desvelan las causas reales de la celulitis, y encuentran la solución.

Primer subtitular - Estée Lauder crea ThighZone

Segundo subtitular - Complejo remodelante para el cuerpo

Texto de la ilustración - Estée Lauder Thigh Zone Body Streamlining Complex

(Figura 10)

En otras ocasiones se presentan los logros del producto de una forma más explícita:

Titular - Estée Lauder reduce las líneas y arrugas hasta en un $50 \%$

Primer subtitular - Presentamos Diminish.

Segundo subtitular - Tratamiento anti-arrugas con retinol

Texto de la ilustración - Estée Lauder Diminish Anti-Wrinkle Retinol Treatment

(Figura 11)

\footnotetext{
${ }^{138}$ Tanto en este anuncio como en los anuncios que reproducimos en las figuras cuatro y once, el texto que aparece en inglés en la ilustración va acompañado de su traducción al francés.
} 
El enfoque propuesto por las campañas de cosméticos que estamos analizando en este apartado se caracteriza por resaltar el producto que se publicita incluso por encima de la marca que lo comercializa, lo que se consigue, entre muchas otras formas, presentando el envase del producto en la ilustración, repitiendo su nombre en numerosas ocasiones, explicando sus funciones específicas, recurriendo a una tipografía que destaque el producto sobre el resto del texto, etc. El hecho de que el nombre del cosmético publicitado se presente en inglés también contribuye a su realce (véase el apartado 3.1.2.1.).

Como hemos podido comprobar en los ejemplos anteriormente reproducidos, tanto el titular como la ilustración de los anuncios de Estée Lauder que siguen la estructuración tripartita recurren de manera ostensible a la lengua inglesa. Sus campañas de promoción optan por condensar la información básica del anuncio en el titular y dentro de éste el término en inglés que hace referencia al producto desempeña una función primordial.

A continuación veremos que los diferentes elementos del anuncio persiguen el objetivo de clarificar el significado del nombre comercial del producto que puede resultar más o menos opaco para el destinatario pero que se evita traducir: Thighzone, $100 \%$ Time Release Moisturizer, Pure Velvet, Individualist, Nutritious, Futurist, etc. No obstante, normalmente existe una cierta adaptación en la presentación de los nombres comerciales de los cosméticos consistente en la reducción de los términos que los componen: en el titular de los anuncios que aparecen en las revistas publicadas en inglés figura el nombre completo de los productos - Spotlight Skin Tone Perfector, Resilience Lift Face and Throat Creme, Futurist Full Treatment Lipstick SPF 15 o Minute Blush Créme Stick For Cheeks, Perfectly Clean Foaming Cleansers, etc. - mientras que en la publicidad española se opta por denominar el producto con la primera o las primeras palabras del nombre compuesto: Spotlight, Resilience, Futurist, Nutritious, etc ${ }^{139}$. En los anuncios en español el nombre completo del producto tiende a aparecer en inglés en la ilustración y traducido en el segundo subtitular.

Además, con el objetivo de mitigar cuanto antes su posible opacidad, el término en inglés se rodea ya en el mismo titular de un texto en castellano que disipa las dudas que puedan surgir acerca de las características del cosmético. La primera frase del

\footnotetext{
${ }^{139}$ Existen algunas excepciones a la tendencia general de acortar los nombres de los cosméticos: véase la figura 11 - Re-Nutriv All Day Lipstick - o la figura 9: 100 \% Time Release Moisturizer.
} 
encabezamiento crea un contexto que proporciona ciertos indicios sobre las carencias que solucionará el uso del producto. Para clarificar completamente su significado se recurre a un segundo subtitular que describe brevemente el cosmético publicitado. Por si quedara alguna duda sobre sus funciones, el cuerpo del texto se encarga de explicar en castellano y con un estilo muy accesible para el lector la información relativa al producto que ya se había anticipado en inglés en el texto que aparecía tanto en la ilustración como en el titular. Cuando se menciona el nombre del producto en el cuerpo del texto se recurre reiteradamente a la lengua inglesa.

En todos los anuncios que hemos examinado la ilustración también nos proporciona ciertos indicios acerca de la función del cosmético ya que suele estar formada por el envase del producto y por un segundo elemento visual directamente relacionado con éste que ayuda a inferir la información que aparece en inglés: en el caso de la crema hidratante $100 \%$ Time Release Moisturizer el envase se sitúa sobre un fondo ondulado y de color azul que imita al agua (figura 9), en el anuncio de la crema nutritiva Nutritious se presenta una especie de cuchara en la que se ha colocado un poco de crema (figura 3), la crema anti-oxidante Daywear va acompañada de una fotografía en tonos grises de una ciudad con una atmósfera contaminada (figura 4), etc.

En los anuncios de nuestro corpus que publicitan barras de labios se da un paso más en lo relativo a la presencia de la lengua inglesa en los titulares ya que en esta ocasión no parece necesario explicar el significado de los términos que aparecen en lengua inglesa. El titular del anuncio que reproducimos a continuación (figura 12) se limita a presentar el producto - True Lipstick - y la casa que lo comercializa en exclusiva - "Exclusivo de Estée Lauder" - porque la ilustración no deja dudas respecto a la clase de producto que está siendo publicitado, algo que sí podría ocurrir con los distintos tipos de cremas para la piel vistas anteriormente. Un segundo anuncio de barras de labios de Estée Lauder (figura 13) tampoco aclara el significado del término inglés con un subtitular, aun tratándose de un nombre comercial largo: Re-Nutriv All Day Lipstick.

La lengua inglesa también desempeña un papel muy importante en los anuncios de Clinique y su uso obedece a criterios similares a los examinados hasta este momento. En esta ocasión diferenciaremos entre los anuncios publicados a doble página y los anuncios que ocupan una sola página ya que, además de su diferente disposición, cada grupo manifiesta ciertas singularidades. 
En los anuncios a doble página (figuras 14, 15 y 16), la página izquierda ${ }^{140}$, exclusivamente dedicada a la presentación de la ilustración, se limita a reproducir en grandes dimensiones los productos publicitados donde suele aparecer nítidamente un texto en lengua inglesa que especifica la marca del producto y sus funciones:

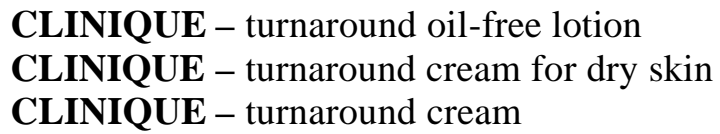

(Figura 14)

Al contrario de lo que ocurre en la campaña de Estée Lauder, estos anuncios no presentan en el titular el nombre del producto sino que formulan preguntas con el objetivo de introducir un diálogo que posteriormente se desarrollará en el cuerpo del texto:

\section{¿ Puede la piel mejorar durante la noche? (Figura 14) \\ ¿ Existe algún remedio para las líneas de expresión? (Figura 15) \\ ¿ Un labial de larga duración con brillo? (Figura 16)}

Así, la campaña de Clinique no utiliza el encabezamiento para condensar el contenido principal del anuncio, como ocurría en las campañas de Estée Lauder que acabamos de analizar. El titular cumple otras de sus tradicionales funciones: invitar al destinatario a leer el cuerpo del texto que, en esta ocasión, explica mediante una estructuración dialógica las características del producto publicitado ${ }^{141}$.

Al igual que en el caso de los anuncios de Estée Lauder, los cosméticos se presentan mediante términos ingleses: Turnaround Cream, Moisture On-Line, Moisture On-Call, Long Last Soft Shine Lipstick, etc. Las funciones de los distintos productos publicitados se aclaran en el cuerpo del texto: el anuncio reproducido en la figura 16 constituye un buen ejemplo de cómo se combina el término en inglés con su explicación en español haciendo incluso referencia a la extensión del nombre del producto.

\footnotetext{
${ }^{140}$ En la mayor parte de las publicaciones, la página izquierda es más barata que la página derecha por ser menos accesible a la vista. En Publicidad en medios impresos Beltrán y Cruces (1985) establecen el impacto del anuncio en función de su tamaño, de su presencia en una página par o impar, de su aparición en un diario o una revista, etc.

${ }^{141}$ Para un estudio del efecto del uso de los diálogos en los textos publicitarios véase el libro de Angela Goddard titulado The language of Advertising.
} 
Por su parte, los anuncios que ocupan una sola página dedican aproximadamente dos tercios de su espacio a la ilustración, que únicamente se compone de la representación de los productos anunciados sobre un fondo de color blanco ${ }^{142}$. Al igual que en todos los anuncios de cosméticos que hemos visto hasta ahora, en el envase del producto se puede leer un texto escrito en inglés:

CLINIQUE - Clarifying lotion 2

CLINIQUE - Dramatically different moisturizing lotion.

(Figura 18)

Los titulares suelen ser muy cortos con una media de cinco palabras y no recurren a la lengua inglesa: Bajo Control (figura 17), Vea los resultados (figura 18), Hola Adiós (figura 19), etc. El anuncio que aparece en la figura 20 presenta ciertas particularidades respecto a los demás anuncios de cosméticos que estamos analizando ya que es el único que explica los términos ingleses utilizados mediante una traducción que aparece entre paréntesis en el cuerpo del texto: Exceptionally Soothing Cream (Crema muy calmante) y Exceptionally Soothing Lotion (Loción muy calmante). La ilustración también presenta un elemento visual que ayuda al destinatario a interpretar la función del producto: la tirita que aparece pegada al envase constituye un indicio que, desde el primer momento, contribuye a aclarar el significado del nombre comercial del producto.

Al igual que en los anteriores anuncios, en el cuerpo del texto se utiliza el inglés para recordar el nombre del producto publicitado, normalmente seguido por una explicación de sus funciones, hecho que, como veremos más adelante, no ocurrirá con otros bienes de consumo de distinta naturaleza.

Sin embargo, los nombres de los diferentes productos no parecen fáciles de recordar: además de estar escritos en inglés, el hecho de que tengan una extensión que va en contra de todos los imperativos publicitarios hace muy difícil su memorización. Al nombre comercial de uno de los productos de Clinique, ya reproducido en la figura 18 Dramatically Different Moisturizing Lotion - podemos añadir los siguientes ejemplos de la misma marca: Stay The Day Eye Shadow, Rinse-Off Eye Makeup Solvent o Daily Eye Saver. En estos casos, el envase, que es parte importante de la ilustración, contribuye a facilitar la posterior identificación del cosmético publicitado por parte del destinatario ya

${ }^{142}$ Los anuncios de Clinique que ocupan una página siguen a rajatabla la disposición que recomienda Ogilvy anteponiendo la ilustración al titular. 
que cada clase de producto utiliza un envase distinto. Este hecho puede relacionarse con una de las conclusiones expuestas por Lutz (1983: 66) en su estudio de las estrategias que condicionan la memorización de los anuncios publicitarios: "Visual information is better recalled than verbal information". Así podemos concluir que los anuncios de cosméticos utilizan, además del nombre comercial, el diseño del envase para identificar el producto publicitado.

Por otra parte, la extensión del nombre comercial de los cosméticos también está relacionada con una particularidad propia de la lengua inglesa: los calificativos, tan frecuentes en el discurso publicitario, preceden al nombre intensificando así el producto anunciado $^{143}$. Ello da lugar al uso de grupos nominales con numerosos elementos antepuestos. Estas construcciones, habituales en la lengua inglesa, no son fáciles de formar en español. La dificultad de conseguir una traducción adecuada puede ser un elemento más que contribuya a la utilización del término inglés.

\subsubsection{2.- Anuncios que no siguen la estructuración tripartita}

Como ya hemos comentado anteriormente, en nuestro corpus aparecen más anuncios de cosméticos que siguen la estructuración tripartita tradicional que anuncios que optan por la técnica de la imagen de marca. Ello se debe a que el producto publicitado tiene un cierto carácter informativo - todo cosmético sirve para una función determinada: nutrir, hidratar, rejuvenecer, etc. - que contrasta con otros bienes de consumo que son de una naturaleza menos informativa: fragancias, bebidas y tabaco, entre otros ${ }^{144}$.

Los anuncios de cosméticos de nuestro corpus que siguen la técnica de la imagen de marca suelen presentar un titular muy corto en castellano seguido de una ilustración del envase, que ocupa la mayor parte de la página, en la que se lee un texto en lengua inglesa. En alguno de los ejemplos que presentamos a continuación, el envase va

\footnotetext{
${ }^{143}$ Leech muestra, en el siguiente ejemplo, un caso extremo del uso de grupos nominales compuestos en el inglés publicitario: "Poor-neighbourhood Charles was not, as one might have supposed, the most-difficultycausing child. Although he was learning-slow and loss-of-interest inclined, he would sit for hours mousequiet and lamb-docile when constructive-task-involved. But parent-doted-on every-whim-indulged Paul sought all-through-the day attention, often throwing middle-of-the classroom annoy-the-teacher tantrums" (1966: 137).

144 Vestergaard y Schroder (1985: 65) mencionan tres clases de productos que no recurren a la estructuración tripartita: el tabaco, las bebidas alcohólicas y los cosméticos. Los resultados del análisis de nuestro corpus nos llevan a sustituir los cosméticos por las fragancias en la categoría de productos que utilizan anuncios de carácter poco informativo.
} 
acompañado de un elemento visual que normalmente respalda el contenido lingüístico del titular.

En los anuncios de imagen de marca de Clinique podemos comprobar que el cuerpo del texto ha sido sustituido por un pie de anuncio. Éstos suelen estar impresos en un tamaño de letra menor que la utilizada en el resto de la página y su función tradicional consiste en aportar información práctica sobre el producto publicitado acerca de cuestiones tales como las diferentes formas de pago, la manera de obtener más información sobre el producto o la dirección de la empresa. En las figuras 21, 22 y 23 podemos comprobar que los pies de anuncio no se limitan a cumplir su función característica sino que se aprovechan para introducir un texto de naturaleza persuasiva dentro de un formato tradicionalmente informativo:

\section{Titular : Dos veces al día}

Texto de la ilustración Clinique clarifying lotion $\mathbf{2}$

Clinique: dramatically different moisturizing lotion.

Elemento visual: un cepillo de dientes

Pie de anuncio: Famoso porque funciona. El sistema básico CLINIQUE, de tres productos en tres pasos. Sencillo, efectivo y sistemático. Utilícelo dos veces al día, como su cepillo de dientes. Porque es la mejor forma de empezar la jornada. Fotografiado para CLINIQUE por Irving Penn.

(Figura 21)

\section{Titular: Felices cumpleaños}

Texto de la ilustración: Clinique Stop signs visible anti-aging serum

Elemento visual: Tres velas de cumpleaños

Pie de anuncio: Nuevo Stop signs. El serum antienvejecimiento de Clinique que reduce el aspecto de las arrugas y las manchas de la edad. Vamos, celébrelo. Cada vez que se mire al espejo. Clinique. Sometido a pruebas de alergia. $100 \%$ sin perfume.

(Figura 22)

\section{Titular: Traje a medida}

Texto de la ilustración: Clinique Superfit Makeup

Elemento visual: Una pincelada del producto

Pie de anuncio: Nuevo Maquillaje Superfit. Ligero, cómodo, de larga duración. Diseñado a la medida de su piel. Clinique. Sometido a pruebas de alergia. $100 \%$ sin perfume. www.clinique.com

(Figura 23)

La ilustración del producto, en la que destaca un texto en inglés, desempeña un papel primordial en los anuncios de cosméticos que siguen la técnica de la imagen de marca. Incluso puede darse el caso de que se presente ocupando casi toda la página y que el único texto del anuncio aparezca en inglés en el envase del producto: véanse las figuras 24 y 25. 
De esta forma se prescinde completamente del español, hecho que, aunque no es común en los anuncios de cosméticos, ocurre con mucha frecuencia en la publicidad de otros productos. La figura 24 muestra un envase abierto con un dispensador de gotas y la figura 25 únicamente presenta un envase sobre un fondo azul. Los textos que aparecen en la ilustración se corresponden con el nombre del producto:

Estee Lauder. Advanced Night Repair. Protective Recovery Complex.

(Figura 24)

Estee Lauder. Fruition Extra Multi-action Complex

(Figura 25)

En otras ocasiones no parece necesario recurrir al español para aclarar la función de un determinado producto de cosmética. En el anuncio reproducido en la figura 26 se representa el envase encuadrado por la montura de unas gafas con el siguiente mensaje:

CLINIQUE all about eyes

(Figura 26)

Por si surgiera alguna duda, en el margen derecho del anuncio aparece una nota con tipografía muy pequeña donde podemos leer el siguiente texto:

All about eyes. Tratamiento completo para las ojeras, bolsas y lineas de expresión del contorno de los ojos. Sometido a pruebas de alergia. 100\% Clinique. 


\subsubsection{2.- Anuncios de relojes}

En nuestro corpus aparecen 52 anuncios de relojes, 31 de los cuales utilizan la técnica de la imagen de marca mientras que 21 siguen la estructuración tripartita tradicional. Como cabría esperar, las diferentes marcas que componen el grupo Swatch, líder mundial en el mercado de relojes, tienen una presencia muy destacada en nuestro corpus: de un total de 52 anuncios, 22 pertenecen a alguna de las marcas de este grupo empresarial; nueve a Omega, ocho a Swatch, tres a Longines, uno a Rado y uno a Calvin Klein ${ }^{145}$.

La empresa Swatch - acrónimo formado a partir de los términos Swiss Watch tiene sus oficinas centrales en la ciudad suiza de Biel. Según informes de la propia compañía, sus relojes copan aproximadamente el veinticinco por ciento del mercado mundial y en 1998 alcanzaron un volumen de ventas de 3.269 millones de francos suizos. Sin embargo, a finales de los años setenta la industria relojera suiza sufrió una de las mayores crisis de su historia debido principalmente a la competitividad de las empresas japonesas, coreanas y taiwanesas en la producción de relojes digitales de cuarzo.

El aumento del volumen del mercado internacional contrastaba con el descenso de las exportaciones del país productor de relojes por excelencia. En sus informes, el grupo Swatch admite que en el período comprendido entre los años 1977 y 1983 el volumen de ventas de los relojes suizos en el extranjero se redujo en un cincuenta por ciento. Aunque los fabricantes helvéticos habían sido los pioneros en la comercialización de relojes de pulsera de cuarzo, seguir apostando por los tradicionales relojes mecánicos y analógicos parecía que les iba a relegar a un segundo plano en la industria relojera mundial. En este contexto de crisis se desarrolla el reloj que hoy en día se ha convertido en el buque insignia de la empresa - Swatch - y que lleva su nombre a pesar de ser una de las líneas más baratas de la compañía ${ }^{146}$. Comenzaremos el apartado 3.2.2.2.2. dedicando una

\footnotetext{
${ }^{145}$ Otras marcas del grupo Swatch que no aparecen en nuestro corpus son: Blancpain, Tissot, Certina, Mido, Hamilton, Pierre Balmain, Flick Flack, Lanco y Endura. Esta información figura en la página web de la empresa Swatch cuya dirección es www.swatchgroup.com

${ }^{146}$ El Grupo Swatch se forma en el año 1988. En 1984 se produce la fusión entre ASUAG y SSIH - las dos empresas relojeras más importantes de Suiza - para formar la Swiss Corporation of Microelectronics and Watchmaking Industries Limited (SMH). Cuatro años más tarde deciden cambiar el nombre de la corporación pasándo a llamarse The Swatch Group Ltd. Tanto esta información como la que figura en este párrafo aparece en la página web de la compañía: www.swatchgroup.com
} 
atención especial a la imagen de marca que ha conseguido crearse mundialmente este modelo de reloj. Previamente analizaremos diferentes campañas publicitarias que siguen la estructuración tripartita tradicional.

\subsubsection{1.- Anuncios que siguen la estructuración tripartita}

Los anuncios de relojes que siguen la estructuración tripartita utilizan en su mayoría la lengua inglesa para dar nombre a los distintos modelos presentados y para redactar la rúbrica. Éste es el caso de la campaña de Movado en la que en el cuerpo del texto aparece reiteradamente el modelo de reloj: Movado Gun Metal, Movado Mosaic Museum Watch, Movado Museum Liberty, etc. Todos los anuncios de esta campaña se cierran con la misma rúbrica que, como es característico, aparece en la esquina inferior izquierda de la página:

\section{O V A D O}

The Museum Watch

$\mathrm{S}$ w is $\mathrm{s}$

(Figura 27)

Así como los anuncios de cosméticos utilizaban la lengua inglesa para dar nombre a los diferentes productos publicitados, los anuncios de relojes también presentan sus modelos con un texto en inglés. Sin embargo, en esta ocasión, y al contrario de lo que ocurría en los anuncios de cosméticos, se hace un mayor hincapié en la marca del producto que en el modelo publicitado, hecho que se refleja en el uso de la negrita, las mayúsculas ${ }^{147}$ y el tamaño de fuente.

En los anuncios de relojes Mont Blanc que aparecen en nuestro corpus, el nombre de la empresa que oferta el producto se ubica en el lugar normalmente ocupado por el titular y la rúbrica aparece en lengua inglesa en una posición preferente de la página. El eslogan de la rúbrica hace una referencia implícita a los productos más característicos de

\footnotetext{
${ }^{147}$ En nuestro corpus podemos observar que la mayor parte de los anuncios de relojes que siguen la estructuración tripartita presentan la marca del producto en letras mayúsculas.
} 
la marca: bolígrafos y plumas. El inglés también se utiliza para recordarnos la gama de artículos que se nos ofrecen ${ }^{148}$ :

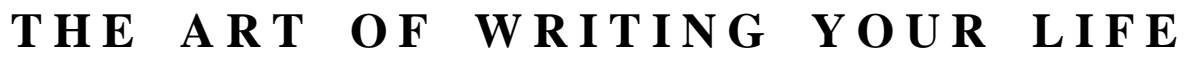 \\ Writing instruments - Watches - Leather - Jewellery - Eyewear}

(Figura 28)

Los relojes Zenith también optan por presentar la rúbrica en inglés aludiendo a su origen, a la antigüedad de la empresa que los comercializa y a una de sus principales particularidades; sólo funcionan al llevarlos:

\section{Z E N I T H}

\section{Swiss watchmakers since 1865 \\ LIFE IS IN THE MOVEMENT}

\section{(Figura 29)}

Los anuncios de los relojes suizos Rado, pertenecientes al grupo Swatch, se caracterizan por el uso de materiales tecnológicamente muy avanzados y por un diseño de naturaleza futurista. El eslogan que aparece en inglés en la rúbrica comparte ese mismo espíritu:

\section{A different world}

\section{RADO}

Switzwerland

(Figura 30)

El carácter de aventura que caracteriza una buena parte de los productos Camel Store también puede observarse en la siguiente rúbrica:

\section{CAMEL TROPHY \\ ADVENTURE WATCHES \\ ONE LIFE. LIVE IT}

(Figura 32)

El uso de la lengua inglesa se hace todavía más patente en las diferentes campañas publicitarias de los relojes TAG Heuer, producto que se dirige principalmente al

\footnotetext{
${ }^{148}$ En el anuncio de Mont Blanc que reproducimos en la figura 28 se ha optado por un término en alemán para dar nombre al modelo de reloj: Meisterstück.
} 
segmento de la gente joven, urbana y con alto poder adquisitivo ${ }^{149}$. En estas campañas, la presencia del inglés no se limita a la rúbrica sino que también se utiliza en el titular del anuncio. Desde su primera campaña, en la que aparecían deportistas tan célebres como Carl Lewis o Ayrton Senna, TAG Heuer ha optado por asociar la imagen de la empresa con ídolos mundiales del deporte profesional.

La agencia BDDP crea en 1991 para TAG Heuer una campaña publicitaria de carácter internacional donde los anuncios compartían el siguiente titular y eslogan: Don't crack under pressure. Las fotografías, en blanco y negro y de estilo periodístico, mostraban diferentes deportistas de élite sometidos a la tensión de la competición. El cuerpo del texto del anuncio especificaba el modelo de reloj publicitado y sus principales características técnicas. En esta campaña se recurría al inglés para redactar el titular y la rúbrica mientras que el cuerpo del texto se redactaba en español.

\section{Titular: DON’T CRACK UNDER PRESSURE}

Rúbrica: TAG Heuer. Swiss made since 1860

(Figura 31)

En 1995 TAG Heuer lanza una segunda campaña internacional bajo el siguiente titular que a su vez funcionaba como eslogan: Success. It's a mind game. ${ }^{150}$ Los anuncios muestran, mediante diferentes fotografías, las presiones psicológicas que sufren los deportistas de élite antes de conseguir llegar a ser los mejores: un corredor de vallas imagina que está saltando una gigantesca cuchilla de afeitar, un jinete se imagina saltando de rascacielos en rascacielos, un nadador piensa que se encuentra en una piscina llena de tiburones que le persiguen, etc.

Aunque en nuestro corpus de anuncios aparecen varios ejemplos de las dos campañas hasta ahora mencionadas, la campaña Innner Strength, ideada por la agencia BBH (Bartle,

\footnotetext{
${ }^{149}$ En el informe anual de la empresa (año 1997) se proclama abiertamente el deseo de trabajar en los productos de gama alta y suprimir la comercialización de relojes más económicos: "In addition to the Kirium introduction, TAG Heuer pursued the rationalization of its product range, aimed at establishing a clearer positioning for each of its series, renewing its offering, and discontinuing lower-priced models no longer consistent with the brand's image." Esta información aparece en la página web de la empresa cuya dirección es www.tagheuer.com/share/brands/investorrelations/1997/annual report

${ }^{150}$ Esta campaña publicitaria ha recibido numerosos premios, entre los que podemos destacar el Premio Internacional León de Plata de Cannes, la denominación de mejor anuncio de 1995 por Adweek USA y la inclusión en la lista de los diez mejores anuncios internacionales de 1995, elaborada por Time Magazine. Esta información figura en la página web de la empresa cuya dirección es www.tagheuer.com/brands
} 
Bogle, Hegarty) para TAG Heuer es la que más coincide en el tiempo con nuestro trabajo de investigación. En ella se recurre a diferentes figuras del deporte a las que se atribuye una frase siempre relativa a su coraje personal que se coloca bajo un mismo titular que, utilizando letras mayúsculas y la lengua inglesa, funciona como hilo conductor de la campaña:

Titular: INNER STRENGTH

Cuerpo del texto: SACO LAS FUERZAS DEL MIEDO. EL MIEDO A PERDER. NO RECUERDO LOS PARTIDOS QUE HE GANADO. SÓLO LOS QUE HE PERDIDO. Boris Becker

Rúbrica: TAG Heuer. The original sports watch since 1860. Swiss made

(Figura 33)

\section{Titular: INNER STRENGTH}

Cuerpo del texto: DURANTE UN GRAN PREMIO UN PILOTO PIERDE MAS DE UN LITRO DE AGUA. ES COMO UN COCHE QUEDÁNDOSE SIN CARBURANTE. AL FINAL ES LA FUERZA MENTAL LA QUE TE MANTIENE EN CARRERA. Mika Hakkinen

Rúbrica: TAG Heuer. The original sports watch since 1860. Swiss made

(Figura 34)

\section{Titular: INNER STRENGTH}

Cuerpo de texto: HE SIDO LA N 1 DURANTE LOS ÚLTIMOS CINCO AÑOS. LLEGAR A SERLO FUE TAN DURO COMO ESCALAR UNA MONTAÑA. PERO MANTENERME EN ESTE PUESTO ES COMO LEVANTARLA. Theresa Zabell

Rúbrica: TAG Heuer. The original sports watch since 1860. Swiss made

(Figura 35)

Al igual que en las anteriores campañas de TAG Heuer, el titular y la rúbrica se presentan en lengua inglesa mientras que el cuerpo del texto formado por la cita del deportista se redacta en español ${ }^{151}$. Estos breves textos tienen la función de describir su personalidad propia resaltando especialmente la forma en la que cada uno de ellos siente las emociones y los sacrificios que

\footnotetext{
${ }^{151}$ La naturaleza del cuerpo del texto hace que estos anuncios puedan considerarse como anuncios de imagen de marca. Nótese además que la rúbrica aparece en la esquina superior derecha de la página.
} 
conlleva la alta competición: su contenido incide en la idea expresada en inglés en el titular del anuncio.

Creemos conveniente concluir el análisis de los diferentes anuncios de TAG Heuer reproduciendo un párrafo del informe anual de esta compañía relativo al año 1997 donde se hace hincapié en el carácter mundial de sus campañas, hecho que, sin lugar a dudas, contribuye a propiciar la aparición de textos en lengua inglesa en la publicidad española de esta marca: "To ensure consistency in its global brand image, TAG Heuer's marketing strategy is tightly coordinated on a worldwide basis. (...) TAG Heuer enjoys a unique reputation for the innovative marketing strategy it has built and consistently implemented on a worldwide basis. ${ }^{152,}$

\subsubsection{2.- Anuncios que no siguen la estructuración tripartita}

La campaña que nos disponemos a analizar a continuación figura en numerosos manuales de marketing y publicidad como ejemplo del influjo determinante que puede tener en el éxito de un producto en el mercado la creación de una buena imagen de marca $^{153}$. Este hecho, unido al uso que los diferentes anuncios de Swatch hacen de la lengua inglesa, justifica la atención que vamos a prestar en este apartado tanto al surgimiento del producto como a las campañas que aparecen en nuestro corpus.

Dentro del contexto de crisis de la industria relojera suiza que hemos esbozado en el apartado 3.2.2.2. las empresas que posteriormente formarían el grupo Swatch seguían trabajando en un modelo de reloj que les permitiera recuperar el terreno perdido después de la aparición de los relojes digitales que procedían de los países orientales. A principios de los años ochenta desarrollan un prototipo denominado Delirium Vulgaris y que respondía a las siguientes características: fabricado con materiales sintéticos, a prueba de golpes, plano, sumergible, preciso, barato, disponible en distintos colores y susceptible de ser producido en masa. Para establecer un claro contraste entre este nuevo producto y los relojes que provenían de países orientales se opta por prestar una atención especial a su imagen externa, dotándola de un diseño muy novedoso.

152 Esta información aparece en la página web de la empresa cuya dirección es www.tagheuer.com/share/brands/investorrelations/1997/annual report

${ }^{153}$ Para un análisis de las estrategias de marketing de Swatch véase, por ejemplo, El libro rojo de las marcas (1999) de Luís Bassat. 
Una vez conseguido el producto se decide presentarlo en diciembre de 1982 con el nombre de Swatch.

Las campañas publicitarias que acompañan el lanzamiento y la consolidación del reloj comparten el mismo espíritu innovador que presenta el producto y son, en gran parte, responsables de su éxito. El hecho más destacable de las estrategias de marketing y publicidad desarrolladas por Swatch es su carácter internacional y su declarado espíritu juvenil. El diseño del producto, sus vías de distribución y el sello personal de la compañía han conseguido transmitir una imagen coherente que ha contribuido a su fructífera trayectoria, como reconocen las propias comunicaciones de la empresa:

The product's presentation is just like the product itself. "Always new, always different" - a motto that has been part of the Swatch philosophy at every level right from the start. Just as the product developers, technical experts, and designers always took on and continue to take on - new challenges, the same is true for Swatch marketing. Global campaigns and unconventional presentations help communicate the Swatch message all over the world. (Swatch Basics 1999: 3)

En consonancia con la imagen de universalidad perseguida por la empresa suiza, los anuncios de relojes Swatch que aparecen en la prensa española se caracterizan por recurrir con asiduidad al uso de la lengua inglesa. Uno de sus productos más populares ha sido el reloj extraplano que se publicitaba mediante la aparición de una modelo que posaba desnuda llevando únicamente su reloj Swatch. En la parte central del anuncio figuraba el siguiente texto:

\section{Am I naked? or am I not?}

(Figura 36)

En la rúbrica aparece en inglés el nombre de la empresa, el modelo de reloj y una frase que pone de manifiesto que se trata de un reloj extraplano:

\section{S w a t c h


El anuncio que reproducimos en la figura 36 ha sido publicado en diversas revistas de diferentes países europeos: tanto en territorios de habla inglesa como en países donde el inglés no es idioma oficial. En España, su publicación se vio acompañada por un anuncio muy similar que publicitaba el mismo modelo de reloj: en este segundo anuncio se recurría al español para redactar el texto principal y la mayor parte de la rúbrica que anteriormente aparecía en inglés. Existen otras diferencias: en el anuncio en inglés una modelo de raza negra publicita un reloj blanco mientras que en el anuncio en español, una modelo de raza blanca publicita un reloj de color negro (véanse las figuras 36 y 37).

La combinación de dos anuncios, uno completamente escrito en lengua inglesa y otro en el que la información principal figura en español, para publicitar un mismo producto es una estrategia que sólo aparece en nuestro corpus en dos ocasiones (véanse las figuras 153 y 154). Posiblemente, esta estrategia obedezca al deseo de mantener un anuncio común para los países donde se comercializa este modelo de reloj acompañado, cuando se crea necesario, por un segundo anuncio que responda a las particulares necesidades comunicativas de cada país. Excepto la colección Swatch Skin, todos los anuncios de Swatch llevan la misma rúbrica, compuesta por el nombre de la marca, la bandera suiza y el siguiente eslogan ${ }^{154}$ : Time ${ }^{155}$ is what you make of it.

Swatch tiene la particularidad de poseer una extensa gama de modelos diferentes. En 1983, año del lanzamiento de su primera colección, se diseñaron cuarenta y un relojes distintos. Un año más tarde se decide sustituir el número de referencia que identificaba cada modelo por distintos nombres, acordes con el espíritu atribuido al reloj anunciado, estrategia que, segúninformes de la compañía, ha contribuido decisivamente al éxito del

${ }^{154}$ Bassat (1993: 104) afirma que la combinación de un elemento visual - la bandera suiza de Swatch, el camello de Camel o el mono de Anís del Mono - con el nombre de la marca y un eslogan facilita que el destinatario recuerde el producto. Cook (1992) denomina slogo a la composición formada por un eslogan y un logotipo identificativo.

${ }^{155}$ Es una práctica muy común en el discurso publicitario asociar el concepto del tiempo cronológico con un determinado reloj. Nick Hayek Jr., presidente del grupo Swatch, explica el eslogan de su empresa haciendo una ingenua alusión a la concepción del tiempo de Hawkins o Einstein: "How long or short a particular span of time is perceived to be depends entirely on what goes on during that time. Time is relative. In "A brief History of Time", Stephen Hawkins, the genious physicist who is following up on Einstein's theories, states: "Time has become personal time depends on the person measuring it." For example, you can share a meal with a friend for sixty minutes, or you can be stuck in traffic at rush hour for sixty minutes - and you'd have a very different perception of time in each case. An hour is not always just an hour. Time is something personal, something we want and should use to do what we really enjoy" (Swatch Basics 1999: 2). 
producto $^{156}$. Así, en 1984 se podía adquirir el modelo Don't be too late, Nicholson o Black Magic. En nuestro corpus aparecen, entre otros, los modelos Love bite (figura 38), Time for love (figura 39), o Swatch beat. Como cabría esperar, la empresa decide prescindir de la adaptación lingüística de los términos que designan cada reloj al idioma propio de cada país y comercializa sus modelos utilizando la lengua inglesa.

Además de las diferentes colecciones que presenta cada año, Swatch también crea relojes para celebrar fechas señaladas del calendario ${ }^{157}$. Así encontramos anuncios íntegramente escritos en lengua inglesa que promueven la compra de relojes para celebrar el día de los enamorados:

\section{Texto: Valentime}

\section{Esfera: Time for love \\ Rúbrica: Swatch. \\ Time is what you make of it.}

(Figura 39)

En el anuncio del modelo de reloj creado para celebrar el día de la madre se opta por combinar el uso de la lengua inglesa con el español:

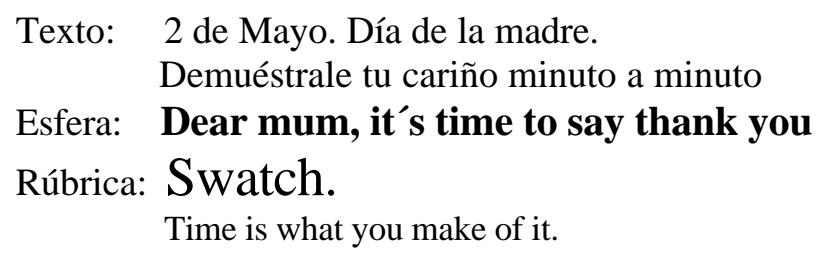

(Figura 40)

Una vez analizados diferentes anuncios de Swatch, pasamos a revisar la campaña de una marca de relojes que, aunque perteneciente a la misma empresa, se dirige a un

\footnotetext{
${ }^{156}$ Existe un club denominado The Swatch Club y supuestamente dedicado a propagar la "filosofía" de Swatch, cuyo lema es "communication among like-minded people, across the barriers of country, language and race". Sus miembros se reúnen en acontecimientos de relevancia mundial como los juegos olímpicos o las exposiciones universales y están en contacto mediante dos publicaciones patrocinadas por la empresa y redactadas en inglés: el Swatch World Journal y el Swatch News. Su popularidad, con miles de socios en todo el mundo, es una buena prueba de la fuerza de una imagen de marca exitosa.

${ }^{157}$ Además del modelo dedicado al día de la madre y a San Valentín, sabemos de la existencia de un modelo especial de Navidad y otro de Halloween. Como podemos observar, son fiestas mayormente de carácter anglosajón.
} 
sector de población bastante distinto: nos referimos a los relojes Omega. Al igual que ocurría en el caso de los relojes TAG Heuer, la campaña de Omega recurre a la presentación del producto publicitado mediante personajes famosos ${ }^{158}$. La ilustración de estos anuncios se compone de una fotografía de Pierce Brosnan, Cindy Crawford, Martina Hingis o Michael Schumacher entre otros, junto a una reproducción del modelo de reloj publicitado. En la parte superior del anuncio aparece el siguiente texto:

\section{La elección de Pierce Brosnan (Figura 41) La elección de Cindy Crawford (Figura 42)}

En la parte inferior de la página nos encontramos con una frase autógrafa del personaje que promociona el producto, frase que, independientemente de la nacionalidad del protagonista del anuncio, aparece en lengua inglesa seguida de su firma:

\section{Omega-My choice. Pierce Brosnan (Figura 41) Omega-My choice. Cindy Crawford (Figura 42)}

En esta ocasión, el uso de la lengua inglesa parece responder a un deseo de demostrar la vinculación del personaje famoso con el producto publicitado: el protagonista del anuncio no sólo escribe un mensaje de su puño y letra en su idioma sino que además lo rubrica con su firma. A la izquierda de la ilustración, con una tipografía característica de pie de página aparece un breve texto donde figura en negrita y en inglés el modelo del reloj - Seamaster GMT, Constellation, Speedmaster Automatic, etc. ciertos datos relevantes de cada reloj en particular - cronómetro automático, impermeable hasta 300 metros, etc. - y el siguiente enunciado: Omega - Swiss made since 1848. Finalmente, todos los anuncios se cierran con la misma rúbrica:

\section{O M E G A \\ The sign of excellence}

(Figuras 41 y 42)

\footnotetext{
${ }^{158}$ Bassat (1993: 105) considera que el recurso de utilizar personajes famosos para anunciar productos tiene ventajas e inconvenientes siendo clave para el éxito de la campaña una correcta elección del personaje famoso que desempeñará la promoción.
} 
Esta campaña publicitaria gira en torno a un concepto clave: la posibilidad de elección. Ello se expresa en español en el titular y en inglés en la parte inferior del anuncio. Por su parte, el eslogan que aparece en la rúbrica está directamente relacionado con el nombre comercial de la marca ya que la última letra del alfabeto griego representa las ideas de la perfección y del gozo por los retos alcanzados.

Las campañas de Raymond Weil y de Longines también se caracterizan por recurrir de manera reiterada a la lengua inglesa:

\section{LONGINES}

\section{CAPTURE the PIONEERING SPIRIT of LONGINES}

Conquest VHP. Cuarzo, cristal zafiro, sumergible a $100 \mathrm{~m}$.

LONGINES. SWISS MADE SINCE 1832

(Figura 43)

RAYMOND WEIL

GENE VE

To hear, to listen, to share, to care

\section{Celebrate the moment}

(Figura 44)

En los anuncios reproducidos en las figuras 43 y 44 podemos observar que el inglés se utiliza tanto para destacar el país de origen del producto como para redactar un texto de carácter lírico potencialmente inspirador pero poco informativo. Por su parte, se recurre al español para detallar la información de carácter más práctico: el nombre y la dirección del concesionario oficial. Todos los anuncios de relojes que componen nuestro corpus mencionan el nombre del país o ciudad originaria del producto normalmente en inglés y ocasionalmente en francés. Sin embargo, cuando se presenta información relativa a la garantía del producto, su precio o las direcciones de los distribuidores autorizados en España se adopta el idioma español.

Numerosos anuncios de relojes siguen un planteamiento de imagen de marca muy estricto que muestra una clara preeminencia del papel de la ilustración sobre el texto. Así, las figuras 45, 46 y 47 se limitan a mostrar el producto acompañado de un breve texto normalmente escrito en lengua inglesa. 


\subsubsection{3.- Anuncios de moda}

Como ya habíamos adelantado en el apartado 1.7.3.5. dentro de esta categoría hemos incluido los anuncios que publicitan tanto prendas de vestir y establecimientos de venta de ropa como calzado. Sin embargo, en esta ocasión, y a diferencia del análisis estadístico anteriormente realizado, hemos creído conveniente diferenciar los anuncios de calzado de los anuncios de ropa tanto por la propia naturaleza de los productos como por las particulares características de cada tipo de anuncios.

\subsubsection{1.- Anuncios de calzado}

En nuestro corpus figuran veintisiete anuncios de calzado: siete de ellos presentan la estructuración tripartita tradicional mientras que veinte optan por seguir la técnica basada en la imagen de marca. Aproximadamente, el setenta y cinco por ciento del total de anuncios de zapatos que aparecen en nuestro corpus han sido fabricados en España, hecho que contrasta con los dos productos que hemos analizado con anterioridad.

España ha sido tradicionalmente un país exportador de calzado y hoy en día cuenta con empresas que han conseguido llevar a cabo una notable expansión internacional de sus productos: Looky, Lottusse, Yanko, Mascaró, Sara Navarro, Panama Jack, Camper, etc. Este hecho tiene un cierto reflejo en nuestro corpus si consideramos que detrás de dos de las tres marcas de calzado que cuentan con un mayor número de anuncios se encuentran empresas españolas: el grupo empresarial dirigido por la familia Fluxá comercializa Camper y Grupp Internacional gestiona Panama Jack.

Aunque es incuestionable que la industria española del calzado siempre ha gozado de prestigio internacional en el sector, no es menos cierto que es en Gran Bretaña donde han surgido buena parte de las tendencias que hoy consideramos como tradicionales: allí aparecen, por ejemplo, los zapatos de caballero cerrados y con ojales y cordones. En los anuncios que examinaremos a continuación resulta interesante diferenciar las estrategias para publicitar el calzado originario de países anglófonos del originario de España, ya que, como veremos, ambas utilizan la lengua inglesa aunque la justificación de su uso obedece a diferentes razones. 
3.2.2.3.1.1.- Anuncios que siguen la estructuración tripartita

La presencia de la lengua inglesa es muy destacada en los anuncios de calzado que siguen la estructuración tripartita, como lo prueba el siguiente dato: de un total de siete anuncios, cuatro de ellos presentan el titular en inglés. Así la campaña de Timberland que examinamos a continuación comienza con el siguiente encabezamiento, tanto si en la ilustración se muestran unos botines de mujer como si se presentan unos zapatos de caballero:

\section{THIS IS NOT A SHOE,}

\section{THIS IS A BOOT}

(Figuras 48 y 49)

El objetivo de esta intencionada contradicción entre la información presentada visualmente en la ilustración y la información lingüística redactada en inglés en el titular consiste, en primer lugar, en atraer la atención del público al que se dirige el anuncio: el destinatario se ve obligado a tomarse un cierto tiempo para procesar y contrastar ambas informaciones si quiere resolver la incoherencia que este anuncio parece $\operatorname{presentar}^{159}$. Si en el contexto cognitivo del destinatario figura la información de que Timberland es una marca especializada en la fabricación de productos de alta montaña, éste podrá llegar más fácilmente a la resolución de la presunta incoherencia. Si el destinatario no tiene información alguna sobre la marca, el cuerpo del texto será el encargado de aclarar, ya en español, la supuesta contradicción: los zapatos Timberland que aparecen en el anuncio combinan la solidez de las botas de montaña con un diseño atractivo apto para su uso diario.

Además del titular, en esta campaña se utiliza la lengua inglesa para dar un nombre comercial a los diferentes modelos de esta marca - Corporate Weatherbuck, Debra, Air Pitch Active Air - y para redactar la siguiente nota:

TIMBERLAND - ALL TRADEMARKS OR REGISTERED TRADEMARKS OF THE TIMBERLAND COMPANY. 1998 THE TIMBERLAND COMPANY. ALL RIGHTS RESERVED.

\footnotetext{
${ }^{159} \mathrm{El}$ texto que figura en inglés en el titular puede comprenderse con una mínima competencia en lengua inglesa ya que se compone de un término transparente para los hablantes de español (Boot) y un vocablo inglés relativamente conocido (Shoe). La estructura gramatical de los enunciados utilizados tampoco puede ser más sencilla. Para un análisis del efecto del uso de textos breves y sencillos en lengua inglesa en la publicidad española véase el apartado 3.1.2.2.
} 
Por su parte, los zapatos Clarks son un buen ejemplo de un producto que presenta una campaña publicitaria basada, al menos en parte, en el origen inglés de la marca. Bajo el titular, que a su vez funciona como eslogan, de Keep Walking se presentan ilustraciones que resultan fácilmente reconocibles como británicas: en el anuncio reproducido en la figura 50 aparecen imágenes como el Tower Bridge de Londres, un autobús rojo de dos pisos, dos jóvenes en Trafalgar Square, etc. El cuerpo del texto nos invita a disfrutar del placer de caminar con los cómodos zapatos Clarks, idea central de esta campaña ya adelantada en inglés en el titular del anuncio.

Para publicitar un modelo de calzado menos urbano se utiliza el mismo encabezamiento - Keep Walking - con ilustraciones distintas pero también reconocibles como británicas: la típica señalización de los caminos campestres ingleses, una casa rural británica, una taza de té, etc. Estas ilustraciones, unidas por un borde común que imita los negativos de una fotografía o de una película de cine, presentan el ambiente natural en el que se desean ubicar los zapatos.

En ambos anuncios, los distintos modelos se presentan con un nombre inglés Burbank active air, air storm hi, lansbury, etc.- y la rúbrica nos recuerda el país de origen de los zapatos que, como podemos observar, es un elemento importante de esta campaña:

\section{clarks}

England

(Figuras 50 y 51 )

$\mathrm{Al}$ igual que ocurre con el resto de los anuncios que componen nuestro corpus, no existe una relación directa entre el hecho de que un producto sea originario de un país anglosajón y el uso de la lengua inglesa. Los anuncios de calzado que acabamos de analizar pertenecen respectivamente a una empresa americana (Timberland) y a una empresa inglesa (Clarks). No obstante, otros anuncios de zapatos recurren a la lengua inglesa sin que la elaboración del producto tenga relación alguna con países anglosajones. Así, los zapatos Bay, fabricados en Mallorca, aprovechando los efectos contextuales positivos que despierta el uso de la lengua inglesa en gran parte de los destinatarios españoles, cierran sus anuncios con la siguiente rúbrica: 


\section{Bay: Shoes for men}

(Figura 52)

Por su parte, la multinacional de origen alemán Adidas también utiliza una rúbrica en inglés para promocionar toda su gama de zapatos deportivos:

\section{Adidas. Forever Sport}

(Figura 53)

En el análisis de los anuncios de zapatos que hemos examinado hasta este momento podemos observar que cuando se anuncian bienes de consumo que no han sido fabricados por una empresa perteneciente a un país anglófono no se hace una mención explícita al país originario del producto: los anuncios de Clarks declaran abiertamente que promocionan un producto que proviene de Inglaterra y además utilizan la lengua inglesa. Por su parte, Bay y Adidas aprovechan los efectos contextuales positivos que produce el inglés en los destinatarios españoles sin hacer referencia en ningún momento al origen del producto. Esta estrategia entra dentro del dominio de la comunicación encubierta y será analizada en mayor detalle en los anuncios de tabaco, donde su uso es muy frecuente.

\subsection{2.- Anuncios que no siguen la estructuración tripartita}

Los anuncios de calzado fabricado en España que recurren al uso del inglés gozan de una mayor presencia dentro de este apartado dedicado a los productos que siguen la técnica de la imagen de marca. Este hecho se debe principalmente a dos marcas de calzado, responsables del setenta por ciento de los anuncios de esta sección, que además de dominar diversos segmentos del mercado español, compiten en mercados internacionales. Nos referimos a Panama Jack y a Camper. Antes de entrar en el estudio de sus campañas, repasaremos sucintamente la evolución de ambas empresas.

Lorenzo Fluxá, reconocido empresario del sector, crea la marca Camper en el año 1975 y desde el primer momento decide imprimir a esta nueva empresa una imagen que combine la tradición artesanal zapatera de la zona con la idea de modernidad y cosmopolitismo. El propio nombre del producto expresa esa dualidad: aunque "camper" significa en mallorquín campesino, el sufijo “-er” no deja duda, a su vez, de una clara 
filiación anglicista. En 1982 Camper abre su primera franquicia en Barcelona y diez años más tarde comienza su expansión con tiendas en los principales países europeos. Hoy en día sus productos están disponibles en Alemania, Italia, Francia, Gran Bretaña, Japón, etc. Tanto sus zapatos como sus campañas publicitarias, desarrolladas en España, han adquirido carácter internacional. La campaña "Una forma diferente de caminar" ha sido difundida por las siguientes publicaciones europeas: Max, Jalouse, Io Donna, 100 Cose, Sunday Times, FW, Arena Homme Plus, Vogue, I+D y Esquire ${ }^{160}$.

Por su parte, la marca Panama Jack se lanza en 1989 desde la costa mediterránea, una zona geográfica muy vinculada históricamente a la producción de calzado. Grupp Internacional, empresa que sirve como base para este lanzamiento, tenía como una de sus principales características el destinar toda su producción al mercado internacional. Panama Jack también comienza su andadura en diferentes países europeos, siendo Austria el primero en el que se comercializa. Una vez que el producto ha conseguido su consolidación en diversos mercados exteriores, se introduce en España. Todavía hoy en día, aproximadamente el setenta por ciento de la producción de Panama Jack se dedica a la exportación.

Joaquín Lorente ha sido el publicista responsable de la campaña de lanzamiento al mercado de los zapatos Camper. Este afamado publicista llevaba para el grupo empresarial de la familia Fluxá la cuenta de Lotusse: un zapato clásico cuya campaña publicitaria, muy conservadora, se centraba principalmente en transmitir una imagen de calidad. Sin embargo, el producto que tenía que lanzar en esta ocasión era un zapato moderno e informal dirigido a un público joven ${ }^{161}$ : “Dirigiéndose a un mercado así, era básico aceptar y adoptar una actitud de cambios gráficos en el tiempo, porque la expresión a través de las imágenes tiene un valor social y cultural definitivo" (Lorente 1986: 130).

Lorente se enorgullece del resultado de sus campañas y atribuye buena parte del éxito de Camper a la publicidad en prensa: "El mercado al que Camper se dirige ha conectado totalmente con ese estilo. En pocos años, se ha convertido en líder de su

\footnotetext{
160 Esta información figura en la página web de Camper cuya dirección es www.camper.es/empresa

${ }^{161}$ Debido al sector de población al que iba dirigido el producto, Lorente había optado por cambiar cada tres o cuatro temporadas de un estilo concreto a otro para conseguir una respuesta positiva del público joven pero manteniendo siempre la misma personalidad pública de la marca, caracterizada, sobre todo por el atrevido diseño gráfico de los anuncios que se correspondía con el diseño innovador de los distintos modelos de zapatos.
} 
segmento. Es un resultado al que han contribuido mucho las revistas, medio básico de su publicidad" (1986: 134).

Hoy en día, nadie duda de que, además de fabricar un buen producto, buena parte del valor añadido de Camper se asienta en lo que Lorente denomina su "personalidad pública", concepto que, a grandes rasgos, coincide con lo que nosotros venimos denominando imagen de marca. Al igual que ocurre con Panama Jack, el packaging, los catálogos, los distribuidores autorizados, los complementos de los zapatos, etc. (todos estos elementos se engloban en lo que en el argot publicitario se denomina Brand Print) junto con la publicidad en prensa ayudan a transmitir una determinada imagen de marca que, en este caso, hace un especial hincapié en el diseño innovador de sus productos.

El posicionamiento de Camper en el mercado coincide con el que presentan los relojes Swatch: ambos se dirigen al mismo segmento de población - jóvenes urbanos ambos tienen en el diseño del producto uno de sus principales atractivos y ambos se comercializan en distintos países. A continuación podremos observar que sus campañas también poseen muchos elementos en común: entre ellos destaca el uso que se hace de la lengua inglesa en los anuncios.

Los anuncios de Camper que aparecen en nuestro corpus han sido elaborados por una empresa creada para propagar mundialmente su imagen denominada Camper Communication Service. En ellos podemos observar que la ilustración es la principal protagonista del anuncio, relegando al texto a un lugar secundario. En la ilustración suele aparecer una fotografía del modelo de zapato publicitado que normalmente destaca por su peculiar diseño y por el uso de colores vivos (véase la figura 54). El enfoque estético que adoptan sus campañas se ve complementado por el papel que desempeña el contenido lingüístico del anuncio: se trata de textos breves que se redactan en lengua inglesa y que tienen un carácter poco informativo. Sirvan como ejemplo los siguientes textos de diferentes anuncios de Camper aparecidos en distintas publicaciones españolas. Nótese que alguno de ellos no llega si quiera a mencionar el modelo de zapato que se promociona:

$100 \%$ Camper. Camper. Try a pair

Wildlife by Camper. Camper

Traction and Stability. Pelotas by Camper

Nothing is far away. Camper
(Figura 54)

(Figura 55) 


\section{Outdoor by Camper. Casual with imagination}

\section{Kenboot. An outdoor shoe from Camper}

Al igual que ocurre en los anuncios de relojes, el uso del español se reserva para detallar la información de carácter más práctico como, por ejemplo, los establecimientos donde se puede adquirir el producto. En las campañas de Camper esta información aparece en el formato característico de los pies de página.

La imagen de marca de Panama Jack no gira en torno a la originalidad de sus diseños sino que viene marcada por una línea argumental muy distinta: el deseo de búsqueda de aventuras en diferentes entornos naturales y la fuerza de la naturaleza. Así, la naturaleza, percibida desde una perspectiva nítidamente urbana, juega un papel fundamental en sus campañas como lo prueba el anuncio que reproducimos en la figura 56:

\section{Nature wins}

Panama Jack. Natural boots.

(Figura 56)

Consecuentes con esta imagen, Panama Jack ha sido uno de los patrocinadores de multitud de proyectos como la Ruta Quetzal, la expedición Mata Rangi o las excavaciones de Atapuerca. Así, tanto la naturaleza de su calzado - botines recios de piel amarilla aterciopelada, piel hidrofugada, Gore-tex, etc.- como su imagen de marca es muy distinta a la de Camper. Sin embargo, como el segmento del mercado al que van dirigidos sus productos es el mismo, también recurren frecuentemente a la lengua inglesa.

Muchos anuncios de Panama Jack siguen un planteamiento estríctamente basado en la imagen de marca cediendo todo el protagonismo del anuncio a la ilustración del producto y sin hacer, en ningún momento, uso del español. El eslogan de estos anuncios, más largo que los habituales, reitera la asociación del producto con la naturaleza:

\section{Warm winter}

Panama Jack. The only boots and shoes made by nature and Panama Jack

(Figura 57) 
The authentic Panama Jack

The only shoes and boots made by nature and Panama Jack

(Figura 58)

\section{Spring}

Summer

98

\section{Collection.}

Panama Jack.

(Figura 59)

En otros casos se combina el uso del español y del inglés:

\section{Pruébalo.}

Panama Jack Light

(Figura 60)

“No viajo para ir a ningún sitio, sino por el placer de viajar". R.L. Stevenson.

The only shoes and boots made by nature and Panama Jack

(Figura 61)

Un primer análisis de las razones que expliquen el uso de la lengua inglesa en la publicidad de estas dos empresas españolas nos podría llevar a la siguiente conclusión: se trata de empresas que operan en diversos mercados y, como sabemos, la lengua inglesa es hoy en día la lingua franca comercial por excelencia. Sin embargo, como iremos viendo a lo largo del análisis de nuestro corpus, la verdadera explicación está más relacionada con la naturaleza del producto publicitado y el mensaje que se quiere enviar a los destinatarios target del producto que con el campo de operaciones de la empresa. 


\subsubsection{2.- Anuncios de ropa}

En nuestro corpus aparecen 38 anuncios relativos a prendas de vestir o establecimientos de venta de ropa: 4 de ellos presentan la estructuración tripartita tradicional mientras que 34 utilizan la técnica de la imagen de marca. En el caso de los anuncios de establecimientos de venta de ropa no hemos encontrado ningún ejemplo que recurra al uso de la lengua inglesa. Consecuentemente, todos los anuncios que examinaremos a continuación promocionan bien determinadas clases de tejido o bien marcas de diversas prendas de vestir.

\subsection{1.- Anuncios que siguen la estructuración tripartita}

Dos de los anuncios de ropa que aparecen en nuestro corpus y que siguen la estructuración tripartita publicitan sendos tipos de tejido patentados por distintas empresas: el Gore-tex y el Tactel. Ambos anuncios recurren a la lengua inglesa de una manera muy similar. El primero de ellos presenta tanto el titular como la rúbrica en inglés:

\section{Titular: Warning: Gore-tex may change your life.}

Rúbrica: Gore-tex fabrics. Guaranteed to keep you dry.

(Figura 62)

La ilustración y el cuerpo del texto aluden al cambio de vida al que se refiere el aviso que contiene el titular redactado en lengua inglesa: gracias al Gore-tex podemos dejar de ser "personas de interior" y volver a encontrarnos con los espacios abiertos que nos ofrece la naturaleza. Por su parte, la rúbrica, también redactada en inglés, nos recuerda que la impermeabilidad es una de las más destacadas características del producto. También en esta ocasión el cuerpo del texto hace referencia, ya en español, al contenido que la rúbrica presenta ${ }^{162}$.

\footnotetext{
${ }^{162}$ Reproducimos a continuación el cuarto párrafo del cuerpo del texto del anuncio, donde se hace referencia a la impermeabilidad característica del producto. "Probablemente Gore-tex sea el tejido más durablemente impermeable, transpirable y cortavientos que exista. Ni la lluvia ni la nieve consiguen entrar, pero el sudor sale fácilmente" (véase la figura 62).
} 
Por su parte, el segundo anuncio comienza presentando un breve titular en lengua inglesa que resulta transparente para buena parte de la población española:

\section{The Tactel effect (Figura 63)}

El cuerpo del texto menciona las principales características de las prendas confeccionadas con Tactel - bellas, prácticas, cómodas, diferentes, etc. - que supuestamente aportan ese particular efecto al que hace referencia el titular. Además, nos invita a buscar la etiqueta que identifica a estas prendas cuando vayamos de compras. En la etiqueta, que se reproduce en el anuncio a modo de rúbrica, se puede leer el eslogan de la campaña, coincidente casi en su totalidad con el titular:

\section{The tactel effect. Yes ${ }^{163} ! \quad$ (Figura 63)}

El tercer anuncio que examinaremos en este apartado ${ }^{164}$ publicita una prenda determinada, en esta ocasión la marca de corbatas Olimpo, estableciendo un paralelismo entre el Museo Británico y la mencionada marca de corbatas. El titular de anuncio dice lo siguiente:

\section{DESPUÉS DEL BRITISH MUSEUM SOMOS QUIENES MÁS IDEAS HEMOS ROBADO DE GRECIA Y ROMA}

(Figura 64)

Sobre la ilustración de las corbatas, elaboradas con un estampado de motivos griegos y romanos, podemos leer parte del texto de una noticia supuestamente publicada por el diario The Globe el veinticinco de Septiembre de 1937:

\footnotetext{
${ }^{163}$ Nótese que el Yes con el que concluye el eslogan de la campaña también aparece en grandes caracteres en la esquina superior izquierda de la ilustración.

${ }^{164}$ Hemos decidido clasificar este anuncio dentro de los que optan por el uso de la estructuración tripartita al poseer un titular, un cuerpo del texto y una rúbrica. Sin embargo, el hecho de que el texto del anuncio no describa de algún modo el producto publicitado aproxima al anuncio a la técnica de la imagen de marca, como ya habíamos comentado que ocurría en los anuncios reproducidos en la figuras 33,34 y 35 .
} 
TODAY THE BRITISH MUSEUM INAGURATES ITS NEW PAVILION DEDICATED TO GREEK AND ROMAN ART

LONDON. This afternoon London will host one of the most eagerly awaited events in recent times. After four years of remodelling and refurbishing, the new pavilion of Greek and Roman art will be oficially inaugurated at a cere-

(Figura 64)

El texto de la noticia, que se reproduce en inglés para dar una mayor autenticidad al anuncio, hace referencia al acondicionamiento del pabellón del Museo Británico dedicado al arte griego y romano. Así, se presenta una vinculación entre el producto publicitado y los diferentes diseños de las culturas clásicas a través de una institución típicamente británica haciendo uso de una sutil ironía, presente en el titular del anuncio.

El último ejemplo que examinaremos en este apartado no entra claramente dentro de la categoría de anuncios que presentan una estructuración tradicional ni tampoco dentro de los que recurren a la imagen de marca ya que, aunque hace uso de los tres elementos característicos de la estructuración tripartita, su propia extensión condiciona las funciones de cada una de las partes de la distribución tradicional. Las diecisieis páginas que ocupa y la naturaleza del contenido del cuerpo del texto hace que este anuncio presente ciertas similitudes con los publireportajes televisivos. La empresa Levi's Strauss Corporation promociona mediante esta técnica los pantalones Chinos: marca registrada distribuida por la compañía Avirex. Se trata de un tipo de pantalón supuestamente utilizado por las Fuerzas Aéreas Norteamericanas durante la primera mitad del siglo XX en las misiones llevadas a cabo en el lejano Oriente. En su primera página presenta una fotografía del modelo de pantalón publicitado enmarcado por los siguientes elementos:

\section{Titular: Chinos is Avirex}

Rúbrica: AVIREX. STANDARD US AIR CHINOS SINCE 1942

Pie de Página: The information in the following pages is true and complete to the best of our knowledge.

(Figura 65)

El cuerpo del texto ocupa la mayor parte de al menos nueve de las dieciséis páginas que componen el anuncio y está dividido en diferentes secciones, marcadas por subtitulares escritos en lengua inglesa. La función de los subencabezados que 
reproducimos a continuación consiste en definir el contenido de los apartados que forman el cuerpo del texto:

History of Chinos

Material Gabardine

The Thread

The Lining

The Fly

Friday Wear

Take Care

\section{Recommended Dealers}

Como podemos deducir de la anterior enumeración, el texto del anuncio comienza relatando el origen de este modelo de pantalón para posteriormente describir de manera muy pormenorizada sus principales características: el tipo de tejido utilizado en su confección, el hilado y el teñido, el forro, la bragueta o cremallera, las peculiaridades de los diferentes modelos, etc. La figura 66 reproduce a modo de ejemplo la penúltima sección del texto - Take Care - dedicada a presentar los cuidados básicos que debemos seguir si deseamos mantener los pantalones en condiciones óptimas. El carácter eminentemente práctico de la información y la naturaleza de su presentación, de marcado carácter didáctico y acompañada incluso por numerosas ilustraciones explicativas, hace que el uso de la lengua inglesa en los subtitulares resulte fácilmente inteligible:

\section{How to wash it \\ How to iron it \\ First Aid \\ How to keep it}

(Figura 66)

La última sección del texto, Recommended Dealers, presenta un listado de las tiendas que tienen los permisos necesarios para comercializar este producto en España. Ello se complementa con la tarjeta de Authorized Dealer que exhiben los establecimientos autorizados en lugar bien visible. 
La forma en que este anuncio combina lengua inglesa y lengua española puede encontrarse en muchos otros anuncios de Levi's. En la figura que reproducimos a continuación los diferentes subtitulares también se aprovechan para resumir, en inglés, el contenido de los diversos apartados que forman el texto:

Titular: LEVI'S 501. THE ORIGINAL SHRINK-TO-FIT JEANS

Subtitular: ADD WATER

Los Jeans Levi’s 501 Shrink-to-Fit están hechos con nuestro auténtico tejido 01, conservando su forma rígida sin lavar. Pónlos en agua y tus Jeans encojerán aproximadamente un $10 \%$ durante los tres primeros lavados.

Subtitular: KEEP COOL

Para obtener el mejor resultado de tus Jeans Levi's 501 Shrink-to-Fit, lávalos por separado. Mantén el agua fría, sin exceder los 60 grados, y deja que se encojan.

Subtitular: DRY NATURALLY

Después de lavar tus Jeans Levi's 501 Shrink-to-Fit, deja que se sequen de manera natural. La forma en que los lavas y los llevas es lo que los hace únicos.

\section{Rúbrica: LEVI'S 501. THE ORIGINAL SHRINK-TO-FIT JEANS}

(Figura 67)

El particular uso de la lengua inglesa en las campañas de Levi’s responde principalmente a dos elementos directamente relacionados con la naturaleza del producto: por una parte, el tradicional carácter americano de todos los tejanos y por extensión de éstos en particular, que además resultan ser los más vendidos, y por otra parte, los destinatarios de los anuncios, mayormente consumidores jóvenes por tratarse de ropa informal y juvenil.

El hecho de que el primer modelo de pantalón Levi’s que hemos analizado esté inspirado en los utilizados por las Fuerzas Aéreas Norteamericanas en la primera mitad del siglo XX resulta atractivo para la mayor parte de la juventud de casi todos los países occidentales, familiarizada con las gestas de las distintas divisiones que forman el ejército americano gracias a la multitud de películas que lo han presentado y todavía lo presentan como el garante de la libertad en el mundo. Como hemos visto en el apartado 1.6.3. la propia historia de España propicia que esta influencia sea mayor en nuestro país. 
3.2.2.3.2.2.- Anuncios que no utilizan la estructuración tripartita

En nuestro corpus abundan anuncios de moda tanto británicos (figura 68) como americanos (figuras 69 y 70) que publicitan sus productos recurriendo a una imagen y a un breve texto escrito en lengua inglesa:

BARBOUR. Original British Country Clothing

(Figura 68)

LEVI'S WHITE TAB LINE. 100\% ORIGINAL (Figura 69)

Stretch denim. GUESS

(Figura 70)

Sin embargo, tampoco en esta ocasión se restringe el uso de la lengua inglesa a los productos que provienen de países anglófonos y empresas como Benetton, de conocido origen italiano, recurren de manera reiterada al inglés a la hora de promocionar sus productos: sirva como ejemplo el conocido eslogan de la compañía italiana - United Colors of Benetton - que además de redactarse en inglés imita la estructura gramatical de United States of America ${ }^{165}$. En los anuncios que reproducimos a continuación se introduce una pequeña variación en el eslogan, acorde con los personajes que aparecen en la ilustración que son considerados como superestrellas - Adan y Eva (véase la figura 72) o Marilyn y Juana de Arco (véase la figura 71):

\section{United Superstars of Bennetton}

(Figuras 71 y 72)

El uso de la lengua inglesa aparece más acentuado si cabe en las campañas de Sisley, marca que también pertenece al grupo Benetton pero que presenta ropa con un diseño más innovador y atrevido: se parte de unas ilustraciones provocativas que persiguen el objetivo de crear una imagen de marca que muestre ciertos elementos de transgresión. Con ese propósito se utilizan ilustraciones ambientadas en los Estados Unidos, acompañadas de un texto escrito en lengua inglesa:

SISLEY. NYC: Twenty four hours in Manhattan

SISLEY. Living Dallas. A lone star diary.
(Figura 73)

(Figura 74)

\footnotetext{
${ }^{165}$ En nuestro corpus también aparece un anuncio de automóviles Chrysler que recurre al mismo procedimiento. En esta ocasión el eslogan que se presenta únicamente difiere en una letra del nombre del país exportador del producto: United Status of America.
} 
Por su parte, las empresas españolas del sector textil también recurren a la lengua inglesa a la hora de presentar sus productos destinados a un público joven. Saéz Merino, grupo textil y de confección con fábricas en Cheste (Valencia) y Segorbe (Castellón) dedicado fundamentalmente a la fabricación de tejanos, comercializa en el mercado español las siguientes marcas: Caroche, Caster, Cimarron, Lois y Overdale. En nuestro corpus aparecen nueve anuncios de tres marcas pertenecientes al grupo Sáez Merino: Caroche (5 anuncios), Lois ( 3 anuncios) y Bonaventure ( 1 anuncio). Sólo en uno de ellos se introduce un breve texto en español. En los demás toda la información lingüística, que por otra parte no es muy abundante por tratarse de anuncios de imagen de marca, se presenta exclusivamente en lengua inglesa. La mayor parte de los anuncios de la campaña de Caroche presentan diferentes ilustraciones que comparten el mismo eslogan:

\section{Contemporary jeans. Caroche}

(Figuras 75, 76 y 77)

Otros anuncios de Caroche presentan la siguiente expresión coloquial inglesa que, al igual que el anterior eslogan, se utiliza para sugerir ese espíritu de modernidad, originalidad o informalidad:

\section{What's up?}

Caroche

(Figura 78)

El anuncio que reproducimos en la figura 79 presenta el nombre de la marca y el eslogan a la derecha de la página y el siguiente texto en la parte izquierda del anuncio:

\section{R.I.P. STONE WASHED JEANS. \\ UP \\ DARK BLUE JEANS.}

(Figura 79)

La campaña de Lois, nombre comercial que guarda cierta similitud con el de la multinacional norteamericana Levi's, gira en torno a la idea de lo diferente: las ilustraciones de los anuncios muestran mediante la reproducción de un gesto extremadamente informal y claramente español - el equivalente inglés se hace extendiendo los dedos índice y corazón - la supuesta actitud de las personas que utilizan 
prendas de vestir Lois ante la violencia, la fuerza bruta o la xenofobia. El único texto del anuncio, escrito en inglés, resalta la idea de lo diferente (véanse las figuras 80 y 81).

Por su parte, Bonaventure Jeanswear recurre al siguiente texto:

\author{
Made in fashion, \\ in your spirit, \\ in your mind, \\ in blue \\ in love \\ Made in you \\ BONAVENTURE \\ Jeanswear
}

(Figura 82) 
3.2.2.4. - Aspectos más relevantes de la presencia de la lengua inglesa en productos publicitados utilizando ambas técnicas

Una vez analizada la presencia de la lengua inglesa en los anuncios que utilizan tanto la estructuración tripartita tradicional como la técnica de la imagen de marca, pasamos a revisar las principales conclusiones de este apartado. En los anuncios de cosméticos hemos observado que una de las razones para la introducción de términos en inglés responde al deseo de llevar a cabo una segunda llamada de atención al lector del anuncio. Después de que el anuncio haya captado la atención del destinatario mediante el titular y una ilustración atractiva y cuando el lector se encuentre inmerso en el proceso de lectura del texto, se topará con un término en lengua inglesa que además suele resaltar tipográficamente del resto del anuncio debido al uso de unos caracteres de gran tamaño y escritos en negrita. La superestructura del anuncio también contribuye al realce del nombre comercial redactado en inglés: se comienza descubriendo una situación en la que aparece un problema y cuando se presenta la solución, parte central de todo anuncio, se recurre al término inglés.

Normalmente, en las campañas de Estée Lauder los subtitulares se encargan de compensar la posible opacidad del término en inglés mientras que en los anuncios de Clinique es el cuerpo del texto quién desempeña este cometido. Además, en ambas campañas no se descarta el uso de la ilustración para contribuir a la clarificación del nombre y de la función del producto, aunque en ésta la presencia de la lengua inglesa también resulta muy destacada. Las dos campañas de cosméticos que hemos analizado presentan información redundante. Esta repetición sirve a dos objetivos: por una parte cohesiona lo expuesto en el anuncio y además corrige las posibles deficiencias comunicativas debidas al uso de la lengua inglesa en partes que resultan clave para la comprensión del anuncio.

El hecho de que los productos de cosméticos se presenten mediante un término en inglés responde a un deseo de transmitir cierta información de manera encubierta a través de las propiedades de un nuevo estímulo lingüístico: en esta ocasión lo esencial en el uso de términos en lengua inglesa no es que el significado de éstos sea comprendido por los destinatarios, que normalmente carecen de la competencia lingüística necesaria para su intelección, sino que su principal función consiste en captar su atención. Los términos en lengua inglesa pueden incluso llegar a estar vacíos de contenido para el público ya que lo 
que realmente importa es su poder de sugestión, la fuerza que imprimen al acto comunicativo y el pseudocientifismo que, en ese caso particular, parece desprenderse de su uso. Tampoco debemos olvidar los factores relativos al prestigio social comúnmente asociado al conocimiento y uso de otras lenguas, prestigio que contribuirá a favorecer la imagen del emisor del anuncio.

El grado de opacidad que presentan los nombres comerciales de los cosméticos varía considerablemente y así nos encontramos con ciertos nombres que no difieren significativamente de sus correspondientes términos en español - Futurist, Nutritious, Individualist, etc. Por otra parte, existen otros nombres comerciales de carácter mucho más opaco: Time Release Moisturizer, Resilience, Turnaround Cream, Rinse-Off Makeup Solvent, etc. En el primer caso, la interpretación satisfactoria del término en cuestión producirá un cierto placer mental en el destinatario, similar al que experimenta cuando resuelve cualquier otra presunta incoherencia del discurso publicitario. El segundo grupo de nombres comerciales parece primar una estrategia ligeramente distinta: la opacidad de los términos en inglés favorece su carácter evocativo y así el publicista espera que el destinatario acceda a las implicaturas que resulten satisfactorias para el propósito que se persigue con este acto comunicativo.

A todos los factores hasta aquí comentados, debemos añadir las restricciones legales susceptibles de aparecer a la hora de traducir una marca a distintos idiomas: desde un punto de vista jurídico, según el artículo 118 del Estatuto de la Propiedad Intelectual, una marca es "todo signo o medio material, cualquiera que sea la clase o forma, que sirva para señalar y distinguir de los similares los productos de la industria, el comercio y el trabajo" (en Rey 1996: 103). Con el objetivo de evitar problemas de copyright en los países donde se comercializa el producto, las empresas se suelen inclinar por utilizar un único término en inglés para identificar tanto sus productos como los distintos modelos de un mismo bien de consumo. Este fenómeno no es exclusivo de los anuncios de cosméticos ya que ocurre, en mayor o menor medida, en buena parte de los productos de nuestro corpus.

Tanto los anuncios de relojes que aparecen en nuestro corpus haciendo uso de la estructuración tripartita tradicional como los anuncios que siguen la técnica de la imagen de marca presentan la rúbrica en lengua inglesa: 50 anuncios de un total de 52 recurren al inglés en esta parte de su estructura. Para explicar este fenómeno debemos recordar las funciones que desempeña la rúbrica en la estructura global del anuncio. Su primera 
función consiste en actuar como cierre del anuncio, proporcionando una cierta unidad al mensaje que se desea comunicar y facilitando de esta forma su comunicación. Además, al ser el último elemento que percibe el destinatario del anuncio, se suele aprovechar para recordar la marca del producto e introducir un breve argumento o eslogan. Los anuncios de relojes que componen nuestro corpus sustituyen el tradicional argumento final característico de la rúbrica por breves textos redactados en lengua inglesa que bien indican fecha y origen de la empresa que comercializa el producto (Tag Heuer. Swiss made since 1860, Longines. Swiss Made since 1832, etc.), bien presentan un eslogan de carácter identificativo (Movado. The Museum Watch, Rado. A different world, Omega. The sign of excellence, Mont Blanc. The art of writing your life, Swatch. Time is what you make of it, etc.) o bien llevan a cabo ambas cosas (Zenith. Swiss watchmakers since 1865. Life is in the movement). El carácter poco informativo de la rúbrica contrasta con su gran capacidad para invitar al destinatario a elaborar inferencias de carácter positivo que beneficien su percepción del producto. El uso de la lengua inglesa contribuye decisivamente a este cometido.

Dentro de los anuncios de relojes nos hemos encontrado con el primer producto de nuestro corpus que declara abiertamente su empeño por planificar sus campañas a nivel mundial mostrando su preocupación por presentar la misma imagen de marca en todos los países donde se vende el producto, lo que según la propia compañía supone uno de los mayores valores de la empresa. De Mooij destaca que muchas empresas comienzan a optar por esa estrategia de creación de una marca global: "A world brand, global brand or megabrand is one which shares the same strategic principles, positioning and marketing in every market throughout the word, although the marketing mix can vary" (1991: 61). Cuando el producto publicitario se dirige a las clases más favorecidas económicamente en los diferentes países del planeta, como es el caso de los relojes TagHeuer, la lengua inglesa constituye un medio muy adecuado para crear una imagen de marca unitaria ya que ésta no resulta ajena para las clases dominantes de la mayoría de los países del mundo.

Los anuncios de calzado analizados en los apartados anteriores constituyen un buen ejemplo del uso de la lengua inglesa para publicitar productos que no proceden de un país anglosajón. Así, el recurso al inglés llevado a cabo en las campañas de Camper y Panama Jack, ambas empresas españolas que operan en mercados internacionales, parece 
responder a dos objetivos coincidentes. En primer lugar, presentan una campaña publicitaria que se puede adaptar sin cambios sustanciales a buena parte de los países donde se comercializa el producto. Para ello se presta gran atención a las ilustraciones de los anuncios, recurriendo a valores de carácter universal como la modernidad o la búsqueda de lo natural, y se reduce el componente lingüístico del anuncio, que en numerosas ocasiones se condensa en un eslogan de carácter más evocativo que informativo y que además se presenta en lengua inglesa. Cuando el producto va destinado a un público joven, con mayores conocimientos de inglés y con unas preocupaciones distintas a otros segmentos de la población a la hora de adquirir un determinado producto, se opta mayormente por la no traducción del contenido lingüístico. Así, además de facilitar la adaptación del anuncio a cada país, estas campañas dirigen su mensaje directamente al target que les concierne, restringiendo a su vez el acceso al mensaje a las personas que no forman parte de este grupo de población, más interesado por cuestiones como el precio o la durabilidad del producto que por su presunta modernidad. Los productos comercializados en diferentes países, dirigidos a un público joven y con el valor añadido de su diseño son de los que más frecuentemente recurren al uso de la lengua inglesa: véase el caso de Swatch. 


\subsection{3.- La lengua inglesa en productos publicitados utilizando la estructuración tripartita}

\subsubsection{1. - Anuncios de automóviles}

La publicidad de automóviles tiene una presencia muy importante en las revistas que hemos seleccionado, particularmente en los suplementos dominicales donde suelen aparecer, por término medio, tres anuncios de automóviles en cada número. Sin embargo, en nuestro corpus únicamente aparecen dieciseis anuncios de coches que hacen uso de la lengua inglesa: además siete de ellos pertenecen a la misma marca comercial - Smart. Como podemos observar, se trata de unos números notablemente inferiores a los de otros productos debido al peculiar carácter de ese bien de consumo que pasamos a examinar a continuación.

En principio, los automóviles son productos de clara naturaleza utilitaria, aunque en la adquisición de modelos de gama alta también existe un componente añadido de status social. Además, al tratarse de una inversión económica elevada, el consumidor suele dedicar un cierto tiempo a comparar las prestaciones de las distintas marcas y modelos que el mercado ofrece. Consecuentemente, la mayor parte de los anuncios de automóviles publicados en prensa se caracterizan por su carácter informativo y siguen la estructuración tripartita, aprovechando la ilustración para mostrar el diseño y el cuerpo del texto para aportar información relativa al producto: motor, capacidad, formas de pago, equipamiento disponible, elementos de seguridad, versiones, garantía, etc.

La presencia de la lengua inglesa es más bien escasa en los anuncios de coches y en los ejemplos que aparecen en nuestro corpus observamos que ésta se limita a presentar nuevos modelos: Land Rover Freelander, Toyota Land Cruiser, Mitsubishi Space Star, Peugeot Partner, etc. Sin embargo, y al contrario de lo que ocurre con otros productos como los cosméticos, no se trata de una tendencia predominante. Mercedes, Audi y Volvo, entre muchos otros, designan sus modelos de automóviles mediante una combinación de letras y números: Audi A3, A4, A6, A8, etc., Mercedes A140, C180, E200, etc., Volvo S40, V40, S70, V70, S80, etc. BMW y Rover tienden a utilizar números: BMW 316, 318, 320, 520, 528 , etc., Rover 25, 45, 75, etc. Seat recurre a nombres de ciudades, áreas geográficas o monumentos señalados: Arosa, Ibiza, Córdoba, Toledo, Alhambra, etc. 
Así, podemos observar que la industria automovilística utiliza muy diversos medios para dar nombre a los diferentes modelos de coches que lanza al mercado y el uso de la lengua inglesa es sólo una alternativa más. No obstante, debemos destacar que el uso del inglés sí que es muy común a la hora de diferenciar, dentro del mismo modelo de automovil, las distintas versiones tal y como muestran los siguientes ejemplos: Audi A3 Attraction, BMW 323 Compact, BMW 328 Touring, Citroën XM Break, Fiat Seicento Young, Fiat Seicento Hobby, Fiat Marea Weekend, Mercedes C 240 Classic, Opel Astra Comfort, Opel Astra Elegance, Wolkswagen Polo Trendline, Wolkswagen Polo Conceptline, Wolkswagen Golf Highline, etc.

Después de haber analizado la presencia de la lengua inglesa en los anuncios de automóviles que aparecen en nuestro corpus podemos concluir que, en términos generales, se trata de un uso relativamente escaso tanto cuantitativa como cualitivativamente. La única campaña publicitaria donde la presencia de la lengua inglesa tiene un papel destacado es la de un nuevo modelo de coche, ya anteriormente mencionado, de marcado carácter urbano: nos referimos al Smart. Comenzaremos repasando brevemente su génesis.

En el año 1994 empieza un proyecto de colaboración entre el grupo Swatch y Mercedes Benz con el objetivo de construir un vehículo compacto caracterizado por sus reducidas medidas, su bajo consumo y un diseño futurista. En octubre de 1998 este nuevo modelo comienza a aparecer en las principales ciudades europeas ya que, como hemos dicho, se trata de un coche eminentemente urbano ${ }^{166}$.

El producto se bautiza con un término inglés - Smart - que intenta reflejar su carácter ${ }^{167}$. La elección del nombre del automovil, además de ser una decisión muy probada y estudiada, constituye una parte muy importante de su imagen ${ }^{168}$. En las ciudades europeas con un alto porcentaje de habitantes con competencia lingüística en inglés, el nombre del

\footnotetext{
${ }^{166}$ Esta información figura en la página web de la compañía cuya dirección es www.smart.com/origins

${ }^{167}$ En las dos primeras acepciones que el Longman Dictionary of Comtemporary English (1987) recoge para este término se distingue entre su uso británico - neat and stylish in appearance - y el uso americano good or quick in thinking. Quizas la primera de ellas pueda hacer referencia al cuidado diseño del producto mientras que la segunda acepción aluda a su bajo consumo, quedando así cubiertas las dos características principales del modelo de automovil aquí promocionado.

${ }^{168}$ La elección del nombre de un modelo de automovil va precedida de un importante número de pruebas que, entre otras cosas, buscan que el nombre funcione bien en todos los idiomas de los paises donde se comercializa. Así, una de las razones que Seat había alegado para no utilizar la forma legal del topónimo Arosa en uno de sus modelos se referería a la similitud de la palabra en gallego con el término inglés arousal que tiene un claro tono sexual.
} 
coche se percibirá de una manera completa ya que los destinatarios del anuncio, además de notar las cualidades fonéticas de la palabra (sonoridad y monosilabismo entre otras), se percatarán de su carga semántica en la que también destaca un cierto tono informal o desenfadado. Sin embargo, la mayor parte de los destinatarios españoles pierden la carga semántica del nombre y únicamente ven en ese término una palabra de origen foráneo.

Al contrario de lo que ocurre con el uso de la lengua inglesa que se hace en los anuncios de cosméticos, el publicista no dedica ninguna parte del texto del anuncio a explicar el término en inglés que da nombre al producto. El eslogan que se utiliza en la rúbrica se limita a hacer alusión al pequeño tamaño del automovil:

\section{smart}

reduce to the max

(Figuras 83 y 84)

En el cuerpo del texto la presencia de la lengua inglesa se manifiesta mediante el uso de términos compuestos donde casi siempre aparece la palabra Smart ${ }^{169}$. Así, a la hora de promocionar los servicios que ofrece la empresa se habla de Smart Center ${ }^{170}$, financiación Smartstart, Smartmove Carsharing, Smartmove assistance, Smartmove and more. Los modelos que se comercializan son: Smart \& Pure, Smart \& Pulse, Smart \& Passion, Smart Solution 003 (véase la figura 83) y los accesorios se pueden encontrar en los centros de Smartware y Smartcare. Además hemos encontrado los siguientes anglicismos crudos: cambios softip y softouch, tracción trust-plus e inyección Commonrail. Incluso la gama de colores presenta una combinación de términos ingleses: hello yellow, true blue, phat red, bay gray, jack black, lite white.

\subsubsection{2.- Anuncios de teléfonos móviles e informática}

En nuestro corpus aparecen quince anuncios de teléfonos móviles y siete anuncios de productos relacionados con la informática. Todos ellos siguen, en mayor o menor medida, la estructuración tripartita tradicional aunque consideramos que esta tendencia ya está comenzando a variar debido a la cambiante naturaleza del discurso publicitario: cuanto éste

\footnotetext{
${ }^{169}$ En el anuncio que reproducimos en la figura 83 aparece el término Smart diez veces.

${ }^{170}$ Los anuncios de Smart utilizan la ortografía característica del inglés americano a pesar de que las dos compañías responsables del producto - Daimler Benz y Swatch - son europeas.
} 
considere que la mayoría de los destinatarios están familiarizados con las funciones del producto que se oferta, los anuncios empezarán a utilizar más profusamente la técnica de la imagen de marca.

Tanto los teléfonos móviles como los productos informáticos pertenecen al ámbito de las nuevas tecnologías y este campo se caracteriza por recibir un fuerte influjo lingüístico del inglés en lo relativo a los anglicismos que designan nuevas realidades ya provistas de una etiqueta lingüística y también en lo que se refiere al uso de mensajes escritos en lengua inglesa. No obstante, como ya hemos mencionados en el apartado 1.7.3.6., el carácter predominantemente informativo de estos anuncios hace que se combine el idioma inglés con el español.

El uso del inglés en los anuncios de móviles se restringe normalmente a la rúbrica, que contiene el nombre de la empresa junto a un breve texto en inglés que funciona como el eslogan identificativo de la compañía. Así, Nokia cierra todos los anuncios de sus productos con la siguiente rúbrica:

\section{NOKIA}

Connecting People

(Figura 85)

Por su parte, Ericsson utiliza el siguiente eslogan en una línea de móviles caracterizada por facilitar como complemento al teléfono una colección de cubiertas que reproducen diferentes obras de arte:

\section{The Art of Communication}

La empresa francesa Alcatel recurre a la lengua inglesa para presentar sus distintos modelos: Alcatel One Touch Easy, Alcatel One Touch Pocket, etc. El eslogan de la compañía, que también aparece en la rúbrica, es el siguiente:

\section{Be a touch ahead}

(Figura 87)

Como hemos indicado, la tendencia general en los anuncios de móviles es recurrir a la lengua inglesa en la rúbrica. Sin embargo existen algunas excepciones. Bosch Telecom anuncia su modelo GSM 908 con un titular que invita a los lectores a propagar las características del teléfono y que, a su vez, imita la estructura sintáctica del Just do it de la 
empresa de productos deportivos Nike, uno de los eslóganes de mayor éxito en los últimos años:

\section{JUST TELL IT (Figura 88)}

El cuerpo del texto alude a las distintas prestaciones del teléfono haciendo un especial hincapié en su reducido tamaño y peso. Bang and Olufsen, marca de productos tecnológicos de gama alta, presenta un modelo de teléfono caracterizado por su esmerado diseño bajo el siguiente titular:

\section{A life ... less ordinary}

(Figura 89)

Los productos relacionados con la informática también suelen limitar el uso del inglés a la rúbrica. Así, los anuncios de microprocesadores Intel se cierran con la siguiente rúbrica:

\section{Intel}

\section{The Computer Inside}

(Figura 90)

El eslogan de la rúbrica resume el contenido del cuerpo del texto del anuncio: dentro de cada PC hay un microprocesador que actúa como el cerebro del ordenador. Si usted compra un ordenador con el logotipo de Intel Inside en el exterior, disfrutará de un microprocesador con la tecnología más avanzada en el interior.

Los productos informáticos son proclives al uso de un eslogan de carácter identificativo escrito en lengua inglesa en la rúbrica. Las impresoras Hewlett Packard Deskjet utilizan la rúbrica:

\section{Hewlett Packard}

Expanding possibilities

(Figura 91)

World Online, empresa que comercializa diversos servicios relacionados con el acceso a internet, utiliza la siguiente rúbrica: 


\section{Freedom of Movement}

\section{World Online}

The Internet Communication Company

(Figura 92)

En esta ocasión, el titular del anuncio presenta la traducción al español del eslogan identificativo de la empresa - Libertad de Movimiento - que, como hemos visto, aparece en la rúbrica en lengua inglesa. El uso de un tipo de letra similar en ambos enunciados contribuye a facilitar esa relación. 


\subsubsection{3. - Aspectos más relevantes de la presencia de la lengua inglesa en productos publicitados utilizando la estructuración tripartita}

Ya hemos comentado a lo largo de este trabajo que la naturaleza del producto publicitado condiciona de manera notable la estrategia a seguir en su promoción. Este apartado nos ha presentado productos de naturaleza utilitaria - automóviles, ordenadores, teléfonos móviles, etc. - que tienden a publicitarse mediante textos con un cierto carácter informativo que contrasta con el componente lingüístico presente en los anuncios de otros productos - bebidas, tabaco, fragancias, etc. - de naturaleza más emotiva y menos informativa.

La naturaleza del producto condiciona tanto la estructuración del anuncio como el uso que en éste se hace de la lengua inglesa ${ }^{171}$. En cuanto a su estructuración, debemos destacar la abundancia de anuncios que recurren a la distribución clásica de la publicidad en prensa (titular - ilustración - cuerpo del texto - rúbrica) y a la superestructura de la solución de problemas (situación - problema - solución - evaluación). Respecto al uso de la lengua inglesa es preciso señalar que ésta es mucho menos frecuente que en los anuncios de imagen de marca y únicamente suele aparecer en la presentación del modelo y en la redacción de la rúbrica. En estas ocasiones, el uso de un término o enunciado en inglés está plenamente integrado dentro de un texto redactado en castellano.

En este apartado nos volvemos a encontrar con un producto en el que el target al que se dirige el anuncio condiciona, en gran medida, el empleo de la lengua inglesa. Dentro de los anuncios de automóviles, el único que apuesta decididamente por el uso del inglés es el Smart: un novedoso modelo de coche de marcado carácter urbano, con un cuidado diseño y dirigido a un público joven de poder adquisitivo alto. Al igual que ocurría en los anuncios de productos como Camper, Panama Jack o Swatch se produce una coincidencia entre el segmento del mercado al que se destina el producto y el carácter multinacional de la campaña. Ambos condicionantes explican el recurso al uso de la lengua inglesa.

\footnotetext{
${ }^{171}$ En los anuncios de productos bancarios el uso de la lengua inglesa es muy poco frecuente. Si excluimos el uso de anglicismos, más o menos integrados en el español y relativos al campo de las inversiones, sólo hemos encontrado un banco, el Citybank, que hace uso del inglés en sus eslóganes: Citybank.The city never sleeps o Citybank. Where money lives.
} 
En cuanto a los anuncios de teléfonos móviles y productos informáticos, únicamente destacar el influjo del inglés tanto en lo relativo al uso de anglicismos de carácter tecnológico, más o menos integrados en el sistema lingüístico español, como en la denominación de los productos comercializados y en la redacción de la rúbrica. En esta ocasión, mediante el uso de la lengua inglesa se pretende que el destinatario llegue a crear la siguiente inferencia: el producto anunciado posee la tecnología más puntera. Para propiciar este proceso inferencial el discurso publicitario aprovecha la relación entre lengua inglesa y tecnología, presente en el contexto cognitivo de buena parte de la población española.

El análisis de los anuncios que componen nuestro corpus muestra claramente que la rúbrica es una de las partes que recurre con mayor frecuencia al uso de la lengua inglesa: a los anuncios de teléfonos móviles y de productos informáticos debemos añadir los anuncios de relojes y calzado, además de ciertos anuncios de cosméticos y automóviles. En apartados anteriores ya hemos visto que la rúbrica funciona como cierre del anuncio, cohesionando el mensaje que se desea comunicar y contribuyendo de esa forma a favorecer un acto comunicativo satisfactorio. Además, debemos añadir que la rúbrica, al estar normalmente compuesta por un eslogan de carácter identificativo, contribuye a hacer que el nombre del producto sea más fácil de recordar.

El discurso publicitario recurre a diversas estrategias con el objetivo de posibilitar que los anuncios puedan recordarse con facilidad: presentar la información sobre el producto siguiendo la superestructura de la solución de problemas, crear analogías entre el producto y un referente conocido para el destinatario y con características que beneficien su percepción del producto, objetar a alguna opinión que forme parte del contexto cognitivo del destinatario para convencerle con una nueva argumentación, etc. En numerosas ocasiones, estas estrategias se complementan con la presentación de un eslogan que condense alguna de las principales informaciones presentes en el resto del anuncio.

En los estudios que tratan de analizar las capacidades cognitivas humanas parece existir una tendencia general a aceptar que la memoria se organiza en nuestro cerebro formando diferentes grupos de información, comúnmente designados mediante la voz inglesa chunks (véase Sperber y Wilson 1996: 531). Lutz (1983: 76) considera que, en numerosas ocasiones, las marcas, los esloganes y los logotipos que aparecen en los anuncios funcionan como fragmentos de información (chunks) fácilmente almacenables en la 
memoria y con un enorme potencial para comunicar numerosos elementos informativos, denominados bits de información. El hecho de que el discurso publicitario apueste decididamente por esa estrategia de agrupar la información presentada en diferentes grupos también nos lleva a pensar que ello incrementa la capacidad de memorización.

Así, un nombre comercial como Smart agrupa una serie de elementos informativos que aparecen en los diversos componentes del anuncio, todos ellos relacionados con el doble significado del término inglés: elegante e inteligente. Los eslóganes que suelen aparecen en la rúbrica constituyen una segunda manera de agrupar diferentes elementos de información:

Budweiser's slogan summarizes its campaign and tries to create a chunk of the brand name: "When you've said Bud, you've said it all." Similarly, many advertisers end an ad by telling the viewers that all they need think of is the brand name rather than the many attributes. MacDonald's slogan that "We do it all for you" is a way of chunking or summing up their ad campaign. (Lutz 1986: 76)

En la publicidad española existen numerosos ejemplos en los que un eslogan, redactado en español, sirve al propósito de condensar cierta información importante relativa al producto: el “¿Frío yo? Nunca” de Damart o el "Lo que hacemos lo hacemos bien" de Solac son sólo dos ejemplos de una estrategia muy común en el discurso publicitario. Sin embargo, los esloganes que se redactan en inglés parecen más preocupados por destacar la marca bajo la que se comercializa el producto que por resaltar alguna de las características específicas del bien de consumo.

Consideremos los ejemplos de rúbricas en los relojes y en los teléfonos móviles. Mientras que el cuerpo del texto describe en español alguna de las características técnicas del producto, el eslogan se dedica a diferenciar la marca de otras similares y actúa a su vez como denominador común de la presunta filosofía de las diversas campañas existentes en la prensa española: todos los modelos de teléfonos móviles lanzados por Nokia al mercado presentan el eslogan Nokia.Connecting People, eslogan que contrasta con los de sus principales competidores: Ericsson. The Art of Communication, Siemens. Be Inspired o Alcatel. Be a touch ahead. Los eslóganes presentes en los anuncios de relojes también se dedican a diferenciar las distintas marcas presentes en el mercado: Movado. The Museum Watch, Omega. The sign of Excellence, Titan. The new world watch, Zenith. Life is in the movement, Mont Blanc. The art of writing your life, etc. 


\subsection{4.- La lengua inglesa en productos que recurren a la imagen de marca}

\subsubsection{1.- Anuncios de bebidas}

Los anuncios de bebidas alcohólicas son muy frecuentes en la publicidad en prensa debido, sobre todo, a las restricciones legales existentes a la hora de publicitar en televisión productos con cierta graduación. Entre los 67 anuncios de bebidas que componen nuestro corpus sólo hemos encontrado dos ejemplos que promocionan refrescos: uno de Schweppes y uno de Pepsi. En cambio, los cuatro productos que aparecen con una mayor asiduidad son bebidas de alta graduación: whisky J\&B (13 anuncios), ginebra Beefeater (10 anuncios), vodka Absolut (8 anuncios) y whisky White Label (7 anuncios). Comenzaremos nuestro análisis con el estudio de las dos campañas de Whisky con mayor presencia en nuestro corpus y posteriormente estudiaremos los anuncios de ginebra Beefeater y de vodka Absolut.

J\&B ha sido, ya desde sus principios, una compañía de origen británico. En 1774, un comerciante de vinos italiano llamado Giacomo Justernini se instala en Londres, y junto a su socio George Johnson funda una empresa llamada Johnson and Justernini . A partir de 1779 comienza a vender whisky: durante el verano de ese mismo año aparece el primer anuncio de sus vinos y licores en el Morning Post. Uno de esos licores se publicitaba bajo el nombre Usque Beatha que en gaélico significa whisky escocés ${ }^{172}$. En 1831 Alfred Brooks compra la empresa que pasa a llamar Justernini and Brooks. Su expansión internacional comienza a producirse en los años treinta, después de la ley seca en los Estados Unidos, cuando J\&B nombra a la Paddington Corporation como su distribuidora en Norteamérica. Hasta bien entrados los años sesenta las exportaciones de J\&B no se extienden a Europa: una vez introducido el producto en el viejo continente se pasará a comercializarlo al resto del mundo.

La agencia publicitaria Young and Rubicam ha llevado a cabo las diferentes campañas de J\&B en España en el período que va desde 1990 hasta el uno de Enero de 2000. Después de una gran fusión de diferentes empresas comercializadoras de bebidas

\footnotetext{
${ }^{172}$ Esta información figura en la página web de la compañía cuya dirección es www.jbscotch.com
} 
alcoholicas, que ha dado lugar a la multinacional Diageo ${ }^{173}$, se ha tomado la decisión de rescindir el contrato con Young and Rubicam y agrupar todas las campañas de las diferentes bebidas de la nueva empresa - Smirnoff, Baileys, Tanqueray, Malibu, etc. - en la misma agencia de publicidad: J. Walter Thompson.

Las campañas que Young and Rubicam ha creado para J\&B en los últimos años han contribuido al éxito comercial de la marca que en el año 1999 fue líder de ventas en su sector en España y Europa. Desde sus primeros anuncios, publicados en 1990, hasta los anuncios que aparecen en nuestro corpus - que como sabemos pertenecen al período comprendido entre enero de 1998 y diciembre de 1999 - la imagen de J\&B ha sufrido una evolución constante y homogénea a la vez. El uso de la lengua inglesa ha sido desde el principio uno de los rasgos característicos de sus campañas y con el paso del tiempo esta presencia adquirirá progresivamente un papel más destacado.

La etiqueta del producto, donde figura un texto en lengua inglesa, es el elemento conductor de las diferentes campañas que J\&B ha puesto en marcha durante los últimos diez años. En los anuncios de principios de los años noventa (véanse las figuras 93 y 94) se combinaba la representación en color de buena parte del etiquetado con una ilustración en blanco y negro: en los anuncios a doble página ${ }^{174}$ una de éstas se dedicaba a reproducir la etiqueta del producto en la que se había recortado una de las palabras que debían figurar en ella - old, different, rare, scotch, etc. Este término aparecía superpuesto y con una silueta característica en la fotografía en blanco y negro, siempre acompañado de un breve texto en español:

OLD (Figura de castillo)

Erase una vez...

Invítame a un J\&B y déjate de cuentos

J\&B Scotch Whisky

(Figura 93)

\footnotetext{
${ }^{173}$ En 1997, Grand Metropolitan, empresa a la que pertenece J\&B, y Guinness se fusionan formando la multinacional Diageo. Las divisiones de bebidas de estas compañías pasan a llamarse United Distillers and Vintners. UDV es la compañía de vinos y licores más importante del mundo, realizando actividades comerciales en más de 200 países y comercializando las marcas internacionales líderes en la mayoría de las categorías de licores.

${ }^{174}$ En los anuncios a una página la parte superior reproduce parte del etiquetado del producto y la parte inferior reproduce la fotografía en blanco y negro.
} 
DIFFERENT (Figura de pez)

Por llevar la contraria

J\&B Scotch Whisky

(Figura 94)

LONDON (Figura de avión)

Le invité a un Whisky pero no le dije donde

J\&B Scotch Whisky

En los primeros anuncios elaborados por Young and Rubicam para J\&B, el texto en español, junto a la ilustración en blanco y negro y la silueta en la que se presenta la palabra escrita en inglés, crea el contexto en el que debe ser interpretado el mencionado término. Todos los términos que se presentan en inglés de manera aislada señalaban alguna de las características más destacadas del producto que, a su vez, figuraban en el etiquetado de la botella.

A mediados de los años noventa Young and Rubicam opta por introducir ligeros cambios en estos anuncios aunque se sigue manteniendo la imagen del producto: en las fotografías se pasa del blanco y negro al color, se sustituyen las palabras aisladas en inglés, características de los anteriores anuncios, por la casi totalidad de la etiqueta que también aquí aparece formando distintas figuras. A su lado se sitúa un texto con una cierta dosis de humor. El eslogan identificativo de la marca, que todavía hoy se sigue utilizando, comienza a aparecer en estos anuncios:

Texto: $\quad$ Eres la única que después de haber llegado hasta aquí resulta que tomas el J\&B sin hielo

Ilustración: un paisaje polar

Eslogan: J\&B. El único que es único

(Figura 95)

Los anuncios de J\&B que figuran en nuestro corpus siguen recurriendo a elementos similares: fotografía en blanco y negro, etiquetado del producto en color y en esta ocasión, dos términos en lengua inglesa que constituyen, junto al eslogan, el principal contenido lingüístico del anuncio. Sin embargo, en esta campaña aparecen ciertos cambios: se utiliza siempre la parte central de la etiqueta y en el medio de la parte seleccionada figura de manera muy destacada el nexo \& - llamado en inglés Ampersand - 
que, aunque en principio, sirve para enlazar los apellidos que forman el nombre comercial del producto, funciona en estos anuncios como vínculo de los dos términos a los que hemos hecho referencia: el primero de ellos aparece en el etiquetado y está directamente relacionado con éste mientras que el segundo hace referencia al contenido de la ilustración que normalmente poco tiene que ver con la naturaleza del producto. En esta ocasión la imagen crea el contexto que sirve de apoyo para que el destinatario del anuncio recupere el verdadero significado de los términos que figuran en inglés en el anuncio:

\section{Texto: STREET \& CREATE}

Ilustración: joven haciendo un dibujo con tiza en el asfalto

Eslogan: El único que es único

(Figura 96)

\section{Texto: DELICATE \& DIFFERENT}

Ilustración: una joven con guantes y vestido de noche sosteniendo un pico

Eslogan: El único que es único

(Figura 97)

\section{Texto: MALT \& GRAIN}

Ilustración: campo de cebada

Eslogan: El único que es único

(Figura 98)

Los anuncios de esta campaña que se han publicado en los últimos años recurren a la repetición de la primera palabra - pure - ya presente en los primeros anuncios, destacando así la supuesta pureza del producto que en esta ocasión se vincula mediante el nexo \& a un término de claro carácter evocativo. Además de los ejemplos que enumeraremos a continuación, en nuestro corpus aparecen las siguientes combinaciones: PURE \& VISION, PURE \& PASSION, PURE \& SPIRIT y PURE \& LOOK. 


\section{Texto: PURE \& ILLUSION}

Ilustración: cactus adornado con luces de navidad

Eslogan: El único que es único

(Figura 99)

\section{Texto: PURE \& DREAM}

Ilustración: una joven, la luna y el mar

Eslogan: El único que es único

(Figura 100)

\section{Texto: PURE \& CREATION}

Ilustración: una joven en un parque intentando hacer un dibujo

Eslogan: El único que es único

(Figura 101)

En la campaña de $J \& B$ que aparece en nuestro corpus, la lengua inglesa no se utiliza para dar nombre al producto ${ }^{175}$, como ocurría en los anuncios de cosméticos anteriormente analizados, sino que se emplea principalmente para destacar las cualidades más valiosas de la bebida: a principios de los noventa un texto proporcionaba el contexto cognitivo adecuado para que el acto comunicativo publicitario se llevase a cabo con éxito. Hoy en día, el uso de una ilustración que presenta un contenido directamente relacionado con los términos que figuran en inglés en el anuncio parece suficiente para que el destinatario llegue a una correcta interpretación. De esta manera, el texto en inglés gana presencia en el anuncio en detrimento del español que se reserva para el eslogan que, en esta campaña, se introduce recurriendo a una paradoja: "El Único que es Único".

White Label, whisky que ocupa la segunda posición en nuestro corpus si atendemos al número de anuncios, utiliza una estrategia muy similar a la que había utilizado J\&B a mediados de los años noventa (véanse las figuras 93 y 94): sobre una ilustración en color donde suelen figurar vasos llenos de Whisky se sitúa una composición formada por un breve texto en español y la parte central de la etiqueta del producto que,

\footnotetext{
${ }^{175}$ No obstante, el uso de la partícula "\&” refleja su carácter anglosajón.
} 
como es habitual, aparece en lengua inglesa. Al igual que ocurría en la campaña de J\&B a la que acabamos de hacer referencia, el texto en español también se caracteriza por tener un cierto tono humorístico:

Pase lo que pase esta noche, seguro que no te irás a casa con mal sabor de boca.

(Figura 102)

El $70 \%$ del cuerpo es agua. Ya está bien, ¿no?

(Figura 103)

\section{Abdominales, pesas, ensaladas, merluza hervida, agua mineral ... ¿Por qué no empiezas a cuidarte un poco?}

(Figura 104)

La información que más destaca en la parte de la etiqueta que reproduce el anuncio es el nombre del producto - White Label -, su origen - Product of Scotland - y la empresa responsable de la bebida - John Dewar \& Sons. Para resaltar el carácter escocés del producto, el fondo sobre el que se imprime el texto en español imita una tela con los tradicionales cuadros escoceses.

La campaña publicitaria de vodka Absolut ha sido objeto de multitud de trabajos de investigación, la mayor parte de los cuales se han desarrollado bajo un prisma semiótico ${ }^{176}$. Durante los últimos veinte años, esta empresa sueca ha promocionado sus productos mediante la misma campaña, que consta de dos elementos definitorios: la botella de Vodka Absolut, o en su defecto su silueta, y un breve texto formado por dos palabras: la primera de ellas es el nombre del producto, muy semejante al término inglés absolute y la segunda es un sustantivo escrito en lengua inglesa. En nuestro corpus aparecen los siguientes ejemplos: Absolut Groupies, Absolut Autumn, Absolut Artist, Absolut Summer, Absolut Perfection, Absolut Aromatherapy, Absolut Marilyn, Absolut Intelligence, Absolut Nirvana, Absolut Comic, Absolut Piercing y Absolut Profile. Esta campaña de publicidad gráfica revolucionó la publicidad de bebidas alcohólicas a principios de los años ochenta al haber suprimido por completo el tradicional eje que asociaba una imagen de mujer con el placer de la bebida, característico de la publicidad

\footnotetext{
${ }^{176}$ Sirva como ejemplo el artículo "De la retórica de la percepción a la retórica de la cultura" escrito por Göran Sonesson y publicado en las actas del Segundo congreso internacional de la Asociación de semiótica visual, celebrado en Bilbao en el año 1992.
} 
de la época, trasladando el foco de atención de la modelo publicitaria al diseño de la botella.

Geoff Hayes, creativo de la agencia TBWA, fue a principios de los ochenta el autor del primer anuncio de la campaña - Absolut Perfection -, anuncio que todavía hoy en día podemos encontrar en algunas revistas y que también aparece en nuestro corpus (véase la figura 105). Se cuenta que al ver el anuncio, Andy Warhol, creador del pop-art, quedó prendado por el diseño de la botella y pidió que le permitieran pintarla para realizar un segundo anuncio. De esta forma comenzó una campaña que ya ha sobrepasado los tres mil anuncios, siempre manteniendo la misma idea.

Tanto el texto que aparece en la botella como los dos términos que acompañan a la ilustración recurren a la lengua inglesa. Existe además una especie de juego entre el segundo término en inglés y la ilustración: cuando éste hace referencia al verano Absolut Summer - la silueta de la botella se presenta en forma de piscina (véase la figura 106), cuando se hace referencia al otoño - Absolut Autumn - el viento se lleva las palabras que componen la etiqueta del producto (véase la figura 107), cuando hace referencia al mundo del comic - Absolut Comic - el texto que aparece en la botella se presenta en un "bocadillo" (véase la figura 108), cuando se hace referencia a Marilyn Monroe - Absolut Marilyn - la botella se sitúa sobre una rejilla de ventilación y su etiqueta se levanta a modo de falda (véase la figura 109).

Además, en todas las ilustraciones se puede leer claramente el siguiente texto en lengua inglesa que repasa las principales características del producto promocionado:

ABSOLUT VODKA. Country of Sweden. This superb vodka was distilled from grain
grown in the rich fields of southern Sweden. It has been produced at the famous old
distilleries near Ahus in accordance with more than 400 years of Swedish tradition.
Vodka has been sold under the name of Absolut since 1879 . (Figuras 105-109)

La campaña de Beefeater es una de las más destacadas de nuestro corpus tanto por su presencia cuantitativa como por su particular uso de la lengua inglesa. Sus anuncios constan de tres elementos principales: una ilustración, la etiqueta del producto y un breve texto en lengua inglesa. La ilustración, rica en colorido, presenta a diferentes jóvenes sobre fondos formados por objetos, nubes, flores, peces, agua, etc. Por su parte, el breve texto en lengua inglesa, que figura en una tipografía destacada en la parte superior del 
anuncio, se combina con el nombre y la etiqueta del producto de una manera muy original que explicaremos a continuación.

Todos los textos que forman parte de esta campaña comienzan con el término inglés $b e$, que es la parte del anuncio que más destaca por su posición en la página y por el tamaño de sus caracteres. El tipo de letra utilizado (mayúscula de color rojo) establece una clara relación con el nombre del producto, que también comienza por be, y además contrasta con el resto del enunciado. El término be, imperativo en inglés, va seguido por un atributo que alude a diferentes características personales de naturaleza positiva: natural, good, authentic, fresh, divine, a dreamer, free, yourself, pure, etc.

Normalmente, el texto y la etiqueta del producto figuran en la misma posición preferente de la página. Cuando ello ocurre (véanse los ejemplos que van desde la figura 110 a la 116) se aprovecha el mayor tamaño del término be para unir el texto en inglés con la etiqueta del producto:

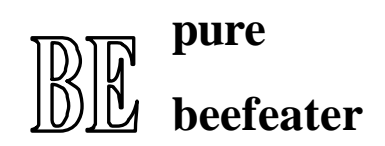

(Figura 110)

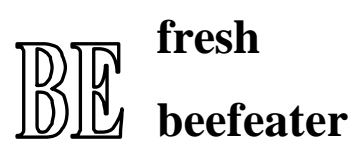

(Figura 111)

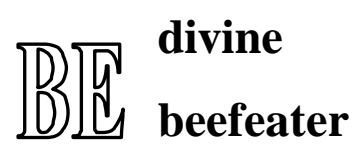

(Figura 112)

Sin embargo, cuando el texto y la etiqueta figuran espacialmente separados, el publicista opta por repetir el término be:

BE yourself

Be beefeater

(Figura 116) 
BE free

Be beefeater

(Figura 117)

\section{BE authentic \\ Be beefeater}

(Figura 118)

Mediante el procedimiento de la repetición, se consigue la asociación entre la invitación al destinatario a expresar alguna de sus cualidades personales positivas y el nombre comercial del producto anunciado. Por su parte, el nombre del producto hace referencia a uno de los cuerpos de guardia más famosos de Inglaterra. Como nos explican los folletos promocionales de la compañía, James Burrough, su fundador "recalled a humorous quote by the Grand Duke of Tuscany in 1669 regarding the hefty size of the Yeoman Warders who guarded William the Conqueror in the $11^{\text {th }}$ Century: "A large ration of beef is given to them daily at court ... and they might be called beef-eaters". 


\subsubsection{2.- Anuncios de Tabaco}

En nuestro corpus aparecen 32 anuncios de tabaco rubio y dos anuncios de tabaco negro. Todos ellos recurren a la técnica de la imagen de marca. Al igual que ocurre con ciertos tipos de bebidas alcohólicas, la publicidad de tabaco sufre diversas restricciones legales que condicionan su aparición en distintos medios de comunicación, hecho que contribuye a resaltar la importancia de los medios impresos en su promoción.

La lengua inglesa tiene una presencia especialmente importante en la publicidad de tabaco debido, entre otros factores, a que "la imagen americana va monopolizando progresivamente el iconismo publicitario del tabaco, al menos en España” (León 1996:207). Al tratarse de un producto que opta por la explotación de la técnica de la imagen de marca su estrategia promocional se centra en transmitir una determinada idea mediante la presentación de situaciones que representen estereotipos de "americanidad" a la que contribuye decisivamente el recurso al uso de la lengua inglesa ${ }^{177}$. Veamos algunos ejemplos.

Leo Burnett, publicista que se definía a sí mismo como líder de la escuela de Chicago y enormemente interesado por la publicidad en prensa, ha conseguido su obra maestra con la campaña de Malboro. Esta campaña llegó a crear una imagen para el producto que "lo convirtió en la marca de cigarrillos más vendida del mundo" (Ogilvy 1986: 15). La imagen del vaquero fumando cigarrillos Malboro en un paradisíaco paisaje americano se ha extendido sin demasiados cambios ${ }^{178}$ a lo largo y ancho de todo el planeta durante cuarenta años y parece que todavía tiene fuerza para seguir. En nuestro corpus aparecen varios anuncios de Malboro con su ilustración característica y cuatro textos diferentes siempre escritos en lengua inglesa:

Malboro Country

Merry Christmas from Malboro Country
(Figura 119)

(Figura 120)

\footnotetext{
${ }^{177}$ Como suele ocurrir en el discurso publicitario, las imágenes que explotan los anuncios de tabaco están más vinculadas a los estereotipos característicos del cine americano que a la verdadera realidad de la sociedad norteamericana.

${ }^{178}$ Hoy en día, por restricciones legales, el protagonista del anuncio no puede aparecer fumando. El discurso publicitario opta entonces por presentar el producto en un contexto determinado esperando que el destinatario se encargue de proveer la conexión entre el producto y la situación representada.
} 
NEW MEDIUM. A new way to flavor

\section{Malboro Lights}

Las campañas de Winston también recurren a la estrategia de asociar mediante la ilustración el producto publicitado con una situación típicamente americana: un saxofonista negro tocando blues, un pianista de jazz, etc. Pero en muchas de sus campañas se alude al origen del producto utilizando un eslogan en castellano - El genuino sabor americano - que contrasta con el eslogan menos explícito y redactado en lengua inglesa de la campaña de Malboro: Come to Malboro Country.

Los anuncios de Chesterfield también utilizan imágenes que responden al estereotipo de "lo americano". En el primer ejemplo vemos a un joven descansando en el capó de un coche situado en un desguace. El único texto que aparece en el anuncio es el siguiente:

\section{The Chesterfield experience}

(Figura 122)

En otro anuncio de la misma campaña la ilustración, en blanco y negro, presenta a una chica rubia vestida con tejanos, botas altas de cuero, camisa sin mangas, pañuelo en el cuello y sombrero bebiendo en un vaso de plástico y sentada de manera muy informal en el respaldo del asiento de un descapotable. La joven está acompañada por un chico rubio que charla animadamente con ella y que viste tejanos, camisa de cuadros abierta y cazadora de cuero negra. El coche está aparcado frente a una hamburguesería de carretera en la que podemos ver el listado de precios: Cheese Burger, Bacon-Cheese Burger, Jumbo Burger, etc. Encima de la barra podemos leer claramente un cartel que informa, en inglés, de que el establecimiento está abierto. El eslogan, único texto que destaca en el anuncio, es el siguiente:

\section{The Chesterfield way of life}

(Figura 123)

Al igual que ocurría en los anuncios de Benetton (figuras 71 y 72) el redactor publicitario recurre en esta ocasión a utilizar en el eslogan la estructura sintáctica de una frase hecha que expresa una idea determinada y que ya es familiar para buena parte de los 
destinatarios. El discurso publicitario adapta estas frases para introducir en ellas el nombre del producto y asociarlo con la idea que la auténtica frase expresa: del conocido concepto The American way of life pasamos a The Chesterfield way of life.

Por su parte, la marca de cigarrillos West muestra la ilustración de un joven luciendo sus tatuajes. En destacados caracteres tipográficos aparece un breve texto en inglés seguido por un eslogan:

\section{Texto: THE TASTE OF NOW}

\section{Eslogan: West - Test it}

(Figura 124)

Lucky Strike ${ }^{179}$ también recurre a la imagen de "lo americano" aunque con una estrategia ligeramente distinta. La campaña de este producto construye diversas situaciones unidas por el hilo conductor de la buena suerte, ya presente en el nombre comercial del producto, enmarcadas bajo los siguientes enunciados:

\section{GET LUCKY}

\section{AN AMERICAN ORIGINAL}

(Figuras 125-129)

Así, se nos presenta una ilustración del patio de la conocida prisión de Alcatraz en la que vemos cómo cuatro asombrados vigilantes observan un agujero en la verja de la prisión. El único rastro del prisionero escapado es una cajetilla de cigarrillos Lucky Strike que bien ha quedado enganchada en la verja o bien ha sido dejada por el fugitivo como señal. En un anuncio diferente (figura 126) podemos observar que un soldado se libra del tradicional corte de pelo militar gracias a su cajetilla de Lucky Strike.

Otro anuncio de la misma campaña (figura 128) nos muestra a un inspector de policía tomando notas para su informe acerca del robo de un diamante guardado en un museo. Los vigilantes del museo contemplan cómo el ladrón ha dejado dentro de la vitrina que custodiaba el diamante una cajetilla de Lucky Strike. Aquí las letras del titular imitan a recortes de periódicos haciendo referencia al formato que suelen utilizar los delincuentes para escribir cartas intimidatorias.

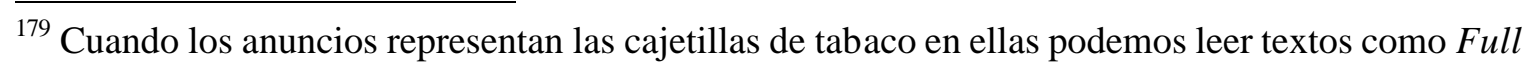
flavor, American blend, King size, Filter cigarretes, etc. 
Después de la publicación del anterior anuncio, la agencia publicitaria opta por seguir con el hilo temático conductor de esta campaña introduciendo un nuevo anuncio. Bajo el mismo titular y la misma rúbrica se nos presenta a un inspector de policía típico de las películas americanas ambientadas en los años treinta leyendo la prensa en su despacho. El titular del periódico Daily Press dice lo siguiente:

\section{LUCKY STRIKES AGAIN ! Fourth Case Unresolved. This time it's a diamond.}

(Figura 129)

El periódico también reproduce la ilustración del anuncio en el que se presentaba el robo del diamante. En el tablero del inspector de policía podemos ver cuatro fotografías de los objetos robados con sus correspondientes bolsitas de las pruebas encontradas. En todas ellas hay una nota en la que se puede leer la palabra EVIDENCE y dentro de éstas hay una cajetilla de Lucky Strike.

El hilo temático de esta campaña se rompe cuando la agencia crea un anuncio relativo a un acontecimiento especial: Lucky Strike patrocina una escudería de fórmula uno. Sin embargo, la imagen americana sigue estando presente ya que el equipo que se patrocina está formado por pilotos británicos y americanos. Junto a la ilustración de un coche de carreras con los colores rojo, blanco y negro característicos de la cajetilla de Lucky Strike se inserta el siguiente texto en lengua inglesa:

\section{THE FINISH LINE IS A STATE OF MIND.}

LUCKY STRIKE RACING

PATROCINADOR OFICIAL

\section{BRITISH AMERICAN RACING FORMULA 1 TEAM}

(Figura 130)

A la hora de anunciar sus cigarrillos light, Lucky Strike recurre a textos completamente escritos en lengua inglesa a excepción de la advertencia legal, obligatoriamente presente en todos los anuncios de tabaco publicados en prensa, donde se especifica la cantidad de nicotina y alquitrán de los cigarrillos y se avisa de los efectos dañinos del tabaco sobre la salud. Los diferentes textos de esta campaña se caracterizan por la repetición del término inglés full con el objetivo de enlazar el carácter light del producto con un segundo término muy transparente para los hablantes de español Emotion, 
Sensation, Temptation - y que, en principio, nada tiene que ver con la naturaleza del producto. El eslogan recuerda su origen americano:

Lucky Strike

Full Emotion

Full lights

AN AMERICAN ORIGINAL

(Figura 131)

Lucky Strike

Full Sensation

Full lights

AN AMERICAN ORIGINAL

(Figura 132)

Lucky Strike

Full Temptation

Full lights

AN AMERICAN ORIGINAL

(Figura 133)

Hasta este momento hemos analizado campañas de cigarrillos comercializados por las multinacionales tabaqueras estadounidenses. Pasamos ahora a referirnos a una marca de tabaco producido por una empresa española: nos referimos a los cigarrillos Fortuna ${ }^{180}$. Consideramos que esta campaña merece una especial atención tanto por su uso de la lengua inglesa como por tratarse de la marca de tabaco más vendida en el territorio español copando un $27^{\prime} 8$ por ciento del mercado ${ }^{181}$.

Sus anuncios presentan normalmente una ilustración de distintos jóvenes junto a una cajetilla del tabaco publicitado. El texto principal del anuncio se redacta en lengua inglesa mientras que el eslogan recurre al español:

$\begin{array}{ll}\text { Texto principal: } & \text { For ever } \\ \text { Eslogan: } & \text { A tu aire }\end{array}$

(Figura 134)

${ }^{180}$ La marca Fortuna pertenece a Tabacalera de España que recientemente se ha fusionado con la compañía francesa Seita para crear la empresa Altadis.

${ }^{181}$ Este dato figura en el suplemento Economía y Finanzas publicado por el diario La Voz de Galicia el dieciocho de agosto de 2000. 
Texto principal: For you

Eslogan: $\quad$ A tu aire

(Figura 135)

Texto principal: For friends

Eslogan: A tu aire

(Figura 136)

El breve texto en inglés se divide en dos partes claramente diferenciadas en todos los anuncios de esta campaña (de la figura 134 a la 138): la primera, únicamente compuesta por la primera sílaba del nombre comercial de estos cigarrillos, aprovecha el grafismo y la maquetación característica de su imagen de marca para recordarnos implícitamente el nombre del producto que se promociona. Esta primera sílaba coincide a su vez con la preposición inglesa for, hecho que se aprovecha para introducir la segunda parte del texto, coherentemente escrito en lengua inglesa: ever / friends / you / light / $n^{\circ} 1$. Así, el texto principal del anuncio recuerda implícitamente el nombre del producto e invita al destinatario a su disfrute mediante un enunciado en inglés que activa diferentes cualidades de carácter positivo.

La cajetilla de cigarrillos aparece en la ilustración de algunos anuncios de esta campaña a modo de rúbrica para corroborar la relación existente entre el texto del anuncio y el producto anunciado (véanse las figuras 134, 136 y 138). En otras ocasiones el anuncio llega incluso a prescindir de su presentación (figura 135).

El recurso al uso de la lengua inglesa es especialmente significativo en los anuncios de Fortuna por tratarse de un producto español que se promociona a través de la lengua inglesa. Al comienzo de este apartado ya hemos destacado el monopolio que la imagen americana llevaba a cabo en la publicidad del tabaco, hecho contrastado mediante los análisis de las diferentes campañas que componen nuestro corpus. En el caso de Malboro, Winston, Chesterfield o Lucky Strike la explotación de la imagen de "lo americano" resulta más sencilla por tratarse de productos que, como es sobradamente conocido por los fumadores, proceden de empresas norteamericanas (Phillip Morris Products Inc. y Reynolds principalmente) con un gran prestigio mundial en la producción de tabaco rubio. Sus anuncios pueden aludir explícitamente a su procedencia americana. Sin embargo, Fortuna no puede declarar abiertamente que sus cigarrillos son americanos ya que sufriría sanciones legales por utilizar información que es demostradamente falsa. No obstante, no se puede 
prohibir que haga uso de un estímulo lingüístico como el inglés que posibilite que los destinatarios del anuncio asocien las cualidades de su producto a las cualidades de los cigarrillos rubios americanos. Este hecho constituye un ejemplo claro de comunicación encubierta: el producto anunciado se beneficia de las inferencias que el destinatario construye respecto a las características del producto, sin llegar, en ningún momento a presentarse explícitamente como un producto perteneciente a una empresa americana o procedente de los Estados Unidos. 


\subsubsection{3. - Anuncios de fragancias}

Como ya hemos adelantado en el apartado 1.7.3.2., los anuncios de fragancias no suelen recurrir a la estructuración tripartita característica de los anuncios en prensa debido a la naturaleza poco informativa del producto que publicitan: los setenta y un anuncios de fragancias que aparecen en nuestro corpus optan por utilizar la técnica de la imagen de marca. Su componente lingüístico es muy escaso y, como hemos visto en el apartado dedicado al análisis estadístico, su cometido se reduce a la presentación del producto y de la casa que lo comercializa especificando a su vez si es para hombre o para mujer. En algunas ocasiones también se introduce un eslogan identificativo del producto frecuentemente redactado en lengua inglesa. No obstante, el componente lingüístico de los anuncios de fragancias es muy similar en todos ellos por lo que en este apartado nos centraremos exclusivamente en el análisis de alguno de los ejemplos más destacados.

Aunque París sigue siendo considerada la cuna de la moda mundial y de los artículos directamente relacionados con ella, como las fragancias ${ }^{182}$, hoy en día debemos señalar que sus productos sufren una gran competencia que proviene de los Estados Unidos. Así, en nuestro análisis distinguiremos entre los anuncios de fragancias que se publicitan aludiendo, de maneras muy distintas, a su origen americano (Elisabeth Arden, Carolina Herrera, Tommy Hilfiger, Ralph Lauren, Hugo Boss, etc.) y las campañas que promocionan productos europeos (Chanel, Christian Dior, Armani, Cartier, etc.) ya que las fragancias europeas, principalmente francesas, hacen un uso de la lengua inglesa más restringido que los productos procedentes de los Estados Unidos. Nueva York es la ciudad que los perfumes americanos toman como referencia, desempeñando un papel similar al de París en Francia.

Una de las fragancias más conocidas de Elizabeth Arden toma su nombre de la calle comercial más importante de Nueva York a nivel internacional y cuya principal

\footnotetext{
${ }^{182}$ Existe una clara relación entre las fragancias más publicitadas y los grandes diseñadores de moda: además de su ropa los diseñadores de moda prestan su nombre para comercializar todo tipo de complementos, que son económicamente más accesibles al gran público. Los anuncios de gafas, bolsos, relojes o fragancias que se presentan como pertenecientes a un determinado diseñador son muy frecuentes en las revistas de mayor difusión en España mientras que los anuncios de ropa son más bien escasos.
} 
característica reside en el supuesto alto poder adquisitivo de los clientes que frecuentan sus establecimientos: $5^{\text {th }}$ Avenue ${ }^{183}$. El eslogan del anuncio utiliza la lengua inglesa para destacar el lugar de origen del producto:

Elizabeth Arden

\section{$5^{\text {th }}$ Avenue}

The modern American classic

Elizabeth Arden

(Figura 139)

En otros anuncios de la misma campaña se hace referencia también en lengua inglesa a las cualidades que se desean asociar con la fragancia publicitada:

Elizabeth Arden

\section{$5^{\text {th }}$ Avenue}

The fragance of sophistication, style and luxury

(Figura 140)

Carolina Herrera también enmarca la presentación de sus perfumes en la ciudad de Nueva York: además de ser un elemento recurrente en buena parte de las ilustraciones, todos sus anuncios mencionan el nombre de la diseñadora seguido por el de esta ciudad norteamericana. Los breves textos que aparecen en los anuncios se redactan en lengua inglesa:

212 MEN. A sense of the city A new fragrance from Carolina Herrera

New York

(Figura 141)

212 A new area in fragrance

Carolina Herrera

New York

(Figura 142)

212

Two fragrances from Carolina Herrera.

New York

(Figura 143)

\footnotetext{
${ }^{183}$ Recurrir a lugares conocidos mundialmente por su exclusividad es una práctica muy común en la publicidad de fragancias. Así, en nuestro corpus podemos encontrar un producto llamado Giorgio Beverly Hills que se publicita bajo el eslogan There's no place like Giorgio. No obstante, la elección de estos lugares responde más frecuentemente a determinados estereotipos que a la realidad.
} 
Herrera for men

Carolina Herrera

New York

(Figura 144)

Las dos campañas que acabamos de comentar se construyen en torno a la imagen de la gran metrópolis americana, Nueva York, de la que se destaca su carácter eminentemente urbano y a la vez lujoso, sofisticado y cosmopolita ${ }^{184}$. Normalmente, los anuncios de fragancias procedentes de los Estados Unidos no utilizan en ningún momento la lengua española, a excepción de instrucciones de carácter práctico como "Levante la pestaña para descubrir Tommy, la nueva fragancia americana" o "Abra y descubra $5^{\text {th }}$ Avenue". Sin embargo, los textos que utilizan se caracterizan por su brevedad y por su transparencia para los hablantes de español. En estos anuncios se muestra con gran claridad el uso intencionado de la lengua inglesa como sociolecto elitista de los países occidentales, frecuentemente asociada a valores relativos al poder económico, el lujo, el éxito, etc.

Otros anuncios de fragancias presentan un concepto de americanidad de apariencia más patriótica. Así, tanto las campañas de Ralph Lauren como las de Tommy Hilfiger dirigidas a un público joven utilizan como motivo recurrente la bandera americana, que puede aparecer en un mástil (figura 145), como fondo sobre el que posan los protagonistas del anuncio (figura 146), en el cinturón y en la camiseta de la modelo (figura 147) o incluso siendo portada por la joven que aparece en la ilustración (figura 148).

La presencia de la bandera americana no termina aquí ya que, además de utilizar predominantemente en todos los anuncios los colores blanco, rojo y azul, tanto el logotipo de Ralph Lauren (figura 147) como el de Tommy Hilfiger (figura 148) juegan con distintos elementos de la enseña norteamericana. Los textos de los anuncios se redactan exclusivamente en lengua inglesa:

Tommy. The real american fragrance

Tommy. The new american fragrance
(Figura 145)

(Figura 146)

\footnotetext{
${ }^{184}$ Tanto la ilustración como el contenido lingüístico del anuncio, además del uso de la lengua inglesa, contribuyen a construir esa imagen. La procendencia hispana del nombre de la diseñadora se ve enmarcado en todo momento por las referencias a la ciudad de Nueva York.
} 


\section{The women's fitness fragrance by Ralph Lauren (Figura 147) \\ Tommy Girl. A declaration of independence (Figura 148)}

En ambas campañas publicitarias parece existir un deseo de competir por presentar el producto más netamente americano. En el ejemplo reproducido en la figura 148 se llega a hacer una alusión al documento que propició la existencia de los Estados Unidos de América: su declaración de independencia.

Las campañas de la Calvin Klein Cosmetic Corporation no recurren a esta tradicional imagen americana, aunque muestran un espíritu muy urbano, mestizo, transgresor y provocador que puede interpretarse como una alusión a la otra cara de la sociedad norteamericana. La lengua inglesa se utiliza para dar nombre a toda su gama de productos - Eternity, Obsession, Contradiction, Escape, etc. - que, como podemos observar, también resultan transparentes para los hablantes de español.

En diferentes manuales de publicidad nos hemos encontrado con la idea de que el público que recibe los anuncios recuerda con mayor dificultad una marca de carácter abstracto, similar a las que encontramos en los anuncios de Calvin Klein, que un nombre que se refiera a un elemento concreto. Sin embargo, Bassat (1993: 40) es contrario a esta idea y afirma que la publicidad genérica tradicional debe ser racional pero, en contraste, la publicidad de imagen de marca debe apelar directamente a las emociones del destinatario. Así se explicaría la estrategia de marketing seguida por Calvin Klein a la hora de dar nombre a sus productos.

Además de los perfumes dirigidos a uno de los dos sexos, esta empresa ha lanzado al mercado diferentes fragancias que pueden ser indistintamente utilizadas por hombres o mujeres: CkOne y CKBe. Ello le ha permitido jugar con uno de los escasos elementos informativos de los anuncios de fragancias, aprovechando el texto escrito en inglés como eslogan del anuncio:

\section{ETERNITY}

Calvin Klein

Fragrances for men and women

(Figura 149) 


\section{Contradiction}

A new fragrance for women

Clavin Klein

(Figura 150)

\section{CKOne}

Clavin Klein

A fragrance for a man or a woman

(Figura 151)

El lanzamiento de CKOne en los Estados Unidos provocó una airada reacción de buena parte de la sociedad americana conservadora al interpretar que el anuncio estaba propugnando unos modelos de comportamiento sexual que contribuían a la confusión de los roles masculino y femenino (obsérvese, además del eslogan, la imagen "asexuada" de los jóvenes modelos del anuncio reproducido en la figura 151). La fragancia CKBe constituye el culmen de ese proceso de asimilación de ambos géneros, nótese el uso del término people, con el objetivo de presentar una fragancia que sirva para los dos:

\section{Be good. Be bad. Just be}

Ckbe. A fragrance for people. Calvin Klein

(Figura 152)

Al igual que ocurría en los anuncios de Swatch Skin (figuras 36 y 37) Calvin Klein publicita su fragancia Contradiction alternando en las revistas en prensa dos anuncios similares: uno de ellos completamente escrito en lengua inglesa (figura 153) y un segundo anuncio que utiliza el inglés exclusivamente para dar nombre al producto (figura 154). Ello parece indicar que cuando se desea que el destinatario acceda al significado del texto en inglés se buscan maneras de hacerlo posible. La forma más habitual consiste en adaptar el texto original en inglés total o parcialmente a las necesidades comunicativas del destinatario presentando un único anuncio. Cuando se opta por combinar dos anuncios, uno común a los países donde se comercializa el producto y otro traducido, se confía en que haya un significativo número de destinatarios que interpreten adecuadamente el texto en inglés y que, mediante la presentación de un nuevo estímulo lingüístico, el acto comunicativo tenga mayor fuerza y de lugar a un cierto número de inferencias positivas que beneficien al producto: 
She is always and never the same

\section{Contradiction}

A new fragrance for women

Calvin Klein

(Figura 153)

El resto de anuncios de fragancias, la mayor parte de los cuales son de origen francés aunque también abundan los productos procedentes de diferentes países europeos, hacen un uso de la lengua inglesa más restringido y la imagen americana que hemos visto en las anteriores campañas se ve sustituida por referencias a las prestigiosas casas comerciales europeas que presentan el producto: Chanel, Dior, Armani, Gucci, etc. Al igual que en la mayor parte de los productos que hemos analizado en nuestro corpus, el inglés se utiliza para dar nombre a las diferentes fragancias $\mathrm{y}$, al haber un mayor componente textual, los términos en inglés se integran dentro de un texto en español:

PORQUE TODOS LOS HOMBRES TIENEN ALLURE ${ }^{185}$

ALLURE HOMME. LA NUEVA FRAGANCIA MASCULINA DE CHANEL

(Figura 155)

¿CUÁL ES LA MEJOR DEFINICIÓN DE “ALLURE” ?

... UN PERFUME INDEFINIBLE Y TOTALMENTE IRRESISTIBLE

ALLURE. EL NUEVO PERFUME DE CHANEL

(Figura 156)

¿Qué sería de la audacia si no tuviera encanto?

SO PRETTY DE CARTIER. PARIS

(Figura 157)

\section{Get together con las dos nuevas fragancias}

\section{EMPORIO ARMANI}

(Figura 158)

No obstante, también existen ejemplos de productos procedentes de casas europeas consagradas que, al presentar un texto breve, recurren a la lengua inglesa:
Dior
Hypnotic Poison
Christian Dior
Paris

\footnotetext{
${ }^{185}$ Tanto el término allure como la palabra poison, que aparece en la figura 159 son ambivalentes en inglés y en francés.
} 


\section{Gucci rush}

The new fragrance for women from gucci.

(Figura 160)

\section{GUCCI}

ENVY

For men and women

(Figura 161)

Nino Cerruti opta por una estrategia distinta al presentar los eslóganes de sus productos en inglés e indicar mediante un asterisco que a pie de página se facilita su traducción al español:

\section{I'm flying*}

* Vuela

LA NUEVA FRAGANCIA PARA HOMBRE DE NINO CERRUTI. CERRUTI IMAGE

(Figura 162)

\section{Design your dream*}

* Construye tus sueños

LA NUEVA FRAGANCIA PARA HOMBRE DE NINO CERRUTI. CERRUTI IMAGE

(Figura 163) 
3.2.4.4. - Aspectos más relevantes de la presencia de la lengua inglesa en productos publicitados utilizando la técnica de imagen de marca

Los anuncios que hemos reproducido en los apartados dedicados a productos que siguen la técnica de la imagen de marca - bebidas, tabaco y fragancias - se caracterizan por su estilo evocativo. El texto del anuncio, frecuentemente redactado en lengua inglesa, se ve relegado a un segundo plano debido al predominante papel de la ilustración que se suele utilizar con el propósito de activar ciertas emociones en el receptor. Ello se debe, al menos en parte, a que la naturaleza de los productos publicitados no permite establecer una distinción objetiva que posibilite diferenciar las distintas marcas que componen el mercado: no resulta sencillo elaborar un anuncio, dirigido a un público no especializado, aludiendo a las cualidades que diferencien una determinada marca de fragancias o whisky de otras similares ya que es muy difícil explicar las características de olores o sabores similares. Así, la estrategia que se utiliza consiste en establecer una relación entre una imagen y un producto que, en principio, casi nada tienen en común si exceptuamos el hecho de que aparezcan en una misma página. El destinatario del anuncio se encarga de proveer la conexión entre ilustración y producto haciendo que éste quede unido a los valores representados en la imagen (véase Williamson 1978: 30).

La mayor parte de los anuncios de bebidas alcohólicas destacan la información relativa a la procedencia del producto: los anuncios de whisky aluden a su origen escocés $^{186}$ - Passport, Cutty Sark, J\&B, White Label, Chivas, Cardhu y 100 Pipers - y los tres anuncios de diferentes marcas de ginebra que aparecen en nuestro corpus Tanqueray, Bombay y Beefeater - señalan su origen inglés: londinense más concretamente. Incluso aparecen dos ejemplos de anuncios de whisky irlandés que se publicitan bajo un titular que presenta una dilogía: Jameson. The spirit of Ireland. Por su parte, las campañas de Vodka Absolut hacen hincapié en su origen sueco.

\footnotetext{
${ }^{186}$ En ciertas ocasiones existen discrepancias acerca del lugar de origen de los productos: tanto Irlanda del Norte como Escocia se atribuyen la invención del whisky. En esta ocasión, más que a su verdadero origen histórico nosotros nos referimos al lugar que tradicionalmente se asocia con el producto.
} 
El prestigio de los licores que provienen del exterior hace que muchos de ellos pongan de manifiesto que se trata de un producto importado: lo pueden hacer mediante una especie de sello o cuño, a través del texto del anuncio o por medio de la ilustración. En todos estos casos la información relativa al origen del producto se presenta en lengua inglesa.

Tanto en los anuncios de tabaco como en los anuncios de bebidas alcohólicas la redacción del texto en inglés parece responder, entre otros factores que mencionaremos a continuación, a un deseo de reforzar la idea de la procedencia foránea del producto. Bassat (1999: 128) destaca que España ha sido, desde siempre, un país que ha confiado más en las marcas extranjeras que en las nacionales y alude a un estudio realizado en 1990 por Landor Associates que, entre otros, arrojaba los siguientes datos: de las diez primeras marcas preferidas por los consumidores españoles sólo cuatro son nacionales. Este resultado convierte a España en el país europeo que más confianza muestra en las marcas extranjeras. Este hecho tiene su reflejo tanto en la publicidad de productos de procedencia foránea como en los anuncios de productos españoles. En sectores como el de la moda muchas marcas españolas llegan a disimular su origen bajo un nombre italiano o anglosajón: Massimo Dutti, Emidio Tucci, Victorio y Luccino, Milano, Springfield, Pull and Bear, Zero, Caroche, etc.

No obstante, sin ignorar los factores relativos al origen del producto, debemos tener muy presente que el recurso a la lengua inglesa favorece el acto comunicativo publicitario dotándolo de un mayor poder de atracción para el grupo de destinatarios a los que va dirigido. Las características de los textos redactados en inglés, compuestos por términos conocidos o transparentes y contextualizados por la ilustración, contribuyen a captar la atención del sector más joven de consumidores de bebidas alcohólicas. Mediante el uso de la lengua inglesa, el anuncio se dirige al mencionado sector de la población intentando buscar su complicidad y dotando así de mayor fuerza al acto comunicativo publicitario: la correcta interpretación de los términos en lengua inglesa produce una satisfacción en el destinatario que le lleva a sentir una cierta afinidad con el anuncio y, por extensión, con el producto anunciado. Este proceso dará lugar a efectos contextuales de carácter positivo para el producto. La mayor ventaja que posee el uso del inglés en la publicidad de esta clase de productos responde a su capacidad para apelar a todos los sectores que componen la juventud española: desde los más integrados en los valores 
consumistas de todo estado capitalista hasta los más inconformistas con el modelo económico de los países occidentales.

Además del recurso de la lengua inglesa, tanto en la mayor parte de las campañas de tabaco como en las campañas de bebidas alcohólicas nos encontramos distintos elementos que muestran un deseo de dirigirse a los consumidores más jóvenes. Los modelos que aparecen en ciertas campañas publicitarias de tabaco (véase Fortuna) y de bebidas alcohólicas (véase Beefeater) destacan por su juventud, hecho que contribuye a facilitar la identificación del target del anuncio. Tampoco debemos olvidar que la preeminencia de la imagen sobre el texto, además de facilitar la adaptación del anuncio a diferentes países, es una estrategia que posibilita una mejor comunicación con sus destinatarios ya que, como hemos visto, la expresión a través de las imágenes posee un valor socio-cultural muy destacado en el sector más joven de la población.

En nuestro análisis hemos comprobado que tanto en los anuncios de bebidas como en los anuncios de tabaco se utiliza frecuentemente la lengua inglesa. Muchos anuncios únicamente recurren al español para enviar mensajes como los siguientes: "Bebe con moderación. Es tu responsabilidad" o "Las autoridades sanitarias advierten que el tabaco perjudica seriamente la salud. Nic.: 0'9 mg. Alq.: $12 \mathrm{mg}$.”, "Las autoridades sanitarias advierten que fumar provoca cancer.", etc.

En el caso del primer texto, que aparece en las bebidas alcohólicas de alta graduación por propia iniciativa del sector, se intenta que el mensaje pase desapercibido camuflándolo en el anuncio. En el caso del tabaco se opta por una estrategia distinta consistente en establecer un fuerte contraste entre el anuncio propiamente dicho y el mensaje relativo a las consecuencias de su consumo. El texto al que estamos aludiendo, que aparece por imperativo legal, se aleja completamente del tono del anuncio de tabaco en sí. Entre los elementos que favorecen este distanciamiento podemos mencionar el hecho de que aparezca sobre fondo blanco y con una tipografía de carácter neutro, su naturaleza informativa, la ausencia de ilustraciones, la alusión al concepto de autoridad (sanitaria) que contrasta con conceptos como libertad, juventud y placer característicos de la publicidad de tabaco y bebidas alcohólicas. Este contraste se ve reforzado por redactarse en español, un idioma que apenas se utiliza en el resto del anuncio.

Todo ello trae como consecuencia que el mensaje de las autoridades sanitarias llegue con menor fuerza que el anuncio en sí a su target: las empresas tabaqueras dirigen 
sus anuncios a un público joven ya que éste resulta más fácilmente influenciable que un público adulto. Además, de esta manera, se aseguran consumidores para el futuro: cuanto más joven se comience a fumar mayores dificultades habrá para dejar el hábito. Países como Canadá, conscientes de este hecho, han tomado medidas al respecto y obligan a que en la publicidad del tabaco aparezcan ilustraciones donde se muestre, en un tono desenfadado, los problemas que acarrea el consumo de tabaco: poco fondo físico, dificultades de erección, halitosis, etc.

La predominante imagen norteamericana que transmite la publicidad del tabaco rubio, el más consumido por la juventud, tiene como resultado manifestaciones que sirven como contrapunto a esta tendencia. Así, Ducados ha construído su última campaña bajo el eslogan de "Sabor Latino" y el whisky Dyc, producido en Segovia, ha optado por sustituír los atractivos modelos característicos de la publicidad multinacional de bebidas alcohólicas por gente de la calle, a la que se refiere como "gente sin complejos". En ambos casos no se recurre en ningún momento a la lengua inglesa.

Para concluir, únicamente poner de manifiesto que mientras los anuncios de tabaco y bebidas alcohólicas se dirigen a todo un sector de la población española caracterizado por su edad y no establecen distinciones basadas en criterios de disponibilidad económica, los anuncios de fragancias que aparecen en nuestro corpus redactados en lengua inglesa parecen estar más interesados en el poder aquisitivo de sus consumidores: tanto los anuncios de fragancias juveniles como los de perfumes dirigidos a la población más adulta tienden a mostrar elementos estereotípocos comúnmente asociados a un poder adquisitivo alto. 


\section{CONCLUSIONES}

A la hora de abordar el trabajo de investigación que hemos presentado nos habíamos propuesto conseguir dos objetivos principales. El primero de ellos consistía en poner de manifiesto la abrumadora presencia de la lengua inglesa en la publicidad española tanto en lo relativo al uso de anglicismos, más o menos integrados en el sistema lingüístico español, como en la utilización de textos íntegramente redactados en inglés. Después de haber establecido la magnitud del fenómeno en las ofertas de empleo (véase el apartado 1.7.2.) y en la publicidad comercial (apartado 1.7.3.), nos hemos marcado un segundo objetivo: encontrar las bases teóricas que nos ayuden a comprender las razones que justifican el recurso a una estrategia comunicativa que radica en el uso por parte del emisor de un estímulo lingüístico en un idioma que no es el esperado por el destinatario.

La multiplicidad de factores que concurren en el discurso publicitario, ya comentados en la introducción, puede servir como justificación a la carencia de estudios sobre el asunto en cuestión basados en la aplicación de las teorías lingüísticas que parten de la naturaleza interactiva de todo acto comunicativo. La teoría de la relevancia de Sperber y Wilson (apartado 2.6.) nos ha parecido el punto de partida más adecuado para llevarlo a cabo debido, entre otros factores, a la importancia que presta a la función del destinatario dentro del acto comunicativo publicitario. Los modelos del código, paradigma dominante en el estudio de la comunicación publicitaria en general (véase el apartado 2.2.) y en el análisis lingüístico del influjo angloamericano en particular (apartado 3.1.1.), asignan al destinatario un papel esencialmente pasivo. Sin embargo, cada vez resulta más notorio que el éxito o fracaso de un anuncio depende en gran medida 
del esfuerzo que éste está dispuesto a hacer para interpretar el mensaje y llegar a las implicaturas perseguidas por el anuncio. En el discurso publicitario las complejas estrategias comunicativas puestas en marcha por el emisor no servirán para nada si el destinatario no decide hacer un esfuerzo para acceder a las implicaturas que caracterizan la comunicación publicitaria. Los particulares condicionantes del fenómeno publicitario contemporáneo, definidos por la imperiosa necesidad de captar la atención de un determinado target, contribuyen a poner de manifiesto la naturaleza interactiva de este particular acto comunicativo.

Antes de adentrarnos en el estudio de la máxima expresión del influjo lingüístico angloamericano en la publicidad española consistente en la utilización de textos total o parcialmente escritos en lengua inglesa para promocionar productos dirigidos a un público cuya lengua de uso común es el español, nos ha parecido conveniente revisar diferentes posturas relativas al uso de los anglicismos en la lengua española con el objetivo de conocer los antecedentes del fenómeno que aquí nos compete y así poder valorarlo en su justa medida. A este propósito hemos dedicado buena parte del primer apartado de nuestro trabajo y de este análisis hemos sacado varias conclusiones, que pasamos a comentar a continuación.

En primer lugar, resulta determinante hacer hincapié en la unión entre las vertientes lingüística y social del tema. Lorenzo (1995) destaca que el concepto de anglicismo podría incluso englobar hechos que aunque no estén marcados por un distintivo lingüístico especial reflejen comportamientos que no hubieran existido sin la influencia de la sociedad anglosajona situando de esta manera el fenómeno en una dimensión difícil de acotar (véase el apartado 1.5.). En el caso que nos ocupa parece imposible imaginar cómo sería la publicidad española sin la influencia angloamericana ya que todos y cada uno de sus componentes reflejan, en mayor o menor medida, ese influjo: desde los productos que se publicitan hasta los medios y estrategias que se utilizan en su promoción. La propia función de la publicidad responde, a su vez, a las demandas del engranaje económico mundial, liderado en estos momentos por una nación anglófona: los Estados Unidos de América. Todo ello hace que resulte imposible determinar el grado de autonomía de un país dentro de un mercado supranacional debido a que se ha producido una globalización en los mercados de compra, en los mercados de trabajo y en los intereses financieros y políticos, factores que han venido acompañados del surgimiento de 
una cultura popular de carácter internacional extendida por los medios de comunicación de masas. Aunque nuestro trabajo de investigación se limita al estudio de ciertos aspectos de carácter lingüístico, no podemos dejar de reconocer que el uso de términos o expresiones en lengua inglesa en la publicidad española es una consecuencia directa de un fenómeno mucho más profundo de carácter social, económico y cultural característico del período histórico que nos ha tocado vivir, como ya hemos dejado claro en el apartado 1.6.

Adoptando una perspectiva más restrictiva que la expresada por Lorenzo (1995), Pratt (1980) también vinculaba la creciente aparición de los anglicismos léxicos a ciertos cambios que acontecían en la sociedad española, afirmando que las nuevas realidades suelen venir acompañadas de su propia etiqueta lingüística. Si este hecho es cierto en todos los ámbitos que se ven afectados por el influjo angloamericano - deportes, economía, cine, política, televisión, etc.- en el caso de la publicidad resulta incluso más patente debido a una multiplicidad de factores de entre los que hemos destacado tres: aspiración hacia un marketing y una publicidad global, preferencia de los hablantes hispanos por lo anglosajón y afán de originalidad en el texto publicitario.

Como hemos observado en el análisis de nuestro corpus una de las razones que favorece la aparicición de anglicismos o términos en lengua inglesa en el discurso publicitario responde a la necesidad de dar nombre al producto o modelo que se presenta. Existe un deseo de presentar todo producto como una nueva realidad, que resulta de una naturaleza más ficticia que verdadera en la mayor parte de los casos. El recurso al uso de la lengua inglesa contribuye a comunicar, de manera encubierta, ese espíritu novedoso y original debido a las inferencias que la lengua inglesa suele producir en el contexto cognitivo de buena parte de la ciudadanía. Mediante esta estrategia se pretende involucrar en este acto comunicativo a consumidores de perfiles muy diversos: jóvenes con cierta competencia en lengua inglesa, ciudadanos cosmopolitas de alto poder adquisitivo familiarizados con la lengua inglesa, consumidores que, aunque no entiendan la lengua inglesa, se sientan atraidos por lo selecto, lo exótico, lo diferente, etc. El análisis de nuestro corpus nos ha mostrado que la asociación entre el inglés y los productos caracterizados por su cuidado diseño, su tecnología puntera, su carácter alternativo o juvenil resulta especialmente destacable.

Además, debemos tener en cuenta los factores relativos a la fuerza expresiva obtenida mediante el uso de un término en inglés dentro de un anuncio en español y a las 
propias características de este idioma, considerado el más apropiado para las funciones perseguidas por el discurso publicitario debido al monosilabismo de sus voces, su profusión léxica, sus significados concentrados, su facilidad para formar compuestos léxicos y estructurales, etc. Tampoco podemos olvidar que en la designación del producto entran en juego factores de carácter práctico como los problemas de copyright a la hora de introducir el producto en diferentes mercados con distintos nombres, el deseo de unificar campañas para construir una imagen de marca uniforme en los países donde se comercializa un determinado bien de consumo, etc. Todos estos factores contribuyen a que el producto promocionado se presente muy frecuentemente a través de un término directamente vinculado a la lengua inglesa.

No obstante, tampoco debemos pensar que el uso de términos en lengua inglesa en diferentes países no anglófonos se produce de una manera automática y sin una intencionalidad y reflexión previas ya que las agencias publicitarias se preocupan de analizar cuidadosamente la predisposición de los diferentes mercados hacia ese idioma. La elección del nombre bajo el que se comercializará el producto publicitado no es una cuestión trivial para las empresas, como lo prueba el hecho de que se dedique una ingente cantidad de tiempo y dinero a conseguir ese objetivo:

The fact that producers are willing to pay significant ammounts of money to brand-name consultants is an indication of the extent to which success or failure is thought to rest with this aspect of advertising language. A short list of three names to cover the United Kingdom costs 15,000 pounds and a corporate name for use woldwide 90,000 pounds. (Goddard 1998: 81)

Como hemos visto a lo largo de este trabajo, no todos los anglicismos presentes en el discurso publicitario responden a los mismos objetivos: en algunas ocasiones pretenden calar en determinadas situaciones, principalmente en el contexto de compra de un producto, donde se intenta que el consumidor utilice el término en lengua inglesa para solicitar un bien de consumo. En otras ocasiones, los anglicismos se utilizan para designar las nuevas características propias de un determinado producto. Cuando éstos vienen a rellenar un "ecological hole" (pág. 52) en el lenguaje que los recibe su carácter tiende a ser más perdurable pudiendo llegar a formar parte del lenguaje cotidiano. (véase el apartado 1.5.) 
No obstante, en la mayoría de los casos, el principal objetivo de los términos en lengua inglesa reside en presentar un nuevo estímulo lingüístico que dote al anuncio de un mayor poder de atracción para el destinatario y no en intentar asentar su uso en el lenguaje, respondiendo entonces a cuestiones de estilo que persiguen aportar una mayor viveza al acto comunicativo publicitario. Así, la fuerza perlocutiva que se imprime al texto resulta determinante pudiendo incluso llegar a anular la función ilocutiva del término o expresión redactada en lengua inglesa ya que, en numerosas ocasiones, lo relevante es su efecto y no su contenido. La constante innovación lingüística constituye uno de los imperativos del discurso publicitario y su principal función reside en contrarrestar el rápido desgaste que sufren los términos y modos de expresión característicos del lenguaje publicitario. El uso de un vocabulario técnico, actual y variado, normalmente de procedencia anglosajona, contribuye a mejorar la opinión que el destinatario tiene del emisor, confiriéndole un mayor prestigio. Sin embargo, esta innovación no puede llevarse excesivamente lejos ya que el lenguaje publicitario se caracteriza por presentar "a delicate compromise between the tendencies of comformity and unorthodoxy" (Leech 1966: 4).

Si este hecho es un factor destacado en el caso de numerosos anglicismos o términos en inglés que designan o se atribuyen a un producto, en lo que se refiere al uso de expresiones o textos íntegramente escritos en inglés constituye la única explicación fundada. El caso de los eslóganes, cada vez más frecuentemente redactados en lengua inglesa en la publicidad española actual, resulta especialmente notorio: su objetivo no reside en llegar a calar en el lenguaje sino que únicamente responden a su función perlocutiva y al deseo de actuar como denominador común de una determinada marca comercial. Aunque el hecho de que, bien por su monosilabismo bien por su matiz diferencial, muchos anglicismos han entrado en el idioma español a través de la publicidad resulta incontestable, no es menos cierto que la mayor parte de los anglicismos y expresiones en inglés presentes en los anuncios no pretenden calar en el lenguaje y bien nunca llegan a utilizarse o bien caducan con facilidad.

La teoría de la relevancia puede explicar de manera clara la atracción que hoy en día despierta el uso de la lengua inglesa en los destinatarios de los textos publicitarios. En primer lugar, debemos destacar que este modelo comunicativo no ha sido exclusivamente concebido para el análisis de los aspectos verbales de la comunicación sino que siempre 
se ha considerado válido para explicar cualquier tipo de comportamiento comunicativo. En segundo lugar recordemos que la teoría de la relevancia parte de la siguiente idea: las pautas que rigen la comunicación inferencial se basan en las características que condicionan la cognición humana. No creemos necesario abundar en la idea de que los publicistas también construyen sus mensajes con la intención de sacar el máximo partido de las estrategias cognitivas que los destinatarios utilizan de manera natural al enfrentarse a un anuncio ya que es por todos conocido que un redactor publicitario dedica una ingente cantidad de tiempo y esfuerzo a buscar el enunciado que produzca el efecto deseado en el entorno cognitivo del destinatario. Este planteamiento coincide con la premisa de la teoría de la relevancia que afirma que el emisor siempre utiliza el estímulo que considera más relevante para la persona cuyo entorno trata de modificar. La vertiente economicista del máximo efecto mediante el mínimo esfuerzo resulta muy adecuada para el estudio de la comunicación publicitaria, hecho que ha sido pasado por alto por los análisis semióticos del fenómeno publicitario que no han considerado, entre otros factores, la diferencia entre el significado de un enunciado en sí y su función en un acto comunicativo determinado (véase el apartado 2.3.).

Como hemos visto a lo largo de nuestro trabajo, la inicial falta de confianza y cooperación que caracteriza a nivel social la relación existente entre el emisor de un anuncio y sus destinatarios hace que este acto comunicativo suela desarrollarse dentro del ámbito de la comunicación inferencial. Las implicaturas presentes en los anuncios hacen que resulte difícil dudar de su veracidad y al mismo tiempo contribuyen a implicar al destinatario en este acto comunicativo: cuanto mayor sea la información implícita recuperada, mayor será el grado de cooperación con el anuncio. La complicidad del destinatario en la recuperación del significado posibilitará un gran enriquecimiento del acto comunicativo publicitario, algo que resultaría muy difícil si el emisor hubiese optado por presentar toda la información de forma explícita. La estrategia del uso de la lengua inglesa resulta muy adecuada para este propósito ya que vincula el procesamiento del anuncio con la persuasión, contribuye a fomentar la implicación del destinatario e incluso posibilita la comunicación encubierta. Todos estos factores han sido analizados en el apartado 2.7.2. de nuestro trabajo.

Los análisis basados en el modelo del código concluyen que el uso de expresiones en lengua inglesa en la publicidad española responde a un deseo de asociar el bien de 
consumo publicitado con su país de origen, confiriéndole así prestigio, autenticidad y un cierto valor añadido mediante las connotaciones que se derivan de la utilización de la lengua inglesa. Sin embargo, el fenómeno que hemos analizado a lo largo de este trabajo es de una complejidad mucho mayor que lo que parece indicar la anterior idea. Mediante el análisis de nuestro corpus hemos podido refutar la idea de la vinculación entre el origen del producto y el uso de la lengua inglesa ya que nos hemos encontrado con multitud de productos que no provienen de países anglófonos pero recurren decididamente al inglés: Benetton, Sisley, Armani (Italia), Camper, Panama Jack, Fortuna (España) Nokia (Finlandia), Ericsson, Absolut y Volvo (Suecia), TagHeuer, Swatch, Movado (Suiza) Alcatel, Dior, Cartier (Francia), Adidas, Siemens, BMW, Opel (Alemania), etc. Por otra parte, también hemos encontrado diferentes categorías de productos, automóviles y servicios bancarios principalmente, que aunque provienen de países anglófonos no manifiestan una presencia destacable de la lengua inglesa. Como hemos comprobado en el análisis de nuestro corpus, la naturaleza del producto publicitado condiciona de manera notable las estrategias utilizadas en su promoción.

Tampoco creemos cierto que el destinatario de un anuncio interprete el texto en lengua inglesa buscando una asociación del producto con una idea establecida de antemano, como parecen interpretar las teorías basadas en el modelo del código. Las implicaturas que se deriven de este uso dependerán tanto del particular contexto cognitivo de cada destinatario como de su percepción del producto. El publicista se preocupará de averiguar cuál es ese contexto cognitivo mediante el estudio del perfil del target del anuncio estimando los efectos contextuales que probablemente se producirán en cada acto comunicativo ya que el uso de la lengua inglesa puede dar lugar a implicaturas de carácter muy distinto. Sin embargo, no podrá cuantificar el esfuerzo de procesamiento que el destinatario deba hacer para acceder a esa información implícita ni tampoco sabrá si considerará estas implicaturas interesantes o aburridas ya que ello dependerá tanto de su particular contexto cognitivo como de la pericia del redactor publicitario a la hora de presentar la información explícita.

Por otra parte, debemos tener en cuenta los condicionantes macroeconómicos característicos de nuestro tiempo e ignorados por las explicaciones basadas en el modelo del código. Ya hemos comentado que las estrategias de marketing de las grandes empresas no se dirigen exclusivamente a un país determinado sino que se llevan a cabo 
considerando las áreas a las que se destinan: espacios económicos formados por distintos países unidos por factores sociales, culturales, geográficos, lingüísticos, etc. El recurso al uso de la lengua inglesa también podría vincularse al deseo de avanzar hacia una publicidad global en un mundo donde los gustos y los hábitos de consumo son cada vez más parecidos. Las grandes empresas multinacionales, siguiendo criterios puramente económicos, aspiran a homogeneizar los gustos de sus potenciales clientes distribuidos en multitud de países distintos borrando, en la medida de lo posible, las posibles diferencias culturales. Estos procesos de homogeinización cultural, alentado por intereses económicos transnacionales, han sido duramente criticados (Tunstall 1977, Phillipson 1992, León 1996) por atentar contra la diversidad cultural de los pueblos y por ayudar a consagrar el dominio del mundo por la superpotencia americana. Como hemos visto en la introducción a este trabajo los planteamientos de organización de las grandes agencias publicitarias también facilitan el influjo lingüístico angloamericano.

Una vez mencionados los anteriores factores de naturaleza extralingüística, debemos tratar los efectos puramente linguísticos de utilizar un estímulo que el destinatario no percibe como propio. En esta ocasión, no nos referiremos al uso de anglicismos, más o menos integrados en el sistema lingüístico español, sino al uso de textos en lengua inglesa que intencionalmente violan el curso lingüístico esperable del anuncio publicitario. Este fenómeno puede incluso llegar a desplazar completamente al español y así en nuestro corpus aparece un nutrido número de anuncios que se redactan exclusivamente en lengua inglesa.

Existe una clara relación entre la presencia de la lengua inglesa y la estructura textual que manifiestan los anuncios. Cuando éstos optan por la superestructura de la solución de problemas, compuesta por cuatro elementos - situación, problema, solución y evaluación - y normalmente presentados en la página a través de la estructuración tripartita tradicional (véase el apartado 3.2.1.3.), el uso de la lengua inglesa está integrada dentro de un texto en español que normalmente aclara el significado de las expresiones en inglés. Sin embargo, cuando los anuncios optan por la estructura topic-restrictionillustration, asociada a la técnica de la imagen de marca (apartado 3.2.1.2.), el carácter del anuncio es menos informativo y su componente textual puede redactarse íntegramente en lengua inglesa llegando, en numerosas ocasiones, a anularse su función ilocutiva debido a la preeminencia de los factores perlocutivos. Cuanto más evocativo sea el elemento 
textual del anuncio, más posibilidades existen de que se redacte en inglés. En ambos casos, la presencia de la lengua inglesa debe considerarse como una característica propia del discurso publicitario actual en España y su abundancia nos indica que el uso de un idioma supuestamente desconocido por buena parte de sus destinatarios no sólo no imposibilita la comunicación, como cabría esperar si seguimos los presupuestos del modelo del código, sino que favorece el acto comunicativo publicitario.

En primer lugar, destacaremos que presentar un estímulo lingüístico mediante un código que no es el esperado por el destinatario constituye una llamada de atención ya que la utilización de la lengua inglesa es un comportamiento comunicativo no habitual en las situaciones comunicativas cotidianas de esos lectores. La lengua inglesa contribuye a que el anuncio, situado en la periferia de nuestra atención, capte la atención de un buen número de destinatarios funcionando entonces como un "attention grabbing device" (Cook 1992: 217). El mayor esfuerzo de procesamiento que el destinatario se ve obligado a hacer para interpretar el texto en lengua inglesa se ve compensado por los efectos contextuales que éste produce en su entorno cognitivo. El uso de expresiones en inglés en la publicidad española es coherente con los principios de la teoría de la relevancia por constituir la manera más sencilla de producir los efectos contextuales perseguidos por el redactor del anuncio. El publicista asume de buen grado el riesgo que supone ese esfuerzo de procesamiento inicial, necesario para que el acto comunicativo se produzca, ya que su mayor preocupación reside en captar la atención de su target, hecho que no se producirá si el anuncio no logra vencer la indiferencia o la desconfianza de su público. El reconocimiento de esta situación debe constituir el punto de partida para el análisis de las estrategias que caracterizan el acto comunicativo publicitario ya que todas ellas se encaminan a vencer este primer rechazo y conseguir la persuasión del destinatario.

Otro de los propósitos que se persigue mediante el uso de la lengua inglesa responde a un deseo de búsqueda de cooperación y complicidad con los destinatarios que posean cierta competencia comunicativa en ese idioma. El redactor publicitario intenta que el destinatario se sienta halagado por haber entendido un texto en lengua inglesa, normalmente contextualizado por la ilustración y la naturaleza del producto, cuyos términos bien no difieren en exceso de sus correspondencias en español o bien son relativamente conocidos. La satisfacción de haber estado a la altura de las circunstancias producirá en el destinatario ciertos efecto s contextuales que beneficiarán su percepción 
del producto, tal y como ocurre en las campañas de Beefeater, Fortuna y J\&B, entre otras (véase el apartado 3.2.4.). La existencia de implicaturas débiles también le permitirá cierta holgura para adaptar el significado del anuncio a su gusto con lo que se garantiza un grado de creatividad en el acto comunicativo. Además, cuanto mayor sea el número de implicaturas contextuales recuperadas por el destinatario y cuanto más tiempo invierta en procesar el texto del anuncio, más sencillo le resultará recordar el producto como hemos visto en el apartado 3.1.2.3.

El recurso de las implicaturas contextuales posibilita, en numerosas ocasiones, el surgimiento de la comunicación encubierta donde, además de involucrar completamente al destinatario en el acto comunicativo, el anuncio se limita a presentar un estímulo basado, en esta ocasión, en el uso de un código lingüístico distinto, que será interpretado por el destinatario de manera personal y dependiendo de sus supuestos acerca de la lengua inglesa. Mediante la comunicación encubierta, el redactor publicitario elude cualquier obligación relativa a las inferencias que el destinatario construya acerca del producto promocionado ya que, al no haber expresado su intención comunicativa, le responsabiliza completamente de la activación de los supuestos e implicaturas que recupere.

Después de haber analizado los diferentes anuncios que componen nuestro corpus podemos afirmar que existe una clara relación entre el uso de mensajes en lengua inglesa y el sector de la población al que van destinados esos mensajes: cuando el producto se dirige a un público joven, con mayores conocimientos de inglés y con unas preocupaciones distintas a las de otros segmentos de la población a la hora de adquirir un determinado producto, se opta muy frecuentemente por presentar el contenido lingüístico del anuncio en lengua inglesa. Además de una cierta competencia en inglés, este fenómeno puede responder al hecho de que tanto los hábitos de consumo como las preferencias de los jóvenes a la hora de adquirir un producto - modernidad, diseño, despreocupación por el precio, exclusividad, etc. - muestren una tendencia bastante uniforme en los países que componen el mundo occidental. El influjo de la lengua inglesa en la publicidad española también obedece al prestigio económico inherente a cualquier elemento que se considere propio de un estado superdesarrollado como, por ejemplo, su idioma. Este hecho se ve acrecentado en España por la inexistencia de una conciencia fuerte de identidad como país y por una cierta preferencia de los consumidores por los productos de origen foráneo (véanse los apartados 1.6.3.2. y 3.2.4.4.). 
La lengua inglesa posee un decisivo poder de atracción para la juventud española, siempre dispuesta a acoger todo elemento que se distinga por su supuesta modernidad y resulta sorprendente comprobar la facilidad con la que este idioma conecta con los distintos grupos sociales que la componen: desde los JASP (Jóvenes aunque sobradamente preparados) a los que aludía un anuncio de automóviles imitando el acrónimo anglosajón WASP, hasta los jóvenes con ciertos valores contraculturales, de carácter más independiente. Como ya hemos comentado, el influjo de la lengua inglesa en España abarca desde ámbitos tan marginales como el de la toxicomanía hasta campos como el deporte, la informática, la música, etc.

La publicidad, en contacto permanente con la realidad social de cada momento, aprovecha este hecho recurriendo al inglés cuando dirige sus productos a la juventud y más si cabe, cuando el bien de consumo es caro, moderno, tecnológicamente avanzado, exclusivo, etc. El target y la naturaleza del producto resultan mucho más decisivos que el país de origen del producto o la nacionalidad de la agencia que se encarga de crear la campaña a la hora de justificar el uso de la lengua inglesa. Veamos un ejemplo. En uno de sus tratados sobre publicidad, Bassat (1999: 102) comenta cómo Ogilvy y Mather Londres había pedido ayuda a su agencia para relanzar un determinado producto, el helado Calippo, a diversos países europeos. Al tratarse de un helado poco convencional dirigido al sector joven del mercado se decide hacer hincapié en las distintas formas en las que se puede comer: congelado, líquido, con cucharilla, etc. El eslogan que se utiliza es el siguiente: Do it your way. Calippo. Esta campaña, cuyo único mensaje textual era el anterior eslogan en inglés fue creada en Barcelona y exportada a cuarenta países diferentes.

Existe un fenómeno que, aunque no es frecuente en la publicidad comercial, ocurre con profusión en la promoción de productos normalmente relacionados con diferentes corrientes musicales, dirigidos al sector más inconformista de la juventud. En la promoción de discos compactos, conciertos, videos o libros relativos a estos temas se utilizan textos en lengua inglesa con un contenido que si no se hubiera presentado en este idioma, podría ser objeto de censura. Permítaseme una pequeña anécdota alusiva al tema en cuestión. En uno de mis primeros días de trabajo como docente en la Escuela 
Universitaria de Educación de Ávila, observé con curiosidad la presencia de un cartel que, en el tablón de anuncios de la Escuela, anunciaba un concierto de un grupo de rock llamado Motherfuckers donde se aludía a alguna de sus canciones con títulos como Fuck you nigger, Rotten Asshole, Kill the cop, etc. Dudo mucho que si este mismo cartel estuviera redactado en español, disfrutara de tan destacado emplazamiento.

En el anterior ejemplo, el uso de la lengua inglesa se utiliza para restringir el acceso al mensaje a las personas que no formen parte del target elegido. En el caso de la publicidad comercial, existe una estrategia similar: cuando se recurre a la lengua inglesa se vende la modernidad, la originalidad, y el diseño del producto, factores importantes para un público joven y se dificulta el acceso a la gente más adulta que normalmente muestra otras preferencias a la hora de adquirir un determinado bien de consumo: precio, calidad, durabilidad, etc.

Buena parte de las campañas de tabaco y bebidas alcohólicas que aparecen en nuestro corpus (véanse los apartados 3.2.4.1 y 3.2.4.2) se distinguen por mostrar una destacada presencia de la lengua inglesa, hecho que suele explicarse aludiendo a diferentes factores: se trata de campañas multinacionales, los anuncios son poco informativos, los productos suelen proceder de países anglófonos, el texto es un mero ornamento, etc. Sin embargo, consideramos que los factores más decisivos para el uso de la lengua inglesa responden tanto a la naturaleza del producto y al target al que se dirigen como a la fuerza perlocutiva que imprimen al acto comunicativo publicitario. 


\section{BIBLIOGRAFÍA}

AAKER, D. y J. MYERS (1984): Management de la publicidad II. Barcelona: Editorial Hispano Europea.

(1975): Advertising. Hemel Hempstead: Prentice Hall.

AGUADO DE CEA, G. (1992): Problemas de traducción de la terminología informática en España. Tesis doctoral inédita. Universidad Complutense de Madrid.

ALARCÓN CASTAÑER, P. (1998-99): "Relaciones sintagmáticas: norma e infracciones en textos creativos en lengua española" en Revista Española de Lingüística Aplicada. Volumen 13, Logroño, 103-110.

ALBA DE DIEGO, V. (1975): El lenguaje de la publicidad. Madrid: Facultad de Filosofía y Letras.

ALONSO, D. (1981): "El español, lengua de millones de centenares de hablantes. Sus problemas a fines del siglo XX" en I Simposio Internacional de Lengua Española. M. Alvar (coord.), Gran Canaria, 419-426.

ALONSO PASCUAL, J. (1996): Anglicismos deportivos. Valladolid: Junta de Castilla y León. Consejería de Educación y Cultura.

ALVAR EZQUERRA, M. (ed.) (1994): Diccionario de voces de uso actual. Madrid: Arco Libros.

ÁlVAREZ GONZÁlEZ, R. y P. CRUZ CANTERO (1994): "Evolución de la especialización profesional en España durante los 10 últimos años según la oferta de empleo publicada en El País/Negocios entre 1983 y 1993" en El País/Negocios, año X, número 479 (13/XII/1994), 22. 
ALZUGARAY, J.J. (1979): Voces extranjeras en el lenguaje técnico. Madrid: Alhambra. (1982): Extranjerismos en el deporte. Barcelona: Editorial Hispano

Europea.

AUSTIN, J. L. (1962): How to do things with words. London: Oxford University Press.

BARTHES, R. (1957): Mythologies. París: Seuil.

(1970): "Retórica de la imagen" en La semiología, Buenos Aires: Editorial Tiempo Contemporáneo, 127-140 (publicado en francés en 1964).

BASSAT, L. (1993): El libro rojo de la publicidad. Barcelona: Ediciones Folio. (1999): El libro rojo de las marcas. Madrid: Espasa Calpe.

BEAUGRANDE, R. de (1980): Text, Discourse and Process. Toward a Multidisciplinary Science of Text. Londres: Longman.

(1991): Linguistic Theory: The Discourse of Fundamental Works.

Londres: Longman.

BEAUGRANDE, R. de y W. DRESSLER (1981): Introduction to Text Linguistics. Londres: Longman.

BENCHERIFF, S. y K. TANAKA (1987): "Covert forms of communication” en Papers of the Autumn Meeting of The Linguistic Association of Great Britain. Bradford, September.

BELL, A. (1991): The Language of New Media. Oxford: Blackwell.

BELL, A. y P. GARRETT (1998): Approaches to Media Discourse. Oxford: Blackwell Publishers Ltd.

BELTRÁN y CRUCES, R. E. (1985): Publicidad en medios impresos México: Trillas Editores.

BERGER, J. (1972): Ways of seeing. London: Penguin books.

BEVAN, M. (1886): A study of the televison commercial as micro-drama. Egham: Royal Holloyay, University of London. Thesis (M.A.).

BLAKEMORE, D. (1987): Semantic Constraints on Relevance. Oxford: Blackwell. 
Presencia de la lengua inglesa en la publicidad española 354

(1988): "The organization of discourse" en Linguistics: The Cambridge

Survey. Volumen IV, Newmeyer (ed.) Cambridge: Cambridge University Press, 229-250.

(1992): Understanding Utterances: An Introduction to Pragmatics.

Oxford: Blackwell.

BLOCK DE BEHAR, L. (1973): El lenguaje de la publicidad. México: Siglo XXI Editores.

BLOOMFIELD, L. (1933): Language. Chicago: University of Chicago Press.

BOGART, L. y B. STUART TOLLEY (1988): “The Search for Information in Newspaper Advertising” en Journal of Advertising Research. Volumen 28, abril 1988, 9-19.

BOLINGER, D. (1980): Language. The Loaded Weapon. The Use and Abuse of Language Today. Nueva York: Longman.

BROWN, J.A.C. (1978): Técnicas de persuasión. Madrid: Alianza Editorial.

BROWN, G. y G. YULE (1983): Discourse Analysis. Cambridge: Cambridge University Press.

BYRNE, B. (1992): Relevance Theory and the language of advertising. Dublin: Trinity College. Centre for Language and Communication studies.

CANO AGUILAR, R. (1995): "La historia del español" en La lengua española, hoy. M. Seco y G. Salvador (Coord.) Madrid: Fundación Juan March.

CARDONA, D. y R. FERNÁNDEZ BERASARTE (1972): Lingüística de la publicidad. Palma de Mallorca: Papeles de Son Armandans.

CARON, J. (1983): Las regulaciones del discurso. Psicolingüística y pragmática del lenguaje. Madrid: Editorial Gredos.

CHESHIRE, J. (ed.) (1991): English Around the World. Sociolinguistic Perspectives. Cambridge: Cambridge University Press.

CONEJERO, M. (1995a): Niveles de significado en el lenguaje publicitario.Valencia: Nau Llibres. 
(1995b): La comunicación especializada: los modelos del lenguaje publicitario. Valencia: Nau Llibres.

(1995c): La sistematización lingüística del lenguaje publicitario.

Valencia: Nau Llibres.

COOK, G. (1992): The discourse of Advertising. London: Routledge.

CORRALES CRESPO, P. (1996): "El tópico de la construcción e interpretación del texto publicitario" en Boletín de Alumnos de Doctorado. Depto. Filología III, Facultad de CC. de la Información, Universidad Complutense de Madrid, número 2, septiembre 1996, 33-42.

CROMBIE, W. (1985): Discourse and Language Learning: a Relational Approach to Syllabus Design. Oxford: Oxford University Press.

CRYSTAL, D. (1997): English as a Global Language. Cambridge: Cambridge University Press.

( 1999): "On trying to be Crystal-clear: a response to Phillipson Response" en The European English Messenger. M. A. Kayman (ed.), Vol VIII/1, primavera 1999, 5966.

DELBECQUE, N. y K.U. LEUVEN (1990): “El lenguaje de la publicidad y su poder de sugestión. Anuncios publicitarios en El Pais Semanal: los tópicos más frecuentes y su formulación” en Linguística Española Actual, volumen XII, Madrid, 1990, 197-214.

DE MIGUEL, A. (1985): La perversión del lenguaje. Madrid. Espasa Calpe.

DÍEZ ARROYO, M. (1995): "Lexical ambiguity in Ads" en Estudios Ingleses de la Universidad Complutense. Madrid: Servicio de Publicaciones Universidad Complutense, número 3, 1995, 187-200.

(1998): La retórica del mensaje publicitario. Un estudio de la publicidad inglesa. Universidad de Oviedo: Servicio de Publicaciones.

DUCROT, O. (1982): Decir y no decir. Barcelona: Anagrama (publicado en francés en 1972).

DURAND, J. (1970): "Rhétorique et image publicitaire" en Communications 15, 70-95. 
DYER, G. (1992): Advertising as Communication. Londres: Methuen (primera edición en 1988).

ECO, U. (1979): The Role of the Reader: Explorations in the semiotics of texts. London: Hutchinson University Press.

(1984): Obra Abierta. Barcelona: Planeta de Agostini.

EFE (1992): El neologismo necesario. Madrid: Fundación EFE.

EGUIZABAL MAZA, R. (1990): El mensaje publicitario. Madrid: Colección tesis doctorales. Universidad Complutense.

ELORZA, I (1995): "El inglés como recurso intencional en las ofertas de empleo en

España” comunicación presentada en el Simposio Internacional "Lingüística y

Sociedad”. Universidad de Salamanca, 25 y 26 de Mayo (no publicada).

ESCANDELL VIDAL, V. (1993): Introducción a la pragmática. Madrid: Anthropos.

ETIEMBLE, R. (1964): Parlez vous Franglais? París: Gallimard.

FELIU GARCÍA, E. (1983): "Publicidad y connotación: el mensaje de inferencia" en Estudios de lingüística. Volumen 1, Universidad de Alicante, 113-125.

(1984): Los lenguajes de la publicidad. Universidad de Alicante:

Servicio de Publicaciones.

FERGUSON (1992): "Foreword to the First Edition" en The Other Tongue. English Across Cultures. B.B. Kachru (ed.), Illinois: University of Illinois Press.

FERNÁNDEZ GARCÍA, A. (1972): Anglicismos en el español. Oviedo: Gráficas Lux FERRAZ MARTÍNEZ, A. (1993): El lenguaje de la publicidad. Madrid: Arco Libros.

FERRER RODRÍGUEZ, E. (1989): “El lenguaje publicitario en la comunicación” en Revista de Occidente, número 92, enero 1989, 23-37. (1994): El lenguaje de la publicidad. México: Fondo de cultura económica.

FISHMAN, J.A. (1968): "Sociolinguistic perspectives in the study of bilingualism" en Linguistics, 39, 21-50. 
(1992): "Sociology of English as an Additional language" en The Other Tongue. English Across Cultures. B.B. Kachru (ed.), Illinois: University of Illinois Press. FODOR, J. (1983): The Modularity of Mind. Cambridge, Massachusetts: MIT Press.

FRIES, P. H. (1992): "Information flow in written advertising", en Georgetown University Round Table on Language and Linguistics 1992: Language, Communication and Social Meaning. James Alatis (ed.), Washington D.C.: Georgetown University Press, 336-52.

GARRIDO MEDINA, J. (1999): "Relevancia frente a retórica: reivindicación del arte de hablar" en Espéculo. Revista de estudios literarios. Universidad Complutense de Madrid, número 13.

GHADESSY, M. (ed.) (1995): Thematic Development in English Texts. London: Pinter Publishers.

GIL SALOM, M. L. (1986): El anglicismo en el campo de la informática. Tesis de licenciatura. Universidad de Valencia.

GIMENO, F. y M. V. GIMENO (1991): "El estado de la cuestión sobre el anglicismo léxico" en Actas del III Congreso Internacional de El Español de América. C. Hernández et al. (eds.), Valladolid, Junta de Castilla y León, tomo 2, 741-749.

GODDARD, A. (1998): The language of Advertising. London: Routledge.

GODDARD, K.A. (1977): "Some linguistic considerations affecting loan-words and lexical borrowing in Romance" en Semasia, 4, 101-114.

(1980): “Loan-words in Spanish. A Reappraisal” en Bulletin of Hispanic Studies, LVII, 1-16.

GÓMEZ CAPUZ, J. (1991): "Para una clasificación tipológica de los anglicismos en español actual” en Lingüística Aplicada y Tecnología. Actas del I Simposio. J. Calvo (ed.), Valencia: Universitat de Valencia, 63-70.

(1993): "Tendencias en el estudio de las diversas etapas de la influencia angloamericana en español moderno (con especial atención al nivel léxico)" en Actas del 
tercer congreso internacional de historia de la lengua. Salamanca: Universidad de Salamanca, 1289-1307.

(1995): "Aportaciones a un estudio contrastivo de la influencia angloamericana actual en español, francés e italiano" en Atti del XXI Congreso Internazionale di Lingüística e Filologia Romanza. Giovanni Ruffino (ed.), Palermo: Universitá di Palermo, Settembre 1995.

(1995): "El efecto del anglicismo en el español hablado y coloquial de España y de Hispanoamérica: análisis contrastivo" en Actas del I Congreso de Historia de la Lengua española en América y España. M. Teresa Echenique et al. (eds.), Universidad de Valencia: Departamento de Filología española, 507-511.

(1997): "Towards a typological classification of linguistic borrowing (illustrated by Anglicisms in Romance Languages)" en Revista Alicantina de Estudios Ingleses, número 10, 81-94.

(1997): "La madurez del anglicismo en español actual: el ejemplo de la lengua juvenil" en Actas del V Encuentro de la Asociación de Jóvenes Lingüístas. R. Lineros et al. (ed.), Universidad de Murcia: Servicio de Publicaciones, 29-39.

(1998): El préstamo lingüístico. Conceptos, problemas y métodos. Anejo número XXIX de la Revista Cuadernos de Filología. Universitat de Valencia: Departamento de Filología Española.

GÖRLACH, M. (1988): "English as a world language - the state of the art" en Folia Lingüística, XXXVII, 1-2, Berlin: Mouton-de Gruyter,171-192.

GRADDOL, D. (1999): "The decline of the native speaker" en English in a Changing World. David Graddol et al (ed.), Guilford: Biddles Ltd.

GRANDI, R. (1995): Texto y contexto en los medios de comunicación. Barcelona: Bosh Casa Editorial.

GRAY, L.H. (1950): Foundations of language, Nueva York (segunda edición).

GREENE, J. (1986): Language Understanding: A Cognitive Approach. Milton Keynes: Open University Press. 
GRICE, H. P. (1968): “Utterer's meaning and intentions” en Philosophical Review, número $78,147-177$.

(1981): "Presupposition and Conversational implicature" en Radical Pragmatics. P. Coole (ed.), New York: Academic Press, 183-198.

GUARDIA MASSÓ, P. (1976): La influencia del inglés en Barcelona: Ensayo de investigación léxica. Barcelona: Universitat de Barcelona.

GUERRERO RAMOS, G. (1995): Neologismos en el español actual. Madrid: Arco Libros.

GUTIÉRREZ ORDÓÑEZ, S. (1997): Comentario pragmático de textos publicitarios. Madrid: Arco Libros.

HALLIDAY, M.A.K. Y R. HASAN (1976): Cohesion in English. London: Longman. (1985): Language, context and text: aspects of language in a social-semiotic perspective. Oxford: Oxford University Press.

HARRIS, R.J. (1974): "Comprehension of pragmatic implications in advertising" en Journal Of Applied Psychology. Octubre 1977, volumen 62 (5), 603 - 608.

HOCKLEY, W. E. y S. LEWANDOWSKY (eds.) (1991): Relating Theory and Data: Essays on Human Memory in Honor of Benet B. Murdock. New Jersey: LEA, Hillsdale.

HOEY, M. (1983): On the Surface of Discourse. London: Allen \& Unwin.

HOPE, T. E. (1962): "Loan-words as Cultural and Lexical Symbols" en Archivum Linguisticum, XIV, 111-121.

(1963): "Loan-words as Cultural and Lexical Symbols (continued)" en Archivum Linguisticum, XV, 29-42.

(1980): "Interlanguage influences" en Trends in Romance Linguistics and Philology, Volume I: Romance Comparative and Historical Linguistics, R. Posner et al., Mouton, 241-287.

ISSER, W. (1976): El acto de Leer. Teoría del efecto estético. Madrid: Taurus, 1987.

JAKOBSON, R. (1975): Ensayos de lingüística general. Barcelona: Editorial Seix Barral. 
JEFKINS, F. (1985): Advertising. Plymouth: McDonald and Evans.

(1988): The secrets of successful direct response marketing. Oxford:

Heinemann.

JORDAN, M. P. (1984): Rhetoric of Everyday English Texts. London: Allen \& Unwin.

KACHRU, B.B. (1992): "The Other Side of English and the 1990's" en The Other Tongue. English Across Cultures. B.B. Kachru (ed.), Illinois: University of Illinois Press.

KAHANE, H. (1992): "American English: From a Colonial Substandard to a Prestige Language" en The Other Tongue. English Across Cultures. B.B. Kachru (ed.), Illinois: University of Illinois Press.

KIRKPATRICK, J. (1994): In defense of advertising: arguments from reason, ethical egoism and laisser-faire capitalism. Westport, Conneticut: Quorum.

KRESS, G. (1985): "Ideological Structures in Discourse" en Handbook of Discourse Analysis, Vol. IV, Discourse Analysis in Society. T. A. Van Dijk (ed.), London: Academic Press, 27-42.

LAKOFF, R. T. (1981): "Persuasive Discourse and Ordinary Conversation, with Examples from Advertising", en Georgetown University Round Table on Language and Linguistics. Washington D.C: Georgetown University Press, 25-42.

LAKOFF, G. y M. JOHNSON (1980): Metaphors we live by. Chicago: University of Chicago Press.

LANAO BERNALD, C. (1992): Aproximación al estudio del lenguaje publicitario en inglés: aspectos semánticos y pragmáticos. Universidad de Zaragoza: Servicio de publicaciones (microficha).

LANGHOLZ LEYMORE, V. (1975): Hidden Myth: Structure and Symbolism in Advertising. London: Heinemann Educational Books Ltd.

LAPESA, R. (1963): "La lengua desde hace cuarenta años" en Revista de Occidente, número 3, 193-208. 
(1966): "Kalatayood: Madariaga ha puesto el dedo en la llaga" en Revista de Occidente, número 12, 373-380.

(1977): “Tendencias y problemas actuales de la lengua española” en Comunicación y Lenguaje. R. Lapesa (coord.), Madrid: Karpos.

(1980): Historia de la lengua española. Madrid: Gredos (primera edición en 1942).

LASWELL, H. D. (1948): Propaganda Technique in the World War. Nueva York: Knopf.

LAVANDERA, B. (1990): Curso de lingüística para el análisis del discurso. Buenos Aires: Centro editor de América Latina.

LÁZARO CARRETER, F. (1987): "Los medios de comunicación y la lengua española” en Primera reunión de Academias de la lengua española sobre el lenguaje y los medios de comunicación. Octubre de 1985, Madrid, 29-44.

(1992): "El neologismo: planteamiento general y actitudes históricas" en El neologismo necesario. Madrid: Agencia EFE, 31-49.

LEECH, G. N. (1966): English in Advertising. A Linguistic Study of Advertising in Great Britain. London: Longman.

(1981): Semantics. Harmondsworth: Penguin.

(1983): The Principles of Pragmatics. London: Longman.

LEÓN, J. L. (1996): Influencia de la publicidad sobre las culturas nacionales. Barcelona: Ariel.

LEVINSON, S. C. (1983): Pragmatics. New York: Cambridge University Press.

LEWITT, T. (1983): “The Globalization of Markets" en Harvard Business Review, MayoJunio.

LINEROS QUINTERO, R. (1992): Estructuras lingüísticas de los discursos publicitarios en la prensa murciana. Tesina de licenciatura (microficha). 
LOMAS, C. (1996): El espectáculo del deseo. Usos y formas de la persuasión publicitaria. Barcelona: Ediciones Octaedro.

LOPE BLANCH, J. M. (1977): “Anglicismos en la norma linguiística culta de México” en Estudios sobre el español hablado en las principales ciudades de América. Lope Blanch (ed.), México: UNAM, 271-279.

LÓPEZ FRÍAS, F. (1983): "El lenguaje publicitario: Estudio Comparativo en Español e Inglés” en Revista de psicología, pedagogía y filosofía. Universitas Tarraconensis, 84-94.

LÓPEZ MORALES (1987): “Anglicismos léxicos en el habla culta de San Juan de Puerto Rico” en Lingüística Española Actual. Volumen IX, 285-303.

LÓPEZ QUINTAS, A. (1979): Estrategia del lenguaje y manipulación del hombre. Madrid: Narcea.

LORENTE, J. (1986): Casi todo lo que sé de publicidad. Barcelona: Ediciones Folio LORENZO, E. (1955): “El anglicismo en 1955” en El español de hoy, lengua en ebullición. Madrid: Gredos.

(1987): “Anglicismos en la prensa" en Primera reunión de Academias de la lengua española sobre el lenguaje y los medios de comunicación. Octubre de 1985, Madrid, 71-79.

(1995): “Anglicismos" en La lengua española, hoy. Manuel Seco et al. (coord.), Madrid: Fundación Juan March. (1996): Anglicismos hispánicos. Madrid: Editorial Gredos.

LUTZ ALESANDRINI, K. (1983): "Strategies That Influence Memory For Advertising Communications" en Information Processing Research in Advertising. Richard J. Harris (ed.), New Jersey: LEA.

LYONS, J. (1977): Semantics. Cambridge: Cambridge University Press.

MADARIAGA, S. de (1966): “VVamos a Kahlahtahyood?” en Revista de Occidente, número 36, 365-373. 
MAKIEL, Y. (1968): "Hispanic Philology" en Current Trends in Linguistics 4: Iberoamerican an Caribbean Linguistics, T.A. Sebeok (ed.), París: Mouton-The Hague, 180-181.

McDONALD, C. (1992): How Advertising Works: A Review of Current Thinking. Henley on Thames: N.T.C. Publications.

MEDINA LÓPEZ, J. (1991): "Los anglicismos: a propósito de los rótulos publicitarios” en Lexis, XV, número 1, 119-128.

(1994): "Anglicismos publicitarios: nuevos datos del español canario" en Revista Anual de la Sociedad Argentina de Lingüística, número 2, 7-18.

(1996): El anglicismo en el español actual. Madrid: Arco Libros.

(1997): Lenguas en contacto. Madrid: Arco Libros.

MEILLET, A. (1982): “Comment les mots changent de sens" en Linguistique historique et linguistique générale. Ginebra-París. Slatkine-Champion, 230-271.

MEY, J. L. (1993): Pragmatics. Oxford: Blackwell.

MILLS, S. (1995): Feminist Stylistics. London: Routledge.

MITCHELL, A. (1983): "Cognitive Processes Iniciated by Exposure to Advertising" en Information Processing Research in Advertising. Richard J. Harris (ed.) New Jersey: LEA.

MONCADA, A. (1995): España Americanizada. Madrid: Ediciones Temas de Hoy.

MOOIJ, M. K. (1991): Advertising Worldwide: concepts, theories and practice of international, multinational and global advertising. New York: Prentice Hall.

MORIYON MOJICA, C. (1994): Exégesis pragmática del discurso publicitario: ejemplos prácticos y selección bibliográfica. Valladolid: Instituto de Ciencias de la Educación, Universidad de Valladolid.

MYERS, G. (1994): Words in Ads. London: Arnold.

OGILVY, D. (1964): Confessions of an advertising man. New York: Dell Books. (1984): Ogilvy y la publicidad. Barcelona: Folio. 
(1995): Ogilvy on advertising. London: Prion (tercera edición).

PACKARD, V. (1975): The Hidden Persuaders. London: Penguin.

PENINOU, G. (1976): Semiótica de la publicidad. Barcelona: Gustavo Gili.

PENNY, R. (1991): A History of the Spanish Language. Cambridge: Cambridge University Press.

PEÑA MARÍN, C. (1990): La mujer en la publicidad. Madrid: Ministerio de Asuntos Sociales.

PERCY, L y A. G. WOODSIDE (eds.) (1983): Advertising and Consumer Psychology. Lexington: Lexington Books.

PERELMAN, Ch. y L. TYTELA (1989): Traité de l'argumentation. La nouvelle Rhétorique. Bruxelles: Editions Université de Bruxelles.

PÉREZ TORNERO, J.M. (1982): La semiótica de la publicidad. Análisis del lenguaje publicitario. Barcelona: Editorial Mitre.

PERICOT, J. (1987): Servirse de la imagen: un análisis pragmático de la imagen. Barcelona: Ariel.

PHILLIPSON, R. (1992): Linguistic Imperialism. Oxford: Oxford University Press.

(1999): "Review of English as a Global Language" en The European English Messenger. M. A. Kayman (ed.), Vol VII/1.

PRATT, C. (1972 - 1973): "El lenguaje de los medios de comunicación de masas: algunos aspectos" en Filología Moderna, números 46-47, 63-87.

(1980): El anglicismo en el español peninsular contemporáneo. Madrid:

Gredos.

(1994): “Colón, colonización, cocacolonización: 500 años de historia de la lengua española" en Actas del Primer Congreso Anglo-Americano. Tomo 1. Lingüística. Ralph Penny (ed.), Madrid: Castalia, 205-214. 
QUILIS, A. (1984): “Anglicismos en el español de Madrid” en Athlon, Satura Grammatica in honorem Francisci R. Andrados. Madrid: Gredos, 413-423.

RANDO, G. (1987): "Premessa" en Dizionario degli anglicismi nell'italiano postunitario. Florencia: Olschki.

REDDY, M. J. (1993): "The conduit metaphor: A case of frame conflict in our language about language" en Metaphor and Thought. A. Ortony (ed.), Cambridge: Cambridge University Press (segunda edición).

REY, J. (1996): Palabras para vender, palabras para soñar. Barcelona: Paidós.

REYES, G. (1990): La pragmática lingüística. Barcelona: Montesinos.

RIQUELME, J. (1998): Los anglicismos. Anglismos y anglicismos: huéspedes de la lengua. Editorial Aguaclara.

ROBERTS, M. L. y P.D. BERGER (1989): Direct Marketing Management. New Jersey: Prentince-Hall.

RODRÍGUEZ GONZÁLEZ, F. (1994): “Anglicismos en el argot de la droga” en Atlantis. Revista de la asociación española de estudios anglo-norteamericanos. Volumen XVI, números 1 y 2, noviembre, Tenerife, 179-216.

(1996): "Functions of Anglicisms in Contemporary Spanish" en Cahiers de Lexicologie, número 68, 107-128.

(1999): “Anglicisms in Contemporary Spanish, An Overview" en Atlantis. Revista de la asociación española de estudios anglonorteamericanos. Vol. XXI, números 1 y 2, junio-diciembre 1999, 103-139.

ROTZOLL, K. B. (1978): What Factors Affect Response to Advertisements? Urbana: University of Illinois, Department of Advertising. (1985): “Advertisements" en Discourse and Communication. Van Dijk (ed.) Berlin: Walter de Gruyter.

ROTZOLL, K. B. y J. E. HAEFNER (1990): Advertising in Contemporary Society: Perspectives towards Understanding. Cincinatti: South Western Publishing. 
SÁNCHEZ CORRAL, L. (1991): Retórica y sintaxis de la publicidad. Itinerarios de la persuasión. Universidad de Murcia: Servicio de publicaciones.

SÁNCHEZ GUZMÁN, J. R. (1982): Breve historia de la publicidad. Madrid: Ciencia 3.

SÁNCHEZ MACARRO, A. (1993): "La invasión del anglicismo en el español contemporáneo" en Actas del Simposio sobre el español de España y el español de América.

R. Morant et al. (eds), Valencia: Universidad de Valencia/University of Virginia,19-34.

SCHLIEBEN-LANGE, B. (1975): Pragmática lingüística. Madrid: Editorial Gredos.

SEARLE, J. R. (1969): Speech Acts. Cambridge: Cambridge University Press.

(1979): Expression and meaning: studies in the theory of speech acts.

Cambridge: Cambridge University Press.

SECO, M. (1977): "El léxico de hoy" en Comunicación y lenguaje. R. Lapesa (coord.), Madrid: Karpos, 183-201.

SHANNON, C. E. y W. Weaver (1981): Teoría matemática de la comunicación. Madrid: Ediciones Forja.

SHIMP, T. A. (1993): Promotion Management and Marketing Communication. Orlando: The Dryden Press.

SPERBER, D. y L. HIRSCHFELD (1999): "Culture, Cognition and Evolution" en MIT Encyclopedia of the Cognitive Sciences. Robert Wilson et al. (eds.), Massachusetts: MIT Press. cxi-cxxxii.

SPERBER, D. y D. WILSON (1986): Relevance. Communication and Cognition. Oxford: Blackwell.

(1990): "Retórica y pertinencia" en Revista de Occidente, número 115, Diciembre 1990, 5-25.

(1995): Relevance. Communication and Cognition. Oxford:

Blackwell (segunda edición).

(1996): "Fodor's Frame Problem and Relevance Theory" en

Behavioral and Brain Sciences, 19, 530-532. 
STONE, H. (1957): "Los anglicismos en España y su papel en la lengua oral" en Revista de filología Española, XLI, 141-160.

STREVENS, P. (1992): "English as an International Language: Directions in the 1990s" en The Other Tongue. English Across Cultures B.B. Kachru (ed.), Illinois: University of Illinois Press.

STUBBS, M. (1983): Discourse Analysis: the sociolinguistic analysis of natural language. Oxford: Blackwell.

SWATCH COMPANY (1999): Swatch Basics. Facts and Figures from the World of Swatch. Biel: Swatch Ltd.

TALBOT, M y J. L. MEY (1988): "Computation and the Soul” en Journal of Pragmatics, $12,743-789$.

TANAKA, K. (1994): Advertising Language: a pragmatic approach to advertisements in Britain and Japan. London: Routledge.

TANNEN, D. (ed.) (1982): Analyzing discourse: Text and talk. Washington, D. C: Georgetown University Press.

VALDÉS RODRÍGUEZ, C. (1998): "Parámetros descriptivos en la traducción de textos publicitarios" en Livius, número 12, 193-202.

VAN DIJK, T.A. (1977): Text and Context. Explorations in the semantics and pragmatics of discourse. London: Longman. (1980): Macrostructures: An Interdisciplinary Study of Global Structures in Discourse, Interaction and Cognition. New Jersey: Lawrence Erlbaum Associates. (1981): Studies in the Pragmatics of Discourse.The Hague: Moulton. (1985): Handbook of Discourse Analysis. 4 Vols. London: Academic Press.

VAN DIJK, T.A. y W. KINTSCH (1983): Strategies of Discourse Comprehension. London/New York: Academic Press. 
VÁZQUEZ, I. y S. ALDEA (1991): Estrategia y manipulación del lenguaje: análisis pragmático del discurso publi-propagandístico. Universidad de Zaragoza: Secretariado de Publicaciones.

VESTERGAARD, T. y K. SCHRØDER (1985): The language of advertising. Oxford: Blackwell.

VIERECK, W. (1988): "The Political and Technological Impact of the United States of America in the 1950's and Early 1960's as Reflected in Several European Languages" en Folia Lingüística, XXII, 1-2, Berlin: Mouton-de Gruyter, 141-152.

WALKER, R. C. S. (1989): "Review of Relevance" en Mind and Language, número 4, 151159.

WEBB YOUNG, J. (1989): Cómo llegar a ser un buen publicista. New York: McGraw-Hill.

WILLIAMSON, J. (1978): Decoding Advertisements: Ideology and Meaning in Advertising. London: Marion Boyars Publishers.

WILSON, D. (1998): "Recent approaches to bridging: truth, coherence, relevance" ponencia presentada en el I Simposio Internacional de Análisis del Discurso, 20 y 22 de abril, Universidad Complutense de Madrid.

WILSON, D y D. SPERBER (1986a): "Inference and implicature in utterance interpretation" en Reasoning and Discourse Processes. T. Myers, K. Brown \& B. McGonigle (eds.), London: Academic Press, 241-263.

(1986b): "Inference and implicature" en Meaning and Interpretation. Ch. Travis (ed.), Oxford: Blackwell.

WOLF, M. (1987): Research on mass media communication. Harmondsworth: Penguin.

YOUNG, R., A. BECKER y K. PIKE (1970): Rhetoric: Discovery and Change. New York: Harcourt, Brace \& World. 


\section{DICCIONARIOS Y ENCICLOPEDIAS}

Enciclopedia Temática Planeta: Botánica, Zoología, Ecología editada por Planeta en el año 1974. (Barcelona)

ALFARO, R. J. (1970): Diccionario de Anglicismos, Madrid: Gredos.

DUBOIS, J. et al. (1983): Diccionario de lingüística. Madrid: Alianza Editorial (primera edición en 1973).

GUTIÉRREZ CUADRADO, J. (dir.) (1996): Diccionario Salamanca de la lengua española. Madrid: Santillana. Coedición con la Universidad de Salamanca.

LÁZARO CARRETER, F. (1973) Diccionario de términos filológicos. Madrid: Gredos (primera edición en 1955).

LONGMAN (1987): Longman Dictionary Of Contemporary English. Harlow: Longman Group (segunda edición).

MOLINER, M. (1989): Diccionario de uso del español. Madrid: Editorial Gredos. (primera edición en 1975).

REAL ACADEMIA ESPAÑOLA (1992): Diccionario de la lengua española. Vigésima primera edición. 